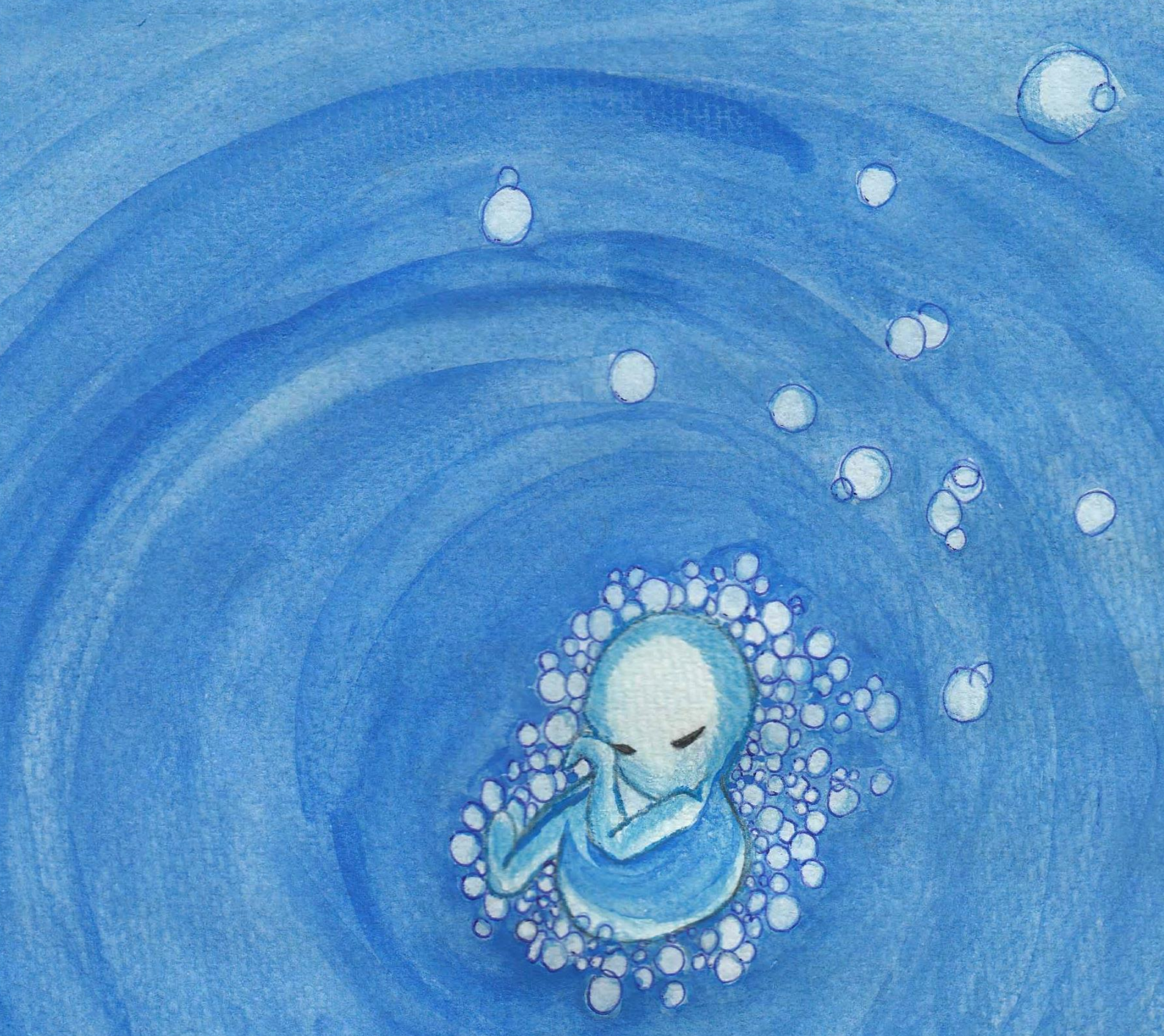

Anaerobic Treatment of Municipal Wastewater in a UASB-Digester System

Temperature effect on system performance, hydrolysis and methanogenesis

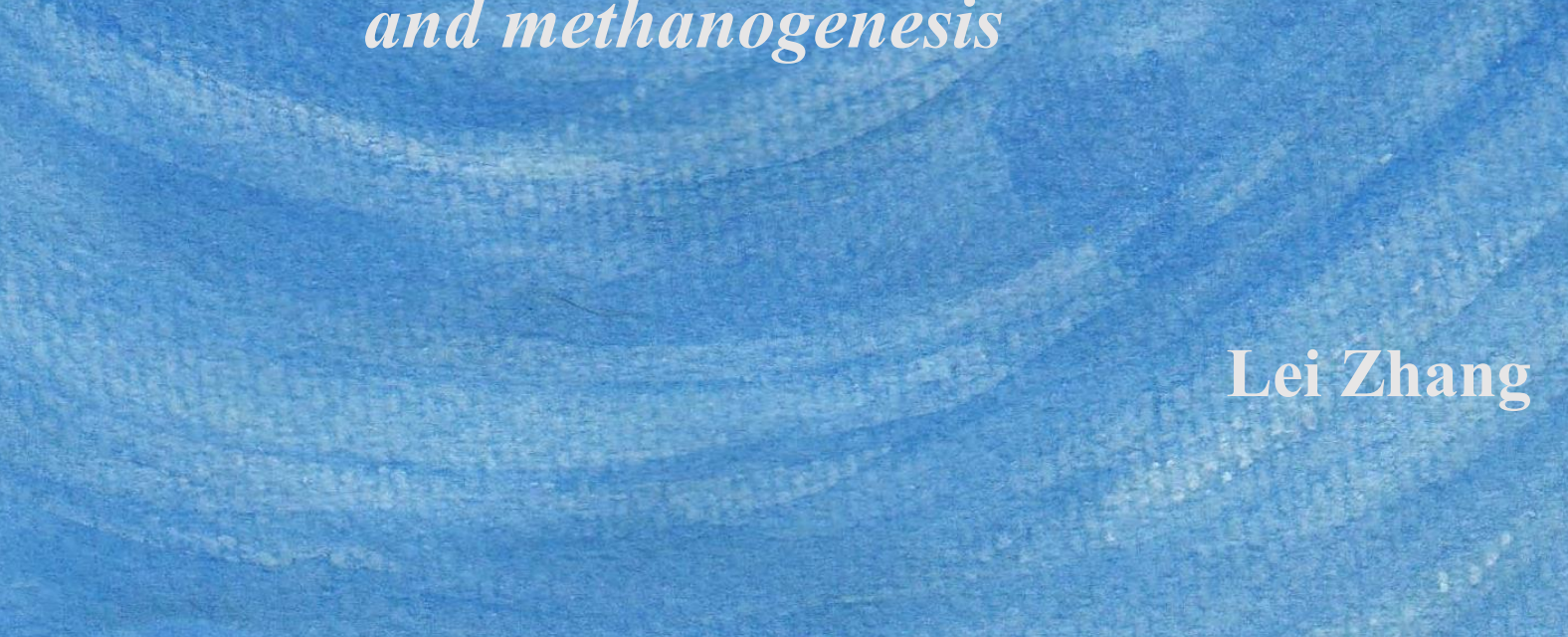




\section{Anaerobic Treatment of Municipal Wastewater in a UASB-Digester System}

Temperature effect on system performance, hydrolysis and methanogenesis 


\section{Thesis committee}

\section{Promotors}

Prof. Dr G. Zeeman

Personal chair at the sub-department of Environmental Technology

Wageningen University

Prof. Dr H.H.M. Rijnaarts

Professor of Environmental Technology

Wageningen University

\section{Co-promotor}

Dr T.L.G. Hendrickx

Process Specialist

Paques bv, Balk

\section{Other members}

Dr M.H. Zandvoort, Researcher Waternet, Almere

Prof. Dr J.B. van Lier, Delft University of Technology

Prof. Dr V. O’Flaherty, NUI Galway, Ireland

Prof. Dr G. Eggink, Wageningen University

This research was conducted under the auspices of the Graduate School SENSE (Socio-Economic and Natural Sciences of the Environment) 


\title{
Anaerobic Treatment of Municipal Wastewater in a UASB-Digester System \\ Temperature effect on system performance, hydrolysis and methanogenesis
}

\section{Lei Zhang}

\author{
Thesis \\ submitted in fulfilment of the requirements for the degree of doctor \\ at Wageningen University \\ by the authority of the Rector Magnificus \\ Prof. Dr A.P.J. Mol, \\ in the presence of the \\ Thesis Committee appointed by the Academic Board \\ to be defended in public \\ on Wednesday 23 November 2016 \\ at 1:30 p.m. in the Aula.
}




\section{Lei Zhang}

Anaerobic Treatment of Municipal Wastewater in a UASB-Digester System

Temperature effect on system performance, hydrolysis and methanogenesis,

169 Pages.

$\mathrm{PhD}$ thesis, Wageningen University, Wageningen, NL (2016)

With references, with summary in English

ISBN: 978-94-6257-979-8

DOI: $\quad 10.18174 / 393388$ 
To my wife Xin and son HaoYi 


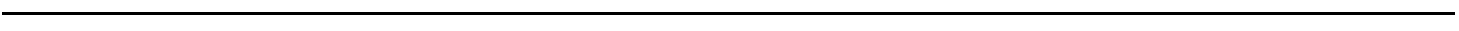


Abstract 11

\section{Introduction} 15

1.1 Introduction 17

1.2 Water scarcity 17

1.3 Conventional municipal wastewater treatment 20

1.4 Anaerobic wastewater treatment ___ 21

1.4.1 Anaerobic conversion steps __ 21

1.4.2 Effects of low temperature on anaerobic conversion __ 22

1.4.3 Different types of anaerobic reactors _ 23

1.5 Anaerobic municipal wastewater treatment in tropical areas ___ 25

1.6 Anaerobic treatment of low temperature wastewater ___ 27

1.6.1 Single anaerobic reactors__ 27

1.6.2 Combined anaerobic reactors _ 30

1.7 Scope of this thesis ___ 34

2 Effects of sludge recirculation rate and Sludge transfer point on a UASB-digester system to treat domestic sewage at $15{ }^{\circ} \mathrm{C}$

2.1 Introduction ___ _ _ _ _ 39

2.2 Method and materials ___ 40

2.2.1 Inoculum and sewage

2.2.2 A UASB-digester system _ 40

2.2.3 Batch experiment _ 42

2.2.4 Analysis__ 42

2.3 Results and discussion ___ 43

2.3.1 Effects of sludge recirculation rate __ 43

2.3.2 Effects of HUST__ 47

2.4 Conclusions ___ 49

3 Co-digestion to support low temperature anaerobic pretreatment of municipal sewage in a UASB-digester ___ 51

3.1 Introduction ___ 53

3.2 Materials and methods ___ 54

3.2.1 UASB-digester with co-digestion __ 54

3.2.2 Sewage _ 55

3.2.3 Specific methanogenic activity (SMA) 56

3.2.4 Biological methane potential (BMP) of municipal sewage __ 56

3.2.5 Analyses _ 56

3.3 Results and discussion ___ 57

3.3.1 Characteristics of sewage COD __ 57

3.3.2 Sewage COD removal efficiency ___ 58 
3.3.3 Methanogenic capacity UASB 60

3.3.4 Methane production __ 61

3.3.5 General Discussion___ 64

3.4 Conclusions

4 Anaerobic treatment of domestic wastewater in a UASB-digester demonstrated at a temperature of $10^{\circ} \mathrm{C}$

4.1 Introduction ______________ 69

4.2 Materials and method ___ 70

4.2.1 Experiment set-up — 70

4.2.2 Batch experiments _ 72

4.2.3 Microbial community analysis __ 73

4.2.4 Analytical methods__ 73

4.2.5 Calculation _ 75

4.3 Results __________________ 76

4.3.1 COD removal___ 76

4.3.2 Methane production rate___ 79

4.3.3 COD mass balance __ 81

4.3.4 Methanogenic capacity ___ 81

4.3.5 Microbial community analysis ___ 83

4.4 Discussion____ 83

4.5 Conclusions ____________________ 88

5 Hydrolysis rate constants at $10-25^{\circ} \mathrm{C}$ can be more than doubled by a short anaerobic pre-hydrolysis at $35^{\circ} \mathrm{C}$

5.1 Introduction ___ _ _ 93

5.2 Material and Methods_____ 94

5.2.1 Inoculum___ 94

5.2.2 Determination of hydrolysis rate constants at constant temperatures ___ 95

5.2.3 Effects of a short pre-hydrolysis at $35^{\circ} \mathrm{C}$ on low temperature hydrolysis ___ 95

5.2.4 Hydrolytic activity of supernatant phase at $10-35^{\circ} \mathrm{C} \_97$

5.2.5 Analysis__ 98

5.2.6 Calculation _ 98

5.3 Results _ 100

5.3.1 Effects of pre-hydrolysis at $35^{\circ} \mathrm{C}$ on low temperature hydrolysis of cellulose __ 100

5.3.2 Effects of pre-hydrolysis at $35^{\circ} \mathrm{C}$ on low temperature hydrolysis of tributyrin __ 101

5.3.3 Hydrolytic activity of supernatant phase at $10-35^{\circ} \mathrm{C} \_105$

5.3.4 Discussion__ 105

5.4 Conclusions ___ 109

6 Effects of temperature and temperature shocks on specific methanogenic activity and affinity for acetate of sludge exposed to varying temperature conditions (10- 
6.1 Introduction 113

6.2 Materials and methods 114

6.2.1 Source of inoculum 114

6.2.2 Affinity of the digester sludge at $10-35^{\circ} \mathrm{C}$ 115

6.2.3 Effects of cold temperature shock on SMA 115

6.2.4 Activity monitoring 115

6.2.5 Data interpretation and calculations 116

6.3 Results 117

6.3.1 Effects of a sudden temperature drop on SMA 117

6.3.2 Effects of low temperature on affinity for acetate utilization 118

6.3.3 Discussion 120

6.4 Conclusions 122

7 General Discussion 125

7.1 Introduction 126

7.2 Operation of a UASB-digester treating municipal wastewater 127

7.2.1 Sludge recirculation rate and the sludge transfer point 127

7.2.2 Co-digestion 128

7.2.3 Operation at temperatures decreasing from 20 to $10^{\circ} \mathrm{C}$ 128

7.2.4 Effect of temperature fluctuation on methanogenesis

7.2.5 Short-term pre-hydrolysis at mesophilic condition enhances low temperature hydrolysis 130

\subsection{Outlook}

131

7.3.1 New municipal wastewater treatment

7.3.2 Costs 132

7.3.3 Recommendations for further research

Summary

Literature

Annex

Publications 159

Acknowledgement 161 


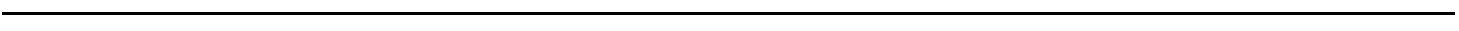


Abstract 


\begin{abstract}
A novel treatment chain for low strength domestic sewage includes low temperature anaerobic treatment as the main process. It can improve the energy efficiency of sewage treatment compared with conventional aerobic sewage treatment. A combination of an Upflow Anaerobic Sludge Blanket reactor and a sludge digester, a UASB-digester system, was proven to be one of the successful anaerobic systems to challenge temperatures as low as $10^{\circ} \mathrm{C}$ and organic matter concentrations in the range of 382 and $1054 \mathrm{mg}$ chemical oxygen demand (COD)/l. The UASB is operated at low sewage temperature $\left(10^{\circ} \mathrm{C}\right)$ and high loading rate. The produced non-stabilised sludge in the UASB is recirculated over the mesophilic digester $\left(35^{\circ} \mathrm{C}\right)$ to convert organic solids to methane gas and produce anaerobic biomass fed back into the UASB reactor, where it converts dissolved COD at the low temperature of the waste water.
\end{abstract}

The effect of sludge recirculation rate and sludge transfer point on the performance of a UASB-digester treating domestic sewage at $15{ }^{\circ} \mathrm{C}$ was studied in this research. The results show increased total COD removal efficiency when increasing the sludge recirculation rate from $1 \%$ to $2.6 \%$ of the influent flow rate. Methane gas production increases with the sludge recirculation rate, in the range of 1 to $12.5 \%$ of the influent flow rate. A higher sludge transfer point results in an increased suspended COD removal efficiency and a higher VSS concentration of the UASB sludge bed.

Co-digestion was applied for improving soluble COD removal efficiency of a UASBdigester system, operated at low temperatures and treating domestic sewage with a high dissolved/suspended COD ratio. Glucose was chosen as a model co-substrate and added to the sludge digester to produce additional methanogenic biomass, which was continuously recycled to inoculate the UASB reactor. Methane production in the UASB reactor almost doubles and soluble COD removal efficiency equals the biodegradability of the influent dissolved COD, due to a twofold increase in methanogenic capacity, when applying co-digestion $16 \%$ of influent organic loading rate. Therefore, codigestion is a suitable approach to support a UASB-digester for treatment of low temperature domestic sewage.

A pilot scale UASB-digester $(130+50 \mathrm{~L})$ was studied to treat domestic wastewater at temperatures of $10-20^{\circ} \mathrm{C}$ at an $\mathrm{HRT}$ of $6 \mathrm{~h}$ in the UASB reactor and $15 \mathrm{~h}$ in the digester. The results show a stable COD removal efficiency of $60 \pm 4.6 \%$ during the operation at 12.5 to $20^{\circ} \mathrm{C}$. COD removal efficiency decreases to $51.5 \pm 5.5 \%$ at $10^{\circ} \mathrm{C}$. The decreased COD removal efficiency is attributed to an increased influent COD load, leading to insufficient methanogenic capacity of the UASB reactor at such low temperature. Suspended COD removal efficiency was $76.0 \pm 9.1 \%$ at $10-20^{\circ} \mathrm{C}$. The effluent COD concentration is $90 \pm 23 \mathrm{mg} / \mathrm{L}$ at temperatures between 12.5 and $20^{\circ} \mathrm{C}$, while soluble COD removal efficiency fluctuates due to variation in the influent COD concentration. $80 \%$ of the influent biodegradable COD is recovered as methane gas (including dissolved methane). 
Low temperature $\left(10-25^{\circ} \mathrm{C}\right)$ hydrolysis after applying a short pre-hydrolysis at $35^{\circ} \mathrm{C}$ was studied compared with those without the pre-hydrolysis. Batch experiments were executed using cellulose and tributyrin as model substrates for carbohydrates and lipids. Low temperature anaerobic hydrolysis rate constants increase by a factor 1.5 - 10 after applying a short anaerobic pre-hydrolysis at $35^{\circ} \mathrm{C}$. The hydrolytic activity of the supernatant collected from the digestate after batch digestion of cellulose and tributyrin at $35^{\circ} \mathrm{C}$ was higher than that of the supernatants collected from the low temperature ( $\leq$ $25^{\circ} \mathrm{C}$ ) digestates. The observed hydrolysis in the UASB of a UASB-digester system, treating domestic sewage at low temperatures $\left(10-20^{\circ} \mathrm{C}\right)$ is in line with the elevated hydrolytic activity of mesophilic supernatant.

Effects of temperature and temperature shocks on specific methanogenic activity (SMA), and acetate affinity of the digester sludge were studied. Digester sludge from a UASB $\left(12.5^{\circ} \mathrm{C}\right)$-digester $\left(35^{\circ} \mathrm{C}\right)$ system, was fed with acetate at constant temperatures of $10-35^{\circ} \mathrm{C}$ and at varying temperatures from $35^{\circ} \mathrm{C}$ to 25 , to 15 to $10^{\circ} \mathrm{C}$. The results show no lag phase in methane production rate when applying temperature shocks of $35^{\circ} \mathrm{C}$ to 25,15 , and $10^{\circ} \mathrm{C}$. The temperature dependency of the SMA of the digester sludge after the temperature shocks was similar to the one at constant temperatures. Acetate affinity of the digester sludge was high at the applied temperatures $\left(10-35^{\circ} \mathrm{C}\right)$. Latter is consistent with the finding of no VFA in the effluent of the UASB-digester, treating low strength, and low temperature $\left(12.5^{\circ} \mathrm{C}\right)$ domestic wastewater.

The UASB-digester system to treat low strength, low temperature domestic sewage was provided with a proof-of-principle, and its essential underlying anaerobic processes were sufficiently elucidated to make the technology ready for further scaling up and demonstration in practice.

Keywords: UASB reactor, municipal wastewater treatment, low temperature, digester, pre-hydrolysis, temperature shocks, water scarcity, affinity, UASB-digester, hydrolysis rate constant, half-saturated constant, co-digestion 


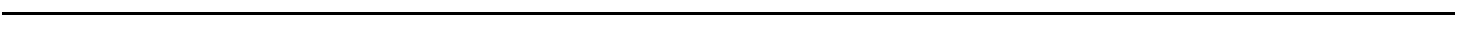


1

Introduction 
List of Abbreviations for introduction:

ABRs: Anaerobic baffled reactors

AF: anaerobic filter

AH: anaerobic hybrid reactor

AMBRs: anaerobic migrating blanket reactors

ANAMMOX: anaerobic ammonia oxidation

AnMBRs: Anaerobic membrane reactors

BOD: biological oxygen demand

CAPEX: capital expenditures

COD: chemical oxygen demand

$\mathrm{COD}_{\mathrm{t}}$ : total COD

COD ss: suspended COD

$\mathrm{COD}_{\text {sol: }}$ soluble $\mathrm{COD}$

CSTRs: Continuous stirred tank reactors

DAMO: denitrification anaerobic methane oxidation

EGSB: Expanded granular sludge bed

GHG: Greenhouse Gas

HRT: hydraulic retention time

HUSB: hydrolytic upflow sludge bed

$\mathrm{K}_{\mathrm{s}}$ : half-saturation velocity constant

OPEX: operational expenditures

SAMBR: submerged anaerobic membrane bioreactor

SRT: sludge retention time

TSS: total suspended solids

UASB: upflow anaerobic sludge blanket 


\subsection{Introduction}

The world will increasingly experience water scarcity due to increasing global population, rising water demand, fast urbanization and climate change. In addition to problems in quantity, the quality of fresh water resources is main issue especially in emerging and developing economies (Zinia \& Kroeze, 2015). To avoid water resource pollution, municipal wastewater, as one of the main pollution sources, must be treated before discharged into the receiving surface water. However, in developing countries not all the cities have yet adequate wastewater treatment plants, and are generally in need for low-cost and effective solutions. The world-wide numerously applied activated sludge process can provide good effluent quality but consumes high amounts of energy and is characterized by high operational cost (Verstraete et al., 2009). Anaerobic municipal wastewater treatment can be an alternative to reduce energy consumption and operational cost (Siegrist et al., 2008), but is applicable especially at higher temperature climates in tropical countries. Low temperature is still a challenge for anaerobic wastewater treatment of municipal wastewater because of low hydrolysis rate of the influent organic matter and the low methanogenic activity, converting hydrolyzed material into biogas. Many different kinds of anaerobic reactors have been studied to deal with these problems caused by low temperatures. Among these anaerobic reactors, an upflow anaerobic sludge blanket (UASB) reactor-digester is a promising system as it can provide relatively high chemical oxygen demand (COD) removal efficiencies and energy production in the form of methane. Furthermore, it provides stabilized excess sludge compared with other two phase systems like anaerobic filter (AF) - anaerobic hybrid (AH) reactor (AF-AH) or hydrolytic upflow sludge bed (HUSB) - UASB reactor (HUSB-UASB) (or expanded granular sludge bed (EGSB) instead of UASB). In this chapter, an introduction is given into the background and motivation for conducting the research to develop an energy friendly municipal wastewater treatment plant for moderate climate regions, specifically a UASB-digester system.

\subsection{Water scarcity}

The scarcity of freshwater is increasing due to rising water demands and a changing climate, which is considered as a major risk for the global economy, food security, sanitation and drinking water availability for the society (Garrote et al., 2016). Countries whose renewable water supply cannot sustain $1700 \mathrm{~m}^{3}$ of renewable water resources per capita per year are considered as water stressed. This demarking amount of renewable water resources is based on estimates of water requirements in households and agricultural, industrial and energy sectors, and the needs of the environment (Shiklomanov, 2000). When availability is lower than $1000 \mathrm{~m}^{3} \mathrm{p}^{-1} \mathrm{y}^{-1}$, a country experiences water scarcity and lower than $500 \mathrm{~m}^{3} \mathrm{p}^{-1} \mathrm{y}^{-1}$, absolute scarcity. Countries, particularly Central and West Asia and North Africa, the arid areas of the world, are already close to, or below the $1000 \mathrm{~m}^{3} \mathrm{p}^{-1} \mathrm{y}^{-1}$ threshold as shown in Fig.1.1. The results of global water scarcity analyses show that up to two thirds of the world population will 


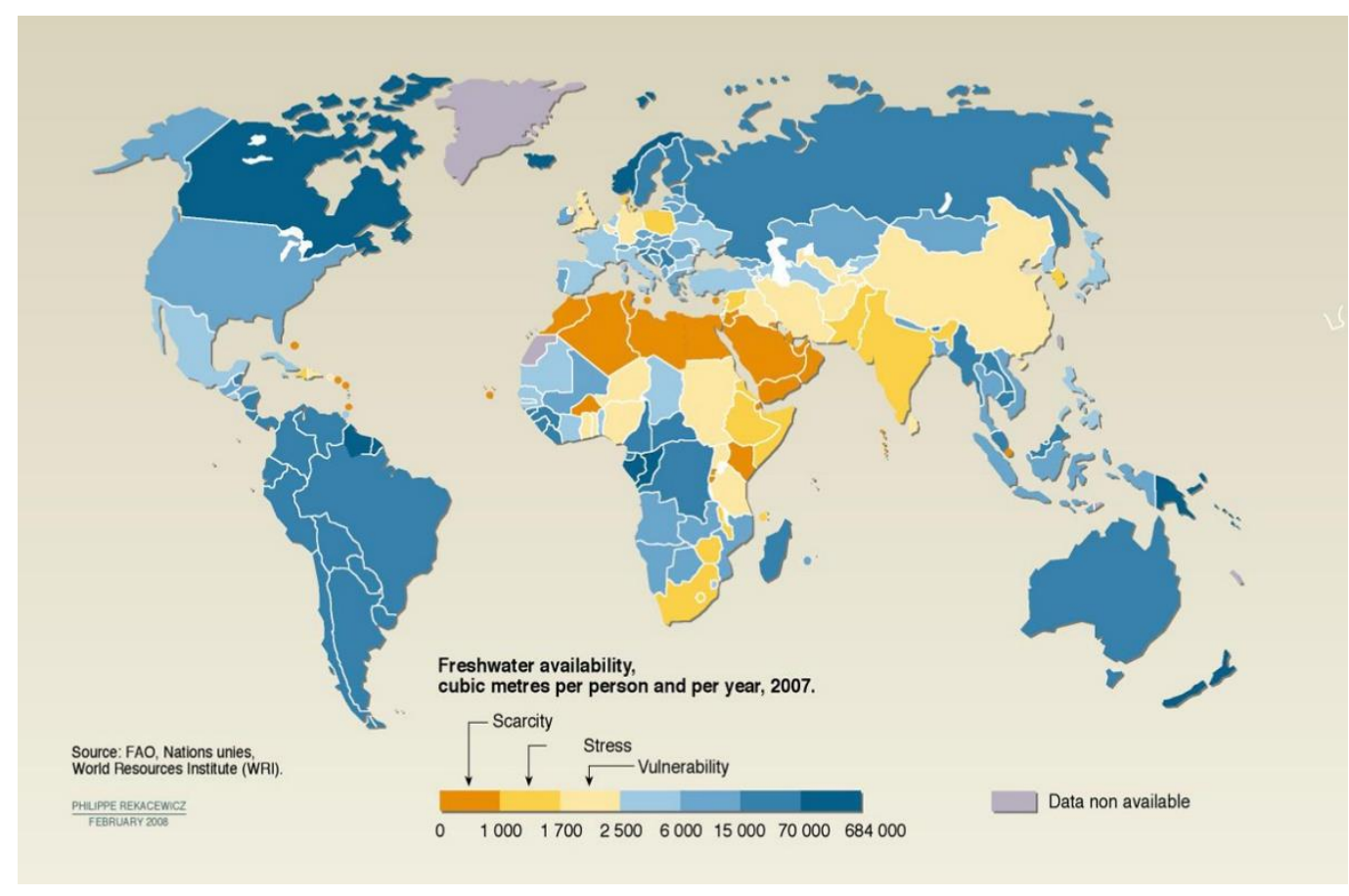

Fig.1.1 Freshwater availability, cubic meters per person and per year, 2007

experience water scarcity over the next decades (Springer \& Duchin, 2014).

Wallace (2000) reported that people had less than $1000 \mathrm{~m}^{3} \mathrm{p}^{-1} \mathrm{y}^{-1}$ in the North-Africa belt (from Morocco to Egypt and including Sudan), and between $1000-2000 \mathrm{~m}^{3} \mathrm{p}^{-1} \mathrm{y}^{-1}$ in the Middle East and Southern Africa (Rijsberman, 2006). People in Egypt have less than $500-1000 \mathrm{~m}^{3} \mathrm{p}^{-1} \mathrm{y}^{-1}$ by 2025 . Wallace (2000) estimates that the water availability of entire North, East and South Africa, and the Middle East, will drop below $1000 \mathrm{~m}^{3} \mathrm{p}^{-1} \mathrm{y}^{-}$ ${ }^{1}$ before 2050. West Africa and large parts of South and South-east Asia would range between 1000-2000 $\mathrm{m}^{3} \mathrm{p}^{-1} \mathrm{y}^{-1}$.

Millions of people are living in water-stressed areas. As an example, farmers near Sana'a in Yemen have deepened their wells by 50 meters over the past 12 years, while the amount of useable water only remains one third of past water extraction yields (Human Development Report 2006). The future of many of the world's water supplies is undoubtedly a story of increasing stress as shown in Fig.1.2. Increased standard of living in developing countries would result in higher per capita water consumption (Ahmed et al., 2014). The world's population is expected to increase to about nine billion by 2050. Most of the three billion additional people will live in the developing or emerging economy countries where water resources are already under stress, including China. 


\section{Water Stress by Country: 2040}

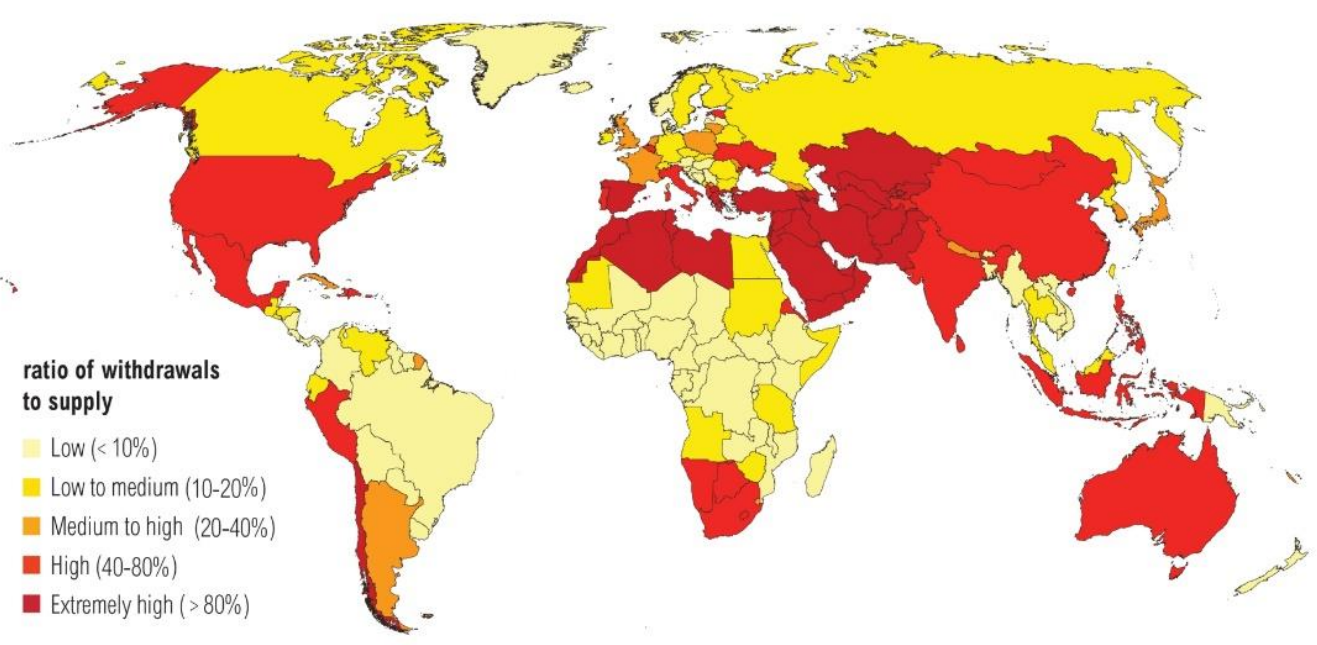

NOTE: Projections are based on a business-as-usual scenario using SSP2 and RCP8.5.

Fig.1.2 Water stress indicator in major basins of the world

China's population is approximately 1.3 billion, which accounts for $20 \%$ of the world's total population (Zhang et al., 2016c). Yet China only has $6.5 \%$ of the world's total renewable freshwater resources. With its large population, China's water availability is estimated at about $2100 \mathrm{~m}^{3}$ per capita per year, which is approximately $25 \%$ of the world average (Arnell, 2004). China's urban population is more than doubled in less than 25 years and accounted for $43 \%$ of the total population in 2005 . The large population and rapid urbanization impose heavy pressure on infrastructure development and public services such as drinking water supply and wastewater treatment.

China has been facing increasingly severe water scarcity, particularly in the arid northern part of the country (Zeng et al., 2012). China's water scarcity is characterized by insufficient quantities and poor drinking water quality (Zhou et al., 2014). The problems have negative effects on society and the environment. Rapid economic development, population growth and urbanization trigger a conflict between water supply and demand. Water pollution is a serious problem for water resource protection in China, as well as many other emerging economies and developing countries. Water pollution has extended from point source to non-point source, from fresh water to coastal water, and from surface water to groundwater. Therefore, it is crucial to pay attention to improved wastewater treatment, as an element in mitigating deterioration of water resources quality. 


\subsection{Conventional municipal wastewater treatment}

All over the world, more than one billion people do not have access to safe sanitation and drinking water. $80 \%$ of diseases and $30 \%$ of deaths are water-related in developing countries as reported in the Human Development Report, United Nations Development Program (De Vries \& Lopez, 2013). Industrial and agricultural activities account for a major portion of water pollution, but municipal wastewater, containing urine, feces, kitchen and washing wastes, is the main cause of water related human health problems. Municipal wastewater treatment is therefore a priority to improve human health.

Conventional wastewater treatment consists of the following elements: screening and primary sedimentation followed by an aerobic activated sludge process to remove organic matter and compounds containing inorganic nitrogen and phosphorus. At larger treatment plants, the activated sludge process is often complemented with a sludge digestion reactor where part of the energy in the organic waste material is recovered as biogas. Energy produced in the form of methane in such an anaerobic sludge digester can compensate a quarter to half of the total energy consumption in a conventional wastewater treatment plant (EPA, 2006). The effluent of the wastewater treatment plant is discharged into surface waters when its quality meets local or national standard.

Large fractions of dissolved organic materials are converted to biomass, consuming considerable energy, which still requires further treatment. As a result, the energy consumption of a conventional wastewater treatment plant due to aeration is high, 0.6 $\mathrm{kWh}$ per $\mathrm{m}^{3}$ of wastewater, which accounts for about half of the total energy consumption (McCarty et al., 2011). Electrical energy consumption of wastewater treatment accounts for about 3\% of the total electricity load in America, which is similar to other developed countries (EPA, 2006). Due to concerns about climate change, fossil fuel consumption and increasing energy costs, efforts should be made to establish a novel wastewater treatment that is energy efficient and is more sustainable from an energy saving point of view. Therefore, innovations in wastewater treatment have been aimed at reducing costs, saving energy, and lowering the environmental impact.

Municipal wastewater with an COD concentration of 400-500 mg/L contains a potential chemical energy of 1.5-1.9 $\mathrm{kWh}$ per $\mathrm{m}^{3}$ of wastewater (Owen, 1982). If more of the energy potential in wastewater can be recovered and be used for the treatment itself, then a wastewater treatment plant that is a net energy producer rather than a consumer might be achieved. This chapter will provide information to aid in understanding and interpreting anaerobic wastewater treatment, which is much more energy and operational cost friendlier than conventional aerobic wastewater treatment. 


\subsection{Anaerobic wastewater treatment}

\subsubsection{Anaerobic conversion steps}

During anaerobic conversion of complex substrates such as polysaccharides, proteins and lipids, a complex microbial community consisting of many interacting microbial species is involved. The anaerobic digestion mainly includes 4 steps: hydrolysis, acidogenesis, acetogenesis and methanogenesis (McKeown et al., 2012). Hydrolysis and methanogenesis are considered as rate limiting steps depending on conditions like substrate types, temperature, $\mathrm{pH}$ and sludge retention time (SRT) etc.. Therewith, the study focuses only on hydrolysis and methanogenesis.

\subsubsection{Hydrolysis}

Hydrolysis is the first step in the anaerobic treatment of complex wastewater and considered as the rate limiting step (Hendriks \& Zeeman, 2008; Lettinga et al., 2001; Pavlostathis \& Giraldo-Gomez, 1991b). For instance, the anaerobic hydrolysis rate of cellulose is low due to the insolubility and heterogeneity of cellulose (Hendriks \& Zeeman, 2008). Anaerobic hydrolytic bacteria utilize a unique extracellular multienzyme complex, called cellulosome for this recalcitrant substrate (Schwarz, 2001). These multi-enzyme complexes make a bridge between the cell envelope and the substrate, which allows the cells to get close to the cellulose. However, many crucial details of cellulose hydrolysis are still unknown.

The hydrolysis of organic solids in anaerobic digestion can be described by first order kinetics (Batstone et al., 2002; Vavilin et al., 1996). Methane will be the main product if hydrolysis is the slowest step compared to acidification, acetogenenesis and methanogenesis (Veeken \& Hamelers, 1999). The hydrolysis rate constant can differ due to various experimental conditions such as inoculum source, ratio of biomass and substrate, and available surface of substrate (Sanders et al., 2000; Vavilin et al., 2008).

\subsubsection{Methanogenesis}

Methanogenesis is the last step in anaerobic digestion of organic matter. Acetate is a major product of the fermentation of organic matter and about $70 \%$ methanogenesis is through the acetate route under mesophilic conditions, and the rest is through $\mathrm{H}_{2} / \mathrm{CO}_{2}$ (Aiyuk et al., 2006). Methanogenesis with a high affinity for acetate, is important when treating municipal wastewater with a relatively low COD concentration, at high loading rates. The affinity can be presented by the half-saturation velocity constant $\left(\mathrm{K}_{\mathrm{s}}\right)$ in the Monod equation (Arnaldos et al., 2015). Varying conditions in $\mathrm{K}_{\mathrm{s}}$ quantification experiments are substrate concentration, microbial culture, temperature and experimental set-up (batch or continuous experiment). Generally, the value of $\mathrm{K}_{\mathrm{s}}$ of anaerobic sludge increases (i.e. the affinity decreases) when temperature decreases, as shown by Lokshina et al. (2001) and Banik et al. (1998) for treating municipal landfill leachate and synthetic municipal wastewater. $\mathrm{K}_{\mathrm{s}}$ and mass transfer limitations may 
additionally impact methanogenesis and its dependency on temperature (Speece, 2008). A higher $\mathrm{K}_{\mathrm{s}}$ and poor mass transfer lead to a higher dependency on temperature.

\subsubsection{Effects of low temperature on anaerobic conversion}

\subsubsection{Effects of low temperature on anaerobic hydrolysis}

Anaerobic treatment of low temperature municipal wastewater $\left(\leq 15^{\circ} \mathrm{C}\right)$ is still a challenge, mainly due to the low hydrolysis rate of organic solids and the related long SRT, and therefore long HRTs (Lettinga et al., 2001). Municipal wastewater has a considerably high $\mathrm{COD}_{\mathrm{ss}}$ fraction which may account for $50-65 \%$ of the $\mathrm{COD}_{\mathrm{t}}$. Nonbiodegraded $\mathrm{COD}_{\mathrm{ss}}$ will accumulate in the sludge bed when the wastewater temperature is low and HRT not long enough. As a result, the SRT, hydrolytic and methanogenic capacity of the sludge will decrease.

The hydrolysis efficiency of $\mathrm{COD}_{\mathrm{ss}}$ was as low as $12 \%$ during batch digestion for 125 days of cow manure at $5^{\circ} \mathrm{C}$ (Zeeman, 1991a). When operating a UASB reactor for municipal wastewater treatment at an HRT of $3 \mathrm{~h}$ and $17^{\circ} \mathrm{C}$, the particulate organic matter was effectively removed by entrapment in the sludge bed, but the hydrolysis efficiency of the entrapped organics was only $0.7 \%$ (Zeeman et al., 1997). Uemura and Harada (2000) showed a drop in the hydrolysis efficiency from $58 \%$ at $25^{\circ} \mathrm{C}$ to $33 \%$ at $13^{\circ} \mathrm{C}$, when applying a UASB reactor for municipal wastewater treatment at an HRT of $4.7 \mathrm{~h}$. Also the anaerobic treatment of black water in a UASB-septic tank was shown to have a poor performance during the winter period (temperature lower than $14{ }^{\circ} \mathrm{C}$ ); $60 \%$ of the influent COD was accumulated as solids in the sludge bed while about $30 \%$ was discharged as soluble COD ( $\left.\mathrm{COD}_{\text {sol }}\right)$ with the effluent (Luostarinen et al., 2007).

\subsubsection{Effect of fluctuating temperature on anaerobic wastewater treatment}

Effects of temperature change on anaerobic processes were investigated in various studies. The difference in biogas production between winter $\left(14-25^{\circ} \mathrm{C}\right)$ and summer $\left(24-35^{\circ} \mathrm{C}\right)$ in Brazil was studied, when applying a pilot scale tubular continuous anaerobic digester for digestion of cattle manure at an HRT of $60 \mathrm{~d}$ (Resende et al., 2015). No difference in average methane yield was found as temperature gradually changed given the long HRT. Biogas production rate under daily down and upward temperature fluctuations was studied when applying anaerobic digestion of cow manure in a continuous stirred tank reactor (CSTR) at 50 and $60^{\circ} \mathrm{C}$ at an $\mathrm{HRT}$ of $20 \mathrm{~d}$ (ElMashad et al., 2004). Biogas production rate at $50^{\circ} \mathrm{C}$ was higher than at $60^{\circ} \mathrm{C}$ when a $10^{\circ} \mathrm{C}$ temperature reduction was applied for $10 \mathrm{~h}$ or a $10^{\circ} \mathrm{C}$ increase for $5 \mathrm{~h}$. Lau and Fang (1997) reported that suddenly applied changes in temperature, from 55 to $37^{\circ} \mathrm{C}$, resulted in poor COD removal, granule disintegration and biomass washout when applying a thermophilic granule reactor fed with sucrose and operated at $55^{\circ} \mathrm{C}$. Kettunen and Rintala (1997a) reported a 1 d lag-phase when using sludge, collected from a UASB reactor treating leachate at $23^{\circ} \mathrm{C}$, for an SMA test at $15^{\circ} \mathrm{C}$. Gao et al. (2011) found that a decrease in temperature with 5 and $10^{\circ} \mathrm{C}$, starting at $37^{\circ} \mathrm{C}$, could be tolerated for a submerged anaerobic membrane bioreactor (SAMBR) operated at an 
HRT of $20 \mathrm{~h}$; the same changes, starting at $45^{\circ} \mathrm{C}$, led to a significant disturbance of the performance.

\subsubsection{Different types of anaerobic reactors}

The main anaerobic reactors used for wastewater treatment can be classified as low rate or high rate systems as shown in Fig.1.3. High rate systems are characterized by retention of sludge (SRT $>$ HRT), while most low rate systems have no sludge retention $(\mathrm{SRT}=\mathrm{HRT})$

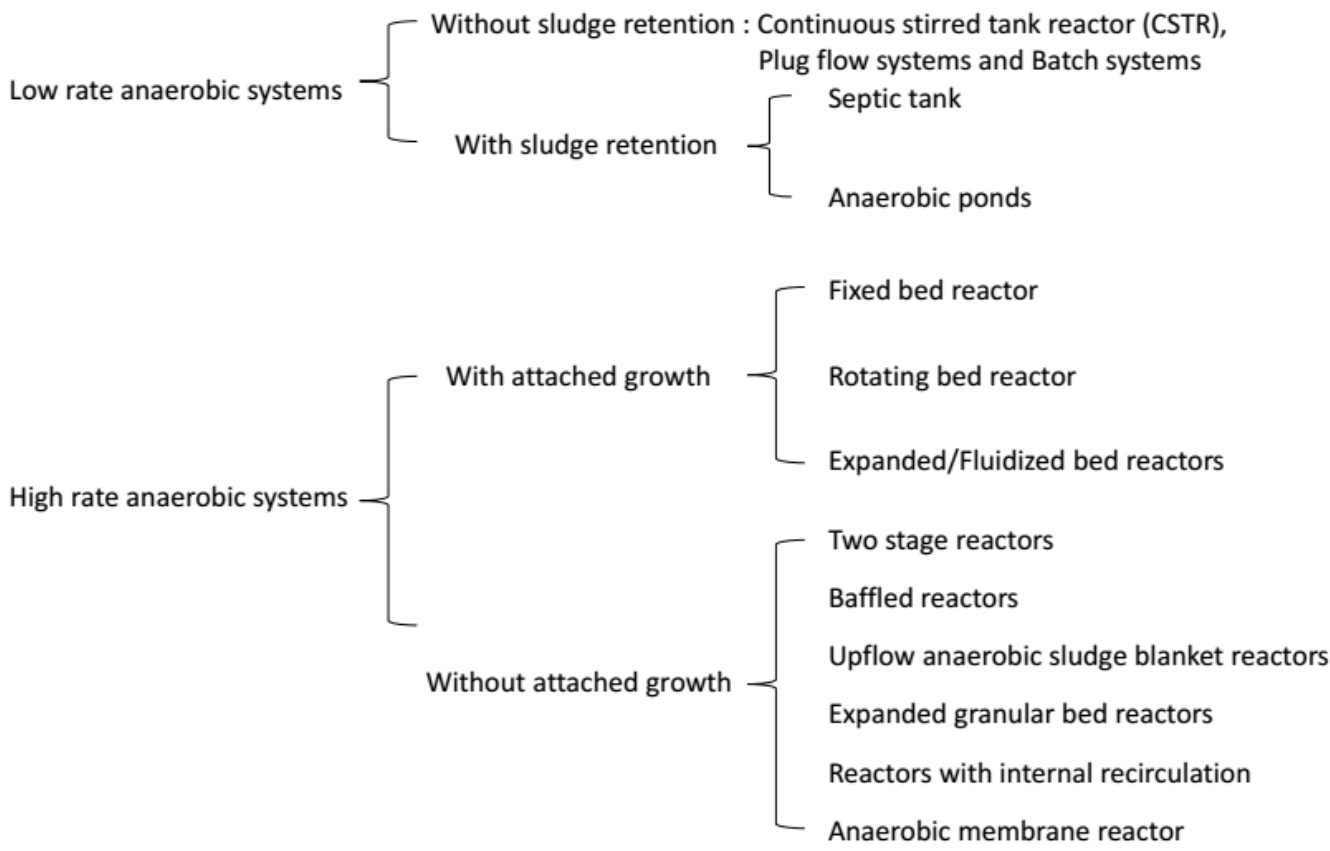

Fig.1.3 Main types of anaerobic reactors used for wastewater treatment (Based on (Sperling \& Chernicharo, 2005))

\subsubsection{Low rate anaerobic systems}

\section{$\underline{\text { Without sludge retention }}$}

Anaerobic systems without sludge retention are operated at relatively low volumetric organic loads, long hydraulic retention times (HRTs) and in general fed with highly concentrated waste streams. CSTRs are the most frequently applied systems, and for example used for the stabilization of primary and secondary sludge originating from wastewater treatment plants, for industrial effluents with a high concentration of suspended solids ( $\mathrm{Li}$ et al., 2011) and animal manure. The applied operational temperature ranges mostly from 25 to $35^{\circ} \mathrm{C}$, at HRTs $\geq 20$ days, though thermophilic treatment is also more and more applied.

\section{$\underline{\text { With sludge retention }}$}

The septic tank is a unit that has functions of sedimentation and removal of floatable materials. It acts as a low-rate treatment system without mixing and heating possibilities 
(Lowe \& Siegrist, 2008). Solids are retained in the system as a result of sedimentation. The SRT is therefore much longer than the HRT.

Anaerobic ponds are an alternative for municipal wastewater treatment in warm-climate regions and also often used in the past for wastewater treatment with a high concentration of organic matter (Mara, 1987). Anaerobic ponds can be classified as low volumetric organic loaded reactors due to their large footprint and long HRT. Solids are settled and retained in the system.

\subsubsection{High rate systems}

Anaerobic filters are characterized by the presence of a stationary packing material to which biomass can attach and be maintained within the interstices (Young \& McCarty, 1969). The average SRT is above $20 \mathrm{~d}$. A good treatment performance can be achieved because of the longer SRT. The main disadvantage of anaerobic filters is that the accumulation of biomass can lead to blockage or the formation of hydraulic short circuits. Rotating bed anaerobic reactor is also called anaerobic biodisc, in which biomass was attached to submerged discs (Noyola et al., 1988). The SRT is high and blocking should not occur as the rotation of the discs provides shearing forces and remove the excess biomass present between the discs. Expanded bed anaerobic reactors consist of a cylindrical structure, packed with inert support materials like sand, gravel, coal etc. which accounts for about $10 \%$ of the total reactor volume (Switzenbaum \& Jewell, 1980). In expanded bed anaerobic reactors, the expansion of the bed is maintained between 10-20\%; in fluidized bed anaerobic reactors, the expansion varies between $30-100 \%$. The expanded anaerobic reactors have proven to be efficient in treating low strength, pre-treated municipal wastewater at temperatures $\geq 20^{\circ} \mathrm{C}$ at a short HRT (minimum from 0.5 to $1 \mathrm{~h}$ ); COD removal efficiencies of $60-70 \%$ can be achieved. The fluidized bed anaerobic reactors can achieve a high OLR of $20-30 \mathrm{~kg}$ $\mathrm{COD} /\left(\mathrm{m}^{3} \mathrm{~d}\right)$ using soluble wastes and COD removal efficiencies of 70-90\% (GarciaCalderon et al., 1998; Şen \& Demirer, 2003). However, van Lier et al. (2015) reported that the fluidized bed anaerobic reactors turned out not to be successful in practice as the biofilm loosened from the support material.

Anaerobic baffled reactors (ABRs) are equipped with vertical baffles that force the liquid to make a sequential downflow and upflow, to enable good contact between the biomass and wastewater (Barber \& Stuckey, 1999). OLR of ABRs can reach $36 \mathrm{~kg}$ $\mathrm{COD} /\left(\mathrm{m}^{3} \mathrm{~d}\right)$. It can have a smaller depth and be built without a gas separator, which saves construction costs. However, loss of biomass may occur in the case of influent flow variation as the ABRs do not have a gas separator for sludge retention.

An upflow anaerobic sludge bed (UASB) reactor has a gas-solids-liquid separator at the top of the reactor, which separates SRT and HRT (Lettinga, 1995). Biogas produced, provides good mixing of biomass and substrate. The sludge settles after gas separation, which makes the UASB reactor also to work like a clarification tank. The UASB reactor can retain a high concentration of biomass, which is in the form of granules or wellsettling flocculent sludge (De Sousa \& Foresti, 1996; Torres \& Foresti, 2001). The upflow velocity is in such systems in the range of $0.5-2 \mathrm{~m} / \mathrm{h}$. A UASB reactor is suitable 
for treating concentrated and dilute wastewater, with or without suspended solids. Organic loading rates range between 2 and $25 \mathrm{~kg} \mathrm{COD} / \mathrm{m}^{3} / \mathrm{d}$, depending on type of wastewater and applied temperature (Lier et al., 2008).

An EGSB reactor is a modification of the UASB reactor, which is significantly taller and has a high upflow velocity of 6-15 m/h (Lettinga et al., 1997). Biomass and organic matter can be well mixed due to the high upflow velocity. Slowly settling particulates, present in the influent, do not accumulate in the reactor and are likely washed out with the effluent. Therewith, the EGSB reactor is suitable for low temperature and low strength wastewater, but not suitable for wastewater with a high fraction of low density organic particulates. Internal circulation reactor has a very high upflow velocity, 20-30 $\mathrm{m} / \mathrm{h}$ (Deng et al., 2006; Pereboom, 1994; Pereboom \& Vereijken, 1994). It has 2 three phase separators. One is set in the middle of the reactor, the second set similar to a UASB reactor. Van Lier et al (2015) report the successful full-scale operation of modern EGSB installations, such as the Biobed EGSB and Biopaq IC reactors, applying various wastewaters at loading rates between $25-35 \mathrm{~kg} \mathrm{COD} /\left(\mathrm{m}^{3} \mathrm{~d}\right)$.

Anaerobic membrane reactors (AnMBRs) were intensively studied due to their high effluent quality. For AnMBRs of municipal wastewater treatment, the effluent mainly contains macronutrients like nitrogen and phosphorus, while COD, SS and pathogens can be well removed (Liao et al., 2006). Therewith, the effluent can be used in agriculture. Sludge retention provided by the membrane may increase the SMA and biodegradation (Ho \& Sung, 2010; Martinez-Sosa et al., 2011). Anaerobic reactors like bench-scale CSTR, UASB, EGSB, UASB-digester coupled with different types of membrane achieved COD removal between $87-92 \%$ for municipal wastewater treatment (Chu et al., 2005; Gouveia et al., 2015; Ozgun et al., 2015; Smith et al., 2013).

Most of the studies about AnMBRs are executed in bench scale experiments, and information on cost and energy analysis is limited. The main drawbacks of AnMBRs are the low membrane flux and the related large surface area of the membrane, membrane fouling, high capital and operational costs, which still hinder AnMBRs application (Chernicharo et al., 2015).

\subsection{Anaerobic municipal wastewater treatment in tropical}

\section{areas}

The UASB reactor was invented in the 1980s (Lettinga et al. 1980). The first research of a full scale UASB reactor, treating municipal wastewater, was conducted in Colombia (Schellinkhout \& Collazos, 1992). Several tropical countries in Latin America and India started to apply anaerobic municipal wastewater treatment technology afterwards. In these countries, climate conditions are favorable for the application of mesophilic anaerobic reactors. In India, full scale UASB reactors have been implemented since 1990 and the UASB reactor is considered as a standard technology for municipal wastewater treatment (Uemura and Harada 2010). As shown 


\begin{tabular}{l}
\hline stabilization pond $\square$ activated sludge UASB \\
aerated pond $\square$ wetland $\square$ trickling filter \\
\hline imhoff tank $\quad$ anaerobic filter enchanced primary treatment \\
aerobic submerged filter $\square$ rotating biological contactor
\end{tabular}

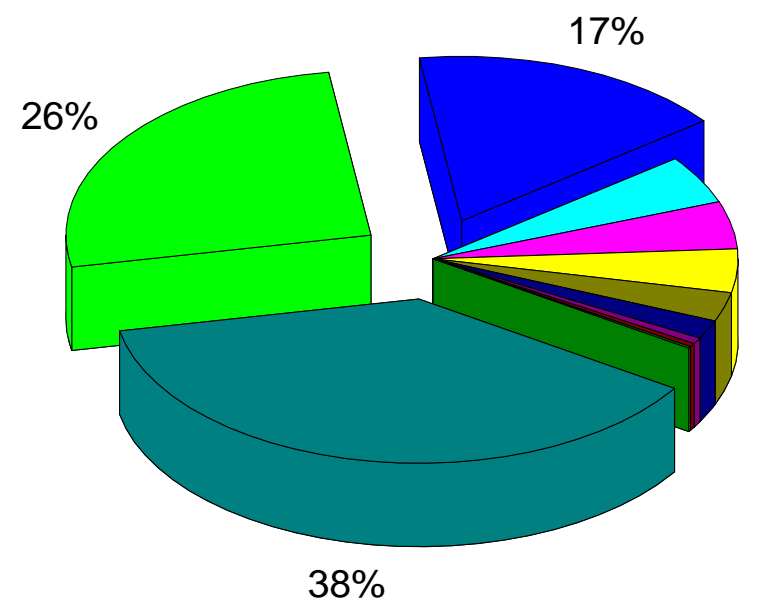

Fig.1.4 Major technologies for municipal wastewater treatment in Latin American region (modified from Noyola et al. (2012))

in Fig.1.4, UASB reactors are the third most applied municipal wastewater treatment technology in Latin American region.

Anaerobic wastewater treatment followed by aerobic post treatment was considered as an alternative to traditional wastewater treatment using an activated sludge process. The costs of a treatment plant with a UASB reactor followed by aerobic biological treatment are usually $20-50 \%$ lower for capital expenditures (CAPEX) and 50\% for operational expenditures (OPEX) compared with a conventional activated sludge plant (Chernicharo, 2006; Polito Braga et al., 2005). A UASB reactor followed by a stonefilled trickling filter saves $40 \%$ CAPEX and 90\% OPEX compared with a conventional activated sludge system (Aiyuk et al., 2006). The advantages and disadvantages of anaerobic wastewater treatment are shown in Table 1.1.

The UASB reactor is one of the most frequently applied anaerobic wastewater treatment technologies, being applied in tropical areas (Fang \& Chung, 1999; Hulshoff Pol \& Lettinga, 1986; Lettinga et al., 1993; Verstraete \& Vandevivere, 1999). The performance of full scale UASB reactors applied in Brazil, India, Jordan, Middle East, Colombia and Mexico is shown in Table 1.2. COD, biological oxygen demand (BOD) and total suspended solids (TSS) removal efficiencies varies from 41 to $80 \%$, from 40 to $84 \%$ and from 34 to $85 \%$ respectively. 


\subsection{Anaerobic treatment of low temperature wastewater}

Temperature is one of the limitations for applying anaerobic municipal wastewater treatment in e.g. the Netherlands. But compared to tropical countries, also reaching discharge limits is a challenge, as they are generally stricter than in tropical countries (in e.g. Brazil there is not (yet) a discharge limit on total nitrogen, but only on ammonium). Removing all BOD in an anaerobic reactor, makes the conventional route for nitrogen removal not possible anymore (unless an external C-source is added); and also phosphate removal is often done via biological phosphorus removal, for which organic carbon is required as well. Ideally nitrogen and phosphorus are recovered after anaerobic treatment, but latter is limited by the low concentrations. Nitrogen can also be removed by autotrophic processes such as anaerobic ammonia oxidation (ANAMMOX) or denitrification anaerobic methane oxidation (DAMO) process (Hendrickx et al., 2012; Kampman et al., 2012). Phosphorus could be removed by iron precipitation (Parsons \& Smith, 2008). The present study focuses on anaerobic treatment to recover chemical energy from organic matter in municipal wastewater.

\subsubsection{Single anaerobic reactors}

Temperature of municipal wastewater in large parts of the world is lower than required for anaerobic treatment, at least when a short HRT is applied. Low temperature anaerobic wastewater treatment has recently been intensively studied, and different types of anaerobic reactors have been investigated, as shown in Table 1.3. Generally, these single anaerobic reactors achieved COD removal efficiencies of $37 \%$ to $90 \%$ at a temperature range of $10-25^{\circ} \mathrm{C}$. This is achieved by applying anaerobic reactors such as UASB reactors, EGSB reactors, ABRs, anaerobic migrating blanket reactors (AMBRs) and anaerobic membrane bio-reactors (AnMBRs) as shown in Table 1.3. At low temperature, anaerobic treatment with granular sludge and easily biodegradable substrate, methanogenesis is not a limiting factor (Lettinga et al., 1999; Rebac et al., 1999a; Van Lier et al., 1997).

An UASB reactor was investigated for low-strength municipal wastewater treatment at 6 to $32^{\circ} \mathrm{C}$, and an HRT range from 25 to $4 \mathrm{~h}$ (Singh \& Viraraghavan, 2000). The startup of the UASB reactor was achieved in $60 \mathrm{~d}$ at $20^{\circ} \mathrm{C}$. COD and BOD removal efficiencies were from 38 to $90 \%$ and 47 to $91 \%$ respectively. A lab-scale UASB reactor with a height of $1.65 \mathrm{~m}$ was studied for treating municipal wastewater at low temperatures in the city of Peru and COD removal efficiencies were achieved between 37 and 62\% (Yaya-Beas et al., 2016).

An EGSB reactor was studied under psychrophilic conditions $\left(10-12^{\circ} \mathrm{C}\right)$, which was seeded with mesophilic granular sludge and fed with VFA mixture (Rebac et al., 1995; Rebac et al., 1999c; Van der Last \& Lettinga, 1992). COD removal efficiencies can exceed $90 \%$ with influent COD concentrations from 500 to $800 \mathrm{mg} \mathrm{COD} / \mathrm{L}$ at an organic loading rate of $12 \mathrm{~g} \mathrm{COD/}(\mathrm{ld})$ at HRT of 2.5 and $1.6 \mathrm{~h}$ respectively. 
Table 1.1 Comparison of anaerobic wastewater treatment of municipal wastewater to activated sludge system

$\begin{array}{ll}\text { Advantages } & \text { Disadvantages }\end{array}$

Low operational costs as no energy required for aeration;

Primary sludge sedimentation tank, activated sludge system, secondary clarification and the sludge digester can be replaced by a UASB reactor;

Energy can be recovered in terms of methane;

Small footprint;

The sludge production is low, well stabilized and easily dewatered;

The valuable nutrients ( $\mathrm{N}$ and $\mathrm{P}$ ) are conserved which can be reused for agriculture.

\section{UASB requires post treatment step;}

Anaerobic COD removal efficiency is lower than activated sludge process;

Dissolved $\mathrm{CH}_{4}$ is lost in the effluent (especially at low temperature)

Potentially higher $\mathrm{CH}_{4}$ (Greenhouse Gas, GHG) emission due to dissolved $\mathrm{CH}_{4}$ in effluent anaerobic step;

Full scale application was not yet commercially developed at moderate to low temperatures. 
Table 1.2 Performance of Full scale UASB reactors applied in tropical countries

\begin{tabular}{|c|c|c|c|c|}
\hline \multirow{3}{*}{ Country } & \multicolumn{3}{|c|}{ Removal efficiencies (\%) } & \multirow{3}{*}{ Literatures } \\
\hline & & & & \\
\hline & COD & BOD & TSS & \\
\hline Brazil & $58-79$ & $74-84$ & $49-71$ & $\begin{array}{l}\text { Rosa et al. (2012), Oliveira and } \\
\text { von Sperling (2011) and Da Silva } \\
\text { et al. (2013) }\end{array}$ \\
\hline India & $41-45$ & $40-60$ & $34-47$ & $\begin{array}{l}\text { Mungray and Patel (2011) and } \\
\text { Walia et al. (2011) }\end{array}$ \\
\hline Jordan & 58 & - & 62 & Halalsheh et al. (2005) \\
\hline Middle east & 71 & 70 & 85 & Nada et al. (2011) \\
\hline Colombia & 66 & 78 & 69 & Peña et al. (2000) \\
\hline Mexico & $70-80$ & - & - & Monroy et al. (2000) \\
\hline
\end{tabular}


A pilot scale four-chamber ABR achieved a COD removal efficiency of $43 \%$ when treating raw municipal wastewater at $12-23^{\circ} \mathrm{C}$ and an HRT of $12 \mathrm{~h}$ for two years (Hahn \& Figueroa, 2015). A three-chamber ABR was studied for the treatment of low-strength synthetic wastewater at an influent COD concentration of 300 to $400 \mathrm{mg} / \mathrm{L}$ (Manariotis \& Grigoropoulos, 2002). COD removal efficiency was 87 and $91 \%$ at $26^{\circ} \mathrm{C}$ and an HRT of 24 and $12 \mathrm{~h}$, respectively. At $16{ }^{\circ} \mathrm{C}$, COD removal efficiency was similar to that before decreasing the temperature. An eight-chamber ABR was studied for treating a dilute wastewater with a COD concentration of $500 \mathrm{mg} / \mathrm{L}$ and a COD removal of $>70 \%$ was achieved at $10^{\circ} \mathrm{C}$ and an HRT of $10 \mathrm{~h}$ (Langenhoff \& Stuckey, 2000).

A compartmentalized AMBR was studied for the treatment of low-strength soluble wastewater at low-temperature (Angenent et al., 2002; Angenent et al., 2001). AMBR was fed nonfat dry milk substrate as a synthetic wastewater at 15 and $20^{\circ} \mathrm{C}$ in an operating period of 186 days. The influent $\mathrm{COD}$ and $\mathrm{BOD}_{5}$ concentration were constant at 600 and $285 \mathrm{mg} / \mathrm{L}$, respectively. $\mathrm{COD}_{\text {sol }}$ removal efficiency was $73 \%$ at $15^{\circ} \mathrm{C}$ at an HRT of $4 \mathrm{~h}$, and $\mathrm{COD}_{\mathrm{t}}$ removal efficiency was $59 \%$. Biomass was retained effectively and SRT was always greater than $50 \mathrm{~d}$.

The feasibility of an AnMBR for municipal wastewater treatment was investigated and COD removal efficiency of $>89 \%$ was achieved at $15^{\circ} \mathrm{C}$ and an HRT of $6 \mathrm{~h}$ (Ozgun et al., 2015).

A pilot scale AnMBR that consisted of a UASB reactor with an external ultrafiltration membrane treating municipal wastewater at $18^{\circ} \mathrm{C}$, was evaluated over three years of stable operation (Gouveia et al., 2015). The AnMBR achieved a COD removal efficiency of $87 \%$ at an HRT of $7 \mathrm{~h}$, and the effluent $\mathrm{COD}$ and $\mathrm{BOD}_{5}$ concentrations were $100-120 \mathrm{mg} / \mathrm{L}$ and $35-50 \mathrm{mg} \mathrm{O}_{2} / \mathrm{L}$, respectively. Specific methane yield varied from 0.18 to $0.23 \mathrm{Nm}^{3} \mathrm{CH}_{4} / \mathrm{kg} \mathrm{COD}$ removed.

A bench-scale AnMBR equipped with submerged flat-sheet microfiltration membranes was studied using synthetic and actual municipal wastewater (DWW) at $15^{\circ} \mathrm{C}$ (Smith et al., 2013). The average COD removal efficiency was $92 \%$ and provided a good effluent quality of $36 \mathrm{mg} \mathrm{COD} / \mathrm{L}$ during the operation with simulated wastewater. Dissolved methane in the effluent accounted for a substantial fraction (40-50\%) of the total methane production and the effluent was more than saturated according to Henry's law; part of the methane is present as gas microbubbles in the liquid phase. COD removal efficiency averaged 69\% during actual DWW operation. The average effluent $\mathrm{COD}$ and $\mathrm{BOD}_{5}$ were $76 \mathrm{mg} / \mathrm{L}$ and $24 \mathrm{mg} / \mathrm{L}$, respectively. A microbial analysis on bacterial and archaeal microbial communities in the AnMBR was performed and the results show that a mesophilic inoculum is suited for psychrophilic AnMBRs treating low strength wastewater.

\subsubsection{Combined anaerobic reactors}

Combinations of AF-AH, an EGSB with an AF, HUSB - UASB and UASB-digester systems were studied in different researches for low temperature anaerobic wastewater 
treatment as shown in Table 1.3. Each will be discussed in the following paragraph.

\subsubsection{AF-AH reactor}

A two-step anaerobic filter $(\mathrm{AF})+$ anaerobic hybrid $(\mathrm{AH})$ reactor was studied for treatment of municipal wastewater at $13^{\circ} \mathrm{C}$. The $\mathrm{AH}$ reactor consisted of a granular sludge bed with vertical sheets of reticulated polyurethane foam (RPF) with knobs. The $\mathrm{RPF}$ was used for entrapment of solids. This $\mathrm{AF}+\mathrm{AH}$ system achieved a $\mathrm{COD}_{\mathrm{ss}}$ removal efficiency of $81 \%$ and $\mathrm{COD}_{\mathrm{t}}$ removal efficiency of $71 \%$ at HRTs of $4 \mathrm{~h}(\mathrm{AF})$ and $8(\mathrm{AH})$ h (Elmitwalli et al., 2002a; Elmitwalli et al., 2002b). However, the excess sludge that is produced by entrapment of influent $\mathrm{COD}_{\mathrm{ss}}$ in these systems still needs further treatment. The AF-AH system can achieve a longer SRT in the AH reactor when treating low temperature municipal wastewater containing considerable $\mathrm{COD}_{\mathrm{ss}}$. However, excess sludge still needs stabilization.

\subsubsection{EGSB - AF}

An EGSB-AF reactor seeded with mesophilic sludge was studied for the treatment of a medium-strength $5 \mathrm{~g} \mathrm{COD} / \mathrm{L}$, synthetic, volatile fatty acid-based wastewater for a longterm operation of 625 days at $15^{\circ} \mathrm{C}$ (Connaughton et al., 2006). COD removal efficiency of $>80 \%$ was achieved, and the results were highlighted by a short start-up period of $21 \mathrm{~d}$, a short HRT of $4.9 \mathrm{~h}$, high OLR of $24.6 \mathrm{~kg} \mathrm{COD} /\left(\mathrm{m}^{3} \mathrm{~d}\right)$. The contribution of hydrogenotrophic methanogenesis to methane production was increased compared to acetoclastic methanogenesis. The biomass was still mesophilic but can be characterized as strongly active psychro-tolerent. The EGSB-AF system is suitable for low temperature wastewater mainly containing $\mathrm{COD}_{\text {sol }}$, but needs pre-treatment for wastewater having a large fraction of $\mathrm{COD}_{\text {ss. }}$.

\subsubsection{HUSB - UASB}

A two - stage anaerobic treatment pilot plant HUSB-UASB was studied for treatment of raw municipal wastewater at temperatures from 21 to $14^{\circ} \mathrm{C}$ (Álvarez et al., 2008). The HRT of the HUSB and UASB were from 5.7 to $2.8 \mathrm{~h}$ and 13.9 to $6.5 \mathrm{~h}$ respectively. $\mathrm{COD}_{\mathrm{t}}$ and BOD removal efficiencies were $49-65 \%$ and 50 to $77 \%$, respectively. The hydrolysis efficiency of influent suspended solids was $59.7 \%$. Like the AF-AH system, the HUSB-UASB system is able to achieve good $\mathrm{COD}_{\mathrm{ss}}$ removal at low temperatures, but the sludge produced in the HUSB is not stabilised.

\subsubsection{UASB-digester}

Mahmoud et al. (2004) investigated a UASB-digester system for low temperature municipal wastewater treatment. This system treats wastewater in a UASB reactor at a short HRT. The UASB sludge is recirculated over a heated digester where the wastewater $\mathrm{COD}_{\mathrm{ss}}$, captured in the UASB reactor, is converted to methane. The stabilized digester sludge is returned to the UASB reactor where it continues to capture wastewater organic solids and at the same time supplies methanogenic biomass to the UASB reactor for conversion of the $\mathrm{COD}_{\text {sol }}$ in the wastewater. The UASB-digester 
Table 1.3 Anaerobic treatment of low temperature wastewater (influent COD concentration, temperature, HRT and COD removal efficiencies)

\begin{tabular}{ccccccc}
\hline Types & Substrate & $\begin{array}{c}\text { Influent } \\
\text { COD } \\
\text { concentration } \\
(\mathrm{mg} / \mathrm{L})\end{array}$ & $\begin{array}{c}\text { Temperature } \\
\left({ }^{\circ} \mathrm{C}\right)\end{array}$ & HRT (h) & $\begin{array}{c}\text { COD } \\
\text { removal } \\
\text { efficiency } \\
(\%)\end{array}$ & Literatures \\
\hline UASB & Municipal wastewater & 621 & 12.5 & $4-14$ & $37-62$ & Yaya-Beas et al. (2016) \\
& Municipal wastewater & - & 11 & 6 & $70-90$ & $\begin{array}{c}\text { Singh and Viraraghavan (2000) and } \\
\text { Singh and Viraraghavan (2003) }\end{array}$ \\
& Wastewater & 312 & $13-25$ & 4.7 & 70 & Uemura and Harada (2000) \\
EGSB & Mixture of VFA & $500-800$ & $10-12$ & $1.6-2.5$ & $>90$ & Rebac et al. (1995) and Rebac et al. \\
(1999c)
\end{tabular}




\begin{tabular}{|c|c|c|c|c|c|c|}
\hline \multirow[t]{4}{*}{ AnMBR } & Milk powder & 530 & 15 & 6 & $>89$ & Ozgun et al. (2015) \\
\hline & Municipal wastewater & $580-730$ & 18 & 7 & 87 & Gouveia et al. (2015) \\
\hline & Municipal wastewater & 259 & 15 & 16 & 69 & Smith et al. (2013) \\
\hline & $\begin{array}{l}\text { Non-fat dry milk and } \\
\text { soluble starch }\end{array}$ & 500 & 25 & 6 & 94 & Ho and Sung (2009) \\
\hline AF-AH & Municipal wastewater & 518 & 13 & $\begin{array}{c}4(\mathrm{AF})-8 \\
(\mathrm{AH})\end{array}$ & 71 & $\begin{array}{l}\text { Elmitwalli et al. (2002a) and } \\
\text { Elmitwalli et al. (2002b) }\end{array}$ \\
\hline EGSB-AF & Mixture of VFA & 5000 & 15 & 4.8 & $>80$ & Connaughton et al. (2006) \\
\hline $\begin{array}{l}\text { HUSB- } \\
\text { UASB }\end{array}$ & Municipal wastewater & 118 & 14 & $\begin{array}{c}5.7 \\
\text { (HUSB)- } \\
11.6(\mathrm{UASB})\end{array}$ & 53 & Álvarez et al. (2008) \\
\hline \multirow[t]{2}{*}{$\begin{array}{l}\text { UASB- } \\
\text { digester }\end{array}$} & Municipal wastewater & 460 & 15 & 6 & 66 & Mahmoud et al. (2004) \\
\hline & Municipal wastewater & $330-360$ & 15 & 6 & 52 & Álvarez et al. (2004) \\
\hline
\end{tabular}


system includes a sludge digester which enables a low excess sludge production, but the recirculation of the UASB sludge to the digester consumes energy. So far, only limited studies show the feasibility of the UASB-digester system for municipal wastewater treatment at $15^{\circ} \mathrm{C}$. However, the temperature of municipal wastewater in moderate climate zones can be as low as $10^{\circ} \mathrm{C}$ and therefore, the feasibility of the UASB-digester also needs to be assessed at temperatures below $15^{\circ} \mathrm{C}$.

\subsection{Scope of this thesis}

To achieve that anaerobic treatment of low strength municipal waste water can be applied at low temperatures and not only at higher temperature regimes, a pilot-scale UASB-digester is studied in this thesis. The temperature was subsequently decreased, in steps, to $10^{\circ} \mathrm{C}$ and removal efficiency for $\mathrm{COD}_{\mathrm{t}}$ and of its fractions (suspended, soluble and colloidal), methane production of the UASB reactor and the digester and the COD balance were determined. This study addresses the mechanisms behind the successful operation of such a UASB-digester treating municipal wastewater under moderate climate conditions, using real wastewater from an influent of a WWTP in Bennekom the Netherlands, with moderate temperature and COD composition. The research route is shown in Fig. 1.5. The recirculation rate and sludge recirculation point are important control parameters influencing the performance of the system and become part of this research (Chapter 2). The research is carried out with real municipal wastewater with fluctuating COD concentrations and COD fractions. The effect of these fluctuations on reactor performance is studied and mitigation methods for improving performance of the UASB-digester are developed (Chapters 3 and 4). Fundamental aspects are studied in small-scale batch experiments. First order hydrolysis rates and kinetics of methanogenesis are studied after a sudden change in temperature, as taking place in the UASB-digester when transferring sludge between the UASB and the digester and back (Chapter 5 and 6). Results of this study play an important role in understanding the UASB-digester system treating low temperature municipal wastewater and finding the optimal operational conditions. 


\section{Scheme to achieve energy sufficient wastewater treatment}

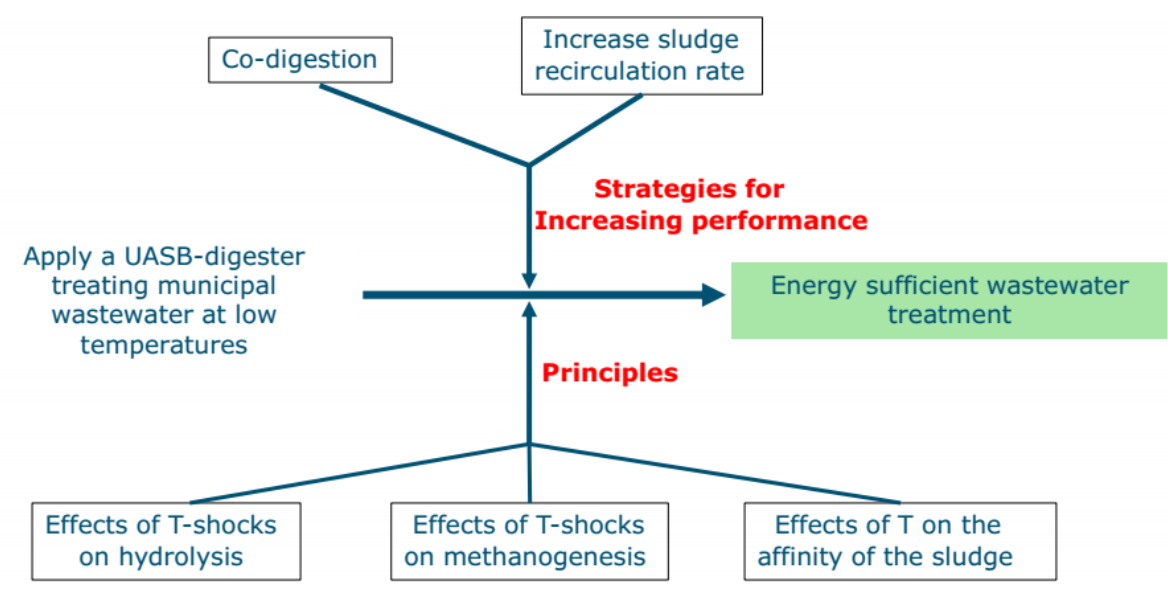

Fig.1.5 The research scheme of this thesis 


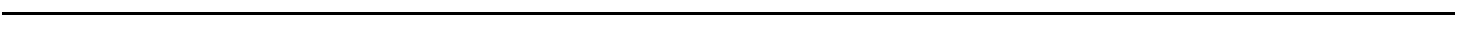




\section{Effects of sludge recirculation rate and Sludge transfer point on a UASB-digester system to treat domestic sewage at $15^{\circ} \mathrm{C}$}

Lei Zhang, Tim L.G. Hendrickx, Christel Kampman, Grietje Zeeman, Hardy Temmink, Weiguang Li, Cees J.N. Buisman, Huub Rijnaarts

Part of this chapter has been accepted for publication in Water Science and Technology, 2012, doi: $10.2166 /$ wst.2012.487

Part has been accepted for 13th World Congress on Anaerobic Digestion: Recovering (bio) Resources for the World. Santiago de Compostela, Spain, 2013, June 25-28. 


\begin{abstract}
The anaerobic treatment of low strength domestic sewage at low temperature is an attractive and important topic at present. A UASB-digester system is one of the successful anaerobic systems to challenge low temperature and concentrations. The effect of sludge recirculation rate and height of UABS sludge transfer (HUST) on UASB-digester treating domestic sewage at $15{ }^{\circ} \mathrm{C}$ was studied in this research. A sludge recirculation rate of $1 \%, 2.6 \%$ and $12.5 \%$ of the influent flow rate was investigated respectively. The results showed that the total COD removal efficiency rose with increasing sludge recirculation rate. A sludge recirculation rate of $1 \%$ of the influent flow rate leads to organic solids accumulation in the UASB. After the sludge recirculation rate increased from $1 \%$ to $2.6 \%$, the stability of the UASB sludge was substantially improved from 0.37 to $0.15 \mathrm{~g} \mathrm{CH}_{4}-\mathrm{COD} / \mathrm{g} \mathrm{COD}$, and the biogas production in the digester went up from 2.9 to $7.4 \mathrm{~L} / \mathrm{d}$. The stability of the UASB sludge and biogas production in the digester were not significantly further improved by increasing sludge recirculation rate to $12.5 \%$ of the influent flow rate, but the biogas production in the UASB increased from $0.37 \mathrm{~L} / \mathrm{d}$ to $1.2 \mathrm{~L} / \mathrm{d}$. It is recommended to apply a sludge recirculation rate of $2-3 \%$ of influent flow rate in a UASB-digester system. Increased HUST resulted in a high VSS concentration of the UASB-digester system.
\end{abstract}




\subsection{Introduction}

Given the potential advantages of anaerobic compared to aerobic sewage treatment (e.g. less energy consumption, energy production and a lower sludge production), its application at moderate and low temperatures $\left(\leq 20{ }^{\circ} \mathrm{C}\right)$ would be very attractive (Lettinga et al., 2001). High-rate anaerobic reactors, such as Expanded Granular Sludge Bed (EGSB) and Anaerobic Baffled Reactor (ABR), have been reported to successfully treat synthetic wastewater at low temperature $\left(10{ }^{\circ} \mathrm{C}-20{ }^{\circ} \mathrm{C}\right)$ containing mainly soluble chemical oxygen demand (COD) (Langenhoff \& Stuckey, 2000; McKeown et al., 2009a). However, at low temperatures $\left(6-15{ }^{\circ} \mathrm{C}\right)$ the growth of methanogens is very slow and the hydrolysis of the biodegradable solids in sewage may be the rate limiting step of the process. (LeitÃ£o et al., 2006). As a consequence, suspended organic matter accumulates in the anaerobic reactor when the sludge retention time (SRT) is not sufficiently long (Luostarinen et al., 2007). The accumulated solids in the reactor replace the anaerobic biomass, and the biomass is also lost in the effluent by attachment to washed out solids. As a result, stability, specific methanogenic activity (SMA) and SRT of the sludge in a single Upflow Anaerobic Sludge Bed (UASB) reactor all decrease when the SRT becomes too short due to the organic solids accumulation. As a result, this sludge still requires stabilisation before appropriate reuse or final disposal (Seghezzo et al., 2006), and liquid effluent needs further treatment. The application of long SRT needs long HRT and therefore large reactor volume, which is economically not feasible. The combination of a UASB and a digester (UASB-digester) has been shown to be successful to treat domestic sewage with high concentrations of suspended organic solids at low temperature (Álvarez et al., 2004; Mahmoud et al., 2004 ; Mahmoud et al., 2008).

In this study, municipal sewage was treated in a UASB at $15^{\circ} \mathrm{C}$. As shown in Fig. 2.1, sludge recirculation connects a UASB and digester. The un-stabilized suspended sewage COD that is captured by the UASB sludge bed is transferred to the digester, which is operated at $35{ }^{\circ} \mathrm{C}$. At the same time, stabilized sludge from the digester is transferred to the UASB, herewith providing additional methanogenic biomass to convert soluble COD. In previous studies, the sludge recirculation rate was determined by control of the sludge bed height (Álvarez et al., 2004; Mahmoud et al., 2004). However, the data about sludge recirculation on the overall process is very limited, and the optimum for the treatment of domestic sewage at low temperature is still not clear. Yet, the amount of sludge that needs to be circulated is crucial to the viability of the UASB-digester, since it determines the required energy input to heat the transferred sludge from $15{ }^{\circ} \mathrm{C}$ to $35^{\circ} \mathrm{C}$.

The height of the UASB sludge transfer (HUST) from which sludge is transferred to the digester is important for the operation of a UASB-digester system and particularly for the dissolved COD removal in the UASB reactor. Previous studies on the UASBdigester system did not elaborate on the effect of HUST. Mahmoud et al (2004) applied sludge transfer from the top of the UASB sludge bed, but recommended doing this from 


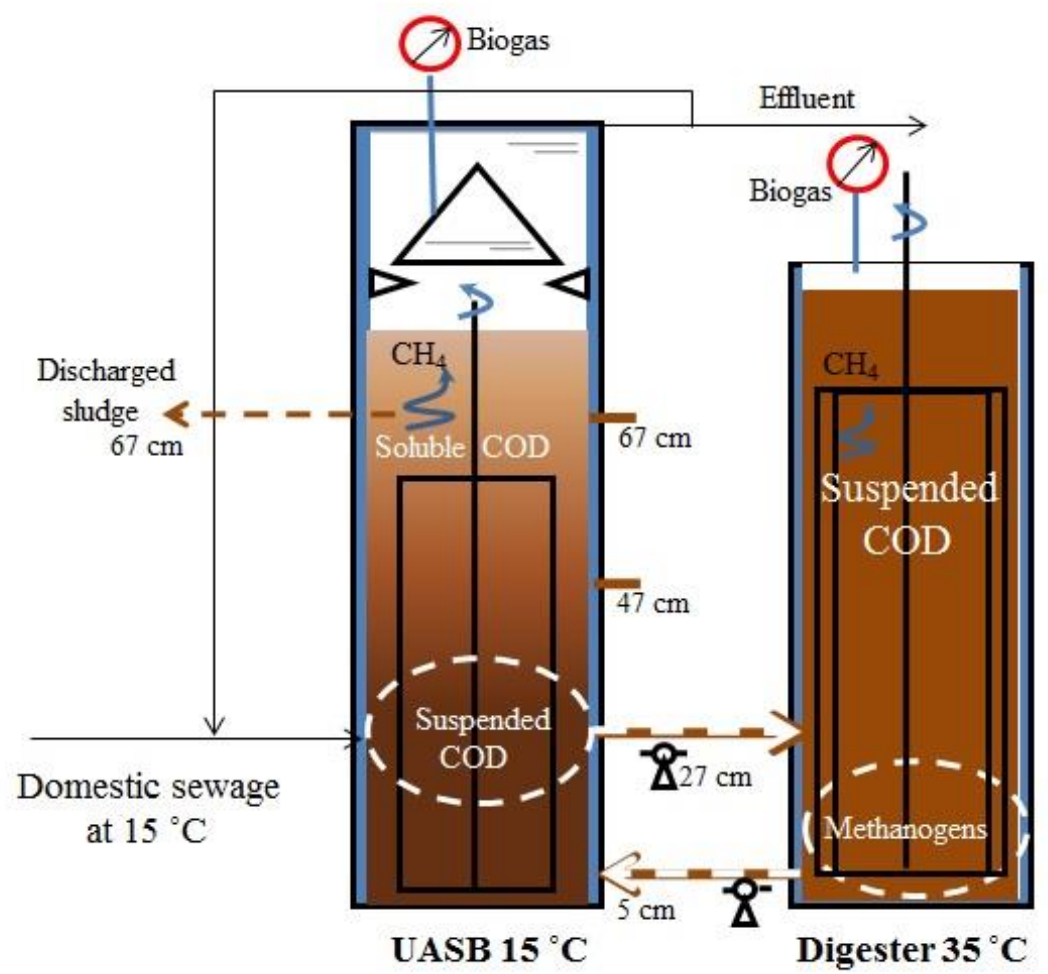

Fig. 2.1 The pilot-scale UASB-digester system in this research.

a lower point since the sludge concentration was higher there. Alvarez et al. (2004) transferred the sludge from 2 different heights, because of available sludge bed height. However, the specific effects of changing the HUST were not shown.

In this work, the effect of the sludge recirculation rate and HUST in UASB-digester system on COD removal efficiency, bio-gas production, the stability and specific methanogenic activity (with acetate) of the UASB-digester sludge, was investigated.

\subsection{Method and materials}

\subsubsection{Inoculum and sewage}

The inoculum sludge used in the UASB-digester system was taken from a primary sludge digester operated at $35^{\circ} \mathrm{C}$ at the wastewater treatment plant (wwtp) of Ede (NL). The screened $(<3 \mathrm{~mm})$ sewage came from a collecting system at the wwtp in Bennekom, the Netherlands. It was collected weekly and kept in a closed stirred tank at $5{ }^{\circ} \mathrm{C}$.

\subsubsection{A UASB-digester system}

\subsubsection{Effects of sludge recirculation test}

A pilot scale UASB-digester was operated to treat domestic sewage at $15{ }^{\circ} \mathrm{C}$ for a period of $372 \mathrm{~d}$. The influent flow rate was about $200 \mathrm{~L} / \mathrm{d}$. The following sludge recirculation rates were investigated: $1.8 \mathrm{~L} / \mathrm{d}, 5.2 \mathrm{~L} / \mathrm{d}$ and $25 \mathrm{~L} / \mathrm{d}$ for $210 \mathrm{~d}, 70 \mathrm{~d}$ and 92 
Table 2.1 The operational and design parameters of UASB-digester in the research.

\begin{tabular}{|c|c|c|}
\hline & UASB & Digester \\
\hline Total Height $\quad(\mathrm{m})$ & 1.15 & 1 \\
\hline Temperature $\left({ }^{\circ} \mathrm{C}\right)$ & 15 & 35 \\
\hline Diameter $(\mathrm{cm})$ & 23.5 & 23.5 \\
\hline Volume (1) & 50 & 38 \\
\hline $\operatorname{HRT}(\mathrm{d})$ & 0.25 & $21 / 7.3 / 1.5$ \\
\hline Effluent recirculation (\%) & 180 & - \\
\hline Up-flow velocity $(\mathrm{m} / \mathrm{h})$ & 0.5 & - \\
\hline Mixing condition (Rpm) & 0.2 & 84 \\
\hline
\end{tabular}

d respectively. Details of the UASB-digester system are given in Table 2.1. Effluent recirculation over the UASB was applied to increase the up-flow velocity from 0.26 $\mathrm{m} / \mathrm{h}$ to $0.5 \mathrm{~m} / \mathrm{h}$. The sludge bed height in the UASB reactor was manually controlled to be less than $80 \mathrm{~cm}$. The excess sludge was discharged from the height of $67 \mathrm{~cm}$. Sampling points on the UASB reactor were located at 11.5, 27, 47 and $67 \mathrm{~cm}$ height.

\subsubsection{Effects of HUST test}

Experiments about effects of HUST was performed after the study of effects of sludge recirculation rate. Sludge recirculation rate was fixed at $5.2 \mathrm{~L} / \mathrm{d}(2.6 \%$ of the $200 \mathrm{~L} / \mathrm{d}$ influent flow rate). Sludge return point from the digester to the UASB reactor was fixed at $5 \mathrm{~cm}$. The height of the UASB reactor was $100 \mathrm{~cm}$ and the height of the sludge bed was controlled at max. $70 \mathrm{~cm}$. A height of UASB sludge transfer (HUST) of 27, 47 and $67 \mathrm{~cm}$ was studied in three periods. During period 1 (sludge transfer point at $27 \mathrm{~cm}$ ), sludge circulation rate was temporarily increased to $25 \mathrm{~L} / \mathrm{d}$ (days 71-167), thus data were not shown. Effluent circulation over the UASB reactor was applied in period 1 and was stopped from period 2 onwards, which resulted in compaction of the sludge bed. Sludge circulation was temporarily stopped in period 2 (days 30-59) as the height of the UASB sludge bed was below the HUST. COD composition of the sewage is shown in Table 2.2. 
Table 2.2 Influent COD concentrations (in $\mathrm{mg} / \mathrm{L}$, standard deviation in brackets), $\mathrm{n}=$ number of samples

\begin{tabular}{cccccc}
\hline HUST $(\mathrm{cm})$ & $\mathrm{n}$ & COD total & COD suspended & COD colloidal & COD dissolved \\
\hline 27 & 12 & $605(133)$ & $282(868)$ & $82(32)$ & $241(50)$ \\
47 & 27 & $582(116)$ & $268(71)$ & $78(16)$ & $246(44)$ \\
67 & 6 & $714(189)$ & $377(117)$ & $64(11)$ & $272(88)$ \\
\hline
\end{tabular}

\subsubsection{Batch experiment}

Specific methanogenic activity (SMA) of the UASB sludge was determined in duplicate at $15{ }^{\circ} \mathrm{C}$. Serum bottles with a volume of $117 \mathrm{ml}$ were used in the test. The substrate was acetate with a starting concentration $1 \mathrm{~g} \mathrm{COD} / \mathrm{L}$. The volume of UASB sludge was $60 \mathrm{ml}$. No trace nutrition was added, assuming this was sufficiently present in the sludge samples for the whole test period. The contents and headspace were flushed with nitrogen. The bottles with demi water and without any biomass were used as blanks. The volume of demi water was the same as the volume of the sludge samples. All the samples were incubated at $15 \pm 1{ }^{\circ} \mathrm{C}$ in a shaker with $120 \mathrm{rpm}$ in the dark. The pressure in the bottles was checked twice per day by hand digital pressure meter with a needle.

The stability test of both the UASB and the digester sludge was similar to the SMA test. The test temperature was $35{ }^{\circ} \mathrm{C}$, and it was performed without addition of substrate. During the test, the anaerobic degradable compounds were converted to methane. The test was ended when no further methane production was observed (i.e. no further increase in pressure). High value in the results of stability test shows that high anaerobic biodegradable organic compound is in the sludge, which means less stable. The volatile suspended solids (VSS) and total suspended solids (TSS) of the UASB and digester sludge sample in SMA and stability tests are shown in Table 2.3 (in the study of effects of sludge recirculation rate). The UASB sludge samples were taken at $11.5 \mathrm{~cm}$ height from the bottom of UASB reactor.

For analysis of the gas composition a sample was taken with a $100 \mu 1$ syringe at the end of all the tests.

\subsubsection{Analysis}

Concentrations of nitrogen, methane, and carbon dioxide in the headspaces of the activity bottles were measured using a gas chromatograph (Interscience GC 8000 series) equipped with a thermal conductivity detector and Two columns (Molsieve 5A $50 \mathrm{~m} \times$ $0.53 \mathrm{~mm}$ for $\mathrm{N}_{2}$ and $\mathrm{CH}_{4}$ and Porabond Q $50 \mathrm{~m} \times 0.53 \mathrm{~mm}$ for $\mathrm{CO}_{2}$ ). Injector and 
Table 2.3 The VSS and TSS concentrations of UASB and digester sludge samples in the SMA and stability test (samples are duplicate and the standard deviation is in the brackets).

\begin{tabular}{ccccc}
\hline $\begin{array}{c}\text { Date } \\
\text { (since the } \\
\text { operation } \\
\text { started) }\end{array}$ & $\begin{array}{c}\text { VASS concentration } \\
\text { sludge }\end{array}$ & $\begin{array}{c}\text { Digester } \\
\text { sludge }\end{array}$ & $\begin{array}{c}\text { TSS concentration } \\
\text { sludge }\end{array}$ & $\begin{array}{c}\text { Digester } \\
\text { sludge }\end{array}$ \\
$($ day $)$ & $(\mathrm{g} / \mathrm{L})$ & $(\mathrm{g} / \mathrm{L})$ & $(\mathrm{g} / \mathrm{L})$ & $(\mathrm{g} / \mathrm{L})$ \\
\hline 161 & $7.8(-)$ & $6.3(-)$ & $11(-)$ & $9.5(-)$ \\
277 & $13.1(0.13)$ & $7.4(0.1)$ & $18.6(0.15)$ & $11.7(0.04)$ \\
307 & $11.5(0.04)$ & $6.7(0.01)$ & $17.5(0.08)$ & $10.4(0.06)$ \\
\hline
\end{tabular}

detector temperatures were respectively kept at 110 and $99{ }^{\circ} \mathrm{C}$, while oven temperature was $50{ }^{\circ} \mathrm{C}$.

COD was performed using DrLange tubes (type 514). VSS and TSS of the UASB sludge and the digester sludge were determined according to APHA (2005). The amount of dissolved methane in the UASB effluent was calculated using Henry's law.

\subsection{Results and discussion}

\subsubsection{Effects of sludge recirculation rate}

\subsubsection{COD removal efficiency}

Table 2.4 shows the average removal efficiency of total, suspended, colloid and dissolved COD during the three different sludge recirculation rates. The total COD removal efficiency reached the best result with the highest sludge recirculation rate of $25 \mathrm{~L} / \mathrm{d}$. Compared to the other two lower sludge recirculation rates of $5.2 \mathrm{~L} / \mathrm{d}$ and 1.8 $\mathrm{L} / \mathrm{d}$, the higher dissolved COD removal efficiency was the main contributor to the improved total COD removal efficiency. Based on the amount of sludge transferred to the digester and the anaerobic biodegradability of the sewage, the improved COD dissolved $_{\text {in }}$ removal efficiency mainly increased due to the transfer and conversion of dissolved COD in the digester. However, the larger amount of anaerobic biomass provided to the UASB also contributed to the higher dissolved COD removal efficiency. The total COD removal efficiency was lower than expected at all sludge recirculation rates, a possible explanation for this will be discussed later. 
Table 2.4 The summary of the suspended, colloid, dissolved and total COD removal efficiency, $\mathrm{n}$ is the numbers of samples (the efficiency was the average of all the samples).

\begin{tabular}{cccccc}
\hline $\begin{array}{c}\text { Sludge } \\
\text { recirculation } \\
\text { rate (L/d) }\end{array}$ & $\mathrm{n}$ & $\mathrm{COD}_{\text {total }}$ & $\mathrm{COD}$ suspended & $\mathrm{COD}$ colloid & COD dissolved \\
\hline 1.8 & 30 & $31.8 \pm 12.7$ & $61.9 \pm 17.7$ & $16.5 \pm 23.2$ & $6.3 \pm 8.6$ \\
5.2 & 7 & $32.2 \pm 8.1$ & $58.6 \pm 16.6$ & $19.1 \pm 16.5$ & $5.8 \pm 5.8$ \\
25 & 10 & $37.1 \pm 9.8$ & $58.1 \pm 21.2$ & $17.9 \pm 16.5$ & $17.1 \pm 11.5$ \\
\hline
\end{tabular}

\subsubsection{Stability and SMA of UASB-digester sludge}

The results of the stability and SMA tests of the UASB and the digester sludge are shown in Table 2.5. The results of stability test with UASB sludge at a recirculation rate of $1.8 \mathrm{~L} / \mathrm{d}$ shows that this sludge is relatively unstable, i.e. it still contains considerable amounts of biodegradable solids and accumulation of such solids in the sludge bed. Thus, although the total COD removal efficiency was similar compared to the UASBdigester system operation at a sludge recirculation rate of $5.2 \mathrm{~L} / \mathrm{d}$ as shown in Table 2.4, it was actually attributed to the organic solids accumulation. But the stability of UASB sludge was drastically improved after the sludge recirculation rate had increased from $1.8 \mathrm{~L} / \mathrm{d}$ to $5.2 \mathrm{~L} / \mathrm{d}$. The stability of the UASB sludge only improved 33 percent by further increasing the sludge recirculation rate from $5.2 \mathrm{~L} / \mathrm{d}$ to $25 \mathrm{~L} / \mathrm{d}$. The stability of the digester sludge at recirculation rate $25 \mathrm{~L} / \mathrm{d}$ remains same to $5.2 \mathrm{~L} / \mathrm{d}$. It meant the digester was still stable even at a high sludge recirculation rate $25 \mathrm{~L} / \mathrm{d}$. The SMA of the UASB sludge at $15{ }^{\circ} \mathrm{C}$ became higher at an increasing sludge recirculation rate. This can be attributed to an improved conversion of sewage solids to $\mathrm{CH}_{4}$ and biomass, and an increased supply of methanogens to the UASB sludge.

\subsubsection{Methane production}

The methane production as a fraction of total COD input and COD removed is shown in Table 2.6. It is clear that both $\mathrm{COD}_{\text {methane }} / \mathrm{COD}_{\text {in }}$ and $\mathrm{COD}_{\text {methane }} / \mathrm{COD}_{\text {removed }}$ were higher with an increasing sludge recirculation rate. The $\mathrm{COD} \mathrm{D}_{\text {methane }} / \mathrm{COD}_{\text {removed }}$ increased from 0.55 to 0.77 as sludge recirculation rate increased from $1.8 \mathrm{~L} / \mathrm{d}$ to 5.2 L/d. This confirmed that suspended COD accumulated (as discussed earlier) when operating at low circulation rate of $1.8 \mathrm{~L} / \mathrm{d}$, since suspended COD removal efficiencies were similar at these two sludge circulation rates (see Table 2.4). The $\mathrm{COD}_{\text {methane }} / \mathrm{COD}_{\text {removed }}$ reached 0.92 when the sludge recirculation rate increased to 25 L/d. It indicated a high anaerobic biodegradability of COD removed. Elmitwalli (2001) also reported that the anaerobic bio-degradability of suspended solids in domestic sewage was $78 \%$ at $30{ }^{\circ} \mathrm{C}$, however, without taking into consideration of dissolved

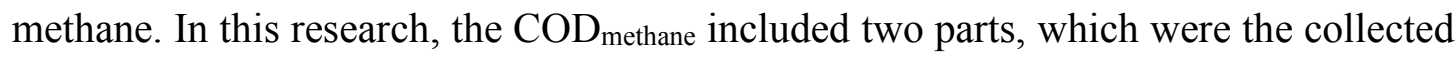
$\mathrm{CH}_{4}$ gas and the dissolved $\mathrm{CH}_{4}$ in the effluent of UASB-digester system. Assuming 
Table 2.5 The SMA of UASB sludge at $15^{\circ} \mathrm{C}$ and the stability of UASB and digester sludge at $35^{\circ} \mathrm{C}$.

\begin{tabular}{|c|c|c|c|}
\hline \multirow{2}{*}{$\begin{array}{l}\text { Sludge } \\
\text { recirculation } \\
\text { rate }(\mathrm{L} / \mathrm{d})\end{array}$} & \multicolumn{2}{|c|}{$\begin{array}{c}\text { Stability } \\
\text { (g-COD/g-COD) }\end{array}$} & \multirow{2}{*}{ 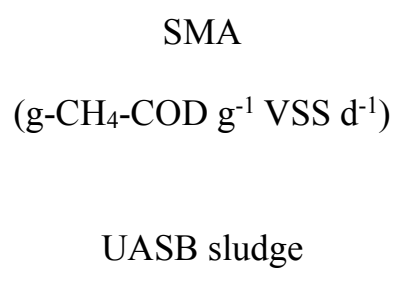 } \\
\hline & $\begin{array}{l}\text { UASB } \\
\text { sludge }\end{array}$ & $\begin{array}{l}\text { Digester } \\
\text { sludge }\end{array}$ & \\
\hline $1.8(0.9 \%)^{*}$ & 0.37 & - & 0.040 \\
\hline $5.2(2.6 \%)^{*}$ & 0.15 & 0.01 & $0.048(0.002)^{* *}$ \\
\hline $25(12.5 \%)^{*}$ & 0.10 & 0.01 & $0.067(0.003)^{* *}$ \\
\hline
\end{tabular}

* the sludge recirculation rate as percentage of the influent flow rate is given between brackets

** standard deviation; three samples were taken at the same time

that the dissolved $\mathrm{CH}_{4}$ was saturated in the effluent, it was calculated by Henry's law. However, the actual $\mathrm{COD}_{\text {methane }} / \mathrm{COD}_{\text {removed }}$ might be lower if $\mathrm{CH}_{4}$ was not saturated in the effluent.

Table 2.6 also shows the biogas production. A large part of the methane production (5.86 L-CH4 $/ \mathrm{d}$ according to Henry's law) in the UASB was dissolved in the effluent and combined with a low dissolved COD removal efficiency, the amount of biogas collected in the UASB was very low. It was higher after sludge recirculation rate increased from $5.2 \mathrm{~L} / \mathrm{d}$ to $25 \mathrm{~L} / \mathrm{d}$. This confirmed that, the high dissolved COD removal (in Table 2.4) at sludge recirculation rate $25 \mathrm{~L} / \mathrm{d}$ was indeed partially due to a large number of methanogens supplied from the digester to the UASB. It enhanced the conversion of dissolved COD to methane in the UASB. The bio-gas production in the digester significantly increased after the sludge recirculation rate had increased from $1.8 \mathrm{~L} / \mathrm{d}$ to $5.2 \mathrm{~L} / \mathrm{d}$. However, it did not rise any further at a sludge recirculation rate of $25 \mathrm{~L} / \mathrm{d}$. The reason might be that the bio-gas production of the digester is not only depended on the captured $\mathrm{COD}_{\text {suspended }}$ from the UASB sludge bed, but also its anaerobic degradability at $35{ }^{\circ} \mathrm{C}$.

Assuming that the suspended COD could be efficiently converted to methane, the methane production in the digester could be calculated in the following formula (1):

$$
\mathrm{V}_{\mathrm{CH} 4}=\mathrm{COD}_{\text {suspended }} \times \mathrm{Q}_{\text {influent }} \times \mathrm{D}_{\text {anaerobic bio-degradablity }} \times 0.35
$$

Where $\mathrm{VCH}_{4}$ is the methane production $(\mathrm{L} / \mathrm{d})$; $\mathrm{COD}_{\text {suspended }}$ is the concentration of suspended COD in the influent $(\mathrm{mg} / \mathrm{L})$; $\mathrm{Q}_{\text {influent }}$ is the influent flow rate of UASBdigester $(\mathrm{L} / \mathrm{d})$; $\mathrm{D}$ is the anaerobic bio-degradability of suspended solids, which was 0.78 in Elmitwalli's et al. (2001) research, but 0.5 was used in this work on the safe consideration. The methane production in theory should be about $10.5 \mathrm{~L} / \mathrm{d}$ in this 
Table 2.6 Methane production at different sludge recirculation rates (including gaseous and effluent saturated with dissolved methane).

\begin{tabular}{lccc}
\hline Sludge recirculation rate(L/d) & 1.8 & 5.2 & 25 \\
\hline $\mathrm{COD}_{\text {methane }} / \mathrm{COD}_{\text {in }}(\mathrm{g} / \mathrm{g})$ & 0.19 & 0.23 & 0.3 \\
$\mathrm{COD}_{\text {methane }} / \mathrm{COD}_{\text {removed }}(\mathrm{g} / \mathrm{g})$ & 0.55 & 0.77 & 0.92 \\
Bio-gas * digester $(\mathrm{L} / \mathrm{d})$ & 2.9 & 7.4 & 7.5 \\
Bio-gas ** UASB (L/d) & 0.31 & 0.37 & 1.22 \\
\hline
\end{tabular}

* the percentage of methane is $66 \%$

** the percentage of methane is $78 \%$

research. Assuming a $40 \mathrm{~kJ} / 1 \mathrm{CH}_{4}$ methane heat combustion and an efficiency of $80 \%$, about $336 \mathrm{~kJ} / \mathrm{d}$ heat could be obtained. It is enough to warm up the transferred sludge from the UASB to the digester from $15{ }^{\circ} \mathrm{C}$ to $35{ }^{\circ} \mathrm{C}$, whose recirculation rate is equivalent with $2-2.5 \%$ of the influent flow rate $(200 \mathrm{~L} / \mathrm{d})$.

The sludge recirculation rates $1.8 \mathrm{~L} / \mathrm{d}, 5.2 \mathrm{~L} / \mathrm{d}$ and $25 \mathrm{~L} / \mathrm{d}$ applied in this research represent $0.9 \%, 2.6 \%$ and $12.5 \%$ of influent flow rate respectively. Based on the biogas production, COD removal efficiency and the economy of sludge heating, a sludge circulation rate of $2.6 \%$ of the influent flow is recommended.

The COD concentrations of influent and effluent are shown in Fig. 2.2 for the different sludge recirculation rates. The dissolved COD concentration contributed from $46 \%$ to $53 \%$ to total influent COD and this was similar for the suspended COD. The dissolved COD removal efficiency increased about $12 \%$ after sludge recirculation rate increased from $5.2 \mathrm{~L} / \mathrm{d}$ to $25 \mathrm{~L} / \mathrm{d}$. However, it only somewhat improved the total COD removal efficiency. Thus, both the $\mathrm{COD}_{\text {methane }} / \mathrm{COD}_{\text {in }}$ and total $\mathrm{COD}$ removal efficiency were low even with $25 \mathrm{~L} / \mathrm{d}$ sludge recirculation rate. The dissolved COD was difficult to remove at $15{ }^{\circ} \mathrm{C}$ in the UASB-digester system and was the main part of the effluent (51$57 \%)$. A high contribution of dissolved COD (70\%) to total effluent COD was also reported by Álvarez et al. (2004), who also had a high fraction of dissolved COD in the influent (Fig. 2.2). Mahmoud et al. (2004), however, had a low fraction of influent dissolved COD, which resulted in a high total COD removal efficiency. This shows that the influent dissolved to total COD ratio is a key factor in achieving high COD removal efficiency in a UASB-digester system. Elmitwalli et al. (2001) also showed that the maximum conversion of the dissolved COD in domestic sewage was only $62 \%$ even at $30{ }^{\circ} \mathrm{C}$, this further emphasizes that the removal of dissolved COD is the main challenge in low temperature anaerobic treatment. It highlights that the lack of methanogens leads to a poor dissolved COD removal efficiency. Thus, longer SRT 


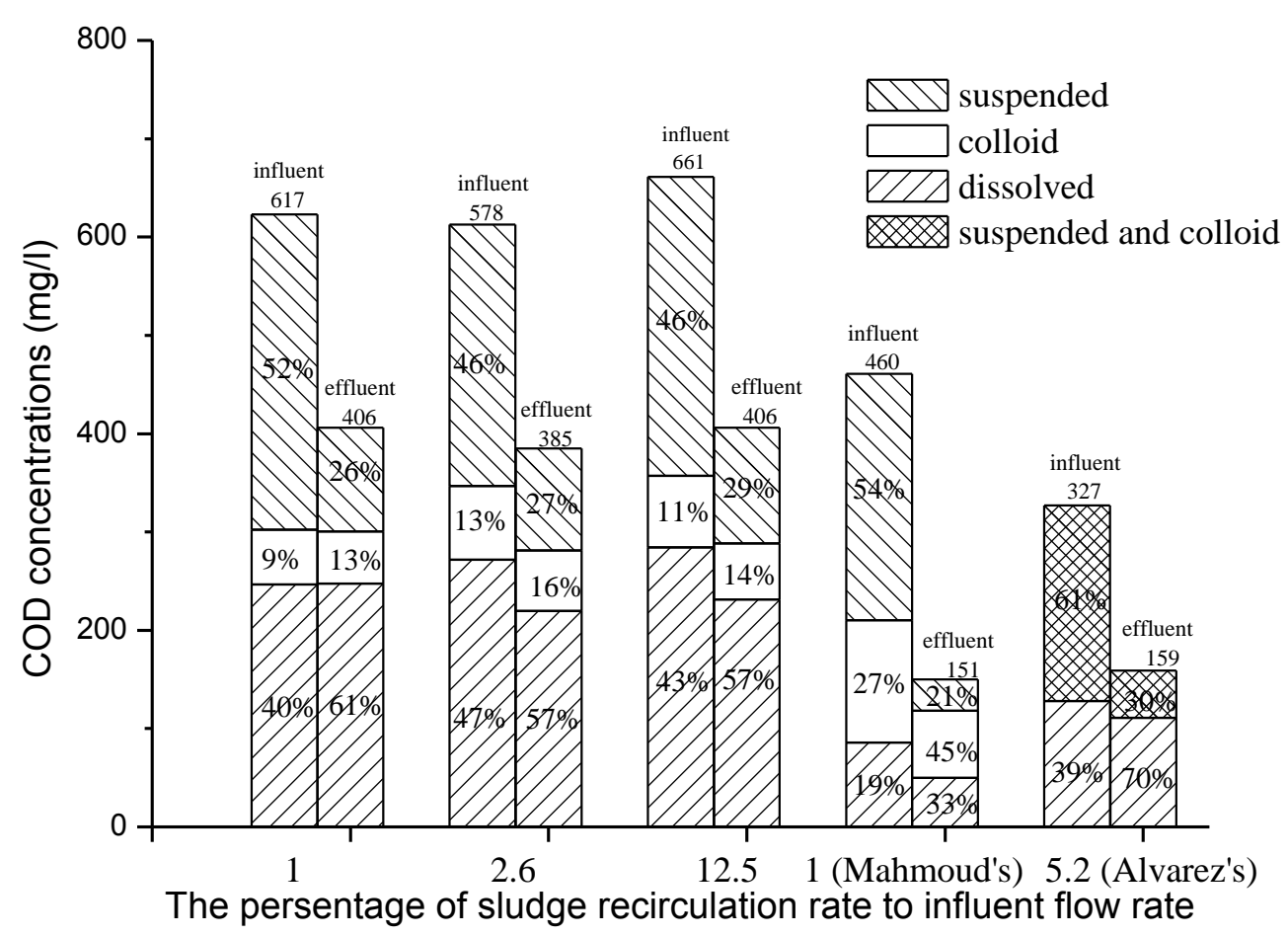

Fig. 2.2 Comparison of COD characteristics in this research and other researchers' during different percentage of sludge recirculation rate to influent flow rate.

(Gomec, 2010; Speece, 2008) and plenty of methanogens are required to enhance the removal efficiency of dissolved COD at low temperature.

\subsubsection{Effects of HUST}

\subsubsection{Increased UASB biogas production at higher sludge circulation point}

Increasing the HUST resulted in a clear increase in biogas production in the UASB reactor (Fig. 2.3). The average biogas productions at the height of 27,47 and $67 \mathrm{~cm}$ were $0.9,2.8$ and $2.8 \mathrm{~L} / \mathrm{d}$. The increased biogas production was the result of the increased methanogenic capacity (SMA $\times$ VSS) (as discussed later). In addition, it was also explained by a larger amount of dissolved COD originating from partial hydrolysis of the captured suspended COD, due to its longer retention in the UASB reactor. Gas production in the digester decreased with an increase in HUST: in period 1 biogas production was $7.1 \mathrm{~L} / \mathrm{d}$ in the digester. Increasing the height of UASB sludge transfer (HUST) to 47 and $67 \mathrm{~cm}$ (period 2 and 3) resulted in lower digester biogas productions of 3.2 and $3.7 \mathrm{~L} / \mathrm{d}$ respectively.

\subsubsection{Improved COD removal}

Fig. 2.4 shows that average suspended COD removal efficiencies were 52, 57 and $65 \%$ at the HUST of 27, 47 and $67 \mathrm{~cm}$. The improved efficiencies were probably because the UASB sludge bed was compact and high when transferring the sludge at high position, which enabled good capture of the suspended COD. Overall methane production from the removed COD decreased and was 74, 58 and $44 \%$, showing that suspended COD accumulated as the HUST increased (as confirmed by the increased 


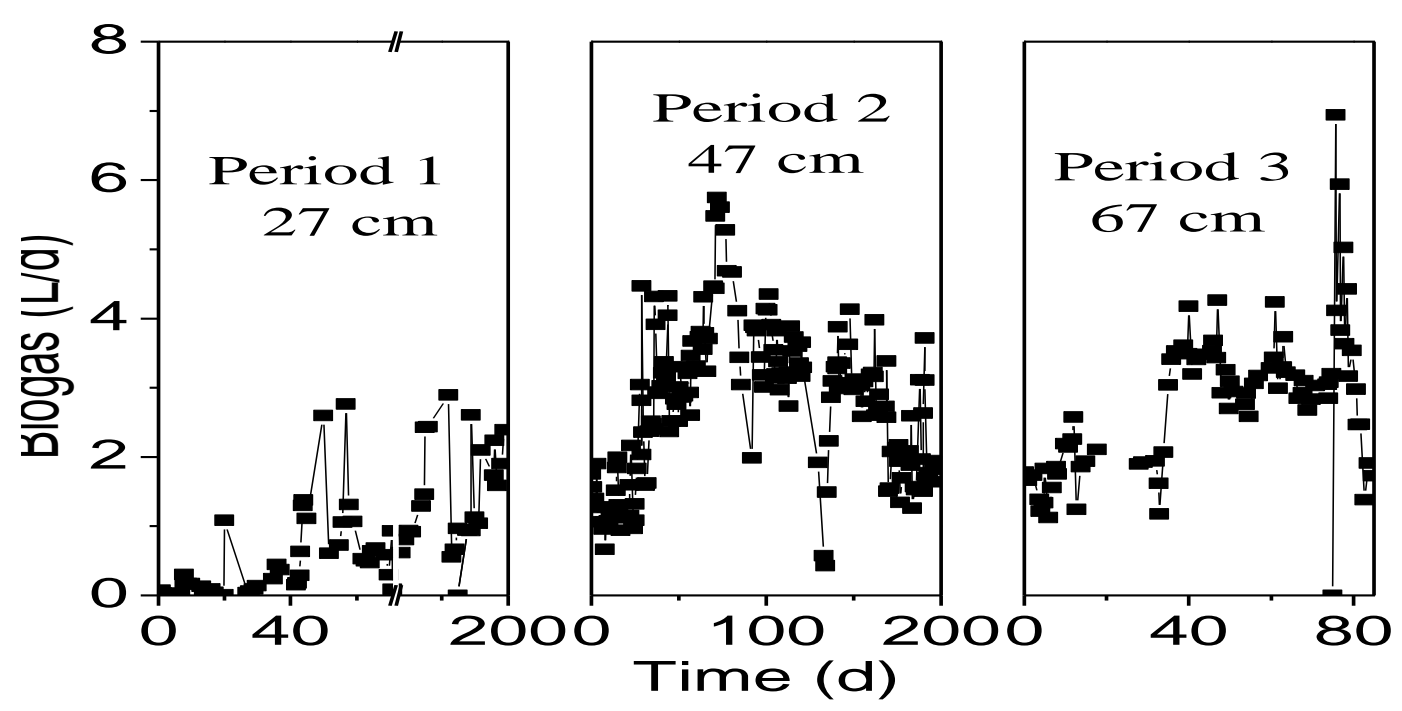

Fig. 2.3 Effects of HUST on biogas production of the UASB reactor in the system

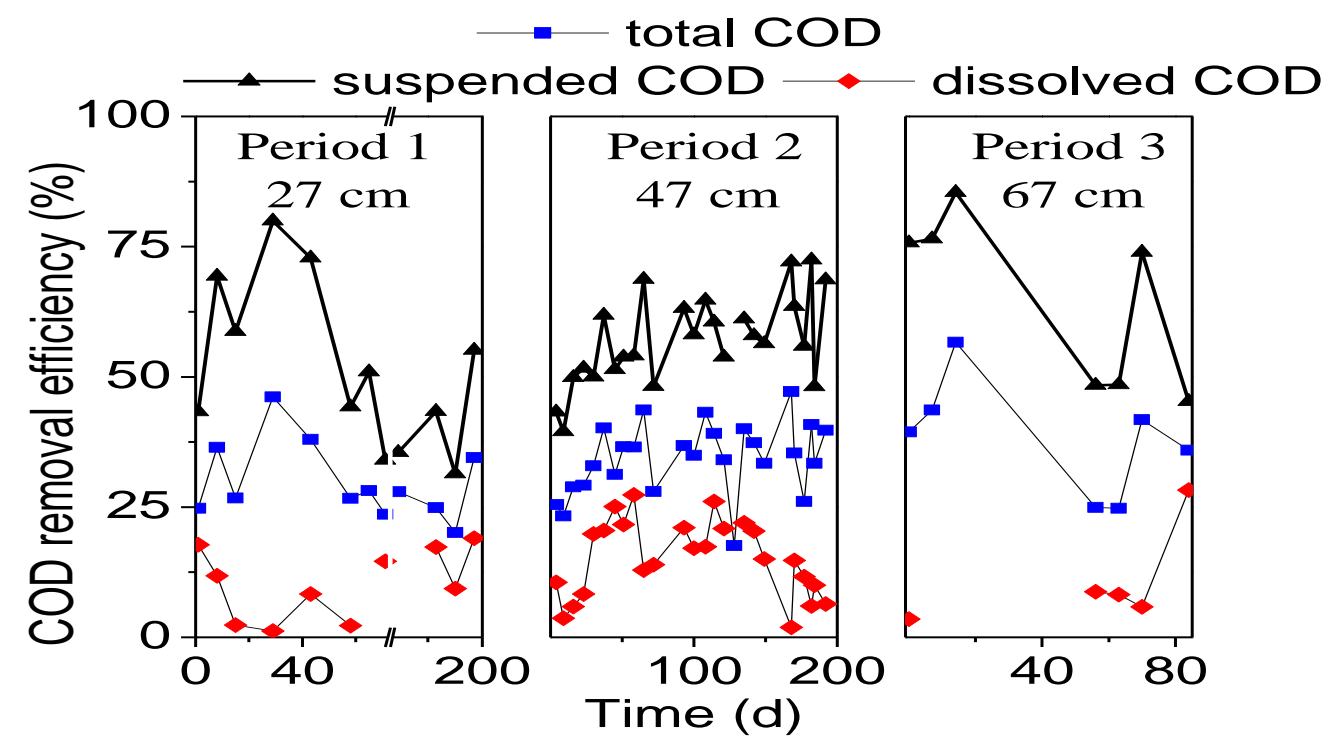

Fig. 2.4 Effects of HUST on COD removal efficiency of the UASB-digester

VSS concentrations, Table 2.7).

As a result, total COD removal efficiency increased to 30,34 and $38 \%$ at the studied HUSTs. Due to the slow accumulation, the system had not yet reached steady state yet. Longer term experiments will show whether this accumulated COD can be eventually efficiently converted to methane. The low total COD removal efficiencies in this study were due to the relatively low UASB reactor $(1 \mathrm{~m})$. Other, higher, reactors have shown higher total COD removal efficiencies of 51-66 \% (Mahmoud et al., 2004, Álvarez et al., 2004).

In period 2, dissolved COD removal efficiency initially increased, but later decreased again. This was caused by a net dissolved COD production, due to hydrolysis of the accumulated suspended COD in the UASB sludge bed. The methanogenic capacity of 
Table 2.7 Effects of HUST on VSS concentration and $\mathrm{SMA}_{15}{ }^{\circ} \mathrm{C}$ of the sludge in the UASBdigester (SMA unit: $\mathrm{mg} \mathrm{CH} \mathrm{CH}_{4} \mathrm{COD} /$ ( $\mathrm{g} \mathrm{VSS} \mathrm{d}$ ), standard deviation was in brackets)

\begin{tabular}{|c|c|c|c|c|c|c|c|c|c|}
\hline \multirow{2}{*}{$\begin{array}{c}\mathrm{H} \\
(\mathrm{cm})\end{array}$} & \multirow{2}{*}{$\begin{array}{l}\text { Time } \\
\text { d }\end{array}$} & \multicolumn{5}{|c|}{ VSS (g/L) } & \multirow{2}{*}{$\begin{array}{c}\text { Time } \\
\text { d }\end{array}$} & \multirow{2}{*}{$\begin{array}{c}\mathrm{SMA} \\
15^{\circ} \mathrm{C}\end{array}$} & \multirow{2}{*}{$\begin{array}{r}\text { VSS/ } \\
\text { TSS }\end{array}$} \\
\hline & & 11.5 & 27 & 47 & 67 & digester & & & \\
\hline 27 & 40 & 15 & $11(0.4)$ & 9 & $\begin{array}{c}8 \\
(0.1)\end{array}$ & $9(0.1)$ & 40 & $\begin{array}{c}33 \\
(1.0)\end{array}$ & 0.73 \\
\hline 47 & 199 & $\begin{array}{c}23 \\
(0.2)\end{array}$ & $\begin{array}{c}16 \\
(0.2)\end{array}$ & $\begin{array}{c}15 \\
(0.3)\end{array}$ & -- & $12(0.2)$ & 293 & $\begin{array}{c}30 \\
(1.0)\end{array}$ & 0.74 \\
\hline 67 & 63 & $\begin{array}{c}44 \\
(0.2)\end{array}$ & $\begin{array}{c}38 \\
(0.2)\end{array}$ & $\begin{array}{c}21 \\
(0.2)\end{array}$ & $\begin{array}{c}0.2 \\
(0.1)\end{array}$ & $7(0.5)$ & 476 & $\begin{array}{l}15 \\
(0)\end{array}$ & 0.72 \\
\hline
\end{tabular}

the sludge bed was still insufficient to convert this additional dissolved COD.

2.3.2.3 Higher solids concentration and improved methanogenic capacity of UASB reactor

Table 2.7 shows that VSS concentrations increased in the UASB reactor. It is hypothesized that suspended COD capture in the UASB reactor improved due to the higher solids concentration in the sludge bed, by allowing more adsorption onto the sludge. Additionally, due to (partial) hydrolysis of this captured suspended COD, the extracellular polymeric substances (EPS) may contribute to a better suspended COD capture. Confirmation of these hypotheses is part of ongoing research.

As shown in Table $2.7, \mathrm{SMA} 15^{\circ} \mathrm{C}$ of the UASB sludge decreased with increased HUST. However, total methanogenic capacity of the UASB reactor increased from 9.4 to 11.7 $\mathrm{g} \mathrm{CH}_{4}-\mathrm{COD} / \mathrm{d}$ as the HUST increased from 27 to $47 \mathrm{~cm}$, and was $10.5 \mathrm{~g} \mathrm{CH}_{4}-\mathrm{COD} / \mathrm{d}$ as the HUST further increased to $67 \mathrm{~cm}$.

\subsection{Conclusions}

Anaerobic treatment of domestic sewage at low temperature is feasible in a UASBdigester system. The removal of dissolved COD was limiting, especially at a high dissolved to total COD ratio in the influent.

Three sludge recirculation rates between $\operatorname{UASB}\left(15^{\circ} \mathrm{C}\right)$ and digester $\left(35^{\circ} \mathrm{C}\right)$ were tested, a higher sludge recirculation rate resulted in:

- Increase in total COD removal efficiency, mainly caused by the transfer of dissolved COD to the digester

- Improved conversion of removed COD to methane

- Improved stability of the sludge in the UASB 
Based on the potential energy available in the waste water, a sludge recirculation flow of 2-3 $\%$ of the influent flow is recommended.

A higher height of UASB sludge transfer (HUST) has a positive effect on the performance of a UASB-digester system treating sewage at $15^{\circ} \mathrm{C}$. It resulted in: 1) Higher biogas production rate in the UASB reactor; 2) Improved suspended COD removal efficiency; 3) Higher solids concentration in the UASB reactor and 4) Increased methanogenic capacity of the UASB sludge bed.

\section{Acknowledgements}

The authors thank the financial support of Chinese Scholarship Council for Zhang Lei. Tim Hendrickx and Christel Kampman were supported by the Technology Foundation STW (STW project 07736 ), the Netherlands. 


\section{Co-digestion to support low temperature anaerobic pretreatment of municipal sewage in a UASB-digester}

Lei Zhang, Tim L.G. Hendrickx, Christel Kampman, Hardy Temmink, Grietje Zeeman This chapter has been accepted for publication in Bioresource Technology, 2013, doi: 10.1016/j.biortech.2013.09.013. 


\begin{abstract}
The aim of this work was to demonstrate that co-digestion improves soluble sewage COD removal efficiency in treatment of low temperature municipal sewage by a UASB-digester system. A pilot scale UASB-digester system was applied to treat real municipal sewage, and glucose was chosen as a model co-substrate. Co-substrate was added in the sludge digester to produce additional methanogenic biomass, which was continuously recycled to inoculate the UASB reactor. Soluble sewage COD removal efficiency increased from 6 to $23 \%$, which was similar to its biological methane potential (BMP). Specific methanogenic activity of the UASB and of the digester sludge at $15^{\circ} \mathrm{C}$ tripled to a value respectively of 43 and $39 \mathrm{mg} \mathrm{CH} 4-\mathrm{COD} /(\mathrm{g} \mathrm{VSS} \cdot \mathrm{d})$. Methane production in the UASB reactor increased by more than $90 \%$ due to its doubled methanogenic capacity. Therefore, co-digestion is a suitable approach to support a UASB-digester for pretreatment of low temperature municipal sewage.
\end{abstract}




\subsection{Introduction}

Anaerobic biological treatment of municipal sewage has many advantages over aerobic treatment, such as lower operational cost, higher chemical oxygen demand (COD) loading rate, lower excess sludge production and energy recovery in the form of methane (Lettinga et al., 2001; Zeeman \& Kujawa-Roeleveld, 2011). So far, full scale anaerobic treatment of municipal sewage has been restricted to tropical areas (Chernicharo et al., 2009; Seghezzo et al., 1998), where the temperature of municipal sewage allows for sufficiently fast hydrolysis of complex organics and suspended solids. Lab scale research has shown the feasibility of low temperature $\left(6-15^{\circ} \mathrm{C}\right)$ application of anaerobic processes with easily biodegradable substrates (such as volatile fatty acids (VFAs), semi skimmed milk or nonfat dry milk) for both high and low strength waste waters (McKeown et al., 2009b; Rebac et al., 1999a). However, low temperature anaerobic treatment of municipal sewage still faces challenges. The main challenge is slow hydrolysis of complex and suspended organic material, and the other is slow growth of methanogens (Álvarez et al., 2008). A UASB-digester system may offer a solution for these challenges (Zhang et al., 2012, Álvarez et al. 2004, Mahmoud et al. 2004).

In this system, only the fraction of the municipal sewage that is transferred from a UASB reactor $\left(15^{\circ} \mathrm{C}\right)$ to a digester $\left(35^{\circ} \mathrm{C}\right)$ needs to be heated. The UASB reactor of this system is operated at cold conditions $\left(8-20{ }^{\circ} \mathrm{C}\right)$, while designed for summer conditions, in order to reduce its hydraulic retention time (HRT). As the loading rate is too high to allow for complete stabilization of entrapped suspended solids in the low temperature UASB reactor, these solids are transferred and stabilized in the sludge digester, which operates at $35{ }^{\circ} \mathrm{C}$. The stabilized sludge from the sludge digester is recycled to the UASB reactor to enhance methanogenic capacity for soluble COD removal at low temperatures. In this manner Mahmoud et al. (2004) achieved an average COD removal efficiency of $66 \%$ at $15{ }^{\circ} \mathrm{C}$ with municipal sewage of a low soluble COD fraction (19-24 \% of total COD). However, several authors have shown the average COD removal efficiency of the system decreased to only 37-46\% when treating municipal sewage with a considerably higher soluble COD fraction (33-44 \%), mainly caused by insufficient methanogenic activity in the UASB reactor (Álvarez et al., 2004; Zhang L. et al., 2011).

An interesting option to improve the performance of UASB-digester system for these types of municipal sewage is to add co-substrate to the sludge digester, which has not been tested yet. This option increases the organic loading on the digester, resulting in a higher methanogen production. This effect of co-digestion is similar to treating municipal sewage containing a high fraction of suspended COD, as it would also lead to a higher organic loading on the digester. As a result of co-digestion, the growth of methanogens will increase and, therefore, also the number of methanogens transferred from the digester to the UASB reactor. In this manner, the methanogenic activity of the 
Table 3.1 Operational and design parameters of the UASB-digester in this study

\begin{tabular}{ccc}
\hline Parameters & UASB & Digester \\
\hline Total liquid height $(\mathrm{m})$ & 1.1 & 0.8 \\
Diameter $(\mathrm{cm})$ & 23.5 & 23.5 \\
Working volume $(\mathrm{L})$ & 50 & 38 \\
HRT $(\mathrm{d})$ & 0.25 & 15 \\
Up-flow velocity $(\mathrm{m} / \mathrm{h})$ & 0.2 & - \\
& & 84 \\
Mixing condition $(\mathrm{rpm})$ & 0.2 & 35 \\
Temperature $\left({ }^{\circ} \mathrm{C}\right)$ & 15 & \\
\hline
\end{tabular}

UASB sludge is expected to increase, as well the soluble sewage COD removal in the UASB reactor.

The aim of this work was to demonstrate that co-digestion improves soluble sewage COD removal of low temperature municipal sewage anaerobic treatment. A pilot scale UASB-digester was studied in this research, and glucose was chosen as a model cosubstrate. The applicability of the UASB-digester pretreating low temperature municipal sewage in moderate climates will be discussed, as well as potential substrates for co-digestion.

\subsection{Materials and methods}

\subsubsection{UASB-digester with co-digestion}

The operational and design parameters of the UASB-digester system are given in Table 3.1. The sludge bed in the UASB reactor was manually kept below $80 \mathrm{~cm}$ by discharging sludge. Very slow mixing of the UASB reactor was performed by a rectangular stainless steel mixer rotating at $0.2 \mathrm{rpm}$ to prevent gas build-up and/or channel formation. The UASB sludge was transferred from a height of $67 \mathrm{~cm}$ to the middle of the digester, and the digester sludge was transferred from the bottom to a height of $27 \mathrm{~cm}$ of the UASB reactor. This sludge recirculation rate between UASB reactor and digester was $2.5 \mathrm{~L} / \mathrm{d}$, which corresponded to $1.25 \%$ of the influent flow rate of $200 \mathrm{~L} / \mathrm{d}$. The influent organic loading rate (OLR) of the UASB reactor was about $2.6 \mathrm{~kg} \mathrm{COD} /\left(\mathrm{m}^{3} \cdot \mathrm{d}\right)$. Excess sludge was discharged from the digester with an average amount of $1 \mathrm{~L} / \mathrm{d}$ when the sludge bed in the UASB reactor was higher than $70 \mathrm{~cm}$. At 
Table 3.2 Average concentration of influent COD (mg/L) and its fractions in three experimental periods. (period 1: without co-digestion; periods $2 \& 3$ : co-digestion was applied; n: number of the samples)

\begin{tabular}{lccccc}
\hline Period (days) & $\mathrm{n}$ & $\begin{array}{c}\text { Total COD } \\
(\text { CODt })\end{array}$ & $\begin{array}{c}\text { Suspended COD } \\
\text { (CODss) }\end{array}$ & Colloidal COD & Soluble COD \\
& & (CODcol) & (CODsol) \\
\hline (1) $-105 \ldots 0$ & 10 & $661 \pm 161$ & $351 \pm 98$ & $61 \pm 10$ & $249 \pm 77$ \\
(2) $\quad 0 \ldots 37$ & 5 & $727 \pm 141$ & $329 \pm 112$ & $79 \pm 28$ & $319 \pm 50$ \\
(3) $38 \ldots 189$ & 16 & $597 \pm 109$ & $285 \pm 67$ & $71 \pm 18$ & $241 \pm 45$ \\
\hline
\end{tabular}

the start of the experiments, the UASB-digester already had been operated for more than 3 years treating sewage from the same waste water treatment plant (WWTP) (Zhang et al. 2012). The biogas production of the UASB-digester was recorded by gas meters (Ritter, Germany).

The start of co-digestion was defined as day 0 , and the time before this as negative days. Experimental work was divided in three periods, and the duration of each period is shown in Table 3.2:

1. without co-digestion;

2. an average co-substrate addition of $8.2 \mathrm{~g}$ COD/ $\mathrm{d}(7 \%$ of the influent COD loading);

3. an average co-substrate addition of $16.6 \mathrm{~g} \mathrm{COD} / \mathrm{d}(14 \%$ of the influent COD loading).

Co-substrate was added batch-wise to the digester to avoid imposing a too high COD concentration. This addition was done four times per day, and the COD concentration in the digester after each co-substrate addition was calculated to increase by only 50 and $100 \mathrm{mg} \mathrm{COD} / \mathrm{L}$ in periods 2 and 3 respectively. All the additional COD was expected to be biodegraded in the digester, and not transferred to the UASB reactor. Therefore, the composition and amount of soluble sewage COD was not influenced by the co-substrate. Glucose was used as a model co-substrate and dosed as a solution of $100 \mathrm{~g} \mathrm{COD} / \mathrm{L}$.

\subsubsection{Sewage}

Screened $(<3 \mathrm{~mm})$ sewage was collected at the WWTP of Bennekom, the Netherlands. It was collected weekly and kept in a closed stirred tank at $5{ }^{\circ} \mathrm{C}$. Sewage $\mathrm{pH}$ was 7.67 $\pm 0.27(\mathrm{n}=33)$. The sewage sample for analysis was taken once a week, one day after the weekly sewage collection. The influent and effluent samples were collected after the influent pump and from the effluent tube respectively. The screened sewage was 
analysed for total sewage $\operatorname{COD}\left(\mathrm{COD}_{\mathrm{t}}\right), 8 \mu \mathrm{m}$ paper-filtered (Whatman grade 40, Germany) samples for particulate sewage $\mathrm{COD}\left(\mathrm{COD}_{\mathrm{p}}\right)$ and $0.45 \mu \mathrm{m}$ membranefiltered (Whatman FP 30/ $0.45 \mathrm{CA}$, Germany) samples for soluble sewage COD $\left(\mathrm{COD}_{\text {sol }}\right)$. In this study, suspended sewage $\mathrm{COD}\left(\mathrm{COD}_{\mathrm{ss}}\right)$ was defined as the fraction larger than $8 \mu \mathrm{m}$, whilst colloidal sewage COD was the fraction between 0.45 and 8 $\mu \mathrm{m}$. Correspondingly, these were calculated as $\mathrm{COD}_{\mathrm{ss}}=\mathrm{COD}_{\mathrm{t}}-\mathrm{COD}_{\mathrm{p}}$ and $\mathrm{COD}_{\text {col }}=\mathrm{COD}_{\mathrm{p}}-\mathrm{COD}_{\text {sol }}$.

\subsubsection{Specific methanogenic activity (SMA)}

The SMA of the UASB sludge and of the digester sludge were measured at $15^{\circ} \mathrm{C}$. The sludge sample and the substrate (sodium acetate) were added to a serum bottle $(120 \mathrm{ml})$. The initial substrate COD concentration of the mixed solution was $1 \mathrm{~g} / \mathrm{L}$. Anaerobic conditions were achieved by flushing the sample with nitrogen gas, and the samples were placed in a shaker at $120 \mathrm{rpm}$. The duration of an SMA test was 7 days. The increasing pressure in the serum bottle due to the biogas production was recorded by a hand-held pressure meter (GMH 3150, Germany). Calculation of the SMA was done as described by Zhang et al (2012).

One liter of the UASB sludge was sampled each month for an SMA test, after which the sample was disposed of. Sludge samples were collected from the UASB sampling point at a height of $47 \mathrm{~cm}$ and from the center of the digester. The methanogenic capacity of the UASB reactor was calculated by SMA of the sludge multiplied by the total amount of volatile suspended solids (VSS).

\subsubsection{Biological methane potential (BMP) of municipal sewage}

BMP tests were performed with screened sewage, $8 \mu \mathrm{m}$ filtered and $0.45 \mu \mathrm{m}$ filtered sewage. Two series of batch experiments were performed for each fraction with serum bottles of $120 \mathrm{~mL}$ incubated in shakers $(120 \mathrm{rpm})$ in the dark. In the first series, at $15^{\circ} \mathrm{C}$, digester sludge and UASB sludge were separately used as inoculum. The second series was inoculated only with digester sludge, but at two different temperatures of $15{ }^{\circ} \mathrm{C}$ and $35{ }^{\circ} \mathrm{C}$. For each series, about $95 \mathrm{~mL}$ of each fraction of wastewater and $5 \mathrm{~mL}$ of inoculum sludge were added to each serum bottle. The tests were conducted in duplicate. After adding fractionated sewage samples, the serum bottles were flushed with nitrogen gas. Trace nutrients were assumed to be sufficiently present in the municipal sewage samples. The tests lasted for 60 days, when biogas production stopped. COD and VFAs concentrations were determined for each fraction at the beginning and the end of the test.

\subsubsection{Analyses}

Total suspended solids (TSS), VSS and $\mathrm{pH}$ measurements were performed according to standard methods (APHA, 1998). COD was measured using cuvette tests (Hach Lange). VFAs samples were prepared with formic acid (1.5\% in measured sample) and 
analyzed by gas chromatography (GC) (HP 5890 GC) equipped with a $2 \mathrm{~m}$ x $6 \mathrm{~mm}$ x 2 mm glass column packed with Supelco support (100-200 mesh), coated with $10 \%$ Fluorad 431. Oven temperature was $130^{\circ} \mathrm{C}$, the carrier gas was nitrogen saturated with formic acid at a flow of $40 \mathrm{~mL} / \mathrm{min}$. Injector temperature was $200{ }^{\circ} \mathrm{C}$ and the flame ionization detector was $280{ }^{\circ} \mathrm{C}$. Sample size was $1 \mu \mathrm{L}$.

Concentrations of nitrogen, methane, and carbon dioxide in the headspaces of the batch experiments and in the biogas produced by the UASB-digester were measured using a GC (Interscience GC 8000 series) equipped with a thermal conductivity detector and two columns (Molsieve 5A $50 \mathrm{~m} \times 0.53 \mathrm{~mm}$ for nitrogen and methane and Porabond $\mathrm{Q}$ $50 \mathrm{~m} \times 0.53 \mathrm{~mm}$ for $\mathrm{CO}_{2}$ ). Temperatures of injector, detector and oven were 110, 99 and $50{ }^{\circ} \mathrm{C}$ respectively.

The tested soluble sewage COD concentration did not include dissolved methane COD. Dissolved methane concentration in the effluent of the UASB reactor was determined separately twice per month in triplicate samples. For each sample, about $5.3 \mathrm{~g} \mathrm{NaCl}$ was added into a $50 \mathrm{~mL}$ tube first. The vial was closed with a stopper. Before adding effluent sample into the vial, about $20 \mathrm{~mL}$ of air was extracted using a syringe with a needle. About $15 \mathrm{~mL}$ of the effluent was slowly injected into the vial. This tube was shaken well to fully mix the salt with the sample. After 30 minutes of settling and reaching equilibrium (transfer of methane to the gas phase), the final pressure was measured by a hand-held digital pressure meter (GMH 3150, Germany) with a needle (the precision was up to 1 mbar). The gas composition was analysed after pressure measurement. The amount of dissolved methane in $\mathrm{g} \mathrm{CH}_{4}-\mathrm{COD}$ was calculated by the following formula:

$$
\mathrm{CH}_{4} \text { dissolved }=\mathrm{P} \cdot \mathrm{C} \cdot \mathrm{V} \cdot 64 /(\mathrm{R} \cdot \mathrm{T})
$$

With $\mathrm{P}$ the final pressure of headspace in the sample tube $(\mathrm{kPa}) ; \mathrm{C}$ the percentage of methane in the biogas; $\mathrm{V}$ the volume of the headspace in the tube $(\mathrm{L}) ; \mathrm{R}=8.314$ $\mathrm{J} /(\mathrm{mol} \cdot \mathrm{K}) ; \mathrm{T}=293 \mathrm{~K} .64$ is the conversion factor between mole of $\mathrm{CH}_{4}$ and $\mathrm{g} \mathrm{CH}_{4}-$ COD.

\subsection{Results and discussion}

\subsubsection{Characteristics of sewage COD}

Total and fractionated COD concentrations (suspended, colloidal and soluble COD) of the sewage are shown in Table 3.2. The average total COD concentration in this study was between 597 and $727 \mathrm{mg} \mathrm{COD} / \mathrm{L}$. The COD mainly consisted of suspended (45$53 \%$ ) and soluble COD (38-44 \%). The fraction of the latter was much higher than 19$24 \%$ reported by Mahmoud et al. (2004) who also investigated a UASB-digester system. The colloidal fraction in the influent was only small (10-12\%) and therefore will not be further included in the results section. 


\subsubsection{Sewage COD removal efficiency}

As shown in Fig. 3.1a, soluble sewage COD removal efficiency of the UASB-digester

Table 3.3 BMP of the sewage fractions: total, suspended and soluble COD. Digester or UASB sludge was used as inoculum. Results are the average of duplicate samples ( \pm standard deviation).

\begin{tabular}{cccccc}
\hline $\begin{array}{c}\text { Day of } \\
\text { sewage } \\
\text { sampling }\end{array}$ & $\begin{array}{c}\text { Inoculum } \\
\text { sludge }\end{array}$ & $\begin{array}{c}\text { Temperature } \\
\left({ }^{\circ} \mathrm{C}\right)\end{array}$ & $\begin{array}{c}\text { Total COD } \\
(\%)\end{array}$ & $\begin{array}{c}\text { Suspended } \\
\text { COD }\end{array}$ & $\begin{array}{c}\text { Soluble } \\
\text { COD }\end{array}$ \\
\hline \multirow{2}{*}{79} & Digester & 15 & $38 \pm 3$ & $52 \pm 3$ & $17 \pm 1$ \\
& UASB & & $34 \pm 2$ & $45 \pm 2$ & $17 \pm 2$ \\
136 & Digester & 15 & $47 \pm 3$ & $44 \pm 8$ & $32 \pm 3$ \\
& & 35 & $56 \pm 4$ & $69 \pm 1$ & $46 \pm 5$ \\
\hline
\end{tabular}

increased after applying co-digestion. The average soluble sewage COD removal efficiency was only $6.1 \%$ before co-digestion (period 1), but this increased to $13.2 \%$ after co-digestion started in period 2 and to $23.0 \%$ in period 3, which was in the same range as the BMP of soluble sewage COD at $15{ }^{\circ} \mathrm{C}$ (Table 3.3). A similar soluble COD removal efficiency of $30 \%$ in the UASB-digester system was found by Mahmoud et al. (2004), who also treated municipal sewage but with a much lower soluble COD fraction. The observed week to week variation in the soluble COD removal efficiency could be explained by changes in sewage composition and its BMP (17-32\% for soluble COD, see Table 3.3). A similar low BMP of soluble COD of $27.0 \%$ at $15^{\circ} \mathrm{C}$ was reported by Elmitwalli et al. (2001). Since not all the soluble sewage COD was anaerobically biodegradable, the effluent contained a high residual soluble COD concentration. Aerobic post treatment will, therefore, be required when implementing this technology at a full scale.

In this study, acetate was the dominant VFAs in both the influent and effluent of the UASB-digester. The average percentages of acetate in the VFAs fraction were $83 \%$ and $86 \%$ respectively for the influent and effluent. The other VFAs consisted of propionate $(17 \%$ and $14 \%)$ in the influent and effluent respectively, both corresponding to an average of $11 \mathrm{mg} \mathrm{COD} / \mathrm{L}$. The introduction of co-digestion in the digester changed the UASB reactor from a net producer of acetate to a net consumer of acetate (Fig.3.1b). In period 1, without co-digestion, the average acetate concentration 

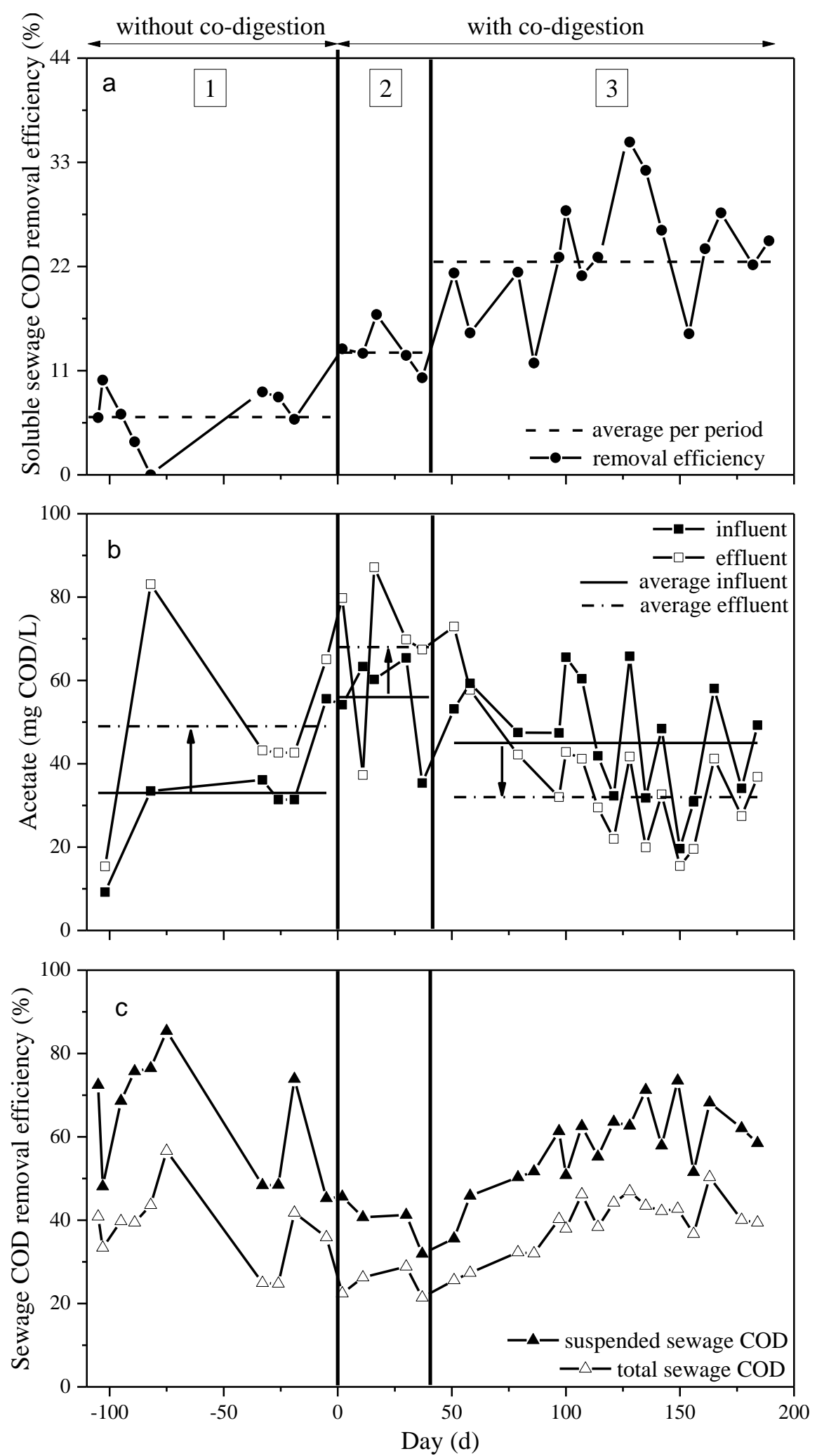

Fig. 3.1 Sewage COD removal efficiency of the UASB digester pretreating municipal sewage in 3 periods. 1 without co-digestion; $2 \& 3$ with co-digestion, 8.2 and $16.6 \mathrm{~g} \mathrm{COD} / \mathrm{d}$ was added into the sludge digester respectively.

( All removal efficiencies excluded glucose-COD.

a: sewage soluble COD removal efficiency; b: acetate concentration;

c: suspended COD and total sewage COD removal efficiency) 
in the effluent increased by $17 \mathrm{mg}$ COD/L compared to the influent. Similarly, in period 2 the average acetate concentration in the effluent still was $12 \mathrm{mg} \mathrm{COD} / \mathrm{L}$ higher than that in the influent. The net acetate production could be explained by acidification of influent soluble sewage COD, and/or (partial) hydrolysis and acidification of the influent suspended sewage COD. In combination with an insufficient methanogenic capacity of the UASB reactor, this resulted an increased acetate concentration. Glucose or produced VFAs transferred from the digester was considered negligible. This was confirmed by VFAs concentration measurements in the supernatant of the digester sludge in period 3, which were 22 and $2 \mathrm{mg} \mathrm{COD} / \mathrm{L}$, respectively 1 and $3 \mathrm{~h}$ after a glucose batch addition. In period 3, the average effluent acetate concentration was lower than that in the influent. It remained low with an average of $31 \mathrm{mg} \mathrm{COD} / \mathrm{L}$ after day 60 , with a minimum value of $15.5 \mathrm{mg} \mathrm{COD} / \mathrm{L}$. These decreased effluent acetate concentrations could be explained by an increased methanogenic capacity of the UASB reactor as a result of co-digestion, as will also be shown in the next paragraph.

In addition to the improved soluble sewage COD removal efficiency, applying codigestion also contributed to an increased suspended sewage COD removal efficiency (all the removal efficiencies excluded the glucose-COD). The high suspended sewage COD removal efficiencies in the beginning of period 1 without co-digestion were mainly because of accumulation in the sludge bed (Fig.3.1c). This was confirmed by a low methane production (see Section 3.3.4) in this period. The suspended sewage COD removal efficiencies decreased later in period 1, when the sludge bed could not accumulate more suspended COD. As can be seen from Fig.3.1c, after adding cosubstrate, suspended sewage COD removal efficiency maintained stable in period 2 and started to increase at the beginning of period 3. This increase may be explained by a higher extracellular polymer substances (EPS) production in the digester caused by adding glucose (Miqueleto et al., 2010; Miqueleto et al., 2005), though this was not verified in this study. In the UASB reactor, a higher EPS content may contribute to better suspended solids capture in the sludge bed. The suspended sewage COD removal did not yet clearly increase in period 2, as the (hypothesized) EPS production might not have been sufficient. The higher glucose addition in period 3 may also have resulted in a faster establishment of a new equilibrium between EPS production and suspended COD removal efficiency.

Total sewage COD removal efficiency clearly improved in period 3, which increased from $27 \%$ to $50 \%$. The achieved total and the suspended sewage COD removal efficiencies were $42 \%$ and $62 \%$ respectively, from day 100 onwards. Soluble sewage COD removal contributed for almost a quarter to total sewage COD removal efficiency. The low BMP of soluble sewage COD, as previously discussed and shown in Table 3.3, and its high fraction ( $40 \%$ ) in the sewage explained the low total sewage COD removal efficiency.

\subsubsection{Methanogenic capacity UASB}

Details of sludge samples taken from the UASB and digester are given in Table 3.4. 
Table 3.4 Characteristics of the UASB (sampling point at $47 \mathrm{~cm}$ ) and of the digester sludge. Results show the average of duplicate samples ( \pm standard deviation).

\begin{tabular}{|c|c|c|c|c|c|c|c|c|}
\hline \multirow{2}{*}{ Day } & \multicolumn{2}{|c|}{ VSS concentration $(\mathrm{g} / \mathrm{L})$} & \multicolumn{2}{|c|}{ TSS concentration $(\mathrm{g} / \mathrm{L})$} & \multicolumn{2}{|c|}{ VSS/TSS } & \multicolumn{2}{|c|}{$\mathrm{CODt} / \mathrm{VSS}$} \\
\hline & UASB & Digester & UASB & Digester & UASB & Digester & UASB & Digester \\
\hline-12 & $21.3 \pm 0.2$ & $6.9 \pm 0.5$ & $29.6 \pm 0.2$ & $10.1 \pm 0.5$ & 0.72 & 0.68 & 2.0 & 1.9 \\
\hline 41 & $14.1 \pm 0.3$ & $11.8 \pm 0.4$ & $21.5 \pm 0.3$ & $18.8 \pm 0.5$ & 0.66 & 0.63 & 1.9 & 1.9 \\
\hline 119 & $17.6 \pm 0.3$ & $5.0 \pm 0.2$ & $26.9 \pm 0.2$ & $8.2 \pm 0.2$ & 0.66 & 0.60 & 1.9 & - \\
\hline 147 & $15.0 \pm 0.1$ & $6.0 \pm 0.1$ & $22.6 \pm 0.1$ & $9.6 \pm 0.1$ & 0.66 & 0.62 & 2.1 & 2.0 \\
\hline 182 & $20.5 \pm 0.2$ & $6.4 \pm 0.4$ & $28.6 \pm 0.3$ & $9.2 \pm 0.4$ & 0.72 & 0.70 & 2.4 & 2.2 \\
\hline
\end{tabular}

SMA values at $15{ }^{\circ} \mathrm{C}$ determined with these values are shown in Table 3.5, as well as calculated methanogenic capacities. The results in Table 3.5 show a clear increase in methanogenic capacity of the UASB reactor after co-digestion was introduced. The capacity almost doubled from $11.3 \mathrm{~g} \mathrm{CH}_{4}-\mathrm{COD} / \mathrm{d}$ in period 1 to $20.0 \mathrm{~g} \mathrm{CH}_{4}-\mathrm{COD} / \mathrm{d}$ in period 3. This increase was mainly caused by the improved SMA of the UASB sludge, which almost tripled from $15 \mathrm{mg} \mathrm{CH} 4-\mathrm{COD} /(\mathrm{g} \mathrm{VSS} \cdot \mathrm{d})$ in period 1 to $43 \mathrm{mg} \mathrm{CH}_{4}-$ $\mathrm{COD} /(\mathrm{g}$ VSS $\cdot \mathrm{d}$ ) in period 3 (see Table 5 ). The SMA of the digester sludge also increased to $39 \mathrm{mg} \mathrm{CH}$-COD/(g VSS·d) in period 3, almost three times as high as the one in period 1 without co-digestion. The relationship between the amount of glucose addition and methanogenic fraction of the sludge still needs further investigation.

\subsubsection{Methane production}

The results in Table 3.6 show that the methane production in the UASB reactor increased from $11.1 \mathrm{~g} \mathrm{CH}_{4}-\mathrm{COD} / \mathrm{d}$ in period 1 without co-digestion to $19.3 \mathrm{in}$ period 3 with co-digestion, which was an increase of more than $90 \%$. This was in agreement with the increased methanogenic capacity of the UASB reactor (11.1 in period 1 and $18.9 \mathrm{~g} / \mathrm{d}$, the average in period 3). The measured total methane production (gaseous + soluble) in the UASB reactor closely matched the calculated methanogenic capacity, which indicated that the UASB reactor was operating under non-substrate limiting conditions. This again confirmed that the number of methanogens in the UASB reactor was the limiting factor for low temperature municipal sewage treatment. 
Table 3.5 SMA at $15^{\circ} \mathrm{C}$ of the sludge of the UASB-digester, VSS in the UASB reactor and methanogneic capacity of the UASB reactor in three periods (tests were performed in duplicate, Methanogenic capacity $=$ SMA $($ UASB $) \times$ VSS. $)$

\begin{tabular}{|c|c|c|c|c|c|}
\hline \multirow{2}{*}{\multicolumn{2}{|c|}{$\begin{array}{l}\text { Period } \\
\text { (day) }\end{array}$}} & \multicolumn{2}{|c|}{$\begin{array}{c}\text { SMA } \\
\left(\mathrm{mg} \mathrm{CH}_{4}-\mathrm{COD} / \mathrm{g} \mathrm{VSS} \cdot \mathrm{d}\right)\end{array}$} & \multirow{2}{*}{$\begin{array}{c}\text { Total VSS (g) } \\
\text { UASB }\end{array}$} & \multirow{2}{*}{$\begin{array}{l}\text { Methanogenic Capacity } \\
\qquad \begin{array}{c}\left(\mathrm{g} \mathrm{CH}_{4}-\mathrm{COD} / \mathrm{d}\right) \\
\mathrm{UASB}\end{array}\end{array}$} \\
\hline & & UASB & Digester & & \\
\hline (1) & -12 & $15 \pm 0^{\mathrm{a}}$ & $12 \pm 0^{\mathrm{a}}$ & 753 & 11.3 \\
\hline (2) & 41 & $35 \pm 2$ & $23 \pm 1$ & 403 & 14.1 \\
\hline (3) & 119 & $37 \pm 3$ & $18 \pm 3$ & 522 & 19.3 \\
\hline \multicolumn{2}{|c|}{147} & $43 \pm 0$ & $39 \pm 6$ & 407 & 17.5 \\
\hline \multicolumn{2}{|c|}{182} & $36 \pm 0.4$ & $-b$ & 556 & 20.0 \\
\hline
\end{tabular}

${ }^{a}$ performed in triplicate

${ }^{\mathrm{b}}$ data not available

The dissolved methane concentration in the effluent of the system was found to be 50$60 \%$ of the saturation value calculated with Henry's law. This relatively low percentage may have been caused by a higher ionic strength in the sewage compared to distilled water (Souza et al., 2011).

Based on the soluble sewage COD load and the average BMP of $25 \%$ at $15{ }^{\circ} \mathrm{C}$ (Table $3.3)$, the maximum potential methane production from the influent soluble sewage COD in the UASB reactor would be $12.5,16.0$ and $12.1 \mathrm{~g} \mathrm{CH}_{4}-\mathrm{COD} / \mathrm{d}$ in periods 1,2 and 3 respectively. The measured methane production in period 3 was much higher than this maximum potential. This indicated that in period 3 an additional $7.2 \mathrm{~g}(=19.3-$ 12.1) $\mathrm{CH}_{4}-\mathrm{COD} / \mathrm{d}$ was produced via (partial) hydrolysis of the suspended sewage COD captured in the sludge bed, even at a temperature as low as $15^{\circ} \mathrm{C}$. Most likely this also took place in periods 1 and 2, but this could not be confirmed according to these calculations.

Methanisation of sewage COD in the digester improved from $6.3 \mathrm{~g} \mathrm{CH}_{4}-\mathrm{COD} / \mathrm{d}$ in period 1 to more than $8.8 \mathrm{~g} / \mathrm{d}$ in period 3 (Table 3.6). This can only be explained by an improved capture and transfer of suspended COD from the UASB reactor to the digester. Average methanisation of influent total sewage COD increased from $12.5 \%$ to mor 
Table 3.6 Average methane production in the UASB-digester before and after co-digestion ("based on SMA"= SMA x VSS)

\begin{tabular}{|c|c|c|c|c|c|c|c|c|}
\hline \multirow[t]{3}{*}{ Period } & \multicolumn{4}{|c|}{$\begin{array}{l}\text { Methane production in the UASB reactor } \\
\qquad\left(\mathrm{g} \mathrm{CH}_{4}-\mathrm{COD} / \mathrm{d}\right)\end{array}$} & \multicolumn{3}{|c|}{$\begin{array}{l}\text { Methane production in the digester } \\
\qquad\left(\mathrm{g} \mathrm{CH}_{4}-\mathrm{COD} / \mathrm{d}\right)\end{array}$} & \multirow[t]{2}{*}{$\begin{array}{l}\text { Influent COD } \\
\text { load (g COD/d) }\end{array}$} \\
\hline & & Measured & & Calculated & Measured & & ulated & \\
\hline & Gaseous & Effluent dissolved & Total & Based on SMA & Total & From Glucose & From Sewage COD & \\
\hline 1 & 5.0 & 6.1 & 11.1 & 11.3 & 6.3 & 0 & 6.3 & 139.0 \\
\hline 2 & 7.1 & 7.0 & 14.1 & 14.1 & 14.2 & $<8.2^{\mathrm{a}}$ & $>6.0$ & 145.0 \\
\hline 3 & 10.3 & 9.0 & 19.3 & $18.9^{b}$ & 25.4 & $<16.60^{\mathrm{a}}$ & $>8.8$ & 119.5 \\
\hline
\end{tabular}

${ }^{a}$ will be lower due to growth

$\mathrm{b}$ average in period 3 


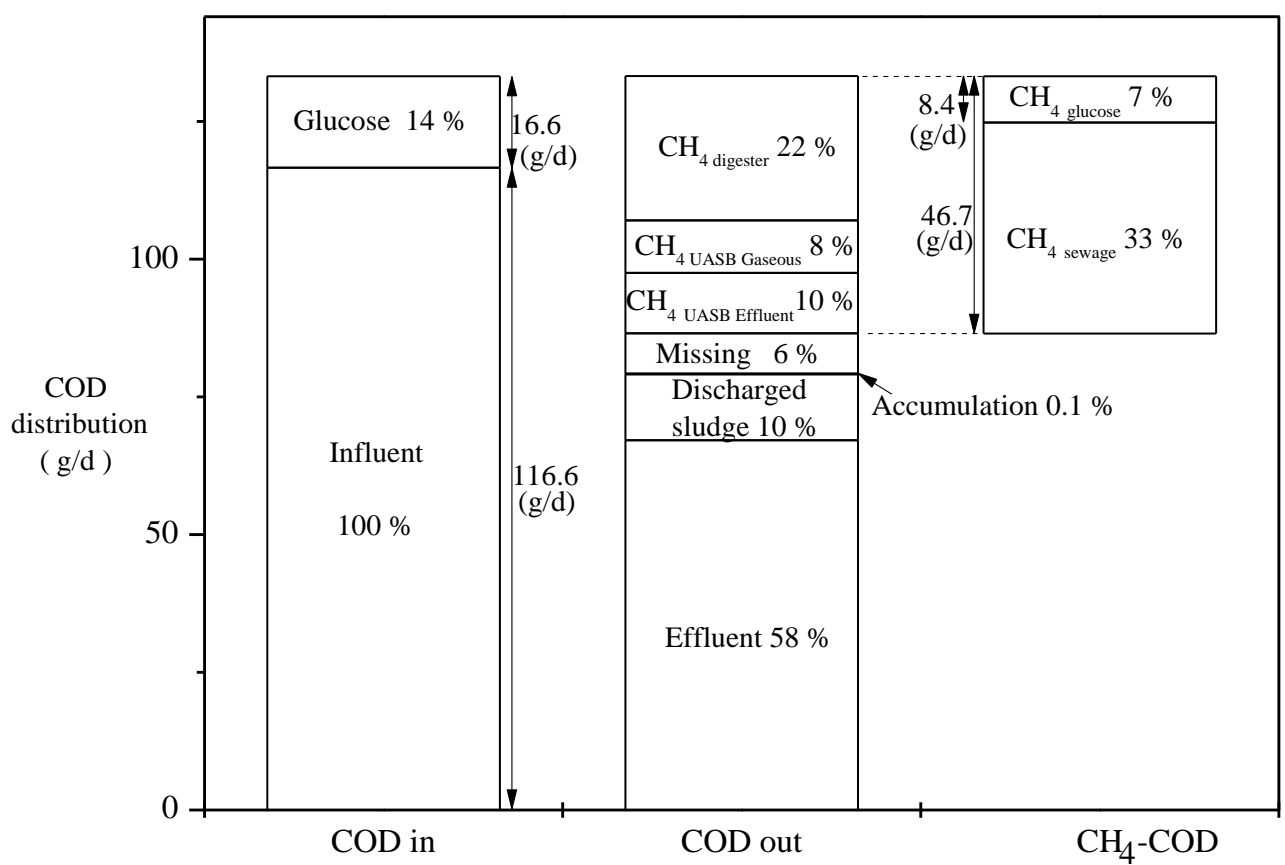

Fig. 3.2 COD balance of the UASB-digester pretreating municipal sewage at $15^{\circ} \mathrm{C}$ in period 3 of codigestion study (day 100-189); COD in has two parts: 1) municipal sewage (100\%); 2) co-substrate (glucose, $14 \%$ ). The specified methane production (sewage, glucose) assumes a biomass yield of $0.5 \mathrm{~g}$ biomass-COD/g glucose-COD converted. All percentages are relative to the influent sewage COD.

than $13.8 \%$, and later to more than $24.4 \%$ in periods 1,2 and 3 respectively (COD loading and methane production from the added glucose were excluded in this calculation).

The COD mass balance of the UASB-digester system in the stable phase of period 3 (day 100-189) is shown in Fig.3.2. The influent COD loading was used as $100 \%$, which enabled other COD fractions to be compared with the influent. The average methane production was $46.7 \mathrm{~g} \mathrm{CH}_{4}-\mathrm{COD} / \mathrm{d}$. This included the methane produced from glucose, which was $8.4 \mathrm{~g} \mathrm{CH}_{4}-\mathrm{COD} / \mathrm{d}$, assuming a yield of $0.5 \mathrm{~g}$ biomass-COD $/ \mathrm{g}$ glucose-COD converted (Speece, 2008). As the sewage COD load on the system was $116.6 \mathrm{~g} \mathrm{COD} / \mathrm{d}$, the sewage methanisation was $33 \%$ during day 100-189.

The average BMP of the sewage fed to the UASB-digester system was calculated to be $42-46 \%$, using the average COD concentrations given in Table 3.2, a biodegradability of suspended sewage $\mathrm{COD}$ at $35^{\circ} \mathrm{C}(69 \%)$, and the average biodegradability of soluble sewage COD at $15{ }^{\circ} \mathrm{C}(25 \%)$. This implied that the UASB-digester achieved about $75 \%$ of the maximum potential methane production.

\subsubsection{General Discussion}

Co-digestion successfully improved the performance of the UASB-digester pretreating municipal sewage with a high soluble COD fraction at $15^{\circ} \mathrm{C}$. The amount of added cosubstrate-COD was about $14 \%$ of influent COD load. A further improvement could 
potentially be achieved, but the amount of co-substrate was not yet optimised. At lower temperatures of the municipal sewage, a higher amount of co-substrate may be required, to compensate for a further drop in specific methanogenic activity. However, this still needs to be investigated.

In practice, several resources could be used as substrates, provided they are biodegradable, have a low N/COD ratio and promote EPS production. To avoid additional costs of the transport of co-substrate, excess sludge from aerobic post treatment after the UASB-digester may be used as a local and practical co-substrate. This would amount to about $24 \%$ on influent basis, which is higher than the cosubstrate dose used in this study (14\%), but its biodegradability may only be 40-50\%. As other substrates are (much) more complex than glucose, their practical applicability needs to be tested, e.g. for their contribution to the beneficial higher EPS production and the amount of inert material introduced to the UASB-digester system. Also, the number of other co-substrates must be controlled to limit the nitrogen load to the posttreatment.

The UASB-digester effluent does not yet meet discharge standards and requires post treatment to remove residual COD, dissolved methane and nutrients (like nitrogen). Further studies on this system should also focus on a more detailed effluent characterisation. Autotrophic nitrogen removal using Anammox bacteria presents a promising option, as it does not require organic carbon and allows for maximum COD removal and energy recovery in the UASB-digester (Hendrickx et al., 2012). An alternative could be denitrification with dissolved methane (Kampman et al., 2012), which removes both nitrogen and the greenhouse gas methane.

The excess sludge production in the UASB-digester with co-digestion was low with $0.212 \mathrm{~g} \mathrm{TSS} / \mathrm{g} \mathrm{COD}_{\text {removed, }}$ calculated from the results in the stable phase of period 3. This value is similar to the result reported by Mahmoud (2004). The biogas produced by the UASB-digester can be used to generate heat and electricity (e.g. in a combined heat and power unit). The electricity can be used for the aeration in the post-treatment processes. The heat can be locally used for warming up the sludge transferred from the UASB reactor $\left(15^{\circ} \mathrm{C}\right)$ to the digester $\left(35^{\circ} \mathrm{C}\right)$.

\subsection{Conclusions}

Co-digestion enables wider application of the UASB-digester for low temperature municipal sewage anaerobic treatment. Using glucose as a model co-substrate, we achieved:

- Clear increase in soluble sewage COD removal efficiency from 6.1 to $23.0 \%$, which was similar to its BMP of 17-32\%

- SMA of the UASB and the digester sludge at $15^{\circ} \mathrm{C}$ tripled to reach 43 and $39 \mathrm{mg}$ $\mathrm{CH}_{4}-\mathrm{COD} /(\mathrm{g}$ VSS $\cdot \mathrm{d}$ ) respectively

- Methane production in the UASB reactor increased by more than $90 \%$ because of its doubled methanogenic capacity 
- Capture and subsequent methanisation of suspended sewage COD also improved

\section{Acknowledgements}

The authors thank Jose Luis Ruiz for performing part of the presented results. The Technology Foundation STW (STW project 07736), the Netherlands, supported Tim Hendrickx and Christel Kampman. 


\section{Anaerobic treatment of domestic wastewater in a UASB-digester demonstrated at a temperature of $10^{\circ} \mathrm{C}$}

Lei Zhang, Jo De Vrieze, Tim L.G. Hendrickx, Wei Wei, Hardy Temmink, Huub Rijnaarts, Grietje Zeeman

This chapter is to be submitted 


\begin{abstract}
Direct anaerobic treatment of domestic wastewater is becoming attractive as it can change a wastewater treatment plant from energy consuming to energy producing. A pilot scale UASB-digester was studied to treat domestic wastewater at temperatures of $10-20^{\circ} \mathrm{C}$ and an HRT of $6 \mathrm{~h}$. The results show a stable chemical oxygen demand (COD) removal efficiency of $60 \pm 4.6 \%$ during the operation at 12.5 to $20^{\circ} \mathrm{C}$. COD removal efficiency decreased to $51.5 \pm 5.5 \%$ at $10^{\circ} \mathrm{C}$. The decreased COD removal efficiency was attributed to an increased influent COD load, leading to insufficient methanogenic

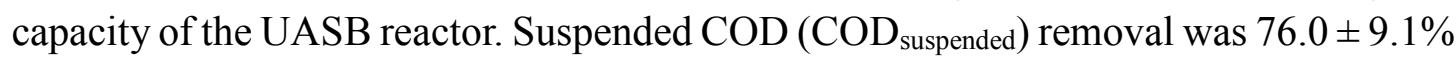
at $10-20^{\circ} \mathrm{C}$. Soluble $\mathrm{COD}$ removal $\left(\mathrm{COD}_{\text {soluble }}\right)$ fluctuated due to variation of the influent COD concentration, but the effluent COD concentration remained $90 \pm 23$ $\mathrm{mg} / \mathrm{L}$ at temperatures between 12.5 and $20^{\circ} \mathrm{C}$. The methane production $\left(\mathrm{COD}_{\mathrm{CH} 4}\right)$ was $39.7 \pm 4.4 \%$ of the influent COD, which was $80 \%$ of influent biological methane potential (BMP). Of the total methane yield, $49 \%$ was produced in the UASB reactor operated at a low temperature, and $51 \%$ in the digester. Discharged sludge accounted for $8 \pm 5 \%$ of the influent COD. The specific methanogenic activity (SMA) of the UASB sludge and the digester sludge was $0.26 \pm 0.03$ and $0.29 \pm 0.03 \mathrm{~g} \mathrm{CH}_{4} \mathrm{COD} /(\mathrm{g}$ VSS d), respectively. The stability of the UASB sludge and the digester sludge, was $0.25 \pm 0.02$ and $0.20 \pm 0.02 \mathrm{~g} \mathrm{CH}_{4} \mathrm{COD} / \mathrm{g} \mathrm{COD}$. The methanogenic community analysis revealed an overall dominance of the acetoclastic Methanosaetaceae and the hydrogenotrophic Methanomicrobiales during the operation between $10-20^{\circ} \mathrm{C}$.
\end{abstract}




\subsection{Introduction}

Anaerobic treatment of domestic wastewater saves energy, generates energy in the form of methane, and only produces a small amount of excess sludge. These advantages of anaerobic treatment result in a reduction of the operational costs compared with conventional domestic wastewater treatment (Speece, 2008). Besides, autotrophic nitrogen removal processes such as anaerobic ammonium oxidation (Anammox) and denitrification coupled to anaerobic methane oxidation (DAMO) are being developed for mainstream nitrogen and methane removal after anaerobic treatment (Hendrickx et al., 2012; Kampman et al., 2012). Latter processes are attractive for combination with anaerobic treatment as organic carbon is not required. This would make it feasible to transform net energy consuming domestic wastewater treatment plants into net energy producing plants.

Anaerobic treatment of domestic wastewater already is applied in tropical countries like Brazil and India, where the temperature of domestic wastewater favors mesophilic anaerobic bacteria (Seghezzo et al., 1998). Lower temperature $\left(<20^{\circ} \mathrm{C}\right)$ anaerobic wastewater treatment however still presents a challenge, mainly because of a low hydrolysis rate of organic solids and low methanogenic growth rates (Lettinga et al., 2001).

Different types of anaerobic reactors have been studied for low temperature wastewater treatment, including expanded granular sludge bed (EGSB) reactors, combinations of an EGSB with an anaerobic filter (AF), up-flow anaerobic sludge blanket (UASB) reactors, anaerobic baffled reactors (ABR), anaerobic migrating blanket reactor (AMBR) and anaerobic membrane bioreactors (Angenent et al., 2001; Ho \& Sung, 2009; Langenhoff \& Stuckey, 2000; McKeown et al., 2009b; Rebac et al., 1999c; Uemura \& Harada, 2000). Generally, these reactors achieved a good chemical oxygen demand (COD) removal efficiency of $70 \%$ to $90 \%$ at temperatures between 4 and $25^{\circ} \mathrm{C}$ and for wastewaters that mainly consisted of soluble $\mathrm{COD}\left(\mathrm{COD}_{\text {soluble }}\right)$. However, domestic wastewaters contain a high fraction of suspended COD ( $\left.\mathrm{COD}_{\text {suspended }}\right)$, typically $55 \%$ (Mahmoud et al., 2004). Because of limited hydrolysis of this $\mathrm{COD}_{\text {suspended }}$ at low temperatures it would result in $\mathrm{COD}_{\text {suspended }}$ accumulation in the reactor, unlike a very long hydraulic retention time (HRT) is being applied. An upflow anaerobic solids

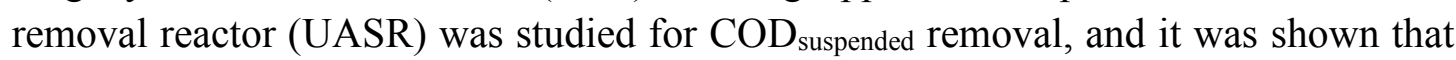
$65 \%$ of the $\mathrm{COD}_{\text {suspended }}$ could be entrapped in the sludge bed when treating domestic wastewater at $17^{\circ} \mathrm{C}$ and at an HRT of $3 \mathrm{~h}$ (Zeeman et al., 1997). Hydrolysis of $\mathrm{COD}_{\text {suspended }}$ was shown to be limited, viz. only $0.7 \%$. A two-step AF +_anaerobic hybrid $(\mathrm{AH})$ reactor was studied for treatment of domestic wastewater at $13^{\circ} \mathrm{C}$. The $\mathrm{AH}$ reactor consisted of a granular sludge bed with vertical sheets of reticulated polyurethane foam (RPF) with knobs. The RPF was used for entrapment of solids. This $\mathrm{AF}+\mathrm{AH}$ system achieved a $\mathrm{COD}_{\text {suspended }}$ removal efficiency of $81 \%$ and a total COD $\left(\mathrm{COD}_{\mathrm{t}}\right)$ removal efficiency of $71 \%$ at HRTs of $4 \mathrm{~h}(\mathrm{AF})$ and $8(\mathrm{AH}) \mathrm{h}$ (Elmitwalli et al., 2002a; Elmitwalli et al., 2002b). However, the excess sludge that is produced by 
entrapment of influent $\mathrm{COD}_{\text {suspended }}$ in these systems still needs further treatment.

Mahmoud et al. (2004) investigated a UASB-digester system for low temperature domestic wastewater treatment. This system treats wastewater in a UASB reactor at a short HRT. The UASB sludge is recirculated over a heated digester where the wastewater $\mathrm{COD}_{\text {suspended, }}$ captured in the UASB reactor, is converted to methane. The stabilized digester sludge is returned to the UASB reactor where it continues to capture wastewater organic solids and at the same time supplies methanogenic biomass to the UASB reactor for conversion of the $\mathrm{COD}_{\text {soluble }}$ in the wastewater. To improve the performance of the UASB-digester system the effect of the sludge recirculation rate between the UASB reactor and the digester and the addition of external co-substrates to the digester were investigated. It was shown that the biogas production of the digester increased from 2.9 to $7.4 \mathrm{~L} / \mathrm{d}$, and stability of the UASB sludge was improved from 0.37 to $0.15 \mathrm{~g} \mathrm{CH}_{4} \mathrm{COD} / \mathrm{g}$ sludge COD by increasing the sludge recirculation ratio from 0.9 to $2.6 \%$ of the wastewater flow rate (Zhang et al., 2012). Further increasing this ratio to $12.5 \%$ did not have a significant effect. Co-digestion increases the number of methanogens in the digester and herewith the methanogenic capacity and $\mathrm{COD}_{\text {soluble }}$ removal in the UASB reactor (Zhang et al., 2013). Glucose as a model substrate was added at an amount of $14 \%$ of influent organic loading, and $\mathrm{COD}_{\text {soluble removal }}$ increased from 6 to $23 \%$, and SMA of the UASB and digester sludge tripled to 43 and $39 \mathrm{mg} \mathrm{CH}{ }_{4} \mathrm{COD} /(\mathrm{g} \mathrm{VSS} \mathrm{d})$ at $15^{\circ} \mathrm{C}$ respectively. Therefore, adding co-substrate may be an attractive alternative, especially at very low temperatures and if the $\mathrm{COD}_{\text {suspended }}$ to $\mathrm{COD}_{\text {soluble }}$ ratio of the domestic wastewater is low.

Thus, the UASB-digester system was only studied for domestic wastewater treatment at $\geq 15^{\circ} \mathrm{C}$. At this temperature a COD removal of 66 and 52\% was achieved at an HRT of $6 \mathrm{~h}$ in the UASB reactor as reported by Mahmoud et al. (2004) and by Álvarez et al. (2004), respectively. However, the temperature of domestic wastewater in moderate climate zones can be as low as $10^{\circ} \mathrm{C}$ and therefore the feasibility of the UASB-digester also needs to be assessed at temperatures below $15^{\circ} \mathrm{C}$. For this purpose, a pilot-scale UASB-digester was operated, of which the UASB initially was operated at $20^{\circ} \mathrm{C}$. The temperature was subsequently decreased in steps to $10^{\circ} \mathrm{C}$ and removal efficiency for total COD $\left(\mathrm{COD}_{\mathrm{t}}\right)$ and of its fractions (suspended, soluble and colloidal), methane production of the UASB reactor and the digester and the COD balance were determined. In addition, the microbial community in the UASB and digester were assessed to provide insight in the effect of temperature on this community and its relation to process performance.

\subsection{Materials and method}

\subsubsection{Experiment set-up}

Screened wastewater $(<3 \mathrm{~mm})$ originated from the domestic wastewater treatment plant in Bennekom, the Netherlands. The wastewater was transported to the pilot-scale 


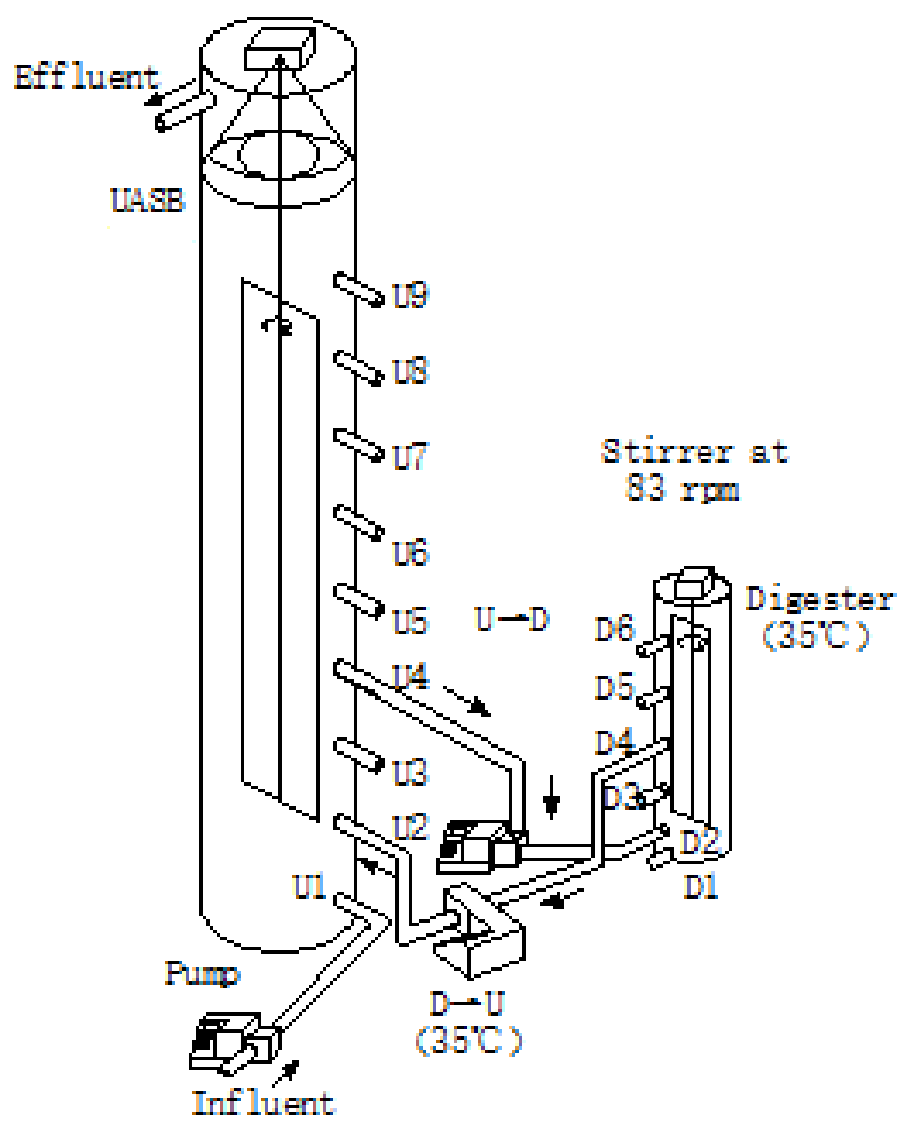

Fig.4.1 A pilot scale UASB-digester used in the study (the UASB reactor was operated at $10-20^{\circ} \mathrm{C}$; the digester was operated at $35^{\circ} \mathrm{C}$ )

UASB-digester. A stirred tank (Mueller, the Netherlands) with a volume of $4 \mathrm{~m}^{3}$ was used as a buffer to collect (twice per week) and store the sewage before feeding it to the UASB-digester. The temperature of the tank was $4^{\circ} \mathrm{C}$ to minimize biological conversion processes.

The wastewater passed a double walled metal column (height: $65 \mathrm{~cm}$, diameter of the outside layer and inside layer: 51 and $40 \mathrm{~cm}$ ). Water at a temperature of $10-20^{\circ} \mathrm{C}$ provided by a cooler (Julabo FC 1200, Germany) was applied in countercurrent with the wastewater. The water subsequently was guided through a rubber tube surrounding the UASB reactor. Water provided by a water bath (Julabo, Germany) was applied to heat the double walled digester to keep the reactor at $35^{\circ} \mathrm{C}$. The UASB reactor and digester were insulated using foam sheets and aluminum.

Along the height of the UASB reactor and digester 9 (distance of $30 \mathrm{~cm}$ between them) and 6 (distance of $18 \mathrm{~cm}$ between them) sludge sampling and discharge ports were installed (Fig.4.1), respectively. The sludge was recirculated from the UASB sludge port 4 (U4) to the digester sludge port 1 (D1) and recirculated to the UASB reactor from port D4 to port U2. Each two hours the UASB sludge bed was stirred for two minutes at $1 \mathrm{rpm}$ to avoid short circuiting and dead zones. The digester worked as a continuous 
Table 4.1 Operational and design parameters of the UASB-digester system

\begin{tabular}{ccc}
\hline Parameter & UASB & Digester \\
Temperature $\left({ }^{\circ} \mathrm{C}\right)$ & $10-20$ & 35 \\
Diameter $(\mathrm{cm})$ & 23.5 & 23.5 \\
Liquid height (m) & 3 & 1 \\
Working volume (L) & 130 & 43 \\
Up - flow velocity (m/h) & 0.5 & - \\
HRT (d) & 0.25 & 0.5 \\
\hline Mixing intensity (rpm) & 0.02 & 83 \\
\hline
\end{tabular}

stirred tank reactor (CSTR), and mechanical mixing was applied at $83 \mathrm{rpm}$. Weekly 10$15 \mathrm{~L}$ of excess sludge was wasted from the UASB reactor from U8 and 0-5 L from the digester from D5.

The design and the operational parameters of the pilot-scale UASB-digester are shown in Table 4.1. The inoculum that was used to start-up the system was 1-year stored sludge from a similar UASB-digester system (Zhang et al., 2013). The UASB-digester in this study had already been operated for a period of 2 years on domestic sewage with a COD concentration of $627 \pm 213 \mathrm{mg} / \mathrm{L}$ and a temperature of $10-20^{\circ} \mathrm{C}$ before starting the here presented experiments. A high sludge recirculation rate of $16 \%$ of the wastewater flow rate was applied to enable full transfer of fresh influent $\mathrm{COD}_{\text {suspended }}$ to the digester. To confirm that a sufficiently high recirculation rate was applied, the stability of the UASB sludge was determined in batch experiments (see later). The wastewater temperature was decreased in steps of $2.5^{\circ} \mathrm{C}$ from 20 to $10^{\circ} \mathrm{C}$. Each step lasted for a minimum of 6 weeks, provided that the fluctuation in $\mathrm{COD}_{\mathrm{t}}$ removal was less than $10 \%$. The periods of each temperature operation were: 0-46, 47-94, 95-142, 143-212, 213-262 and 263287 days for $20,17.5,15,12.5,10$ and $11-13^{\circ} \mathrm{C}$ respectively.

\subsubsection{Batch experiments}

\subsubsection{Specific methanogenic activity (SMA) and stability of the sludge}

The SMA refers to the maximum rate of methane production per gram of volatile suspended solids (VSS). The stability of sludge presents the fraction of biodegradable 
COD that still is present in the sludge and that can be converted into methane. The SMA and stability tests were performed according to the method reported by Zhang et al. (2013). Approximately $30 \mathrm{~mL}$ sludge samples were collected from each sludge port of the UASB reactor and mixed for the SMA tests at $10,15,25$, and $35^{\circ} \mathrm{C}$ and for stability tests. The digester sludge samples of about $200 \mathrm{ml}$ were collected from port D5.

\subsubsection{Biological methane potential (BMP) of domestic wastewater}

The BMP is the maximum amount of methane, expressed as $\mathrm{g} \mathrm{CH}_{4} \mathrm{COD} / \mathrm{g} \mathrm{COD}$, that can be produced from a substrate. The BMP of domestic wastewater was determined at $35^{\circ} \mathrm{C}$ according to a procedure described by Zhang et al. 2013. Different fractions of the domestic wastewater, viz. raw, paper filtered and membrane filtered domestic wastewater were tested for 30 days because after these 30 days no further methane production was observed. BMP of the influent $\mathrm{COD}_{\text {total }}, \mathrm{COD}_{\text {suspended }}$ and $\mathrm{COD}_{\text {soluble }}$ was calculated. The average BMP in the whole study period was used to calculate the biodegradable fraction of influent OLR.

\subsubsection{Dissolved methane in the effluent}

Dissolved methane concentrations in effluent samples were determined in triplicate by gas chromatography (GC) analyses according to the method described by Zhang et al. (2013).

\subsubsection{Microbial community analysis}

The samples for microbial community analysis were taken from the influent, the effluent, the mixed sludge from U1-U9 of the UASB reactor, the digester and U4.

$45 \mathrm{ml}$ of each sample was collected on $31 \mathrm{~d}, 88 \mathrm{~d}, 117 \mathrm{~d}, 166 \mathrm{~d}$ and $249 \mathrm{~d}$ for 20, 17.5, $15,12.5$ and $10^{\circ} \mathrm{C}$, respectively. Total DNA was extracted from sludge samples that were stored at $-20^{\circ} \mathrm{C}$, according to (Vilchez-Vargas et al., 2013). A conventional PCR, targeting total bacteria, was performed prior to real-time PCR analysis according to (Boon et al., 2002), using the total bacterial primers P338f and P518r (Muyzer et al., 1993), to verify if no components were present in the DNA extracts that could inhibit PCR. The quality of DNA extracts and PCR products were validated by agarose gel electrophoresis. Real-time PCR analysis was carried out using a StepOnePlus ${ }^{\mathrm{TM}}$ RealTime PCR System (Applied Biosystems, Carlsbad, CA). The methanogens Methanobacteriales, Methanomicrobiales, Methanosarcinaceae, and Methanosaetaceae, as well as total Bacteria were analyzed, as described earlier by Desloover et al. (2015). Each sample was analyzed in triplicate. Real-time PCR quality was evaluated through the different parameters obtained with the StepOnePlus software V2.3 (Table 1, Annex 1). Results were presented as copies per gram of wet sludge.

\subsubsection{Analytical methods}

The frequency of the measurements in this study is shown in Table 4.2. $\mathrm{COD}_{\mathrm{t}}$, 
Table 4.2 Frequency of measurements

\begin{tabular}{|c|c|c|c|c|c|c|c|c|}
\hline & $\mathrm{pH}$ & $\begin{array}{c}\text { COD } \\
\text { concentration }\end{array}$ & $\begin{array}{l}\text { Biogas } \\
\text { production rate } \\
\text { of the UASB- } \\
\text { digester }\end{array}$ & $\begin{array}{l}\text { Methane } \\
\text { composition of } \\
\text { the UASB- } \\
\text { digester }\end{array}$ & $\begin{array}{l}\text { Dissolved } \\
\text { methane }\end{array}$ & $\begin{array}{c}\text { Stability and SMA } \\
\text { of the UASB- } \\
\text { digester sludge }\end{array}$ & $\begin{array}{l}\text { TSS/VSS of the } \\
\text { UASB-digester } \\
\text { sludge }\end{array}$ & $\begin{array}{l}\text { BMP of } \\
\text { influent }\end{array}$ \\
\hline Frequency & $\begin{array}{l}\text { 1-2 times/ } \\
\text { week }\end{array}$ & $\begin{array}{l}\text { 1-2 times/ } \\
\text { week }\end{array}$ & Daily & 1 time / week & $\begin{array}{l}1 \text { time / } \\
\text { week }\end{array}$ & 1 time/ 2 weeks & $\begin{array}{l}1 \text { time } \\
\text { /2 weeks }\end{array}$ & $\begin{array}{l}\text { 1-2 times } \\
\text { / month }\end{array}$ \\
\hline
\end{tabular}

Table 4.3 COD concentration, OLR and BMP of domestic wastewater ( - : not available)

\begin{tabular}{|c|c|c|c|c|c|c|c|c|c|c|c|c|c|}
\hline \multirow{2}{*}{$\begin{array}{c}\text { Temperature } \\
\left({ }^{\circ} \mathrm{C}\right)\end{array}$} & \multirow{2}{*}{$\mathrm{pH}$} & \multicolumn{4}{|c|}{ COD concentration $(\mathrm{mg} / \mathrm{L})$} & \multicolumn{4}{|c|}{$\operatorname{OLR}(\mathrm{g} \mathrm{COD} /(\mathrm{L} \mathrm{d}))$} & \multicolumn{4}{|c|}{$\mathrm{BMP}\left(\mathrm{g} \mathrm{CH}_{4} \mathrm{COD} / \mathrm{g} \mathrm{COD}\right)$} \\
\hline & & total & suspended & soluble & colloidal & total & suspended & soluble & colloidal & total & suspended & soluble & colloidal \\
\hline $10-20$ & $\begin{array}{l}7.1- \\
7.8\end{array}$ & $\begin{array}{c}630 \\
(190)\end{array}$ & $\begin{array}{c}342 \\
(131)\end{array}$ & $\begin{array}{l}167 \\
(72)\end{array}$ & $\begin{array}{l}151 \\
(42)\end{array}$ & $\begin{array}{c}2.5 \\
(0.8)\end{array}$ & $\begin{array}{c}1.4 \\
(0.5)\end{array}$ & $\begin{array}{l}0.67 \\
(0.3)\end{array}$ & $\begin{array}{l}0.61 \\
(0.2)\end{array}$ & $\begin{array}{c}0.51 \\
(0.08)\end{array}$ & $\begin{array}{c}0.55 \\
(0.10)\end{array}$ & $\begin{array}{c}0.40 \\
(0.12)\end{array}$ & - \\
\hline
\end{tabular}


$\mathrm{COD}_{\text {suspended }}, \mathrm{COD}_{\text {colloidal }}, \mathrm{COD}_{\text {soluble, }}$ UASB sludge $\mathrm{COD}$, digester sludge COD and discharged sludge COD were measured by cuvette tests (Hach Lange, USA). Domestic wastewater, sampled after passing the influent pump, was analyzed for $\mathrm{COD}_{t}$, distinguishing between $8 \mu \mathrm{m}$ paper-filtered (Whatman grade 40, Germany) particulate sewage $\mathrm{COD}\left(\mathrm{COD}_{\mathrm{p}}\right)$ and $0.45 \mu \mathrm{m}$ membrane-filtered (Whatman FP 30/ 0.45 CA, Germany) $\mathrm{COD}_{\text {soluble. }} \mathrm{COD}_{\text {suspended }}$ and $\mathrm{COD}_{\text {colloidal }}$ were calculated according to $\mathrm{COD}_{\text {suspended }}=\mathrm{COD}_{\mathrm{t}}-\mathrm{COD}_{\mathrm{p}}$ and $\mathrm{COD}_{\text {colloidal }}=\mathrm{COD}_{\mathrm{p}}-\mathrm{COD}_{\text {soluble, }}$, respectively. $\mathrm{A}$ mixture of UASB sludge from the ports U1 to U9 was sampled for COD measurement.

Volatile suspended solids (VSS) and total suspended solids (TSS) were measured using standard methods given by American Public Health Association (APHA, 2005). PH was measured using a $\mathrm{pH}$ meter (PHM210, Radiometer analytical sas, France). Biogas production was measured by a wet gas meter (Ritter, Germany). Concentrations of nitrogen, methane, and carbon dioxide in the headspaces of the batch experiments and in the biogas produced by the UASB-digester were measured using a gas chromatograph (GC) (Interscience GC 8000 series) (Zhang et al. 2013).

$900 \mu \mathrm{L}$ of influent/effluent sample, filtered by $0.45 \mu \mathrm{m}$ membrane filter, was mixed with $100 \mu \mathrm{L}$ of $15 \%$ formic acid to prepare VFA samples $(1.5 \%$ formic acid in the measured sample). GC (HP $5890 \mathrm{GC}$ ) was used to determine the VFA concentrations (Zhang et al. 2013).

\subsubsection{Calculation}

\subsubsection{Solids retention time (SRT)}

The SRT of the UASB digester system was calculated based on VSS concentrations and the number of solids that was wasted from the UASB and from the digester. This will be referred to as the maximum SRT ( $\mathrm{SRT}_{\max }$ ). The minimum SRT ( $\mathrm{SRT}_{\min }$ ) was calculated in a similar way but included wash-out of VSS with the effluent from the UASB. Effluent VSS concentrations were measured during operation of the UASB reactor at $20^{\circ} \mathrm{C}$, and were found to be half of the effluent $\mathrm{COD}_{\text {suspended }}$ concentration in this effluent (Table 2, Annex 2). No VSS concentrations are determined for the UASB effluent during operation at the other temperatures. Therewith, we took this ratio to calculate the $\mathrm{SRT}_{\text {min. }}$.

\subsubsection{Methanogenic capacity}

The methanogenic capacity of a reactor is defined as its maximum methane production ability in $\mathrm{g} \mathrm{CH}_{4} \mathrm{COD} / \mathrm{d}$, and was calculated by multiplying the SMA of the sludge with the total amount of VSS in the reactor. The methanogenic capacity was compared to the real methane production rate for both the UASB reactor and digester.

\subsubsection{COD mass balance}

For each period of a constant UASB temperature, the amount of COD that was fed to the UASB-digester system was compared with the cumulative distribution of COD to: 1) Methane, 2) Discharged sludge, 3) Effluent and 4) COD that accumulated in the 
reactors and that was calculated as the difference between the sludge COD in the UASB-digester between the start and the end of each period.

\subsubsection{Hydrolysis of influent organic solids in the UASB reactor}

For each temperature, the hydrolysis yield of the influent $\mathrm{COD}_{\text {suspended }}$ of the domestic wastewater in the UASB reactor was calculated according to:

Hydrolysis yield $=100 \times\left(\right.$ methane production rate $\left.\mathrm{UASB}_{-}-\mathrm{COD}_{\text {soluble removal rate }}\right) / \mathrm{L}_{\mathrm{CODssbiod}}$

With hydrolysis yield the fraction of organic solids of the domestic wastewater hydrolysed in the UASB reactor $(\%)$, methane production rate UASB the average methane production rate of the UASB reactor $\left(\mathrm{g} \mathrm{CH}_{4} \mathrm{COD} / \mathrm{d}\right), \mathrm{COD}_{\text {soluble removal rate, the average }}$ $\mathrm{COD}_{\text {soluble removal rate, }}(\mathrm{g} \mathrm{COD} / \mathrm{d})$ and $\mathrm{L}_{\text {coDssbiod }}$ the average loading rate of biodegradable suspended COD (g COD/d).

\subsection{Results}

\subsubsection{COD removal}

The UASB-digester system achieved a stable COD removal efficiency (Fig.4.2a) in spite of a decreasing temperature from 20 to $12.5^{\circ} \mathrm{C}$. The temperature did not have a significant effect on average COD removal efficiency at $12.5-20^{\circ} \mathrm{C}$ at $\mathrm{P}=0.05$ level, and the overall average COD removal efficiency was $60.0 \pm 4.6 \%$ at $12.5-20^{\circ} \mathrm{C}$. The mean effluent COD concentration was $242 \pm 49 \mathrm{mg} / \mathrm{L}$ at an influent COD concentration of $616 \pm 140 \mathrm{mg} / \mathrm{L}$. At $10^{\circ} \mathrm{C}$ the COD removal efficiency decreased to $51.5 \pm 5.5 \%$. This was accompanied by a significant increase of the influent COD concentration from 514 \pm 110 at $12.5^{\circ} \mathrm{C}$ to $764 \pm 124 \mathrm{mg} / \mathrm{L}$ at $10^{\circ} \mathrm{C}$. The temperature was subsequently increased from 10 to $11-13^{\circ} \mathrm{C}$, in an attempt to recover the performance. As a result, the average effluent COD decreased again to $237 \pm 43 \mathrm{mg} / \mathrm{L}$, similar to that achieved at $12.5-20^{\circ} \mathrm{C}$.

The results in Fig.4.2b show that the average $\mathrm{COD}_{\text {suspended }}$ removal efficiencies at temperatures between 10 and $20^{\circ} \mathrm{C}$ were not significantly different at $\mathrm{P}=0.05$ level, with an overall efficiency of $76.0 \pm 9.1 \%$. The average effluent $\mathrm{COD}_{\text {suspended }}$ concentration at temperatures of 12.5 to $20^{\circ} \mathrm{C}$ was $67 \pm 28 \mathrm{mg} / \mathrm{L}$ at an average influent $\mathrm{COD}_{\text {suspended }}$ concentration of $306 \pm 111 \mathrm{mg} / \mathrm{L}$. The effluent $\mathrm{COD}_{\text {suspended }}$ concentration increased to $100 \pm 23 \mathrm{mg} / \mathrm{L}$ as the temperature decreased from 12.5 to $10^{\circ} \mathrm{C}$. This increase was probably due to the significant increase of the influent $\mathrm{COD}_{\text {suspended }}$ concentration from $208 \pm 43$ to $463 \pm 114 \mathrm{mg} / \mathrm{L}$ in this period. The high influent COD concentration in this period was therefore mainly due to the increase of the $\mathrm{COD}_{\text {suspended }}$ concentration. During the last period, operating the UASB at temperatures of $11-13^{\circ} \mathrm{C}$, the average effluent $\mathrm{COD}_{\text {suspended }}$ concentration decreased to $56 \pm 11 \mathrm{mg} / \mathrm{L}$, similar to that achieved before at $12.5-20^{\circ} \mathrm{C}$. 

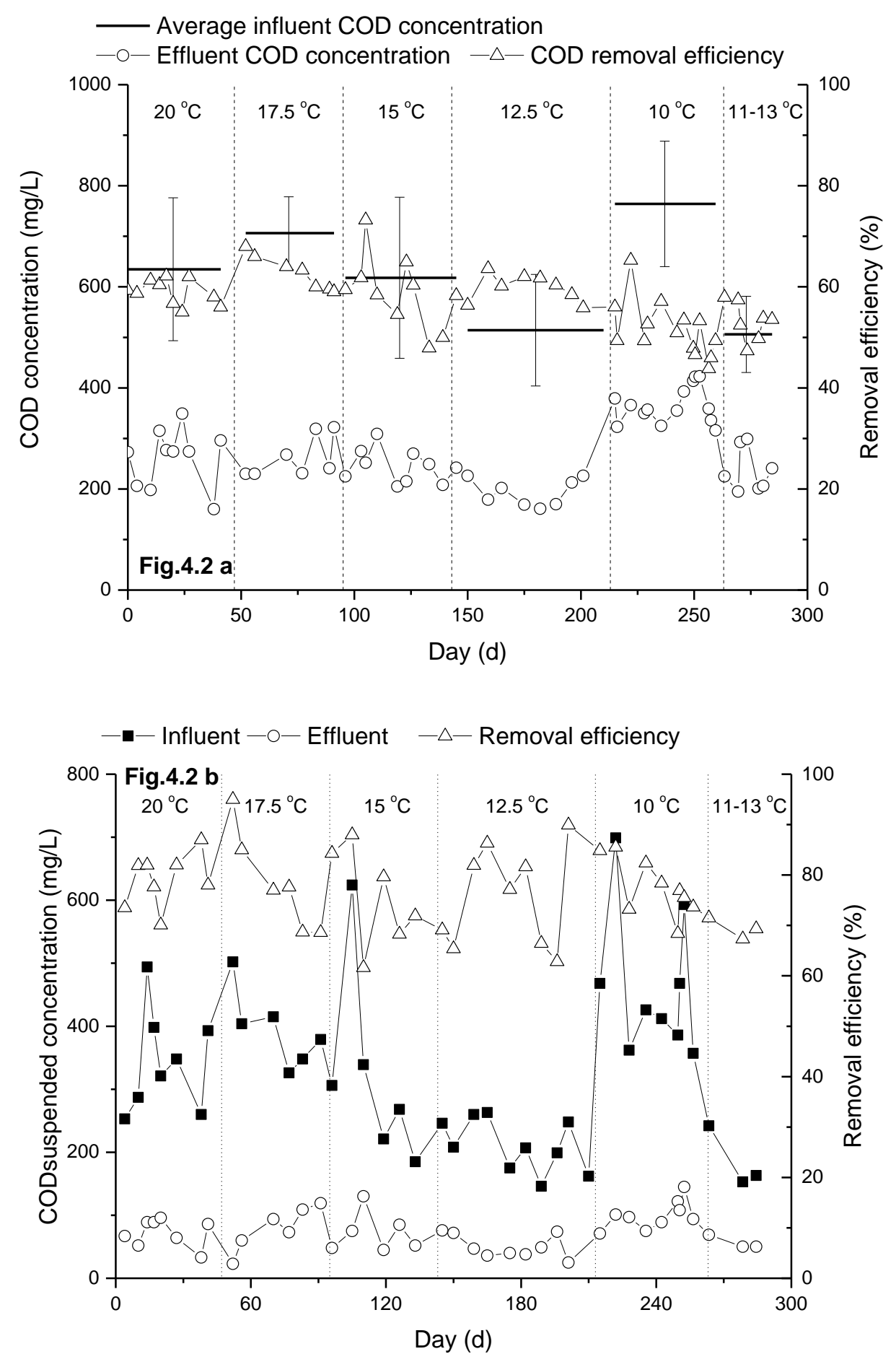

Fig.4.2 COD removal efficiency of the UASB-digester treating municipal wastewater at $10-20^{\circ} \mathrm{C}$ (a: total COD removal; b: suspended COD removal) 

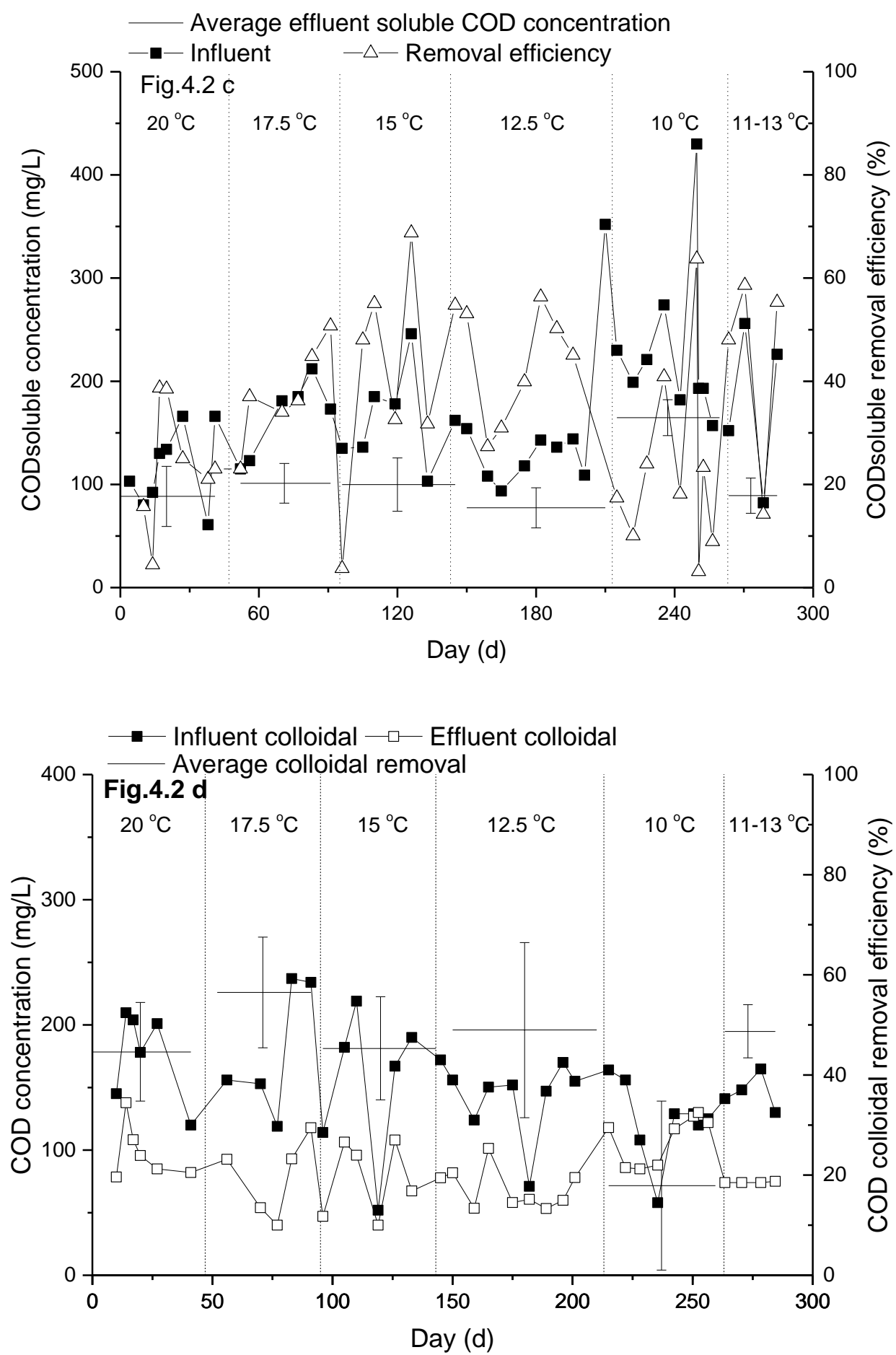

Fig.4.2 COD removal efficiency of the UASB-digester treating municipal wastewater at $10-20^{\circ} \mathrm{C}$ (c: soluble COD removal; d: colloidal COD removal)

$\mathrm{COD}_{\text {soluble }}$ removal is shown in Fig.4.2c. The average effluent $\mathrm{COD}_{\text {soluble }}$ concentration did not significantly change during the period when the temperature was decreased from 20 to $12.5^{\circ} \mathrm{C}$ at $\mathrm{P}=0.05$ level, and it was $91 \pm 25 \mathrm{mg} / \mathrm{L}$. No VFA could be detected in the effluent (data not shown). The $\mathrm{COD}_{\text {soluble }}$ decreased was close to the BMP of the influent $\mathrm{COD}_{\text {soluble }}\left(\right.$ Table 4.3 ). At $10^{\circ} \mathrm{C}$, the average effluent $\mathrm{COD}_{\text {soluble }}$ increased to 165 $\pm 17 \mathrm{mg} / \mathrm{L}$ and VFA was detected at a concentration of $36.2 \pm 7.9 \mathrm{mg} \mathrm{COD} / \mathrm{L}$ (about $5 \%$ 
of the influent COD as shown in Fig.4.5). The latter indicated that the methanogenic capacity of the UASB reactor was insufficient to deal with the increased loading rate. After the temperature was increased to $11-13^{\circ} \mathrm{C}$, and the influent COD concentration decreased during the same period, the $\mathrm{COD}_{\text {soluble }}$ removal efficiency increased to 44.0 $\pm 20.4 \%$ with an average effluent $\mathrm{COD}_{\text {soluble }}$ concentration of $89 \pm 17 \mathrm{mg} / \mathrm{L}$. VFA was no longer detected.

The average $\mathrm{COD}_{\text {colloidal }}$ removal efficiency was relatively stable at $12.5-20^{\circ} \mathrm{C}$ (at $\mathrm{P}=0.05$ level): $42.8 \pm 17.5 \%$ (Fig.4.2d). The average $\mathrm{COD}_{\text {colloidal }}$ removal efficiency decreased to $17.9 \pm 16.9 \%$ at $10^{\circ} \mathrm{C}$. The influent $\mathrm{COD}_{\text {colloidal }}$ concentration of $124 \pm 32$ $\mathrm{mg} / \mathrm{L}$ at $10^{\circ} \mathrm{C}$ was not significantly different from the one $(151 \pm 47 \mathrm{mg} / \mathrm{L})$ in the whole study period.

\subsubsection{Methane production rate}

The methane production rate of the digester followed the biodegradable fraction of the influent $\mathrm{COD}_{\text {suspended }}$ rate during the whole operational period (Fig.4.3). The average methane production rate was not significantly different at $\mathrm{P}=0.05$ level during each period with different influent temperatures. The average methane production was $60 \pm$ $17 \mathrm{~g} \mathrm{CH}_{4} \mathrm{COD} / \mathrm{d}$, which was lower than the average influent loading rate of biodegradable $\mathrm{COD}_{\text {suspended }}$ of $90 \pm 36 \mathrm{~g} \mathrm{CH}_{4} \mathrm{COD} / \mathrm{d}$. The methane production rate of the digester was $67 \%$ of influent loading rate of biodegradable $\mathrm{COD}_{\text {suspended, which }}$ indicated that major part of the influent $\mathrm{COD}_{\text {suspended }}$ was biodegraded in the digester.

Fig.4 shows the average methane production rate of the UASB reactor at the different temperatures. Methane production included gaseous methane and effluent dissolved methane. The average measured gaseous methane production and load of effluent dissolved methane at $10-20^{\circ} \mathrm{C}$ were $22 \pm 10$ and $37 \pm 9 \mathrm{~g} \mathrm{CH}_{4} \mathrm{COD} / \mathrm{d}$, respectively. The measured load of effluent methane was in agreement with the one calculated with Henry's law using a methane fraction of $65.5 \pm 3.1 \%$ in the biogas of the UASB reactor.

The average removal rate of $\mathrm{COD}_{\text {soluble }}$ at $10-20^{\circ} \mathrm{C}$ was $26 \pm 6 \mathrm{~g} \mathrm{COD} / \mathrm{d}$ (Fig.4). The methane production of the UASB reactor was expected coming from the $\mathrm{COD}_{\text {soluble }}$ biodegradation. However, the $\mathrm{COD}_{\text {soluble }}$ removal rate was significantly lower than the average methane production rate of the UASB reactor of $59 \pm 10 \mathrm{~g} \mathrm{COD} / \mathrm{d}$. The difference can be attributed to the hydrolysis of influent organic solids in the UASB reactor, as will be discussed later. This is also in agreement with the results reported by Zhang et al. (2012) and Zhang et al. (2013), and can also explain the lower methane production rate in the digester in comparison with the loading rate of influent COD suspended (Fig.4.3). 


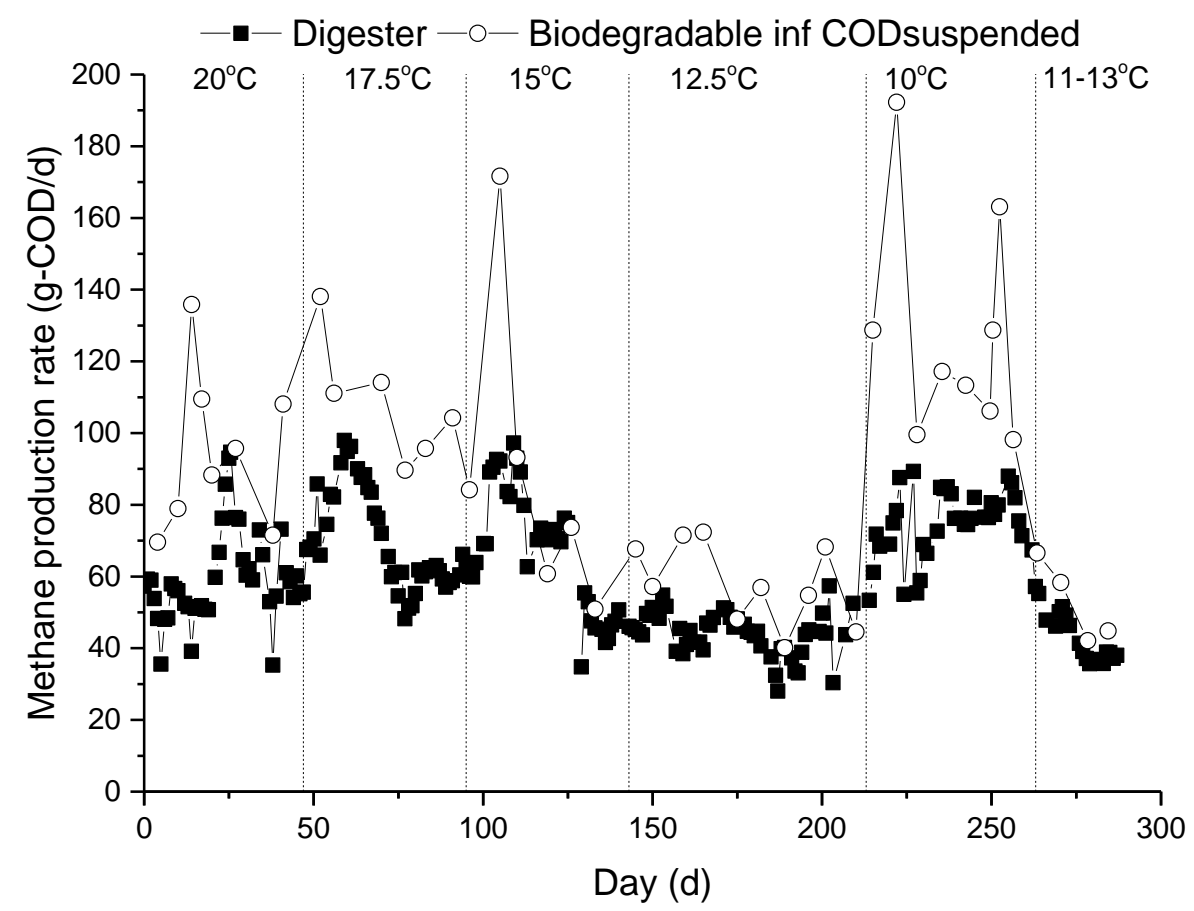

Fig.4.3 Methane production rate $\left(\mathrm{g} \mathrm{CH}_{4} \mathrm{COD} / \mathrm{d}\right)$ of the digester in the UASB-digester treating municipal wastewater at $10-20^{\circ} \mathrm{C}$

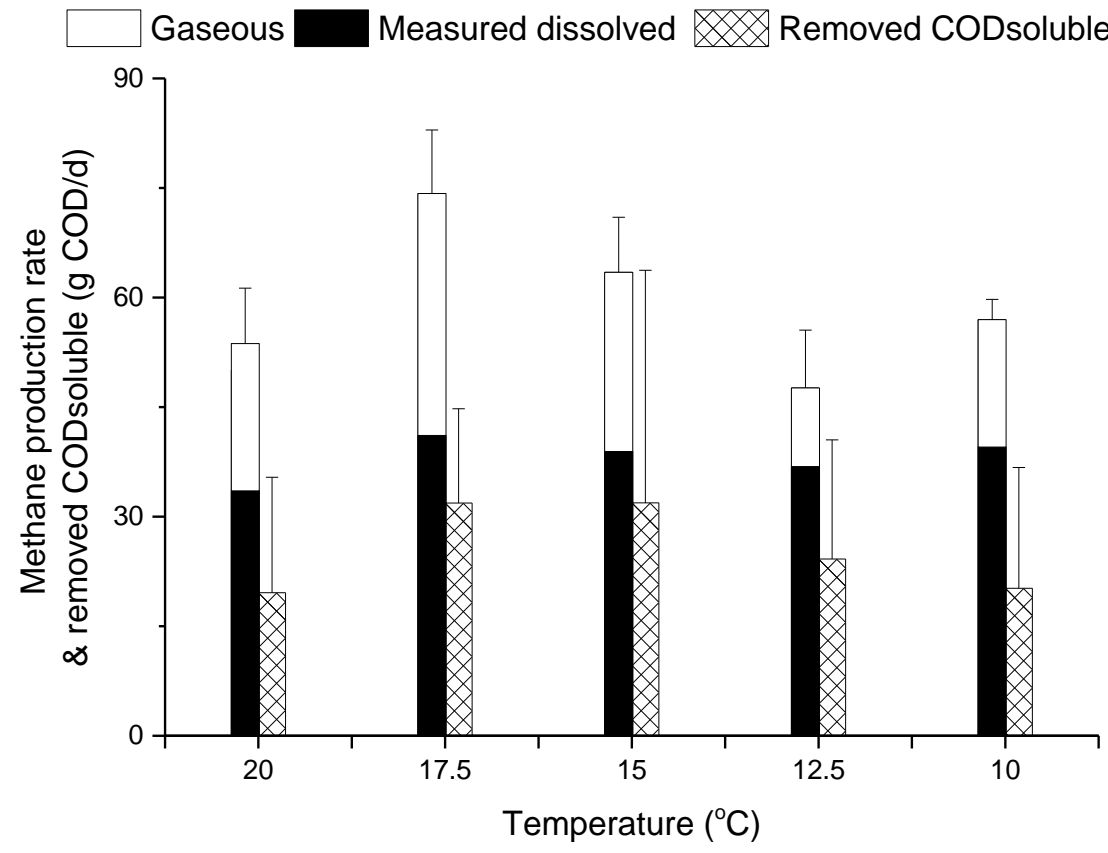

Fig.4.4 Methane production rate $\left(\mathrm{g} \mathrm{CH}_{4} \mathrm{COD} / \mathrm{d}\right)$ and removed $\mathrm{COD}_{\text {soluble }}$ rate of the UASB reactor in the UASB-digester treating municipal wastewater at $10-20^{\circ} \mathrm{C}$ 


\subsubsection{COD mass balance}

Fig.4.5 shows the (average) COD balance of the UASB-digester system at $12.5-20^{\circ} \mathrm{C}$ and at $10^{\circ} \mathrm{C}$. Methane production accounted for $40 \pm 4 \%$ at $10-20^{\circ} \mathrm{C}$. Given the influent BMP of $51 \pm 8 \%$ (Table 4.3), an average $80 \%$ of the influent BMP was converted to methane. Methane production in the UASB reactor contributed $49 \pm 5 \%$ to the total methane production. The gaseous methane and dissolved methane accounted for $18 \%$ and $31 \%$ of the total methane production, respectively. The average discharged sludge COD at $10-20^{\circ} \mathrm{C}$ accounted $8 \pm 5 \%$ of influent COD, which is low compared with traditional wastewater treatment. There was almost no COD $(<3 \%)$ accumulation at $10-20^{\circ} \mathrm{C}$.

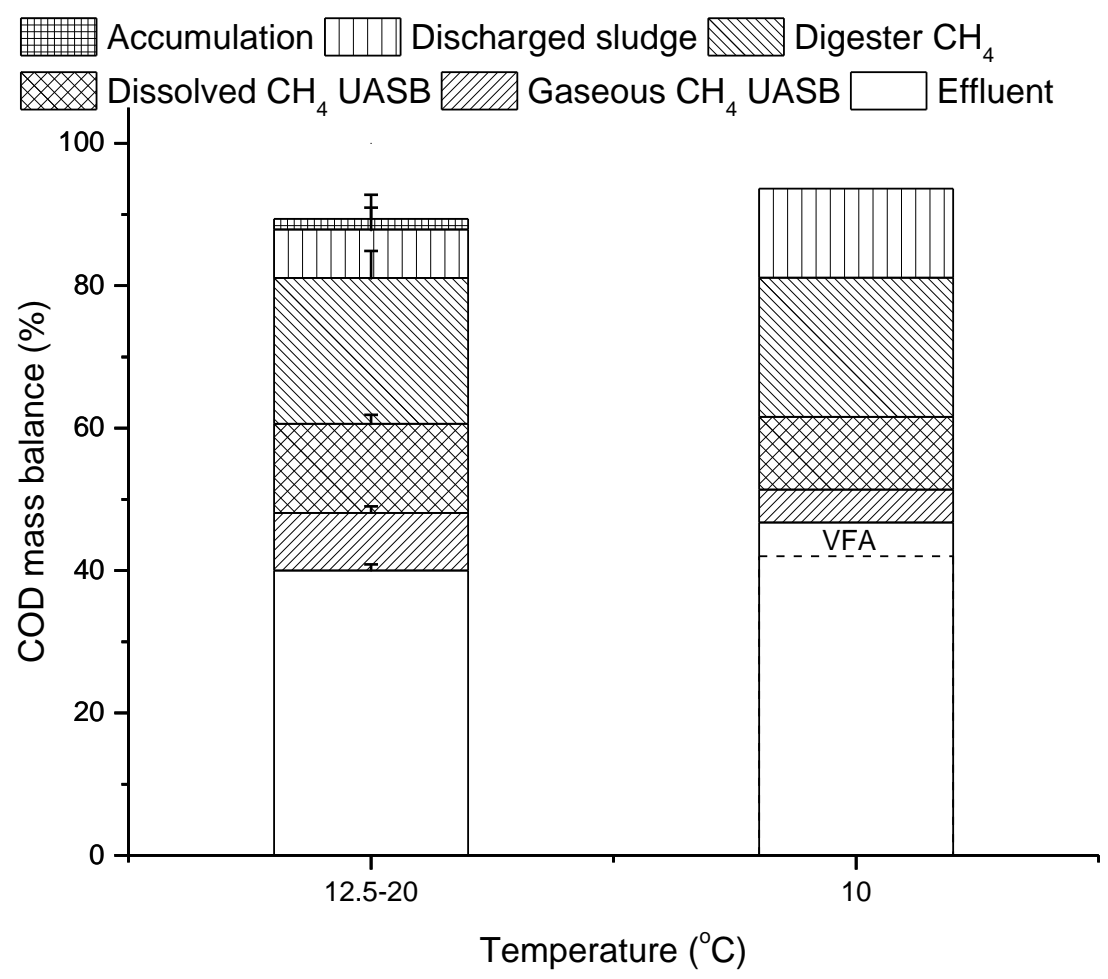

Fig.4.5 COD mass balance of the UASB-digester treating municipal wastewater at subsequently $12.5-20^{\circ} \mathrm{C}$ and $10^{\circ} \mathrm{C}$

\subsubsection{Methanogenic capacity}

SMA, stability, VSS and SRT of the UASB sludge and the digester sludge were relatively stable throughout the entire operational period (Table 4.4). The average methanogenic capacity of the UASB reactor at $35^{\circ} \mathrm{C}$ was $264 \pm 20 \mathrm{~g} \mathrm{CH}_{4} \mathrm{COD} / \mathrm{d}$. The methanogenic capacity of the UASB reactor decreased from $77 \pm 4 \mathrm{~g} \mathrm{CH}_{4} \mathrm{COD} / \mathrm{d}$ at $20^{\circ} \mathrm{C}$ to $31 \pm 4 \mathrm{~g} \mathrm{CH}_{4} \mathrm{COD} / \mathrm{d}$ at $10^{\circ} \mathrm{C}$. The methanogenic capacity of the UASB reactor was sufficient at $12.5-20^{\circ} \mathrm{C}$ to handle the loading rate of biodegradable influent

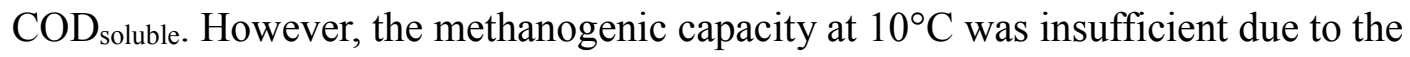


Table 4.4 SMA, stability, VSS, SRT, and methanogenic capacity of the UASB-digester system treating municipal wastewater at $10-20^{\circ} \mathrm{C}$, and BMP of influent $\mathrm{COD}_{\text {soluble }}$ rate. The standard deviation is in the brackets.

\begin{tabular}{|c|c|c|c|c|c|c|c|c|c|c|c|}
\hline Temperature & UASB & Digester & UASB & Digester & UASB & Digester & $\begin{array}{c}\text { SRT } \\
\text { UASB- } \\
\text { Digester }\end{array}$ & $\begin{array}{l}\text { UASB } \\
\text { at } 35^{\circ} \mathrm{C}\end{array}$ & $\begin{array}{l}\text { Digester } \\
\text { at } 35^{\circ} \mathrm{C}\end{array}$ & $\begin{array}{c}\text { UASB } \\
\text { ow temperatures }\end{array}$ & $\begin{array}{c}\text { Influent soluble } \\
\text { BMP }\end{array}$ \\
\hline${ }^{\circ} \mathrm{C}$ & \multicolumn{2}{|c|}{$\begin{array}{c}\mathrm{g} \mathrm{CH}_{4} \mathrm{COD} \\
/(\mathrm{gVSS} \mathrm{d})\end{array}$} & \multicolumn{2}{|c|}{$\begin{array}{c}\mathrm{g} \mathrm{CH}_{4} \mathrm{COD} \\
\text { / g sludge COD }\end{array}$} & \multicolumn{2}{|c|}{$\mathrm{g} / \mathrm{L}$} & (d) & \multicolumn{3}{|c|}{$\mathrm{g} \mathrm{CH}_{4} \mathrm{COD} / \mathrm{d}$} & $\mathrm{g} \mathrm{CH}_{4} \mathrm{COD} / \mathrm{d}$ \\
\hline 17.5 & $\begin{array}{c}0.28 \\
(0.02)\end{array}$ & $\begin{array}{c}0.27 \\
(0.02)\end{array}$ & $\begin{array}{c}0.24 \\
(0.03)\end{array}$ & $\begin{array}{c}0.18 \\
(0.03)\end{array}$ & $\begin{array}{c}9.0 \\
(1.1)\end{array}$ & $\begin{array}{c}7.9 \\
(0.6)\end{array}$ & $39-103$ & $\begin{array}{l}244 \\
(27)\end{array}$ & $105(17)$ & $64(7)$ & $33(2)$ \\
\hline 15 & $\begin{array}{c}0.24 \\
(0.02)\end{array}$ & $\begin{array}{c}0.29 \\
(0.01)\end{array}$ & $\begin{array}{c}0.28 \\
(0.03)\end{array}$ & $\begin{array}{c}0.21 \\
(0.02)\end{array}$ & $\begin{array}{l}10.7 \\
(0.6)\end{array}$ & $\begin{array}{c}9.0 \\
(0.8)\end{array}$ & $75-1670$ & $\begin{array}{l}268 \\
(12)\end{array}$ & $132(15)$ & $67(3)$ & $33(4)$ \\
\hline 10 & $\begin{array}{c}0.25 \\
(0.04)\end{array}$ & $\begin{array}{c}0.29 \\
(0.03)\end{array}$ & $\begin{array}{c}0.23 \\
(0.02)\end{array}$ & $\begin{array}{c}0.20 \\
(0.01)\end{array}$ & $\begin{array}{l}10.3 \\
(0.8)\end{array}$ & $\begin{array}{c}8.0 \\
(0.70)\end{array}$ & $42-69$ & $\begin{array}{l}279 \\
(36)\end{array}$ & $119(11)$ & $31(4)$ & $46(4)$ \\
\hline
\end{tabular}


significant increase of the $\mathrm{COD}_{\text {soluble }}$ loading rate during this period. The average stability of the digester sludge and UASB sludge was $0.20 \pm 0.01$ and $0.25 \pm 0.02 \mathrm{CH}_{4}$ $\mathrm{COD} / \mathrm{g}$ sludge $\mathrm{COD}$, respectively. The average SMA of the digester and UASB sludge was respectively $0.28 \pm 0.01$ and $0.26 \pm 0.02 \mathrm{CH}_{4} \mathrm{COD} /(\mathrm{g}$ VSS d). SRT of the UASBdigester system was longer than $39 \mathrm{~d}$.

\subsubsection{Microbial community analysis}

Real-time PCR analysis revealed similar levels of total Bacteria and total Archaea (assumed to be methanogens) in the UASB sludge and in the digester sludge, irrespective of temperature (Fig.4.6a and 4.6b). Total bacteria count in the influent and effluent samples were similar, and on average a factor 10 lower than in the UASB sludge and digester sludge. In contrast, total Archaea were, with the exception of the sample at $20^{\circ} \mathrm{C}$, a factor 10 lower in the influent compared to the effluent. Nonetheless, total Archaea were still a factor 20-40 lower in the effluent compared to the UASB and digester samples.

A more detailed view on the methanogenic community revealed an overall dominance of the acetoclastic Methanosaetaceae and the hydrogenotrophic Methanomicrobiales (Fig.4.6c, 4.6d and 4.6e). A lower level of gene copies as found for the different methanogenic groups and total methanogens, could be observed in the influent and effluent samples compared to the UASB sludge and the digester sludge. The methanogenic community was similar in the digester and UASB samples. The number of gene copies of Methanosaetaceae were similar to Methanomicrobiales. However, Methanosaetaceae in the digester sludge showed a slight decrease in abundance at 12.5 and $10^{\circ} \mathrm{C}$, compared to the higher temperatures $\left(15-20^{\circ} \mathrm{C}\right)$. Methanobacteriales, although being less abundant, showed a clear increase at $10^{\circ} \mathrm{C}$. Methanosarcinaceae were not detected in any of the samples.

\subsection{Discussion}

The present research shows an overall average COD removal efficiency of $60.0 \pm 4.6 \%$ at temperatures between $12.5-20^{\circ} \mathrm{C}$. Latter is somewhat lower as compared to the results of Mahmoud et al. (2004) achieved at a UASB temperature of $15^{\circ} \mathrm{C}$, probably as a result of the lower applied $\mathrm{COD}_{\text {suspended }}$ to $\mathrm{COD}_{\text {soluble }}$ ratio in the domestic

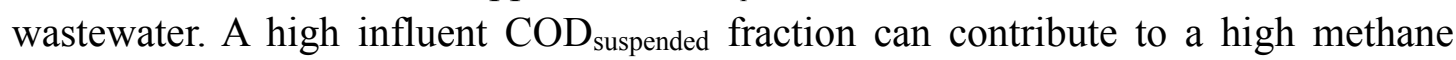
production and herewith a high methanogenic biomass production in the digester. Because this biomass is recirculated to the UASB reactor, it helps to enhance the methanogenic capacity of the UASB reactor and thus $\mathrm{COD}_{\text {soluble removal. }}$

The present results showed that even at temperatures as low as $12.5^{\circ} \mathrm{C}$ the methanogenic capacity of the UASB reactor was sufficient to maintain an effluent $\mathrm{COD}_{\text {soluble }}$ concentration of $91 \mathrm{mg} \mathrm{COD} / \mathrm{L}$. However, lower temperatures $\left(10^{\circ} \mathrm{C}\right)$, accompanied by higher influent COD loading rate resulted in an overloading of the UASB reactor and higher effluent concentrations. Zhang et al (2013) show that such 


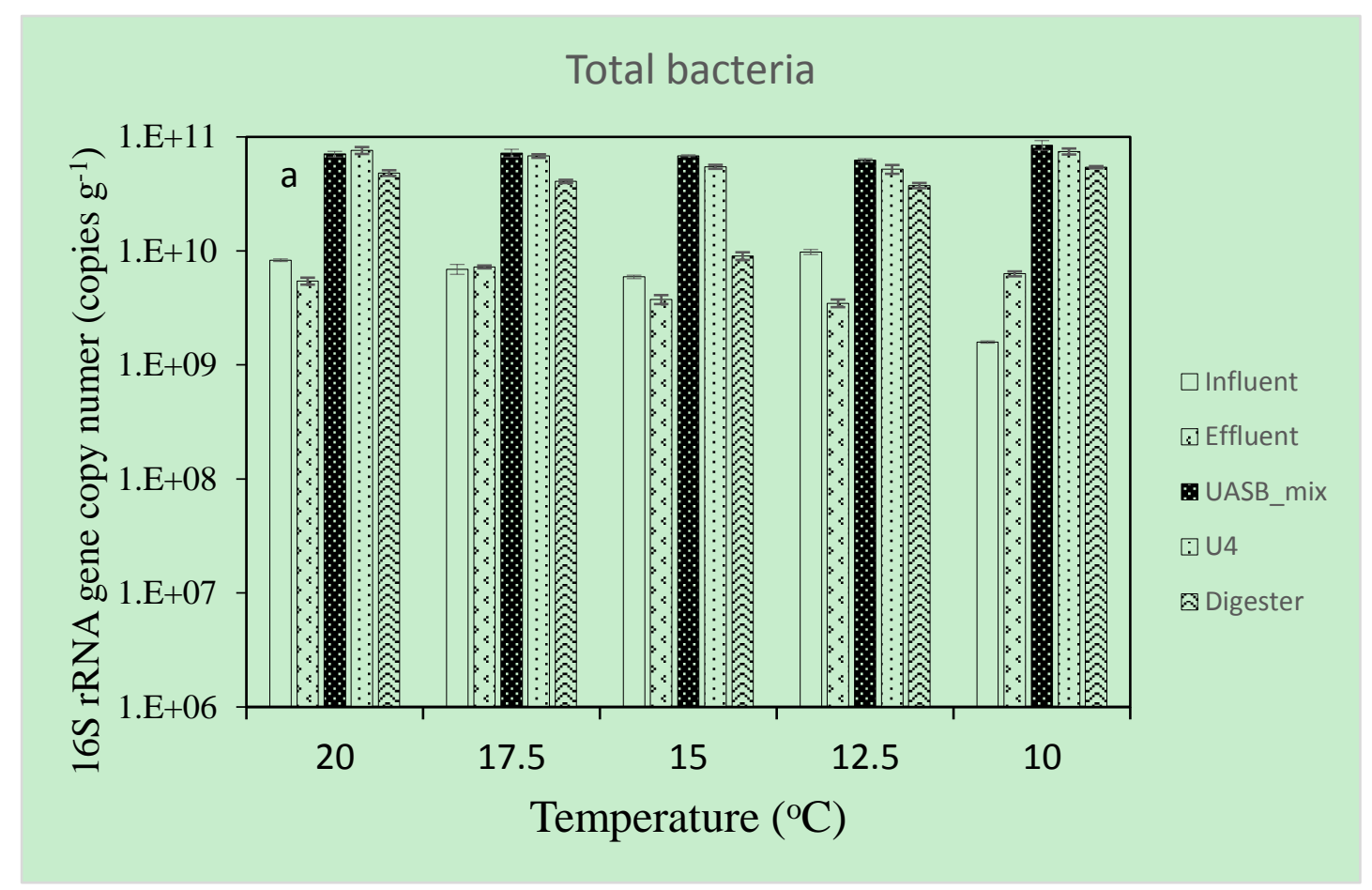

\section{Total methanogens}

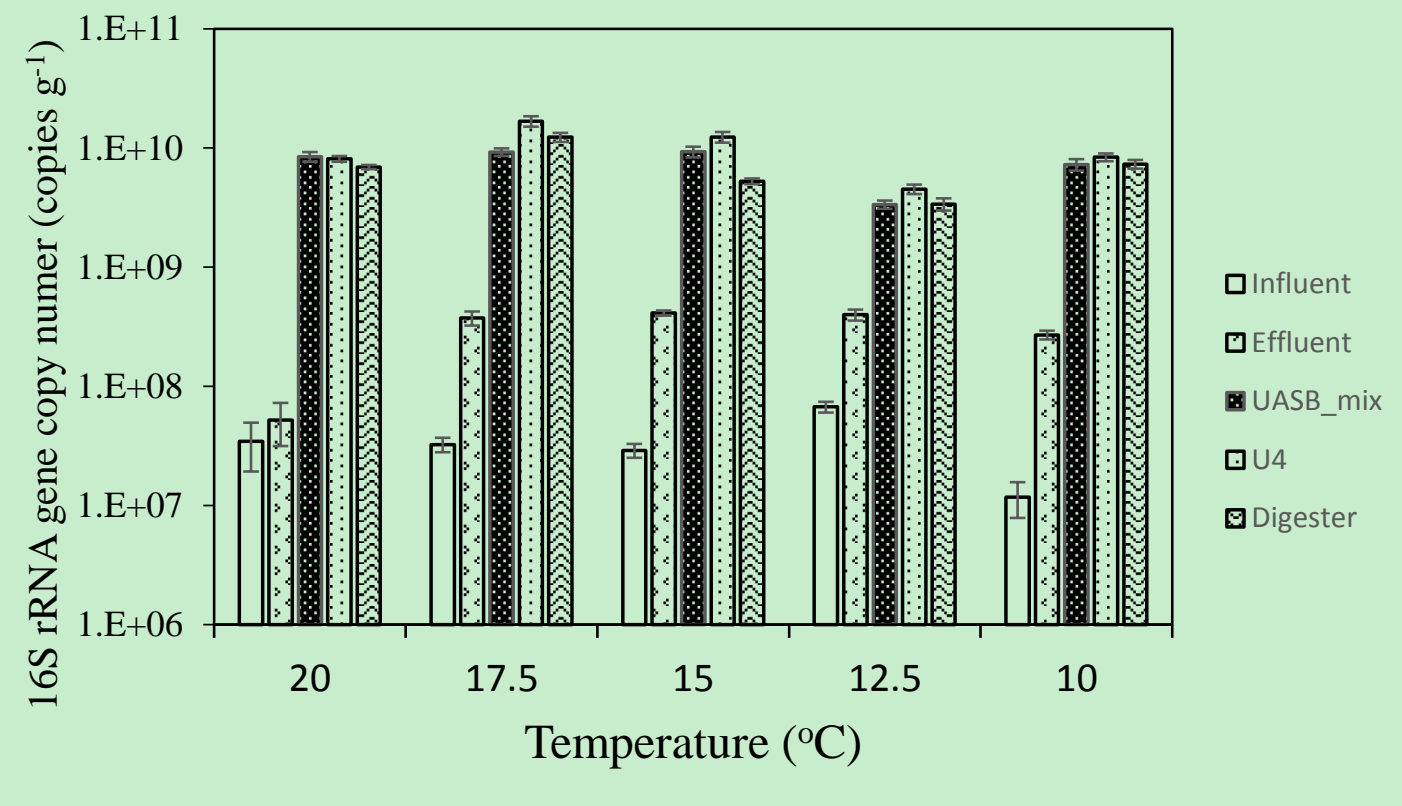

Fig.4.6 Microbial community of the UASB-digester treating municipal wastewater at subsequently $20,17.5,15,12.5$ and $10^{\circ} \mathrm{C}$. a: total bacteria, b: total methanogens, c: methanosaetaceae, d: methanobacteriales, e: methanomicrobiales 


\section{Methanosaetaceae}

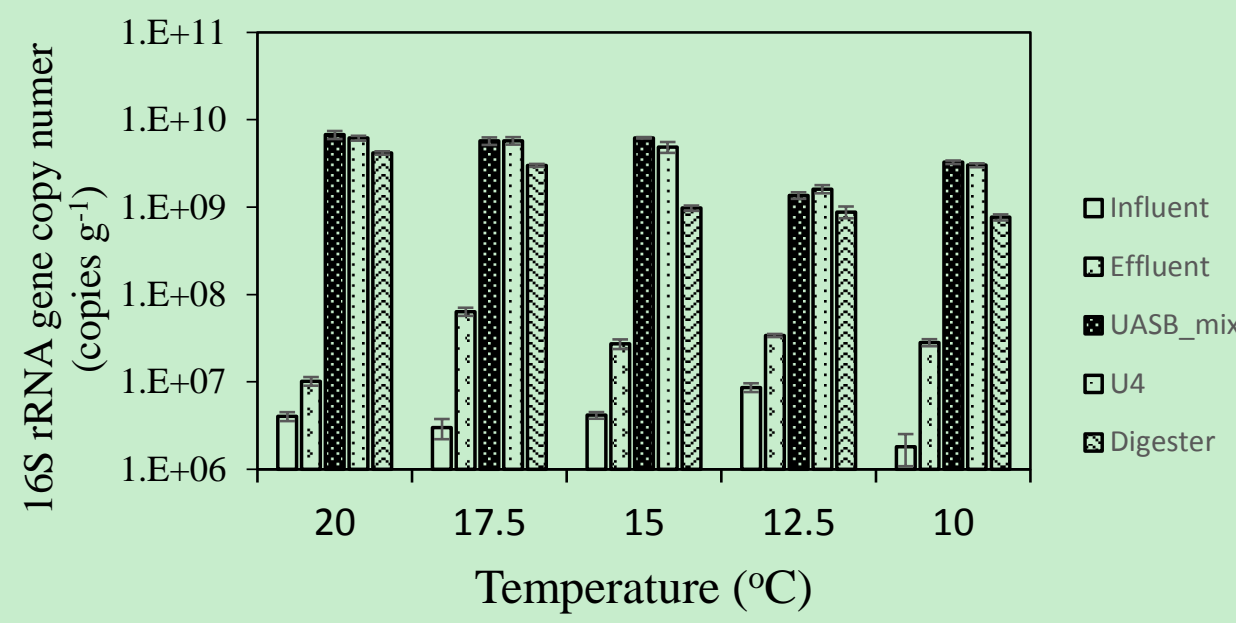

\section{Methanobacteriales}

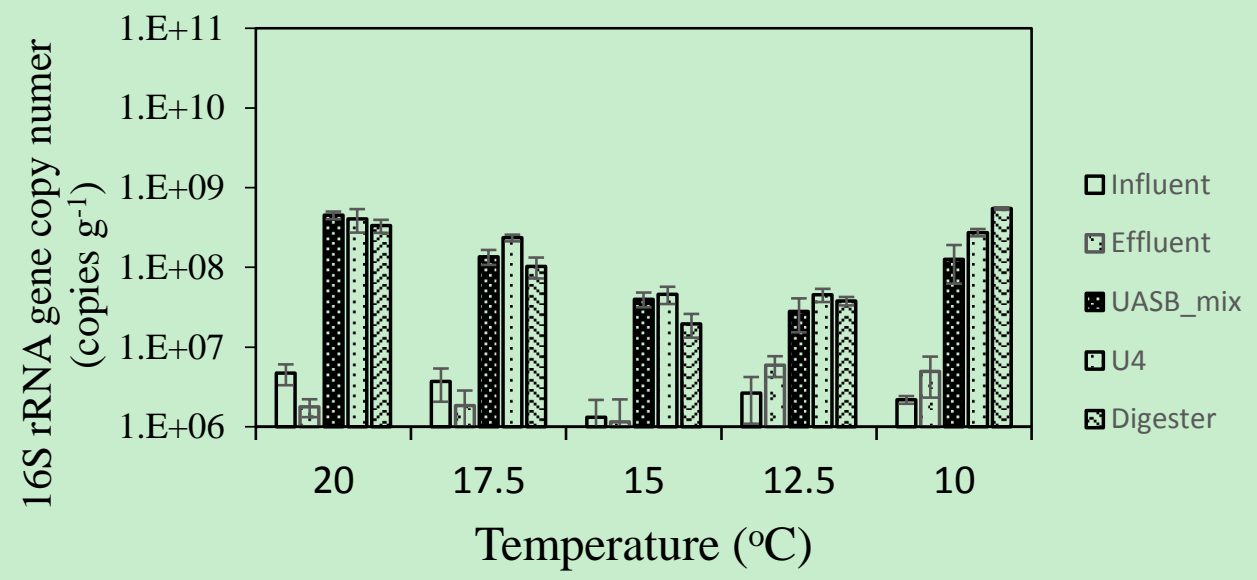

\section{Methanomicrobiales}

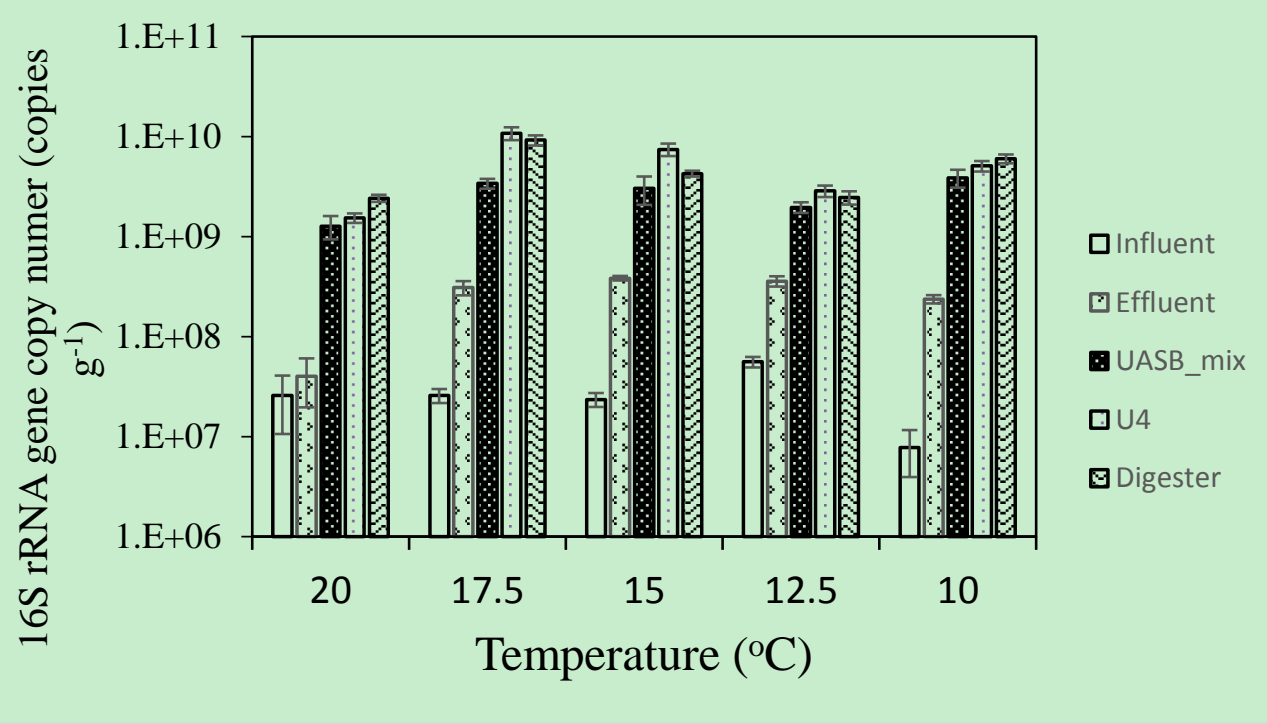


lower performance could be mitigated by a (temporary) extra addition of COD to the digester (so called co-digestion) to increase the growth of methanogens and other anaerobic biomass for extra $\mathrm{COD}_{\text {soluble }}$ conversion in the UASB after the sludge recirculation.

Approximately $38 \%$ of the influent biodegradable $\mathrm{COD}_{\text {suspended }}$ could already be hydrolyzed in the UASB reactor, in spite of the low temperatures. No significant difference was shown for the hydrolysis of influent $\mathrm{COD}_{\text {suspended }}$ at the different applied temperatures due to the large standard deviation of $\mathrm{COD}_{\text {soluble removal. Also other }}$ studies towards UASB-digester systems showed a substantial hydrolysis in the UASB reactor at lower temperatures (Álvarez et al., 2004; Mahmoud et al., 2004; Zhang et al., 2013; Zhang et al., 2012). In contrast, the hydrolytic efficiency of organic solids in a separate UASB reactor at $15^{\circ} \mathrm{C}$ only was $25 \%$, when operated at an HRT of $6 \mathrm{~h}$ (Mahmoud et al., 2004). Evidently in the UASB-digester system excess hydrolytic enzymes are recirculated to the UASB reactor and increase hydrolysis at low temperatures (Zhang et al., 2016a). However, it results in an additional COD soluble load and therefore increases the required methanogenic capacity in the UASB reactor. Latter should be taken into account when designing a UASB-digester.

Due to incomplete hydrolysis of wastewater $\mathrm{COD}_{\text {suspended, }}$ extra $\mathrm{COD}_{\text {colloidal }}$ may be produced in the UASB reactor. Thus, it was overloading at $10^{\circ} \mathrm{C}$. For aerobic reactors it is known that lower temperatures have a negative effect on the flocculation of

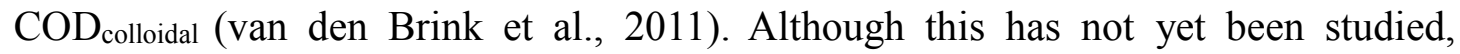
anaerobic sludge flocculation at low temperatures could be poor as well.

The measured effluent dissolved methane of $74 \mathrm{mg}$ COD /L, corresponding to a production rate of $37 \mathrm{~g} \mathrm{CH}_{4} \mathrm{COD} / \mathrm{d}$, did not increase when temperature of the UASB reactor decreased. This is in agreement with Matsuura et al. (2015), who found that the dissolved methane concentration only exhibited small changes between $23.5-28^{\circ} \mathrm{C}$ and 14.6-24. $2^{\circ} \mathrm{C}$, i.e. 74 and $72 \mathrm{mg} \mathrm{CH} 4 \mathrm{COD} / \mathrm{L}$, respectively. Souza et al. (2011) found a similar dissolved methane concentration when applying a UASB reactor treating domestic wastewater at $25^{\circ} \mathrm{C}$. However, the dissolved methane was oversaturated at the applied mesophilic conditions. The saturated dissolved methane production based on the solubility of methane at 10 and $20^{\circ} \mathrm{C}$ should be 84 and $46 \mathrm{~g} \mathrm{CH}_{4} \mathrm{COD} / \mathrm{d}$, respectively (Yamamoto et al., 1976). Therewith, methane in the liquid phase in this study was not saturated at $10-20^{\circ} \mathrm{C}$. The low dissolved methane concentration was probably due to the low total methane production of the UASB reactor.

Post treatment of the UASB-digester effluent at $242 \mathrm{mg} \mathrm{COD} / \mathrm{L}$ is required to reach effluent COD standards (e.g. EU standard of $125 \mathrm{mg} / \mathrm{L}$ ). Downflow hanging sponge (DHS) reactors, rotating biological contactors and trickling filter systems can be alternatives to achieve such an effluent concentration (Beas et al., 2015; Chernicharo et al., 2015; De Almeida et al., 2009; Tawfik et al., 2003). Because methane has a strong global warming potential ( 25 times the one for carbon dioxide), the dissolved methane in the effluent of $74 \mathrm{mg} \mathrm{COD/L}$ should be removed or, preferably, recovered. Hollowfiber membranes and a poly-di-methyl-siloxane (PDMS) membrane contactor were 
tested for degasification and to strip the dissolved methane using nitrogen gas, respectively (Cookney et al., 2012; Hatamoto et al., 2010). In this manner $72 \%$ and $86 \%$ of the dissolved methane were recovered, respectively. Two stages of DHS were applied to subsequently remove the remaining effluent dissolved methane (Matsuura et al., 2015). $58-88 \%$ of the dissolved methane was recovered in the first stage, and the residual dissolved methane was almost completely oxidized in the second stage. However, the economic assessment and energy consumption should be considered before applying these technologies.

Methane production of the digester accounted for half of the total methane production, which was higher than the 14\% and 33\% reported by Mahmoud et al. (2004) and Álvarez et al. (2004), respectively. The higher methane production of the digester in this study was attributed to the higher sludge recirculate rate of $16 \%$ of the influent flow rate, resulting in more influent $\mathrm{COD}_{\text {suspended }}$ transfer to the digester. This also gave a very low $\mathrm{COD}_{\text {suspended }}$ accumulation in the UASB-digester system and herewith a relatively long SRT ( $>39$ d). The latter resulted in an improved stability of the UASB sludge ( $0.25 \mathrm{~g} \mathrm{CH}_{4} \mathrm{COD} / \mathrm{g} \mathrm{COD}$ ) compared to stabilities reported by Mahmoud et al. (2004) of $0.36 \mathrm{~g} \mathrm{CH}_{4} \mathrm{COD} / \mathrm{g} \mathrm{COD}$. Also the SMA of the UASB sludge and digester sludge of 0.26 and $0.28 \mathrm{~g} \mathrm{CH}_{4} \mathrm{COD} /(\mathrm{g} \mathrm{VSS} \mathrm{d})$ were considerably higher than the results reported by Álvarez et al. (2004) of 0.079 and $0.125 \mathrm{~g} \mathrm{CH}_{4} \mathrm{COD} /(\mathrm{g} \mathrm{VSS} \mathrm{d}$ ) (SMA were measured at $35^{\circ} \mathrm{C}$ ).

Energy cost for heating the sludge recirculated from the UASB reactor to the digester depends on sludge recirculation rate. The sludge recirculation rate in this study was $16 \%$ of the influent flow rate. In steady state, no accumulation was found because the high sludge recirculation resulted in a low sludge production. The sludge recirculation rate can be further optimized with respect to energy production, minimizing energy consumption and minimizing the digester volume. Under the applied sludge recirculation rate, methane production can compensate for only $20 \%$ of the heating energy at $10^{\circ} \mathrm{C}$ (see supporting material in Annex 3). In practice, sludge recirculation might be small as the VSS concentration of a full scale UASB reactor treating domestic sewage can be expected to be relative high (about $30 \mathrm{~g} / \mathrm{L}$ ) compared with this study (Florencio et al., 2001). Two alternatives can be used to reduce the heating energy. One is to operate the digester at a lower temperature, e.g. $25-30^{\circ} \mathrm{C}$ instead of $35^{\circ} \mathrm{C}$. A second option would be to concentrate the UASB sludge by sedimentation, thus reducing the amount of water that needs to be recirculated. Furthermore, a heat exchanger could be installed for the recirculated sludge. The energy of the recirculated digester sludge $\left(35^{\circ} \mathrm{C}\right)$ can be reused for heating the recirculated UASB sludge $\left(10^{\circ} \mathrm{C}\right)$.

Methanomicrobiales and Methanosaetaceae were equally dominant methanogens found in the UASB-digester system during $10-20^{\circ} \mathrm{C}$. These methanogens are classified with a high affinity for the substrate. This was identified by the fact that the methane production of the UASB reactor (including dissolved methane) matched well with the methanogenic capacity at $12.5-20^{\circ} \mathrm{C}$. Acetoclastic methanogens and hydrogenotrophic methanogens are the two major populations for methane production (Demirel \& Scherer, 2008). A similar composition of the microbial community was observed during 
domestic wastewater treatment in an UASB reactor at $20^{\circ} \mathrm{C}$ (Saha et al., 2015). This shows that both acetoclastic and hydrogenotrophic pathways are used for methane production at low temperatures. As the biomass was alternatingly exposed to mesophilic and (almost) psychrophilic conditions, it may be that mesophilic selection out competes the psychrophilic selection, or that reaching equilibrium takes an even longer time. However, Bialek et al. (2014) and Bandara et al. (2012) showed that, although both pathways can take place, hydrogenotrophic methanogenesis appears to be the main pathway for methane production at low temperatures, which might explain the apparent increase in abundance of Methanobacteriales at $10^{\circ} \mathrm{C}$ in the UASBdigester system. In contrast, aceticlastic methanogens were abundant when a benchscale anaerobic membrane bioreactor (AnMBR) equipped with submerged flat-sheet microfiltration membranes was operated at $15^{\circ} \mathrm{C}$ treating domestic wastewater (Smith et al., 2013).

The here presented reactor system can become a key technology within a more sustainable treatment scheme for treatment of domestic wastewater as compared to nowadays generally applied conventional activated sludge processes. Coupling this anaerobic system with i.e DAMO technology (Kampman et al, 2012) can mitigate the detrimental $\mathrm{CH}_{4}$ emission and link that with nitrogen removal. An interesting technique for removal and recovery of phosphorus was recently published by Drenkova-Tuhtan et al. (2016), applying nanocomposite magnetic particles for adsorption and desorption of phosphate from wastewater.

Bio-flocculation followed by anaerobic sludge digestion, as applied in the AB process, is referred to as another alternative for activated sludge treatment (Verstraete et al., 2009), and sewage organic matter from which methane can be produced by anaerobic sludge digestion (Faust et al., 2014). Main advantage as compared to direct anaerobic treatment of domestic sewage is the absence of dissolved methane in the liquid anaerobic effluent. However, it needs an energy input of $0.03 \mathrm{kWh} / \mathrm{m}^{3}$ (wastewater) for aeration (Khiewwijit et al. 2015).

\subsection{Conclusions}

A pilot scale UASB-digester treating domestic wastewater at $10-20^{\circ} \mathrm{C}$ at an $\mathrm{HRT}$ of 6 h:

- Achieved a stable COD removal efficiency of $60 \pm 4.6 \%$, while temperature decreased from $20-12.5^{\circ} \mathrm{C}$ at an influent COD concentration of $616 \pm 140 \mathrm{mg} / \mathrm{L}$;

- Achieved, at $10^{\circ} \mathrm{C}$ a COD removal efficiency of $51.5 \pm 5.5 \%$; reduction in COD removal efficiency is mainly due to an increased influent COD concentration from $514 \pm 110$ at $12.5^{\circ} \mathrm{C}$ to $764 \pm 124 \mathrm{mg} / \mathrm{L}$;

- Achieved a high $\mathrm{COD}_{\text {suspended }}$ removal efficiency of $76.0 \pm 9.1 \%$;

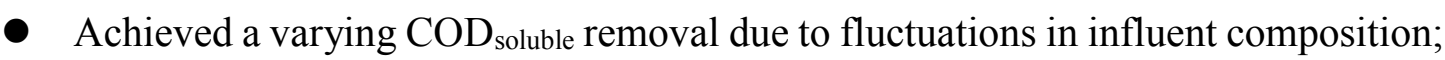
effluent COD concentration maintained $90 \pm 23 \mathrm{mg} / \mathrm{L}$ at 12.5 to $20^{\circ} \mathrm{C}$; 
- Achieved a methane yield of $40 \pm 4 \%$ of the influent COD, which was $80 \%$ of the influent BMP. $49 \%$ of the total methane production, was produced in the low temperature UASB reactor, and the remainder in the digester. Discharge sludge accounted for $8 \pm 5 \%$ of influent COD;

- Resulted in a stable SMA of the UASB sludge and the digester sludge of $0.26 \pm$ 0.03 and $0.29 \pm 0.03 \mathrm{~g} \mathrm{CH}_{4} \mathrm{COD} /(\mathrm{g}$ VSS d); the stability of the UASB sludge and the digester sludge was stable at $0.25 \pm 0.02$ and $0.20 \pm 0.02 \mathrm{~g} \mathrm{CH}_{4} \mathrm{COD} / \mathrm{g} \mathrm{COD}$;

- Resulted in a microbial population where Acetoclastic Methanosaetaceae and hydrogenotrophic Methanomicrobiales were the dominant methanogens.

\section{Acknowledgements}

The authors thank STOWA (Foundation for Applied Water Research), Paques BV, RVO (Netherlands Enterprise Agency), Hoogheemraadschap de Stichtse Rijnlanden, Hoogheemraadschap van Rijnland, Waterschapsbedrijf Limburg, Waterschap Drents Overijsselse Delta, Waterschap Rivierenland en Waternet for supporting this research. De Vrieze is supported as a postdoctoral fellow by the Research Foundation Flanders (FWO- Vlaanderen). 


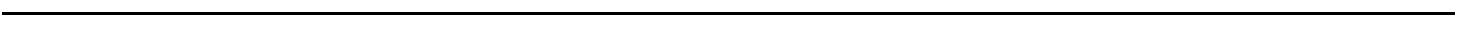




\section{Hydrolysis rate constants at $10-25^{\circ} \mathrm{C}$ can be more than doubled by a short anaerobic pre- hydrolysis at $35^{\circ} \mathrm{C}$}

Zhang, L., Gao, R., Naka, A., Hendrickx, T.L.G., Rijnaarts, H.H.M., Zeeman, G.

This chapter has been accepted for publication in Water Research, 2016

Dio:10.1016/j.watres.2016.07.038 


\begin{abstract}
Hydrolysis is the first step of the anaerobic digestion of complex wastewater and considered as the rate limiting step especially at low temperature. Low temperature (10$25^{\circ} \mathrm{C}$ ) hydrolysis was investigated with and without application of a short prehydrolysis at $35^{\circ} \mathrm{C}$. Batch experiments were executed using cellulose and tributyrin as model substrates for carbohydrates and lipids. The results showed that the low temperature anaerobic hydrolysis rate constants increased by a factor of 1.5 to 10 , when the short anaerobic pre-hydrolysis at $35^{\circ} \mathrm{C}$ was applied. After the pre-hydrolysis phase at $35^{\circ} \mathrm{C}$ and decreasing the temperature, no lag phase was observed in any case. Without the pre-hydrolysis, the lag phase for cellulose hydrolysis at $35-10^{\circ} \mathrm{C}$ was $4-30$ days. Tributyrin hydrolysis showed no lag phase at any temperature. The hydrolysis efficiency of cellulose increased from 40 to $62 \%$, and from 9.6 to $40 \%$ after 9.1 days at 15 and $10^{\circ} \mathrm{C}$, respectively, when the pre-hydrolysis at $35^{\circ} \mathrm{C}$ was applied. The hydrolysis efficiency of tributyrin at low temperatures with the pre-hydrolysis at $35^{\circ} \mathrm{C}$ was similar to those without the pre-hydrolysis. The hydrolytic activity of the supernatant collected from the digestate after batch digestion of cellulose and tributyrin at $35^{\circ} \mathrm{C}$ was higher than that of the supernatants collected from the low temperature $\left(\leq 25^{\circ} \mathrm{C}\right)$ digestates.
\end{abstract}




\subsection{Introduction}

Anaerobic treatment of municipal wastewater is attractive as it has low operational costs, produces low amounts of excess sludge and recovers energy in the form of methane compared with traditional aerobic wastewater treatment (Chong et al., 2012). Temperature of municipal wastewater in large parts of the world is lower than favourable for anaerobic treatment at least when a short hydraulic retention time (HRT) is applied. Low temperature methanogenesis has recently been intensively studied (McKeown et al., 2012; McKeown et al., 2009a; O'Reilly et al., 2009). Chemical oxygen demand (COD) removal efficiencies of 82 - $92 \%$ were achieved at a temperature range of $4-15^{\circ} \mathrm{C}$ applying anaerobic reactors such as an expanded granular sludge bed (EGSB) reactor, a combined EGSB-anaerobic filter (AF) reactor, and an anaerobic membrane bioreactor (AnMBR) for the treatment of mainly soluble COD

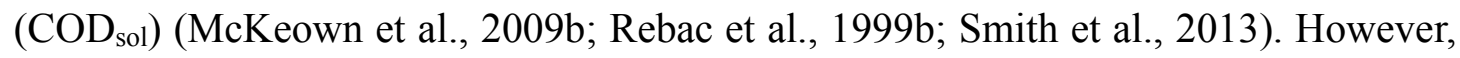
studies on low temperature anaerobic hydrolysis are scarce.

Hydrolysis is the first step of the anaerobic digestion of complex wastewater and considered as the rate limiting step (Hendriks \& Zeeman, 2008; Lettinga et al., 2001; Pavlostathis \& Giraldo-Gomez, 1991b). Zeeman (1991b) reported on the hydrolysis of suspended $\mathrm{COD}\left(\mathrm{COD}_{\mathrm{ss}}\right)$ during the batch digestion of cow manure; hydrolysis efficiency increased from 12 to $27 \%$ as temperatures increased from 5 to $25^{\circ} \mathrm{C}$ during 125 days of batch digestion. When operating an upflow anaerobic sludge blanket (UASB) reactor for domestic sewage treatment at an HRT of $3 \mathrm{~h}$ and $17^{\circ} \mathrm{C}$, the particulate organic matter was effectively removed by entrapment in the sludge bed, but the hydrolysis efficiency of the entrapped organics was only $0.7 \%$ (Zeeman et al., 1997). Uemura and Harada (2000) showed a drop in the hydrolysis efficiency from 58\% at $25^{\circ} \mathrm{C}$ to $33 \%$ at $13^{\circ} \mathrm{C}$, when studying sewage treatment applying a UASB reactor at an HRT of $4.7 \mathrm{~h}$ and $25-13^{\circ} \mathrm{C}$. Also the anaerobic treatment of black water in a UASBseptic tank was shown to have a poor performance during the winter period (temperature lower than $14^{\circ} \mathrm{C}$ ): $60 \%$ of the influent COD was accumulated as solids in the sludge bed while about $30 \%$ was discharged as $\mathrm{COD}_{\text {sol }}$ with the effluent (Luostarinen et al., 2007).

Novel anaerobic reactors are being developed to prolong sludge retention time (SRT) to improve hydrolysis efficiency at low temperatures. The hydrolysis of domestic sewage $\mathrm{COD}_{\mathrm{ss}}$ in an $\mathrm{AF}$ or anaerobic hybrid $(\mathrm{AH})$ reactor was respectively 11.8 and $12.3 \%$ at $13^{\circ} \mathrm{C}$, when operated at an HRT of $4 \mathrm{~h}$ (Elmitwalli et al., 2002b), but increased to $36.7-42.2 \%$ in a combined AF-AH system at an HRT of 2-4-4-8 h (Elmitwalli et al., 2002a). A UASB-digester system for low temperature domestic sewage treatment includes a mesophilic digester to stabilize the influent organic solids captured in the UASB sludge (Álvarez et al., 2004; Mahmoud et al., 2004). The hydrolysis efficiency in a UASB-digester system increased from 25 to $44 \%$ compared with a single UASB reactor (Mahmoud et al., 2004). In such a UASB-digester system, Zhang et al. (2012) and Zhang et al. (2013) observed an increased hydrolysis activity in the low temperature 
UASB reactor treating domestic sewage. The hydrolysis occurring in the UASBdigester system was achieved with sludge that was exposed to an alternating temperature, as the sludge was recirculated between the low temperature UASB reactor and the mesophilic digester. The low temperature hydrolysis in the UASB reactor was initiated with a temporary start-up at $35^{\circ} \mathrm{C}$ achieved in the digester. The pre-hydrolysis at $35^{\circ} \mathrm{C}$ could excrete excess hydrolytic enzymes which facilitates hydrolysis. However, the effects of a pre-hydrolysis at $35^{\circ} \mathrm{C}$ on low temperature anaerobic hydrolysis are not reported in literature.

The hydrolysis of organic solids in anaerobic digestion can be described by first order kinetics (Batstone et al., 2002; Vavilin et al., 1996). Methane can be considered as the main hydrolysis product if hydrolysis is the slowest step compared to acidification and methanogenesis (Veeken \& Hamelers, 1999). The hydrolysis rate constant can differ due to various experimental conditions such as inoculum source, ratio of biomass and substrate, and available surface of substrate (Sanders et al., 2000; Vavilin et al., 2008).

The main goal of the present research is to investigate the effect of a pre-hydrolysis at $35^{\circ} \mathrm{C}$ on low temperature anaerobic hydrolytic activities. Real domestic sewage was purposely not applied as a substrate to rule out potential effects of unknown components present in domestic sewage. Tributyrin and cellulose were used as model compounds for lipids and carbohydrates, of which hydrolysis rates at $35^{\circ} \mathrm{C}$ have been reported previously in literature (Fernandez et al., 2014 and O'Sullivan et al, 2008). Batch hydrolysis experiments were executed at low temperature $\left(10-25^{\circ} \mathrm{C}\right)$ after applying a short start-up at $35^{\circ} \mathrm{C}$. The results with a pre-hydrolysis at $35^{\circ} \mathrm{C}$ were compared with low temperature $\left(10-25^{\circ} \mathrm{C}\right)$ hydrolysis without the mesophilic pre-hydrolysis. The supernatant in the hydrolysis tests was collected at $10-35^{\circ} \mathrm{C}$, and its hydrolytic activity was tested.

\subsection{Material and Methods}

\subsubsection{Inoculum}

Granular sludge originating from a mesophilic anaerobic reactor treating paper-mill wastewater in Eerbeek (NL) was used as inoculum for hydrolysis rate constant tests. The inoculum had been stored at $4^{\circ} \mathrm{C}$ in gas-tight plastic containers for 2 weeks. The inoculum was incubated at $35^{\circ} \mathrm{C}$ for 2 weeks without feeding and subsequently washed to remove biodegradable material before conducting hydrolysis experiments.

Digester sludge from a pilot scale UASB $\left(10-12.5^{\circ} \mathrm{C}\right)$ digester $\left(35^{\circ} \mathrm{C}\right)$ system treating domestic wastewater was used as inoculum for determining the hydrolytic activity, released to the supernatant phase at $10-35^{\circ} \mathrm{C}$. Detailed operational parameters of the pilot scale UASB-digester are reported by Zhang et al. (2016b). The digester sludge was, after collection, placed in a cabinet at $35^{\circ} \mathrm{C}$ for $2-3$ days to stabilize and concentrate the sludge. 


\subsubsection{Determination of hydrolysis rate constants at constant}

\section{temperatures}

First order hydrolysis rate constants of cellulose (Sigmacell® type 50) and tributyrin (Fluka, $\geq 98 \%$ ) were determined at different temperatures. Applied conditions for determining the hydrolysis rate constants are shown in Table 5.1 and 5.2. Blanks were executed at the same conditions but without adding substrate and used to correct for hydrolysis of organic materials (including biomass) present in the inoculum. All tests were executed in duplicate. A Bioprocess Control Instrument (AMPTS II, Sweden) was used for determining the methane production for tributyrin hydrolysis. For cellulose using granular sludge as inoculum, serum bottles of $120 \mathrm{ml}$ volume closed with rubber stoppers and aluminium clamps were used. The inoculum was $10 \mathrm{ml}$ at 35 and $25^{\circ} \mathrm{C}$, and increased to $20 \mathrm{ml}$ at 15 and $10^{\circ} \mathrm{C}$ to prevent the accumulation of intermediate products. Volume of inoculums at $25-35^{\circ} \mathrm{C}$ was lower than $10-15^{\circ} \mathrm{C}$ to compensate for the higher activity. Methane production of the cellulose tests was monitored by determining the gas composition and the pressure of the headspace. Gas samples size was $0.05 \mathrm{ml}$. Pressure of the headspace was measured daily using a manual pressure meter (GMH 3150, Germany). For cellulose hydrolysis, using the digester sludge as inoculum, methane production at 35 and $25^{\circ} \mathrm{C}$ was monitored by Bioprocess Control Instrument (AMPTS II, Sweden).

\section{Dissolved products}

$0.4 \mathrm{ml}$ liquid samples were collected to determine $\mathrm{COD}_{\text {sol }}$ concentrations. For cellulose, additionally volatile fatty acids (VFA) and glucose were measured; for tributyrin, additionally VFA and glycerol were measured. The frequency of $\mathrm{COD}_{\text {sol }}$ measurement depended on the hydrolysis efficiency with time.

\subsubsection{Effects of a short pre-hydrolysis at $35^{\circ} \mathrm{C}$ on low temperature}

\section{hydrolysis}

Next to above described hydrolysis tests, similar tests were executed with a short prehydrolysis at $35^{\circ} \mathrm{C}$. To make sure that hydrolysis had started with the pre-hydrolysis, temperature was decreased to 25,15 or $10^{\circ} \mathrm{C}$ after $3.3,3.1$ and 2.2 days, respectively, for cellulose and after 0.08 days for tributyrin. The difference in pre-hydrolysis time was due to practical considerations. The cooling process was, for each temperature, finished within 15 minutes. A Bioprocess Control Instrument (AMPTS II, Sweden) was applied for all experiments. The serum bottles were transferred to a foam box with ice water and manually mixed for cooling. One sample was added for monitoring the decrease of temperature using a thermometer. Samples were cultivated in coolers (Waeco, Germany) as the temperature reached the targeted value. 
Table 5.1 Applied conditions for determining the hydrolysis rate constants of cellulose and tributyrin at different temperatures

\begin{tabular}{|c|c|c|c|c|c|}
\hline & Cellulose & Tributyrin & \multicolumn{2}{|c|}{ Cellulose } & utyrin \\
\hline Inoculum & \multicolumn{2}{|c|}{ Granular sludge } & \multicolumn{3}{|c|}{ Digester sludge } \\
\hline Temperature $\left({ }^{\circ} \mathrm{C}\right)$ & 35,$25 ; 15,10$ & $35 ; 25,20,15,10$ & 10,15 & 25,35 & $10-35$ \\
\hline Initial COD concentration $\left(\mathrm{g} \mathrm{L}^{-1}\right)$ & 5 & $2 ; 1.25$ & 0.78 & 0.95 & 0.95 \\
\hline Inoculum (ml) & $10 ; 20$ & 100 & 87 & 350 & 350 \\
\hline Buffer (ml) & $0.25 ; 0.5$ & 2.5 & - & - & - \\
\hline Volume of bottles (ml) & 120 & 600 & 250 & 600 & 600 \\
\hline Distilled water (ml) & $5 ; 35$ & $150 ; 300$ & 33 & 50 & 50 \\
\hline Mixing (rpm) & 120 & 120 & 120 & 120 & 120 \\
\hline Initial $\mathrm{pH}$ & 7.12 & 7.12 & 6.90 & 6.90 & 6.90 \\
\hline
\end{tabular}

- Not added 


\subsubsection{Hydrolytic activity of supernatant phase at $10-35^{\circ} \mathrm{C}$}

The supernatants of the cellulose and tributyrin hydrolysis tests using the digester sludge from $10-35^{\circ} \mathrm{C}$ were collected when the hydrolysis efficiency achieved its maximum at the prevailing temperatures. The supernatant phase was collected by centrifuging at 4,500 rpm (Firlabo SW9, France) for 15 mins. The volume of the supernatant was similar as in the hydrolysis tests. Cellulose and tributyrin were used as substrates (in Table 5.1). Hydrolytic activity of the supernatant collected from different temperatures was executed at $35^{\circ} \mathrm{C}$, and the procedure was similar as that of the hydrolysis rate constant tests described in paragraph 5.2.2.

Table 5.2 Details of the buffer solution

\begin{tabular}{|c|c|c|}
\hline Material & concentraion & unit \\
\hline $\mathrm{NH}_{4} \mathrm{Cl}$ & 4.10 & $\mathrm{~g} \mathrm{~L}^{-1}$ \\
\hline $\mathrm{KH}_{2} \mathrm{PO}_{4}$ & 0.90 & $\mathrm{~g} \mathrm{~L}^{-1}$ \\
\hline $\mathrm{CaCl}_{2} \cdot 2 \mathrm{H}_{2} \mathrm{O}$ & 0.20 & $\mathrm{~g} \mathrm{~L}^{-1}$ \\
\hline $\mathrm{MgSO}_{4} \cdot 7 \mathrm{H}_{2} \mathrm{O}$ & 0.22 & $\mathrm{~g} \mathrm{~L}^{-1}$ \\
\hline $\mathrm{FeCl}_{3} \cdot 4 \mathrm{H}_{2} \mathrm{O}$ & 4.80 & $\mathrm{mg} \mathrm{L}^{-1}$ \\
\hline $\mathrm{CoCl}_{2} \cdot 6 \mathrm{H}_{2} \mathrm{O}$ & 4.80 & $\mathrm{mg} \mathrm{L}^{-1}$ \\
\hline $\mathrm{MnCl}_{2} \cdot 4 \mathrm{H}_{2} \mathrm{O}$ & 1.20 & $\mathrm{mg} \mathrm{L}^{-1}$ \\
\hline $\mathrm{CuCl}_{2} \cdot 2 \mathrm{H}_{2} \mathrm{O}$ & 0.07 & $\mathrm{mg} \mathrm{L}^{-1}$ \\
\hline $\mathrm{ZnCl}_{2}$ & 0.12 & $\mathrm{mg} \mathrm{L}^{-1}$ \\
\hline $\mathrm{HBO}_{3}$ & 0.12 & $\mathrm{mg} \mathrm{L}^{-1}$ \\
\hline$\left(\mathrm{NH}_{4}\right) 6 \mathrm{Mo}_{7} \mathrm{O}_{24} \cdot 4 \mathrm{H}_{2} \mathrm{O}$ & 0.22 & $\mathrm{mg} \mathrm{L}^{-1}$ \\
\hline $\mathrm{Na}_{2} \mathrm{SeO}_{3} \cdot 5 \mathrm{H}_{2} \mathrm{O}$ & 0.24 & $\mathrm{mg} \mathrm{L}^{-1}$ \\
\hline $\mathrm{NiCl}_{2} \cdot 6 \mathrm{H}_{2} \mathrm{O}$ & 0.12 & $\mathrm{mg} \mathrm{L}^{-1}$ \\
\hline EDTA & 2.40 & $\mathrm{mg} \mathrm{L}^{-1}$ \\
\hline $\mathrm{HCl}(36 \%)$ & 0.002 & $\mathrm{ml} \mathrm{L}^{-1}$ \\
\hline Resazurin & 1.20 & $\mathrm{mg} \mathrm{L}^{-1}$ \\
\hline
\end{tabular}




\subsubsection{Analysis}

Samples for measuring dissolved products were prepared by dilution, centrifugation and filtration. The raw sample was diluted 8 times and then centrifuged using a Thermo Electron IEC Micromax centrifuge (with rotor Cat. No. 3590, USA) at 10,000 rpm for 5 minutes. The centrifuged sample was filtered through a $0.45 \mu \mathrm{m}$ membrane filter (Whatman 10401614, Germany). The filtrate was used for dissolved products analyses.

$\mathrm{COD}_{\text {sol }}$ concentration was tested by Dr.Lange cuvette (LCK 514, the Netherlands). Biogas composition of the cellulose hydrolysis, and VFA concentration of the cellulose and the tributyrin hydrolysis were tested by gas chromatograph as described by Zhang et al. (2013). Glycerol concentration was determined using a High Performance Liquid Chromatography (HPLC) (Alltech, USA) equipped with a Hi-Plex H column $(300 \times$ $6.5 \mathrm{~mm}$ ) (Varian part nr. 1F70-0830), a Refractive Index (RI-71) detector and a Gynkotek M480 high precision pump. The mobile phase was $5 \mathrm{mM} \mathrm{H}_{2} \mathrm{SO}_{4}$ at flow rate of $0.6 \mathrm{ml} \mathrm{minute^{-1 }}$. Glucose was determined by HPLC equipped with an OA-1000 organic acids column $(30 \mathrm{~cm}$ ID $6.5 \mathrm{~mm})\left(70^{\circ} \mathrm{C}\right)$, a Refractive Index (RI-71) detector and a Gynkotek M480 high precision pump. The mobile phase was $1.25 \mathrm{mmol} \mathrm{H}_{2} \mathrm{SO}_{4}$ at a flow rate of $0.4 \mathrm{ml}$ minute ${ }^{-1}$.

\subsubsection{Calculation}

Methane production during hydrolysis of the cellulose was calculated using equation (1):

$$
C H_{4 t}=\frac{P_{t} \cdot V_{h} \cdot C_{t}}{100 \cdot R \cdot T \cdot 64 \cdot V_{s}}
$$

Where:

$\mathrm{CH}_{4 \mathrm{t}}$ : Methane production at time $\mathrm{t}$ (in $\mathrm{mg} \mathrm{COD} \mathrm{L}{ }^{-1}$ );

$\mathrm{P}_{\mathrm{t}}$ : Pressure of the headspace at time $\mathrm{t}(\mathrm{in} \mathrm{Kpa)}$;

$\mathrm{V}_{\mathrm{h}}$ : Headspace of the serums (in $\mathrm{ml}$ );

$\mathrm{C}_{\mathrm{t}}$ : Methane composition in the headspace at time $\mathrm{t}$ (in \%);

$\mathrm{R}$ : Gas law constant (in $\mathrm{kJ} \mathrm{mol}^{-1} \mathrm{~K}^{-1}$ );

$\mathrm{T}$ : Absolute temperature (in $\mathrm{K}$ );

64: factor converting 1 mole of methane to $64 \mathrm{~g} \mathrm{COD;}$

$\mathrm{V}_{\mathrm{s}}$ : Volume of the sample solution (in $\mathrm{ml}$ ).

Hydrolysis efficiency (\%) was calculated using equation (2), and hydrolysis products were measured with time during each trial: 
Hydrolysis $(\%)=\operatorname{net} \sum_{t} C O D_{\text {hydrolysis products }} /\left(C O D_{0} \cdot f_{b}\right) \cdot 100$

Where:

COD hydrolysis products: for cellulose: $\mathrm{COD}_{\text {sol }}$ and methane; $\mathrm{COD}_{\text {hydrolysis products }}$ for tributyrin: VFAs, glycerol and methane, expressed as $\operatorname{mg~COD~L}^{-1}$;

$\mathrm{COD}_{0}$ : initial particulate substrate concentration (in $\mathrm{mg} \mathrm{COD} \mathrm{L}^{-1}$ );

$\mathrm{F}_{\mathrm{b}}$ : the highest biodegradability of substrate achieved in all temperatures (in \%).

The net cumulative hydrolysis products of the substrates were obtained after correction for the products of the blank.

In anaerobic digestion model No.1 (ADM1), the disintegration of solids is considered as the first step in anaerobic digestion of composites, such as dead biomass (Yasui et al., 2008). Because model substrates, cellulose and tributyrin, were used in this study, hydrolysis was considered as the first and rate limiting step. First-order hydrolysis model was used for the determination of the hydrolysis rate constant (equation 3).

$$
\frac{\mathrm{d} C O D_{t}}{\mathrm{dt}}=-k_{h} \cdot C O D_{t}
$$

Where:

$\mathrm{k}_{\mathrm{h}}$ : First order hydrolysis rate constant (in $\left.\mathrm{d}^{-1}\right)$;

t: Time (in day);

$\mathrm{COD}_{\mathrm{t}}$ : Biodegradable particulate substrate concentration at time $\mathrm{t}$ (in $\mathrm{mg}$ $\mathrm{COD} / \mathrm{L})$.

$\mathrm{COD}_{\mathrm{t}}$ was calculated (equation 4$)$ :

$$
C O D_{t}=C O D_{0} \cdot f_{b}-\text { net } \sum_{t} C O D_{\text {hydrolysis products }}
$$

$\mathrm{k}_{\mathrm{h}}$ was estimated by fitting the linear equation (5):

$$
\operatorname{Ln}\left(C O D_{t}\right)=-k_{h} \cdot t+\operatorname{Ln}\left(C O D_{0}\right)
$$

The Arrhenius equation was used to analysis the effects of temperature on hydrolysis constant of cellulose and tributyrin (equation 6).

$$
k_{h}=A \cdot e^{\frac{-E}{R \cdot T}}
$$

Where:

$\mathrm{k}_{\mathrm{h}}$ : Hydrolysis rate constant (in $\mathrm{d}^{-1}$ );
A: Arrhenius constant (in $\mathrm{d}^{-1}$ );
E: Activation energy (in $\mathrm{kJ} \mathrm{mol}^{-1}$ ); 
$\mathrm{R}$ : Gas law constant (in $\mathrm{kJ} \mathrm{mol}^{-1} \mathrm{~K}^{-1}$ );

$\mathrm{T}$ : Absolute temperature (in K).

E was estimated by fitting the linear equation (7):

$$
\operatorname{Ln}\left(k_{h}\right)=-\frac{E}{R} \cdot \frac{1}{T}+\operatorname{Ln} A
$$

\subsection{Results}

\subsubsection{Effects of pre-hydrolysis at $35^{\circ} \mathrm{C}$ on low temperature hydrolysis of}

\section{cellulose}

The hydrolysis rates of cellulose at $10-25^{\circ} \mathrm{C}$ clearly increased after the short prehydrolysis at $35^{\circ} \mathrm{C}$ compared with the measured rates at constant low temperatures, as shown in Fig. 5.1 and Table 5.3. Consequently, the hydrolysis rate constants increased as a result of the pre-hydrolysis at $35^{\circ} \mathrm{C}$, namely from 0.11 to $0.40 \mathrm{~d}^{-1}$ (at $25^{\circ} \mathrm{C}$ ), from 0.03 to $0.11 \mathrm{~d}^{-1}$ (at $15^{\circ} \mathrm{C}$ ), and from $<0.01$ to $0.10 \mathrm{~d}^{-1}$ (at $10^{\circ} \mathrm{C}$ ).

Table 5.3 Hydrolysis rate constant of cellulose and tributyrin with and without the prehydrolysis at $35^{\circ} \mathrm{C}$ (unit: $\mathrm{d}^{-1}$, standard error is in the brackets)

\begin{tabular}{c|cc|cc}
\hline \multirow{2}{*}{$\begin{array}{c}\text { Temperature } \\
\left({ }^{\circ} \mathrm{C}\right)\end{array}$} & $\begin{array}{c}|c| \\
\text { Without } \\
\text { pre- } \\
\text { hydrolysis }\end{array}$ & $\begin{array}{c}\text { With } \\
\text { pre- } \\
\text { hydrolysis }\end{array}$ & pre-hydrolysis & pre-hydrolysis \\
\hline 35 & $0.48(0.02)$ & - & $3.9(0.2)$ & - \\
25 & 0.11 & $0.40(0.01)$ & $3.1(0.2)$ & $2.6(0.1)$ \\
20 & - & - & $2.2(0.1)$ & - \\
15 & 0.03 & 0.11 & $2.0(0.1)$ & $2.9(0.2)$ \\
10 & $<0.01$ & 0.10 & $1.0(0.1)$ & $2.6(0.1)$ \\
\hline
\end{tabular}

- Not measured

When applying pre-hydrolysis at $35^{\circ} \mathrm{C}$, no lag phase occurred after decreasing the 
temperature. For the cellulose hydrolysis without the pre-hydrolysis step, the lag phase was respectively 4 and 6 days at 35 and $25^{\circ} \mathrm{C}$; while later it strongly increased to 18 and 30 days at 15 and $10^{\circ} \mathrm{C}$, respectively. The reason for the long lag phase at low temperatures might be the long time required for sufficient cellulase excretion and coverage of the cellulose surface with cellulase (Sanders et al 2000).

The hydrolysis efficiency of the cellulose with a short pre-hydrolysis at $35^{\circ} \mathrm{C}$ increased from 40 to $62 \%$, and 9.6 to $40 \%$ at 15 and $10^{\circ} \mathrm{C}$, respectively, compared with those without the pre-hydrolysis. A hydrolysis efficiency of $40 \%$ was achieved within 9.1 days at $10^{\circ} \mathrm{C}$, after applying the pre-hydrolysis at $35^{\circ} \mathrm{C}$, while the hydrolysis efficiency at $10^{\circ} \mathrm{C}$ without the pre-hydrolysis step was extremely low even after 62 days and therewith the calculated hydrolysis constant was lower than $0.01 \mathrm{~d}^{-1}$. Decay of biomass in the sample with substrate was probably lower than that in the blank, and might have led to decrease of the percentage hydrolysis after 9.1 days at $10^{\circ} \mathrm{C}$ with pre-hydrolysis (Fig.5.1).

The duration of the pre-hydrolysis at $35^{\circ} \mathrm{C}$ (2.2-3.3 days) prior to low temperature (10$25^{\circ} \mathrm{C}$ ) hydrolysis of cellulose was short compared with the duration of hydrolysis, $44-$ 62 days, at low temperatures $\left(10-25^{\circ} \mathrm{C}\right)$ without the pre-hydrolysis. Hydrolysis efficiencies of $22.0,21.4$, and $13.2 \%$ were achieved within the pre-hydrolysis at $35^{\circ} \mathrm{C}$ before decreasing temperature to 25,15 and $10^{\circ} \mathrm{C}$, respectively.

The major hydrolysis product of cellulose was methane, which accounted for $97-98 \%$ of the hydrolysed COD. The rest was VFA, while the glucose concentration was below the detection limit. The biodegradability of cellulose was $70 \pm 2 \%$ at a constant temperature of $35^{\circ} \mathrm{C}$, and it was $80 \pm 4 \%$ in the test where pre-hydrolysis at $35^{\circ} \mathrm{C}$ was applied. The hydrolysis efficiency of cellulose at low temperatures was calculated based on the biodegradability determined at the prevailing temperature.

\subsubsection{Effects of pre-hydrolysis at $35^{\circ} \mathrm{C}$ on low temperature hydrolysis of}

\section{tributyrin}

\subsubsection{Low temperature hydrolysis $\left(10-15^{\circ} \mathrm{C}\right)$ increased after applying a short pre- hydrolysis at $35^{\circ} \mathrm{C}$}

The hydrolysis rate of tributyrin at $10^{\circ} \mathrm{C}$ after applying a short pre-hydrolysis step at $35^{\circ} \mathrm{C}$ clearly increased compared with the one without the pre-hydrolysis, as shown in Fig. 5.2. It also slightly increased for $15^{\circ} \mathrm{C}$, but was similar for $25^{\circ} \mathrm{C}$. The hydrolysis rate constants at 15 and $10^{\circ} \mathrm{C}$ with the pre-hydrolysis step at $35^{\circ} \mathrm{C}$ were 1.5 and 2.6 times higher as those at 15 and $10^{\circ} \mathrm{C}$ without the pre-hydrolysis (as shown in Table 5.3). The hydrolysis rate after decreasing the temperature from 35 to $25^{\circ} \mathrm{C}$ was similar to that at a constant temperature of $25^{\circ} \mathrm{C}$. 

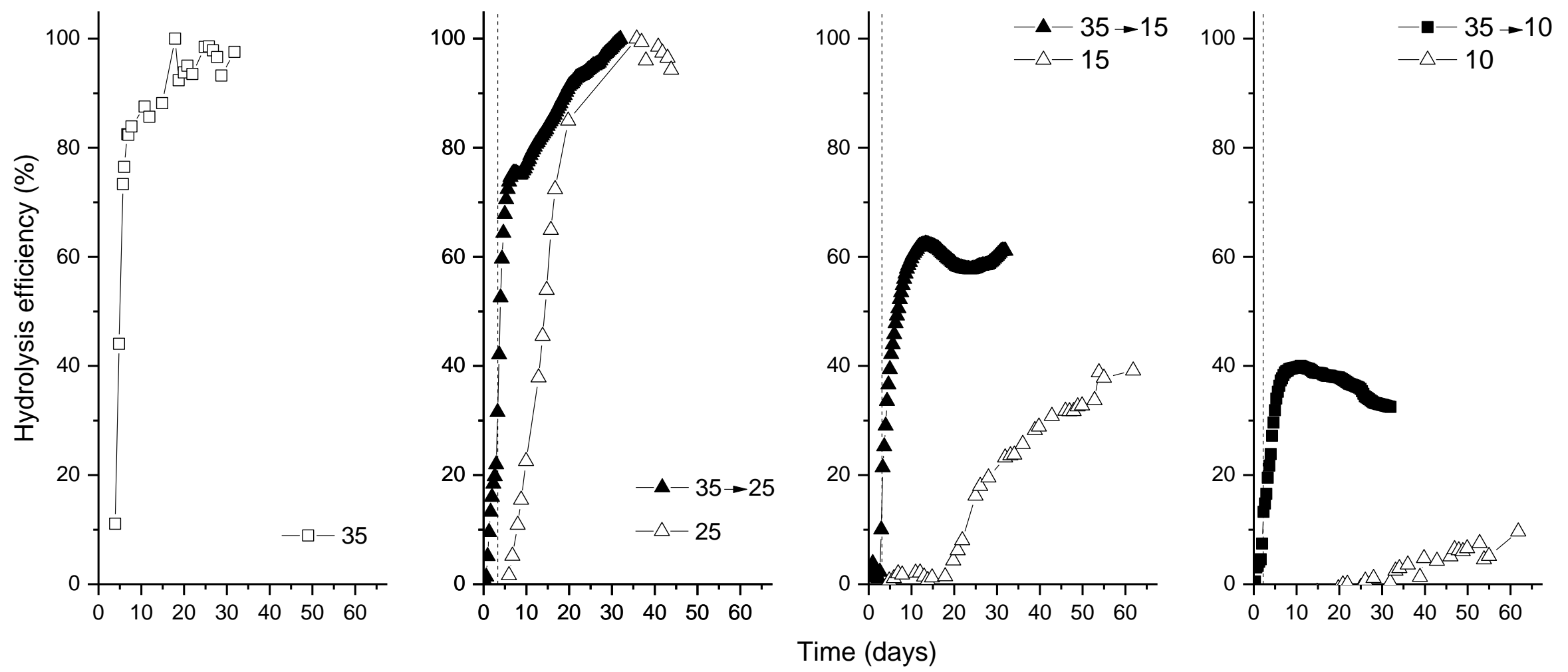

Fig.5.1 Effects of a pre-hydrolysis at $35^{\circ} \mathrm{C}$ on low temperature anaerobic hydrolysis of cellulose COD;

(cellulose had a biodegradability of $70 \pm 2 \%$ at $35^{\circ} \mathrm{C}$ and $80 \pm 4 \%$ with pre-hydrolysis; cellulose hydrolysis (\%) was calculated based on the biodegradability; $35 \rightarrow 25,35 \rightarrow 15$ and $35 \rightarrow 10$ : temperature was decreased from 35 to 25,15 and $10^{\circ} \mathrm{C}$ after $3.3,3.1$ and 2.2 days) 

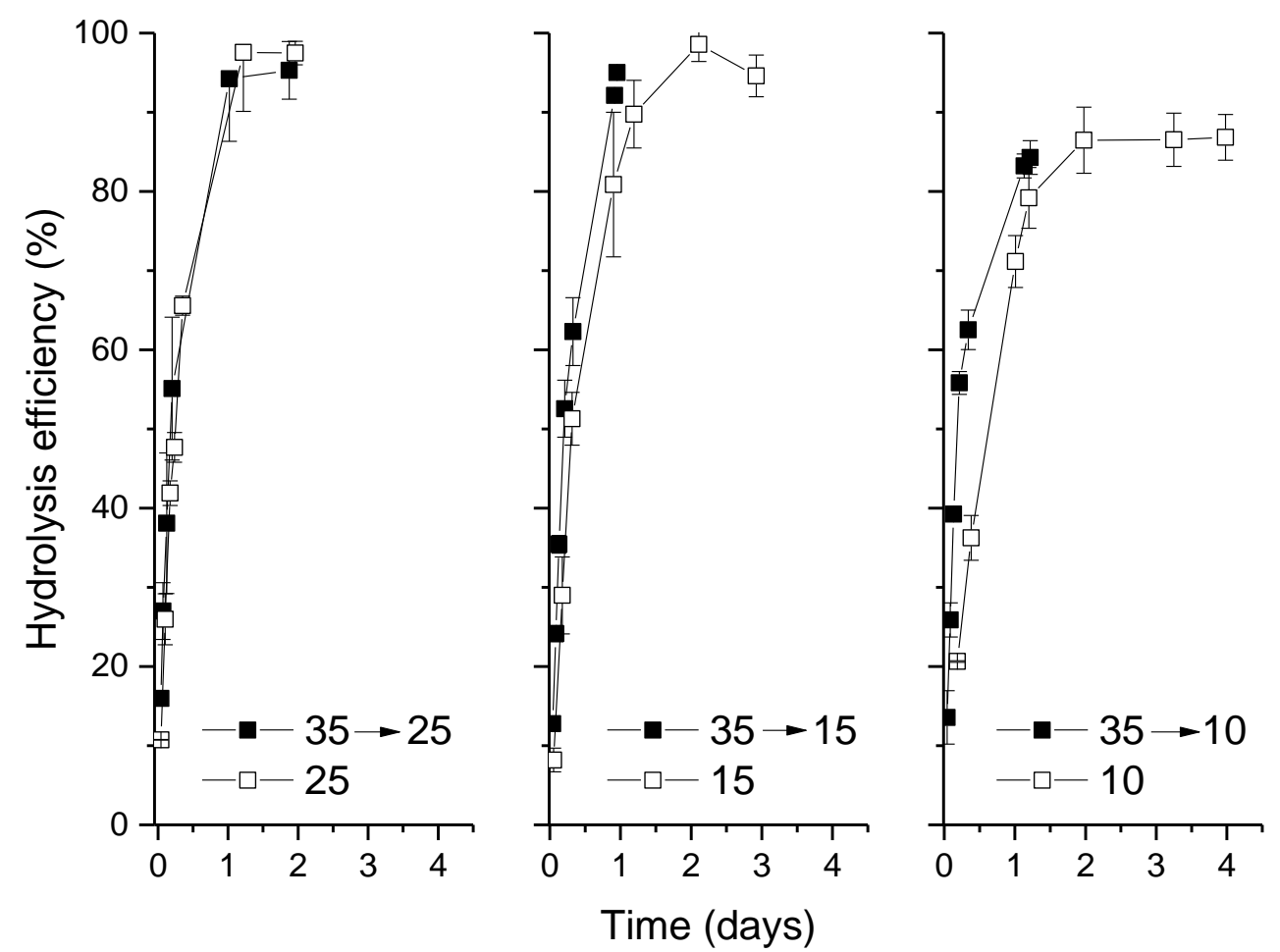

Fig.5.2 Effects of a pre-hydrolysis at $35^{\circ} \mathrm{C}$ on low temperature anaerobic hydrolysis of tributyrin $\mathrm{COD}(35 \rightarrow 25,35 \rightarrow 15$ and $35 \rightarrow 10$ : temperature was decreased from 35 to 25,15 and $10^{\circ} \mathrm{C}$ after 0.08 days)

No lag phase was found during the hydrolysis of tributyin at any temperature. The low temperature $\left(10-25^{\circ} \mathrm{C}\right)$ hydrolysis efficiency was similar at applying batch digestion with and without pre-hydrolysis at $35^{\circ} \mathrm{C}$. The hydrolysis efficiency was nearly $100 \%$ at $15-35^{\circ} \mathrm{C}$ and $87 \%$ at $10^{\circ} \mathrm{C}$. The duration of the pre-hydrolysis at $35^{\circ} \mathrm{C}(0.08$ days $)$ was short compared with the duration of the low temperature hydrolysis $\left(10-25^{\circ} \mathrm{C}\right)$ without the pre-hydrolysis step (3.0-4.0 days). A hydrolysis efficiency of $24-27 \%$ was achieved during the pre-hydrolysis at $35^{\circ} \mathrm{C}$ before subsequently decreasing the temperature.

\subsubsection{Hydrolysis of tributyrin at constant low temperatures $\left(10-35^{\circ} \mathrm{C}\right)$}

The hydrolysis products of tributyrin in time at constant temperatures are shown in Fig.5.3. The biodegradability of tributyrin varied between 97 and $100 \%$ at $15-35^{\circ} \mathrm{C}$. No lag phase was found in the tributyrin hydrolysis. The hydrolysis products of tributyrin consisted of butyrate, accounting for $56-70 \%$ at most, and the rest was propionate while no acetate was present (not shown in Fig.5.3). The maximum VFA production accounted for $74-82 \%$ of the tributyrin COD for all temperatures. The final $\mathrm{pH}$ was 6.9 to 7.2 that did not lead to inhibiting hydrolysis and methanogenesis (Veeken and Hamelers, 1999). The accumulation of VFA was likely due to the absence of butyrate consuming bacteria in the inoculum. The total methane production decreased from 40 to $4 \%$ as temperature decreased from 35 to $10^{\circ} \mathrm{C}$. Glycerol accounted for maximal $7 \%$ of the initial triburyrin COD concentration and was fully consumed within 2 - 3 days at $15-35^{\circ} \mathrm{C}$; at $10^{\circ} \mathrm{C}, 4 \%$ was left after 4 days batch digestion. 

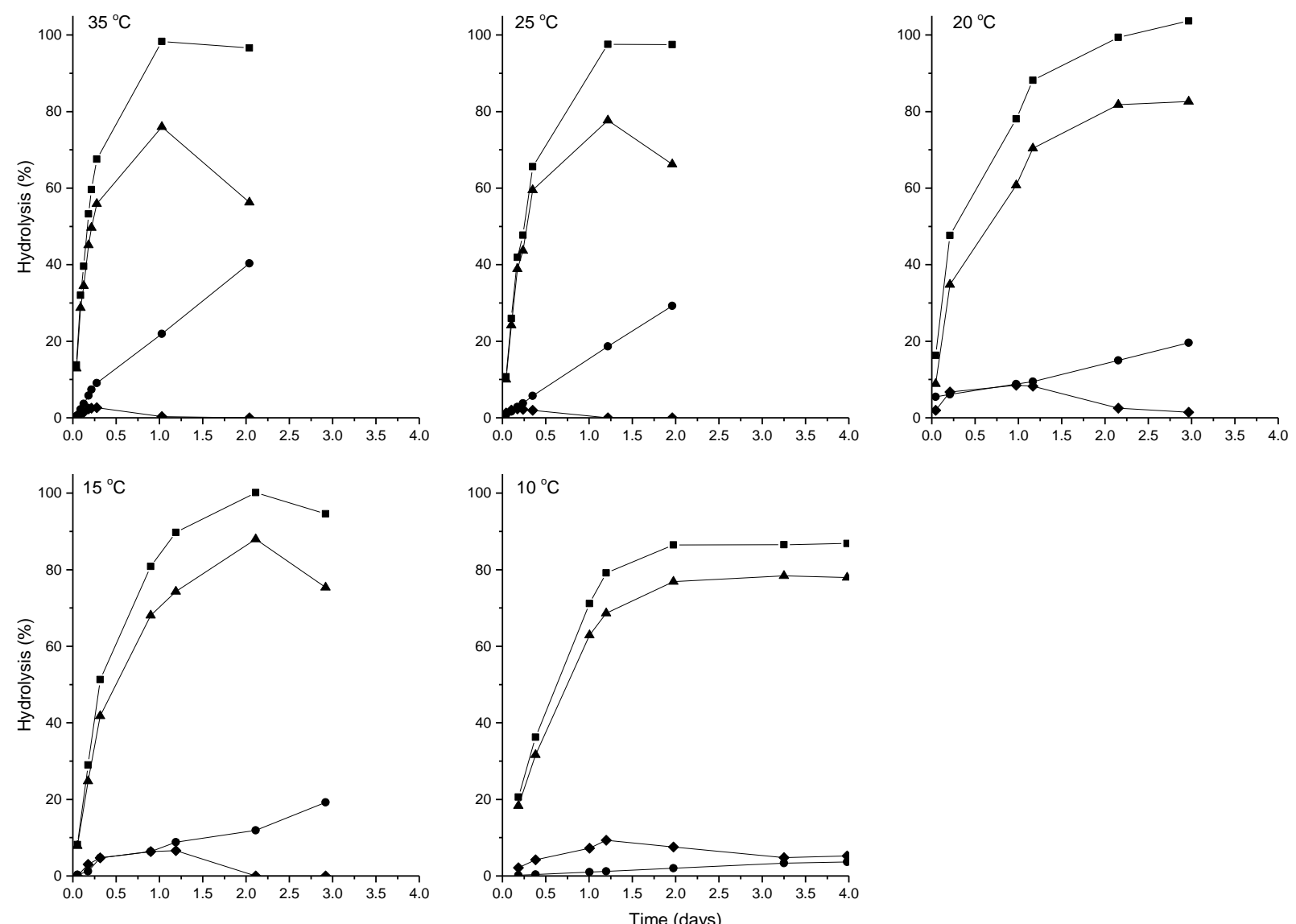

Fig.5.3 Hydrolysis percentage of tributyrin at constant temperatures as a function of time (biodegradability of triburyrin varies between 97 and $100 \%$ at 15 $35^{\circ} \mathrm{C}$; hydrolysis percentage of tributyrin (\%) was calculated based on the biodegradability of $100 \%$; Total $\Delta$ VFA $\bullet$ Methane Glycerol) 


\subsubsection{Hydrolytic activity of supernatant phase at $10-35^{\circ} \mathrm{C}$}

Hydrolysis tests at $35^{\circ} \mathrm{C}$ were also performed using only the supernatant from the digestate after batch digestion of cellulose and tributyrin at $10-35^{\circ} \mathrm{C}$. These tests give insight in whether excess enzymes were released to the liquid phase, or active enzyme production by the biomass cause the higher hydrolysis rate when pre-hydrolysis at a higher temperature is applied.

The hydrolytic activity of the supernatant collected from $35^{\circ} \mathrm{C}$ digestate, after cellulose hydrolysis, was higher than that of the supernatants collected from the $10-25^{\circ} \mathrm{C}$ "cellulose digestate" (Fig.5.4 and Table 5.4). The hydrolysis rate constant of cellulose determined with the supernatant was similar to that with the digester sludge, while the hydrolytic rate constant for tributyrin in the supernatant was clearly lower than that determined with the digester sludge, as shown in Table 5.4.

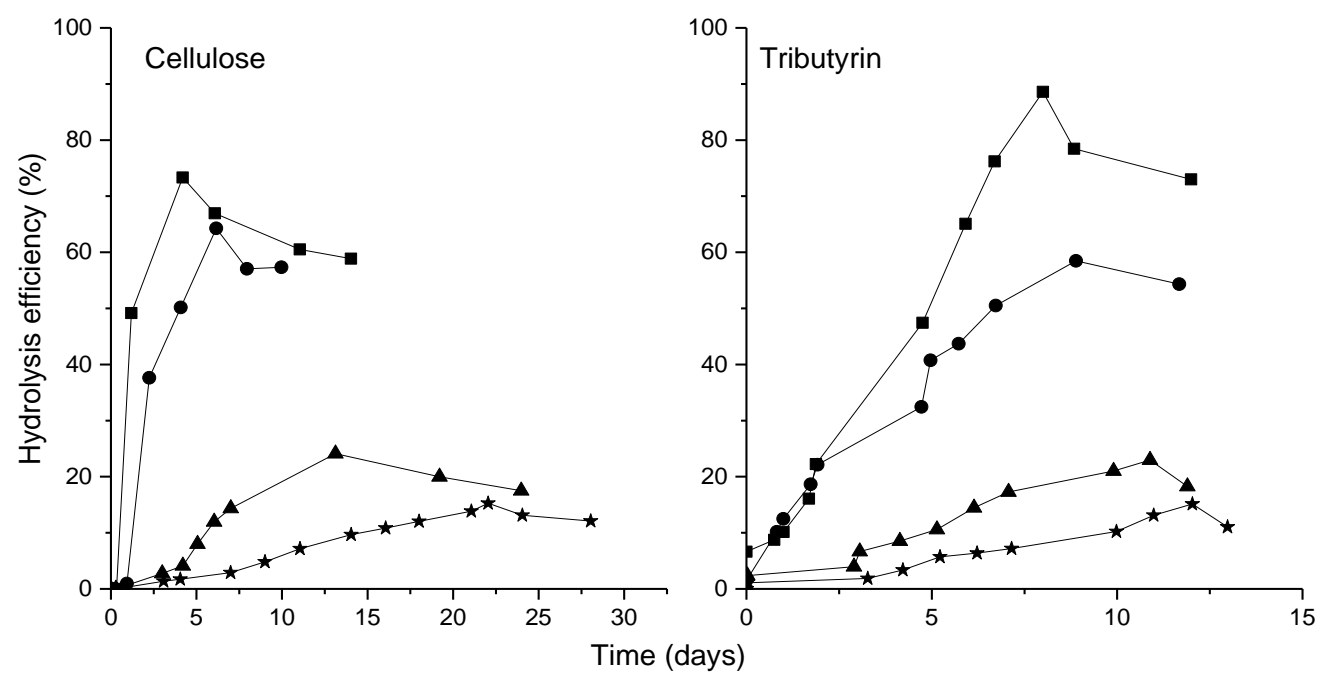

Fig.5.4 Hydrolysis of cellulose and tributyrin using the supernatant at $35^{\circ} \mathrm{C}$

(Supernatant was collected from hydrolysis of cellulose and tributyrin at different temperatures, $\mathbf{\square}: 35 \mathbf{0}: 25 \mathbf{\Delta}: 15 \star: 10)$

The maximum cellulose hydrolysis efficiency, using the supernatants collected from digestate, after cellulose hydrolysis at $35,25,15$ and $10^{\circ} \mathrm{C}$, decreased with temperature from 73 to $51 \%$. No lag phase was found during any of the supernatant hydrolysis tests for cellulose. The maximum tributyrin hydrolysis efficiency also decreased with temperature, viz. from 89 to $42 \%$, when using the supernatants collected from digestate, after tributyrin hydrolysis at $35,25,15$ and $10^{\circ} \mathrm{C}$. No lag phase was found for the supernatant collected at 25 and $35^{\circ} \mathrm{C}$, but a lag phase of 2.9 and 3.3 days was found for those collected at 15 and $10^{\circ} \mathrm{C}$

\subsubsection{Discussion}

The hydrolysis rate constants of cellulose and tributyrin, when constant temperature 
Table 5.4 Hydrolysis rate constant of cellulose and tributyrin using the digester sludge at 10$35^{\circ} \mathrm{C}$ and using the supernatant (unit: $\mathrm{d}^{-1}$, standard error is in the brackets, the supernatant experiments were performed at $35^{\circ} \mathrm{C}$ )

\begin{tabular}{ccccc}
\hline $\begin{array}{c}\text { Temperature } \\
\left({ }^{\circ} \mathrm{C}\right)\end{array}$ & $\begin{array}{c}\text { Using the } \\
\text { digester sludge }\end{array}$ & $\begin{array}{c}\text { Using the } \\
\text { supernatant }\end{array}$ & $\begin{array}{c}\text { Using the } \\
\text { digester sludge }\end{array}$ & $\begin{array}{c}\text { Using the } \\
\text { supernatant }\end{array}$ \\
\hline 35 & $0.46(0.02)$ & $0.31(0.02)$ & $4.0(0.1)$ & 0.21 \\
25 & $0.20(0.01)$ & $0.18(0.01)$ & $2.1(0.1)$ & 0.10 \\
15 & 0.03 & 0.02 & $1.4(0.1)$ & 0.02 \\
10 & 0.01 & 0.01 & $1.1(0.1)$ & 0.01 \\
\hline
\end{tabular}

was applied, decreased with temperature for the range of 35 to $10^{\circ} \mathrm{C}$. The same trend was found in other researches (Pavlostathis \& Giraldo-Gomez, 1991b). In that study, the hydrolysis rate constants of the six selected components of biowaste decreased as temperature decreased from 40 to $20^{\circ} \mathrm{C}$ (Veeken \& Hamelers, 1999). They also found that the hydrolysis efficiency of cellulose decreased strongly when temperature decreased from 15 to $10^{\circ} \mathrm{C}$. Biodegradability of the cellulose at $35^{\circ} \mathrm{C}$ was used for the calculation of hydrolysis rate constants at low temperatures. Experiments at low temperatures are inaccurate and inconvenient due to the slow rates. Similarly, Cysneiros et al. (2011) reported that the total volatile solids degradation decreased from 53 to $19 \%$ as temperature dropped from 37 to $10^{\circ} \mathrm{C}$ when studying effects of temperature on the trophic stages of perennial rye grass anaerobic digestion. Bohn et al. (2007) found that anaerobic hydrolysis of crop residues decreased from 345 to $46 \mathrm{ml} \mathrm{CH}_{4} \mathrm{~g}^{-1} \mathrm{VS}^{-1}$ as temperature decreased from 33 to $18^{\circ} \mathrm{C}$.

Effects of temperature on the hydrolysis rate constant can be described by the Arrhenius equation for enzyme catalysis when the enzyme concentration is not the limiting factor. The activation energy of tributyrin hydrolysis in the here presented study was calculated to be $36 \mathrm{~kJ} \mathrm{~mol}^{-1}$ (not shown in the results section). The low value is typical for enzyme kinetics reaction $\left(20-80 \mathrm{~kJ} \mathrm{~mol}^{-1}\right)$ (Levenspiel, 2013). As low temperatures led to limiting the cellulose hydrolysis rate, therewith, the activation energy of cellulose hydrolysis was not calculated.

Within the present work low temperature $\left(10-25^{\circ} \mathrm{C}\right)$ hydrolysis of cellulose and tributyrin was studied with the pre-hydrolysis at $35^{\circ} \mathrm{C}$. The results showed that the hydrolysis rate constants with the pre-hydrolysis at $35^{\circ} \mathrm{C}$ remained relatively high when decreasing the temperature to 25,15 and $10^{\circ} \mathrm{C}$. Hydrolytic enzyme concentrations, enzyme activity and adherence of anaerobic hydrolytic bacteria to the substrate play an important role in hydrolysis (Azman et al., 2015; Goel et al., 1998). One or several of 
these factors might limit hydrolysis at low temperatures. It was reported that the cellulase produced by anaerobic bacteria showed a relatively low concentration (filter paper units(FPU) $\mathrm{L}^{-1}$ culture broth ) and a low productivity (FPU $\mathrm{L}^{-1} \mathrm{~h}^{-1}$ ), even under suitable conditions of anaerobic digestion ( $\mathrm{pH} 7$ and temperature $37^{\circ} \mathrm{C}$ ) (Adney et al., 1991). Sanders et al (2000) reported an increased lag phase when hydrolysing small starch particles from potatoes in comparison to large starch particles. Latter was partly ascribed to the relatively large substrate surface of the small particles, and partly to the low numbers of hydrolytic enzymes present at the start of the experiment to cover the substrate surface. The increased lag phase at decreased temperature as found in the present research for cellulose hydrolysis indicated a limited cellulase production rate at lower temperatures.

The presented results clearly show an increased hydrolysis rate constant at low temperatures when pre-hydrolysis at $35^{\circ} \mathrm{C}$ is applied. It is likely that at low temperatures (lower than $20^{\circ} \mathrm{C}$ ), hydrolytic enzyme concentration is low compared with that at $35^{\circ} \mathrm{C}$ (as shown in Fig.5.5). The results of the present research indicate that for low temperature hydrolysis with the pre-hydrolysis at $35^{\circ} \mathrm{C}$, the hydrolytic enzymes produced at the start temperature of $35^{\circ} \mathrm{C}$ were still active when decreasing the temperature. This relatively high number of enzymes resulted in high hydrolysis rate compared with those starting at low temperatures. Effects of a short pre-hydrolysis at $35^{\circ} \mathrm{C}$ on low temperature hydrolysis are for the first time studied in the present work. As most literature describes hydrolysis of anaerobic digestion at constant mesophilic or thermophilic conditions (Speece, 2008), no results can be used to compare with low temperature hydrolysis with a pre-hydrolysis at $35^{\circ} \mathrm{C}$.

The positive effect of pre-hydrolysis at $35^{\circ} \mathrm{C}$ on low temperature cellulose hydrolysis was greater than that on tributyrin hydrolysis. This difference was probably due to the difference in substrate type; tributyrin is soluble and cellulose is particulate. Sanders (2002) reported an increasing hydrolysis rate constant of dissolved polymer substrates with an increasing biomass concentration, which indicated an infinite surface area for dissolved substrates. The results in this study show a substantial lower hydrolysis rate constant of tributyrin when using digestate supernatant as compared to using digester sludge. The latter could be attributed to the large available substrate surface during hydrolysis of tributyrin when using digester sludge, which resulted in a low number of excess enzymes in the supernatant. The low number of excess enzymes in the supernatant also explained that the positive effect of pre-hydrolysis for tributyrin was only clear for lower temperatures $\left(10-15^{\circ} \mathrm{C}\right)$. In contrast, particulate cellulose has a limited surface and, therefore, excess cellulases are excreted to the supernatant during digestion at $35^{\circ} \mathrm{C}$. The hydrolytic enzyme activity using the supernatant for cellulose hydrolysis at $35^{\circ} \mathrm{C}$ was close to the one using digester sludge. These excess cellulases could accelerate the hydrolysis at lower temperatures.

In principle, the effect of a short pre-hydrolysis at $35^{\circ} \mathrm{C}$ on low temperature anaerobic 

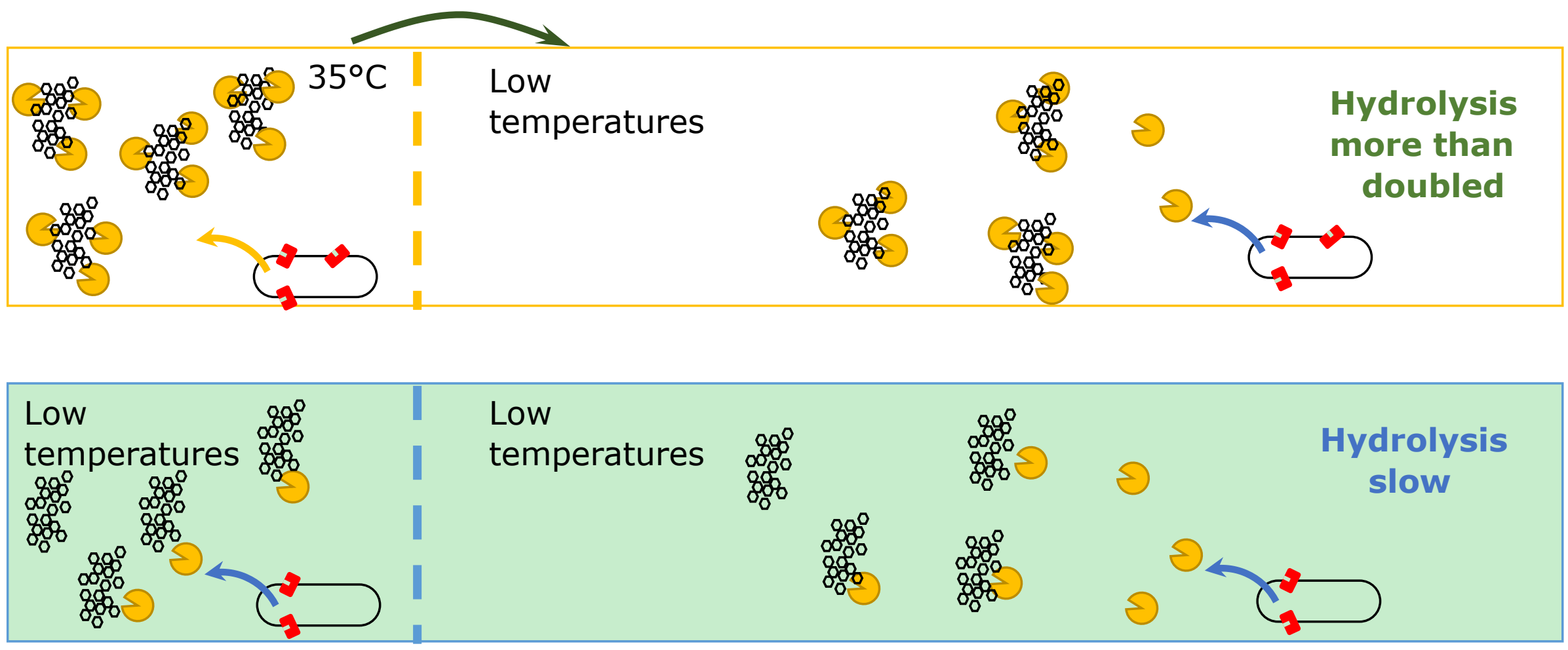

Start-up

$$
\begin{array}{cc}
88^{\circ} \\
80^{\circ}
\end{array} \quad \begin{gathered}
\text { Particulate } \\
\text { silhstrate }
\end{gathered} \begin{gathered}
\text { Released } \\
\text { hydrolytic enzyme }
\end{gathered}
$$

Anaerobic bacteria

Enzyme in the cell membrane

Fig.5.5 Hypothesis on the increased hydrolysis rate constant at low temperatures with a pre-hydrolysis at $35^{\circ} \mathrm{C}$ 
hydrolysis is positive as higher hydrolysis efficiency can be achieved at a certain HRT (SRT). A direct positive effect could be achieved when considering anaerobic digestion of i.e. manure followed by a long term storage at ambient temperature (determined by use of manure as a fertiliser during the crop growing season). The enzymes excreted at high temperature will continue working during the ambient temperature storage. The potential extra conversion could lead to reduced HRT in the digester provided that biogas and digestate storage are integrated to prevent methane emission (Zeeman, 1994).

For a UASB-digester system treating domestic sewage, however, a negative effect is foreseen. In the UASB-digester system, the UASB reactor and the digester is operatedat low temperatures and at $35^{\circ} \mathrm{C}$, respectively (Zhang et al. 2012). The recirculated digester sludge of $35^{\circ} \mathrm{C}$ will elevate the hydrolysis efficiency of organic particulates in the low temperature UASB reactor and therewith the required acidogenic, acetogenic and methanogenic activity. Zhang et al. (2016) showed, despite this increased $\mathrm{COD}_{\text {sol }}$ production in the UASB, a good performance can be achieved with the UASB-digester at temperatures in the UASB as low as $12.5^{\circ} \mathrm{C}$. The energy consumption of a UASBdigester system is limited as only the UASB-sludge, ca. $10-15 \%$ of the total wastewater volume, is recirculated over a heated sludge digester (Zhang et al. (2012)) and Zhang et al. (2016). The UASB-digester can therefore be more energy efficient than i.e. an activated sludge system.

\subsection{Conclusions}

Low temperature $\left(10-25^{\circ} \mathrm{C}\right)$ anaerobic hydrolysis rate can be increased by applying a short pre-hydrolysis at $35^{\circ} \mathrm{C}$ :

- With a pre-hydrolysis at $35^{\circ} \mathrm{C}$, the hydrolysis rate constants of cellulose increased from 0.11 to 0.40 , from 0.03 to 0.11 and from $<0.01$ to $0.10 \mathrm{~d}^{-1}$ at 25,15 and $10^{\circ} \mathrm{C}$, respectively; Similarly, the hydrolysis rate constants of tributyrin at 15 and $10^{\circ} \mathrm{C}$ with the pre-hydrolysis at $35^{\circ} \mathrm{C}$ were 1.5 and 2.6 times higher as those at 15 and $10^{\circ} \mathrm{C}$, respectively, without the pre-hydrolysis.

- No lag phase in hydrolysis was found when decreasing temperature after the prehydrolysis at $35^{\circ} \mathrm{C}$; while the lag phase without the pre-hydrolysis for the cellulose hydrolysis increased from 4 - 30 days with a temperature decrease from 35 to $10^{\circ} \mathrm{C}$. The tributyrin hydrolysis showed no lag phase at any temperature.

- The hydrolysis efficiency of the cellulose with the pre-hydrolysis at $35^{\circ} \mathrm{C}$ increased from 40 to $62 \%$, and 9.6 to $40 \%$ at 15 and $10^{\circ} \mathrm{C}$, respectively, compared with those at low temperatures $\left(10-15^{\circ} \mathrm{C}\right)$ without the pre-hydrolysis; the hydrolysis efficiency of tributyrin was nearly $100 \%$ at $15-35^{\circ} \mathrm{C}$ and $87 \%$ at $10^{\circ} \mathrm{C}$, which was similar to those with the pre-hydrolysis at $35^{\circ} \mathrm{C}$.

- The hydrolytic activity of the supernatant collected after batch digestion of cellulose and tributyrin at $35^{\circ} \mathrm{C}$ was higher than that collected at low temperatures. 


\section{Acknowledgements}

The authors thank STOWA (Foundation for Applied Water Research), Paques BV, RVO (Netherlands Enterprise Agency), Hoogheemraadschap de Stichtse Rijnlanden, Hoogheemraadschap van Rijnland, Waterschapsbedrijf Limburg, Waterschap Drents Overijsselse Delta, Waterschap Rivierenland en Waternet for supporting this research. 
6 Effects of temperature and temperature shocks on specific methanogenic activity and affinity for acetate of sludge exposed to varying temperature conditions $\left(10-35^{\circ} \mathrm{C}\right)$

Lei Zhang, Tim L.G. Hendrickx, Huub Rijnaarts, Grietje Zeeman This chapter is to be submitted 


\begin{abstract}
Digester sludge of a UASB $\left(12.5^{\circ} \mathrm{C}\right)$-sludge digester $\left(35^{\circ} \mathrm{C}\right)$ was fed with acetate at constant temperatures of $10-35^{\circ} \mathrm{C}$ and at varying temperatures from $35^{\circ} \mathrm{C}$ to 25 , to 15 to $10^{\circ} \mathrm{C}$. Effects of temperature and temperature shocks on specific methanogenic activity (SMA), and affinity of the digester sludge were studied. The results showed that no lag phase in methane production rate occurred when applying the temperature shocks of $35^{\circ} \mathrm{C}$ to 25,15 , and $10^{\circ} \mathrm{C}$. The temperature dependence of the SMA of the digester sludge with the temperature shocks was similar to the one at constant temperatures. The activation energy for the SMA of the digester sludge was $62 \mathrm{~kJ} / \mathrm{mol}$. Acetate affinity of the digester sludge was high at the applied temperatures $\left(10-35^{\circ} \mathrm{C}\right)$.
\end{abstract}




\subsection{Introduction}

Anaerobic treatment of municipal wastewater has three main advantages over treatment using aerobic conventional activated sludge systems: namely the potential low energy consumption due to the absence of aeration, low amounts of excess sludge production reducing costs of sludge processing, and energy recovery from wastewater chemical oxygen demand (COD) in the form of methane (Kassab et al., 2010; Speece, 2008). Generally, anaerobic treatment of municipal wastewater is considered applicable at temperatures between $30-35^{\circ} \mathrm{C}$, i.e. in (sub) tropical regions. In moderate climate areas, municipal wastewater has temperatures between $10-20^{\circ} \mathrm{C}$ posing a limitation to anaerobic treatment. Low temperature leads to a low hydrolysis rate of organic wastewater solids and a low specific methanogenic activity of the anaerobic biomass (Leit Ã£o et al., 2006; Lettinga et al., 2001). A combined UASB-digester process has been proposed to resolve these limitations of low temperature and low COD concentration for anaerobic treatment (Álvarez et al., 2004; Mahmoud, 2008; Mahmoud et al., 2004; Zhang et al., 2013).

In this system, the UASB reactor is operated at the low temperature of the wastewater and at a short hydraulic retention time (HRT). The idea is that the UASB sludge blanket captures the suspended COD from the wastewater without biodegradation, and only converts the soluble influent organics to methane. The formed non-stabilized UASB sludge is fed to the digester operated at $30-35^{\circ} \mathrm{C}$. Here the suspended COD entrapped in the UASB sludge is hydrolyzed and digested yielding methane and stabilized anaerobic sludge. Returning this sludge from the digester to the UASB reactor provides the UASB reactor with active methanogens for converting soluble COD in the UASB reactor. The biogas production of the digester and the UASB reactor can provide the energy needed for heating the digester (Zhang et al., 2012). The above mentioned combined process can only be successful when the methanogens fed back from the warm digester sludge to the cold UASB reactor maintain adequate methanogenic activity and substrate affinity for converting the soluble wastewater COD in the UASB reactor into methane.

The recirculated digester sludge and the UASB sludge are subjected to sudden changes in temperature upon recirculating the sludge. Temperature of the UASB sludge recirculated to the digester suddenly increases; temperature of the recirculated digester sludge suddenly decreases when entering the UASB reactor. Effects of temperature change on anaerobic processes were investigated in various studies. Biogas production under seasonal temperature change between winter $\left(14-25^{\circ} \mathrm{C}\right)$ and summer $\left(24-35^{\circ} \mathrm{C}\right)$ in Brazil was studied when applying a pilot scale anaerobic digestion of cattle manure (Resende et al., 2015). No difference in average methane yield was found with the gradually changed temperature. Biogas production rate under daily downward and daily upward temperature fluctuation was studied when applying anaerobic digestion of cow manure at 50 and $60^{\circ} \mathrm{C}$ at an HRT of $20 \mathrm{ds}$ (El-Mashad et al., 2004). Biogas production rate at $50^{\circ} \mathrm{C}$ was higher than at $60^{\circ} \mathrm{C}$ when a temperature change imposed $10^{\circ} \mathrm{C}$ reduced 
for $10 \mathrm{~h}$ and $10^{\circ} \mathrm{C}$ increased for $5 \mathrm{~h}$ respectively. Lau and Fang (1997) reported that suddenly applied changes in temperature to thermophilic granules from 55 to $37^{\circ} \mathrm{C}$ resulted in poor COD removal, granule disintegration and biomass washout. Kettunen and Rintala (1997b) reported for mesophilic digester sludge, a sudden decrease in temperature from 35 to $15^{\circ} \mathrm{C}$ resulted in a one-day lag-phase before acetate consumption recovered. Gao et al. (2011) found that a decreased temperature by 5 and $10^{\circ} \mathrm{C}$ starting at $37^{\circ} \mathrm{C}$ could be tolerated for a submerged anaerobic membrane bioreactor (SAMBR); the same changes starting at $45^{\circ} \mathrm{C}$ led to a significant disturbance of the performance. However, effects of a sudden decrease in temperature on methanogenic activity of sludge from a UASB-digester recirculation system have not been reported before.

High affinity of the sludge of the UASB-digester process for soluble COD and especially acetate, is important when treating municipal wastewater with relatively low COD concentrations at high loading rates. The affinity can be presented by the halfsaturation velocity constant $\left(K_{s}\right)$ in the Monod equation (Arnaldos et al., 2015). Monod equation can be expressed in terms of substrate utilization rates (Duran \& Tepe, 2004; Pavlostathis \& Giraldo-Gomez, 1991a). Varying conditions in $\mathrm{K}_{\mathrm{s}}$ quantification experiments are substrate concentration, microbial culture, temperature and experimental set-up (batch or continuous experiment). Generally, the value of Ks of anaerobic sludge increases (i.e. the affinity decreases) when temperature decreases, as shown by Lokshina et al. (2001) and Banik et al. (1998) for treating municipal landfill leachate and synthetic municipal wastewater. Substrate affinity and mass transfer limitations may additionally impact methanogenesis and its dependence on temperature (Speece, 2008). However, the effects of low temperature on the affinity of the sludge in a UASB-digester process have not yet been studied.

In a UASB-digester system, the sludge is continuously exposed to changing temperature, as the sludge is recirculated from low temperature UASB reactor to the warm digester, and then returned again. The sludge recirculation between the reactors at different temperatures may have a positive effect on adaptability of the sludge to a sudden temperature change. In the study presented here, we determined the effects of an immediate temperature drop from $35^{\circ} \mathrm{C}$ to 25,15 or $10^{\circ} \mathrm{C}$ on the methanogenic activity, and the effects of temperature $\left(10-35^{\circ} \mathrm{C}\right)$ on affinity constant for acetate using the digester sludge from a UASB-digester process. The results are discussed in relation to the optimization of the UASB-digester for treating low temperature $\left(10-20^{\circ} \mathrm{C}\right)$ municipal wastewater.

\subsection{Materials and methods}

\subsubsection{Source of inoculum}

The digester sludge used as inoculum in the batch experiments was collected from a digester operated at $35 \pm 1{ }^{\circ} \mathrm{C}$ in a pilot-scale combined UASB-digester process. The 
influent and internal UASB temperature were kept at $12.5 \pm 1^{\circ} \mathrm{C}$ at the time of sampling. Domestic wastewater, operations and design of the system were similar as described by Zhang et al. (2013), except for the height of the UASB reactor which was increased here to $3.0 \mathrm{~m}$. The influent flow rate and the sludge recirculation rate were $500 \mathrm{~L} / \mathrm{d}$ and 64-80 L/d, respectively. The UASB-digester process had been operating for municipal wastewater treatment for 3 years, and temperature in the UASB reactor was between $10-20^{\circ} \mathrm{C}$.

\subsubsection{Affinity of the digester sludge at $10-35^{\circ} \mathrm{C}$}

The digester sludge was settled for 1 day in a cabinet at $35^{\circ} \mathrm{C}$ after sampling. The settled sludge of $150 \mathrm{ml}$ and $50 \mathrm{ml}$ supernatant was put in a serum bottle of $300 \mathrm{ml}$ with a sampling port. $0.5 \mathrm{ml}$ of $100 \mathrm{~g} / \mathrm{L}$ sodium acetate solution was added as substrate in the serum bottle. The initial acetate concentration was $250 \mathrm{mg}$ COD/L. Nitrogen gas was used to flush the solution in the serum bottle to ensure anaerobic condition. Oxi-top (OC 110, Germany) was connected with the serum bottle to automatically read the pressure of the headspace. Each sample was executed in triplicate and placed in the shakers with $120 \mathrm{rpm}$ at $10,15,25$ and $35^{\circ} \mathrm{C}$.

\subsubsection{Effects of cold temperature shock on SMA}

For cold temperature shock experiments, the digester sludge samples were prepared in the same way as in the affinity experiments, expect for the addition of sodium acetate solution which was $1 \mathrm{ml}$. The experimental bottles in triplicates were placed in shakers at $120 \mathrm{rpm}$ at $35^{\circ} \mathrm{C}$ for 1 hour. Then, the temperature of the sludge samples was lowered to 25,15 or $10^{\circ} \mathrm{C}$ within 15 minutes by placing the bottles in an ice water bath. Additional samples were used as a control for monitoring temperature using a thermometer. The samples were returned to the shakers at 25,15 and $10^{\circ} \mathrm{C}$ after the temperature of the controls dropped to the low temperatures $\left(10-25^{\circ} \mathrm{C}\right)$.

\subsubsection{Activity monitoring}

Gas samples $(2 \mathrm{ml})$ were collected from the sludge sample headspace to measure methane and carbon dioxide composition using gas chromatography (Interscience GC 8000 series) equipped with a thermal conductivity detector and two columns (Molsieve $5 \mathrm{~A} 50 \mathrm{~m} \times 0.53 \mathrm{~mm}$ for nitrogen and methane and Porabond Q $50 \mathrm{~m} \times 0.53 \mathrm{~mm}$ for $\mathrm{CO}_{2}$ ). Temperatures of injector, detector and oven were 110,99 and $50^{\circ} \mathrm{C}$ respectively.

Acetate concentration in a liquid sample $(1 \mathrm{ml})$ was measured after centrifuging with a Thermo Electron IEC Micromax centrifuge (with rotor Cat. No. 3590, USA) at 10000 rpm for 5 mins and then by preparing samples with formic acid (1.5\% of sample) and analysis was done by GC (HP $5890 \mathrm{GC}$; glass column of $2 \mathrm{~m} \times 6 \mathrm{~mm} \times 2 \mathrm{~mm}$ packed with 10\% Fluorad 431 on Supelco-port 100-120 mesh) with an oven temperature of 130 ${ }^{\circ} \mathrm{C}$, and nitrogen saturated with formic acid as the carrier gas applied at a flow of 40 
$\mathrm{ml} / \mathrm{min}$. The injector temperature was $200{ }^{\circ} \mathrm{C}$ and the flame ionization detector at 280

${ }^{\circ} \mathrm{C}$. The sample size was $1 \mu \mathrm{L}$.

Pressure of the sludge sample headspace was measured by a hand-held digital pressure meter (GMH 3150, Germany) with a needle (the precision was up to mbar). The volatile suspended solids (VSS) concentration of the digester sludge was measured according to American Standards (APHA 2005).

VFA measurements in the affinity tests were taken one time per $0.5,1,2$ and $3 \mathrm{~h}$ at 35 , 25,15 and $10^{\circ} \mathrm{C}$ until the substrate was completely consumed. The gas composition was measured every 2 hours.

\subsubsection{Data interpretation and calculations}

Acetate utilization rate (A) of the digester sludge in the test for determination of affinity constant was calculated by equation (1),

$$
\mathrm{A}=\mathrm{dC}_{\text {acetate }} / \mathrm{dt} \times 1 / \mathrm{VSS}
$$

Where:

A: acetate utilization rate (g COD/(gVSS d));

$\mathrm{C}_{\text {acetate: }}$ the amount of acetate ( $\mathrm{g}$ COD);

T: time (d) and VSS is the amount of the digester sludge ( $\mathrm{g}$ ).

SMA (unit: $\mathrm{g} \mathrm{CH}_{4} \mathrm{COD} /(\mathrm{g} \mathrm{VSS} \mathrm{d})$ ) of the digester sludge was calculated from the linear part of a curve describing cumulative methane production in time by equation (2). Based on preliminary tests, the applied initial acetate concentration did not influence SMA. Therewith, SMA was calculated in temperature shock experiments and affinity tests.

$$
\mathrm{SMA}=64 \times \mathrm{dP} / \mathrm{dt} \times \mathrm{V} \times \mathrm{C}_{\text {methane }} /(\mathrm{R} \times \mathrm{T})
$$

Where:

64: a conversion factor for $1 \mathrm{~mol}$ methane to $\mathrm{g}$ methane COD;

$\mathrm{P}$ : pressure of the headspace of the sludge sample $(\mathrm{kPa})$;

$\mathrm{V}$ : the volume of the headspace of the sludge sample (L);

$\mathrm{C}:$ the percentage of methane in biogas (methane/ (methane + carbon dioxide), \%),

$\mathrm{R}$ : ideal gas constant $(\mathrm{R}=8.314 \mathrm{~J} /(\mathrm{mol} \times \mathrm{K}))$, and $\mathrm{T}$ is room temperature $(\mathrm{T}=293 \mathrm{~K})$.

Methane production $\left(\mathrm{CH}_{4}\right)$ was calculated by equation (3):

$$
\mathrm{CH}_{4}=64 \times \mathrm{P} \times \mathrm{C}_{\text {methane }} \times \mathrm{V} /(\mathrm{R} \times \mathrm{T})
$$

The temperature dependence of SMA can be described in Arrhenius equation (Kettunen 
\& Rintala, 1997a). The temperature dependence of methanogenic activity of the digester sludge $(\mathrm{M})$ is shown in equation (4):

Where:

$$
\mathrm{SMA}=\mathrm{M}_{0} \times \exp \left\{-\mathrm{E}_{\mathrm{a}} /(\mathrm{R} \times \mathrm{T})\right\}
$$

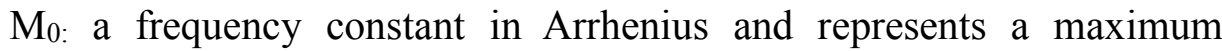
methanogenic activity of the digester sludge in absence of an activation energy $\left(\mathrm{g} \mathrm{CH}_{4} \mathrm{COD} /(\mathrm{g} \mathrm{VSS} \cdot \mathrm{d})\right)$

$\mathrm{E}_{\mathrm{a}}$ : the Activation energy $(\mathrm{kJ} / \mathrm{mol})$.

$E_{a}$ was estimated by fitting the linear equation (5):

$$
\ln (\mathrm{SMA})=-\mathrm{E} / \mathrm{R} \times 1 / \mathrm{T}+\ln \left(\mathrm{M}_{0}\right)
$$

Acetate concentration $(\mathrm{mg} \mathrm{COD} / \mathrm{L})$ and acetate utilization rate were used for Monod equation fit by equation (3),

$$
\mathrm{A}=\mathrm{A}_{\max } \times \mathrm{S} /\left(\mathrm{K}_{\mathrm{s}}+\mathrm{S}\right)
$$

Where:
A: acetate utilization rate $(\mathrm{g} \mathrm{COD} /(\mathrm{gVSS} \cdot \mathrm{d}))$;
$\mathrm{A}_{\max }:$ maximum acetate utilization rate $(\mathrm{g} \mathrm{COD} /(\mathrm{gVSS} \cdot \mathrm{d}))$;
$\mathrm{K}_{\mathrm{s}}$ : half-saturation velocity constant of acetate utilization ( $\left.\mathrm{mg} \mathrm{COD} / \mathrm{L}\right)$;
$\mathrm{S}$ : acetate concentration ( $\mathrm{mg} \mathrm{COD} / \mathrm{L})$.

\subsection{Results}

\subsubsection{Effects of a sudden temperature drop on SMA}

The results in Fig.6.1 show that the methane production of the digester sludge continued without any lag phase, but at a lower rate after an immediate decrease of the temperature from 35 to 25,15 or $10^{\circ} \mathrm{C}$. At each lowered temperature value, the methane production rate of the digester sludge, expressed by slope of the methane production curve, became constant within 12 minutes after changing the temperature.

The temperature dependency of the SMA of the digester sludge was evaluated by applying the Arrhenius model (Fig.6.2). The results show that the temperature dependency of the SMA was similar for the two applied conditions: after applying a temperature shock (Fig.6.1) and at keeping temperature constant (Fig.6.3). The SMA of the digester sludge at $35^{\circ} \mathrm{C}$ was $0.25 \mathrm{~g} \mathrm{CH}_{4} \mathrm{COD} /(\mathrm{gVSS}$ d) as shown in Table 6.1. The apparent activation energy for the SMA of the digester sludge using acetate as substrate was $62 \mathrm{~kJ} / \mathrm{mol}\left(\mathrm{R}^{2}: 0.944\right)$ (Table 6.1). 


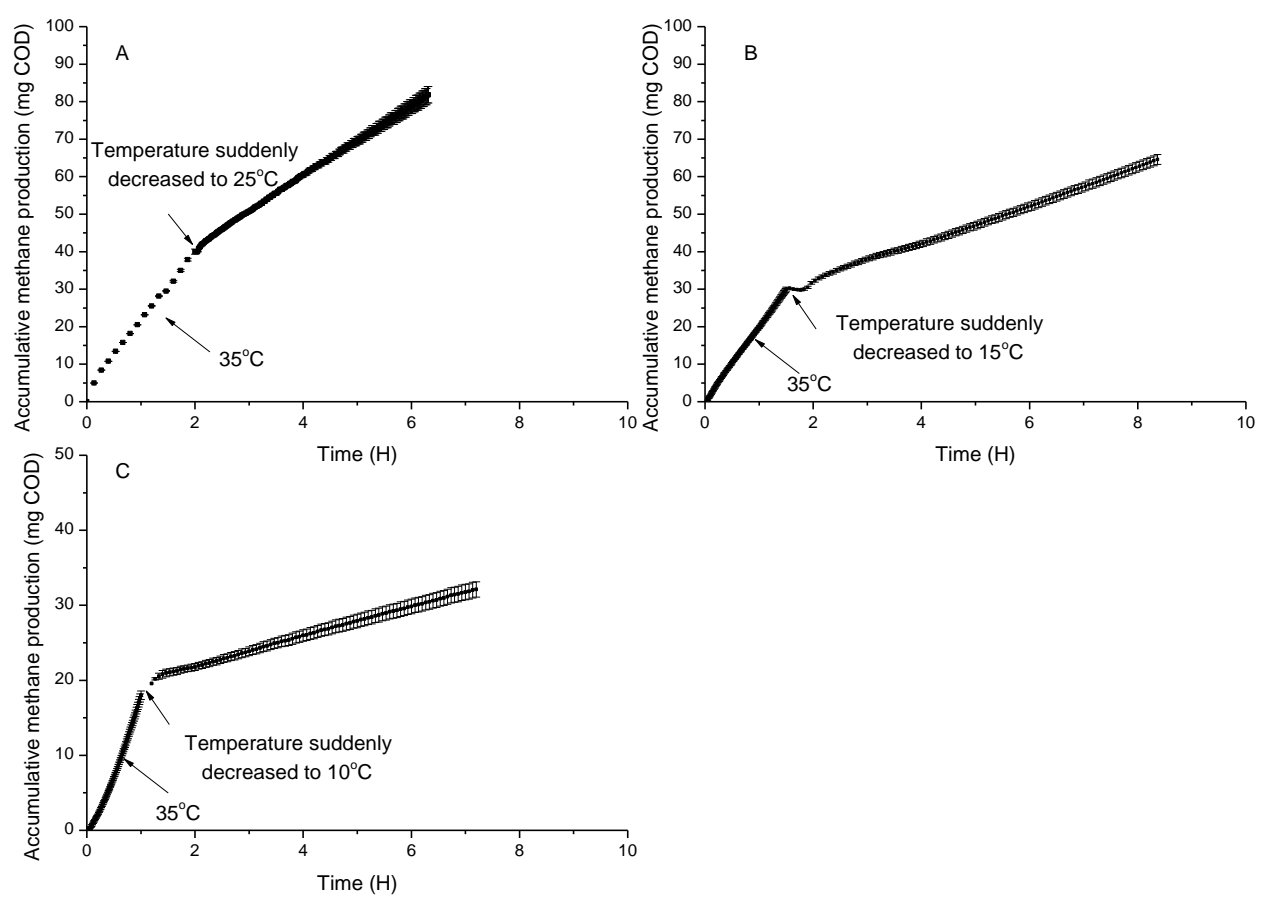

Fig.6.1 Effects of a cold temperature shock on the accumulative methane production during the SMA test of the digester sludge (A, B and C: a sudden temperature decrease from 35 to 25,15 and $10^{\circ} \mathrm{C}$ at $2,1.5$ and $1 \mathrm{~h}$ )

\subsubsection{Effects of low temperature on affinity for acetate utilization}

As shown in Fig.6.3, methane production rate of the digester sludge maintained constant at each temperature until the substrate acetate was completely consumed to below the detection limit of $1 \mathrm{mg} \mathrm{COD} / \mathrm{L}$ at 3.2, 5.4, 9.2 and $22 \mathrm{~h}$ for 35, 25, 15 and $10^{\circ} \mathrm{C}$. The methane production rate decreased to $21 \%$ at $35^{\circ} \mathrm{C}$ afterwards, which was due to the hydrolysis of the digester sludge itself and the same trend occurred at $25^{\circ} \mathrm{C}$. The methane production rate at $25^{\circ} \mathrm{C}$ after the acetate was fully consumed was $45 \%$ of the one at $35^{\circ} \mathrm{C}$ due to the decreased temperature. The methane production rate clearly stopped as acetate was fully consumed at 15 and $10^{\circ} \mathrm{C}$.

The results in Fig.6.3 showed that the acetate utilization rate of the digester sludge maintained high at a low acetate concentration for each temperature $(35,25,15$ and $10^{\circ} \mathrm{C}$ ). The lowest acetate concentration before the utilization rate decreased was 3.0, 5.0, 25.1 and $7.9 \mathrm{mg} \mathrm{COD} / \mathrm{L}$ at $35,25,15$ and $10^{\circ} \mathrm{C}$. The acetate utilization rate was $0.197,0.118,0.072$ and $0.030 \mathrm{~g} \mathrm{COD} /(\mathrm{gVSS} \mathrm{d})$ at $35,25,15$ and $10^{\circ} \mathrm{C}$. The low acetate concentration combined with the results of the methane production rate discussed before indicate that the digester sludge has a high affinity for acetate. $\mathrm{K}_{\mathrm{s}}$ for acetate of the digester sludge at $35^{\circ} \mathrm{C}$ was $6.5 \mathrm{mg} \mathrm{COD} / \mathrm{L}$, while $\mathrm{K}_{\mathrm{s}}$ for the other temperatures was Sensing a sudden decrease of the temperature, bacteria can produce cold shock proteins to adapt to a given temperature (Yamanaka, 1999). Cold acclimation proteins were produced to maintain bacterial activity at a 25 to $5^{\circ} \mathrm{C}$ cold shock and a constant growth at $5^{\circ} \mathrm{C}$ (Gumley \& Inniss, 1996). The EF-2 protein (Mbar_A3686) was considered to 
Table 6.1 Lag phase, $\mathrm{E}_{\mathrm{a}}, \mathrm{K}_{\mathrm{s}}$ and SMA of different types of sludge at different temperatures (unit for temperature: ${ }^{\circ} \mathrm{C}$ )

\begin{tabular}{|c|c|c|c|c|c|c|c|c|}
\hline Authors & $\begin{array}{l}\text { Wastewater } \\
\text { /Temperature }\end{array}$ & Reactor & $\begin{array}{l}\text { Temperature } \\
\text { of SMA tests }\end{array}$ & $\begin{array}{l}\text { Sludge } \\
\text { type }\end{array}$ & $\begin{array}{l}\text { Lag } \\
\text { phase } \\
\text { (days) }\end{array}$ & $\begin{array}{c}\mathrm{E}_{\mathrm{a}} \\
(\mathrm{kJ} / \mathrm{mol})\end{array}$ & $\begin{array}{c}\mathrm{SMA}^{\mathrm{a}} / \text { Temperature } \\
\mathrm{g} \mathrm{CH}_{4} \mathrm{COD}(\mathrm{g} \\
\text { VSS d) }\end{array}$ & $\begin{array}{c}\mathrm{K}_{\text {s temperature }} \\
(\mathrm{mg} \\
\mathrm{COD} / \mathrm{L})\end{array}$ \\
\hline $\begin{array}{c}\text { Zhang et al. (this } \\
\text { study) }\end{array}$ & $\begin{array}{c}\text { Domestic sewage } \\
/ 10-12.5\end{array}$ & $\begin{array}{l}\text { UASB- } \\
\text { Digester }\end{array}$ & $10-35$ & Floc & 0 & 62 & $0.25 / 35$ & 6.535 \\
\hline $\begin{array}{l}\text { Kettunen et al. } \\
\text { (1997) }\end{array}$ & Leachate / 23 & UASB & $5-29$ & Floc & $0.4-3$ & 52 & $0.24 / 29$ & $\begin{array}{l}704_{11^{-}} \\
2944_{22}\end{array}$ \\
\hline $\begin{array}{l}\text { (Rebac et al. } \\
(1999 a) \text {; Rebac et } \\
\text { al. (1995)) }\end{array}$ & $\begin{array}{l}\text { VFA mixture/10- } \\
12\end{array}$ & $\begin{array}{c}\text { Expanded } \\
\text { granular sludge } \\
\text { bed (EGSB) }\end{array}$ & $10-30$ & Granular & - & 68 & $2.20 / 30$ & $39^{\mathrm{b}}{ }_{10}$ \\
\hline $\begin{array}{c}\text { Fey and Conrad } \\
\text { (2000) }\end{array}$ & Rice field soil & $\begin{array}{c}\text { Batch } \\
\text { experiments }\end{array}$ & $10-37$ & $\begin{array}{c}\text { Soil } \\
\text { sample }\end{array}$ & 2 & 61 & $0.015^{\mathrm{c} / 37}$ & - \\
\hline $\begin{array}{l}\text { McKeown et al. } \\
\text { (2009) }\end{array}$ & $\begin{array}{l}\text { Synthetic volatile } \\
\text { fatty acid } \\
\text { wastewater / 4-16 }\end{array}$ & $\begin{array}{c}\text { EGSB - } \\
\text { anaerobic filter } \\
(\text { EGSB-AF })\end{array}$ & $4-37$ & Granular & - & 63 & $1.06 / 37$ & - \\
\hline
\end{tabular}

- Not mention; a: the highest SMA in the tested temperatures; b: elaborated in EGSB; c: methane production rate 


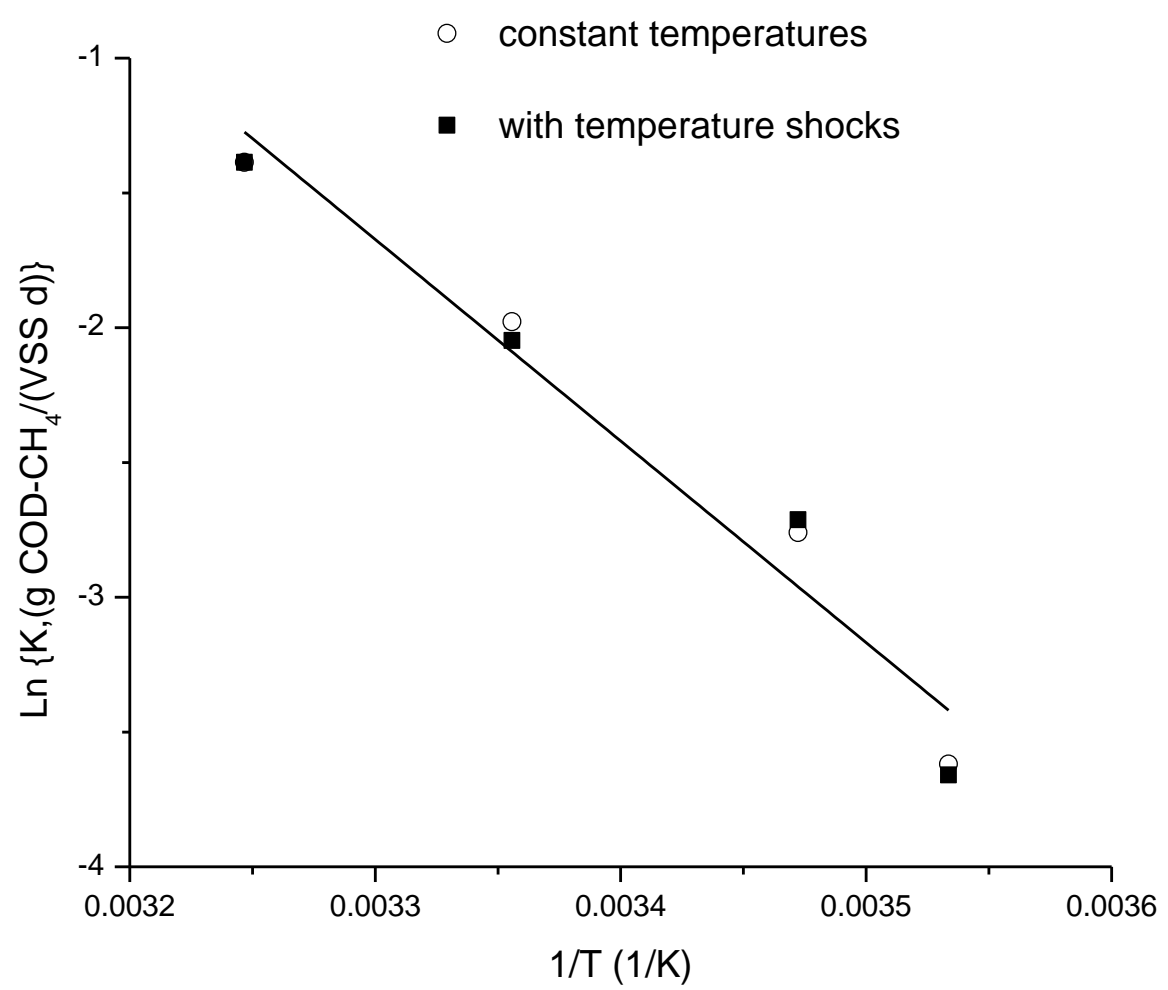

Fig.6.2 Arrhenius model for SMA of the digester sludge using acetate as substrate

play a role in growth of a psychrotolerant methanogens ( $\mathrm{Gu} \&$ Hilser, 2009). This protein was upregulated at $15^{\circ} \mathrm{C}$ compared with $37^{\circ} \mathrm{C}$, not only when applying a temperature shock from 37 to $15^{\circ} \mathrm{C}$, but also in the initial phases of growth at $15^{\circ} \mathrm{C}$ using mesophilic sludge (Gunnigle et al., 2013).

The continuous sludge recirculation of the UASB-digester between low temperature and mesophilic temperature might induce the above mentioned 'cold shock' proteins'. almost 0 . The SMA of the digester sludge during the affinity tests were $0.260,0.143$, 0.065 and $0.028 \mathrm{~g} \mathrm{CH}_{4} \mathrm{COD} /\left(\mathrm{gVSS} \mathrm{d}\right.$ ) for respectively $35,25,15$ and $10^{\circ} \mathrm{C}$.

\subsubsection{Discussion}

The effects of a sudden temperature drop from mesophilic conditions $\left(35^{\circ} \mathrm{C}\right)$ to low temperatures $\left(10-25^{\circ} \mathrm{C}\right)$ on the SMA of the digester sludge showed that the digester sludge is well adapted to a wide range of temperature shocks $\left(10-35^{\circ} \mathrm{C}\right)$. After the cold temperature shock, no lag phase was found for methane production, SMA was constant in time at low temperatures, and the temperature dependence of the SMA of the digester sludge after applying the temperature shocks was similar to the ones at constant temperatures $\left(10-25^{\circ} \mathrm{C}\right)$. Latter is confirmed by the equal SMA at suddenly decreasing temperature and constant temperature conditions, and non-existence of a lag phase after the suddenly decreasing temperature. 

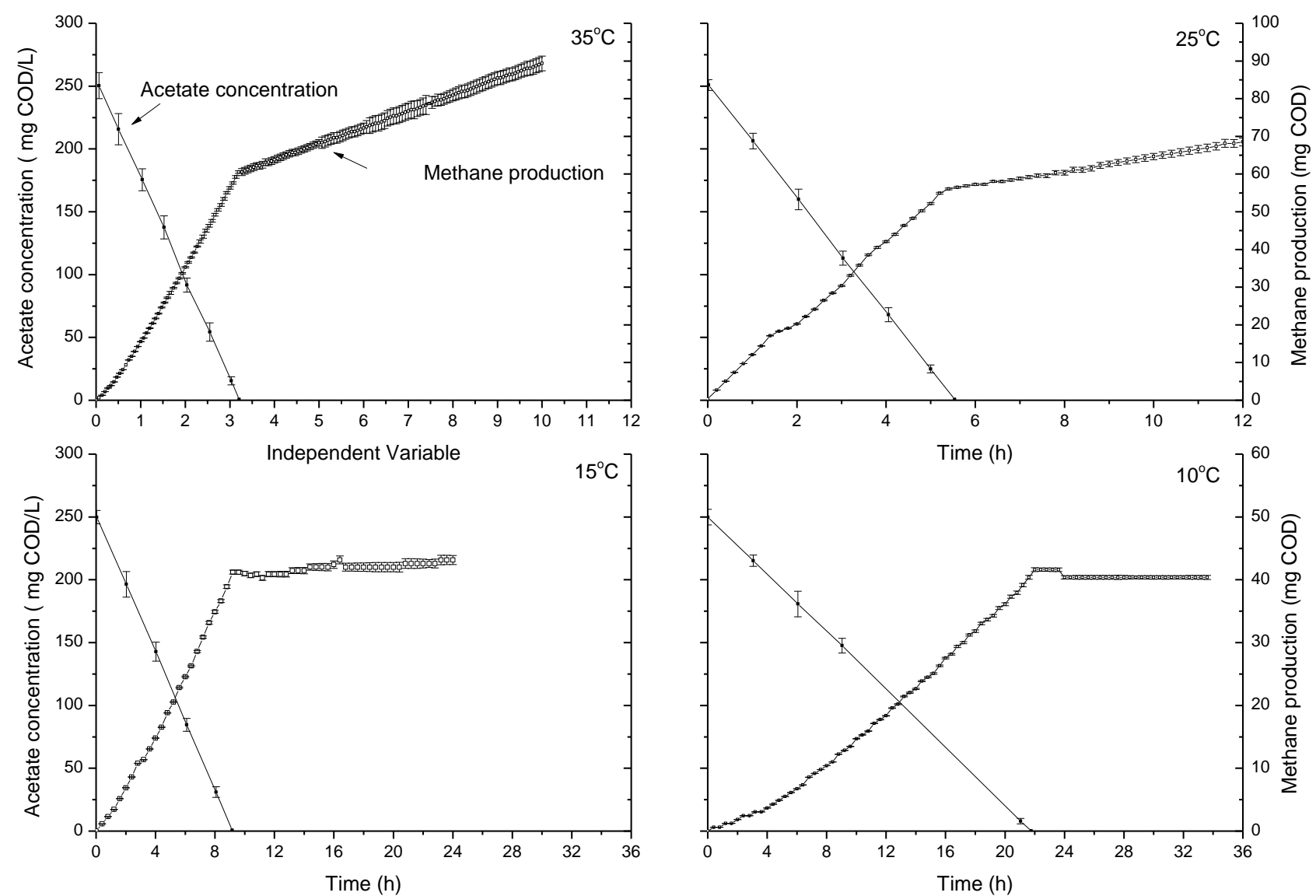

Fig.6.3 Methane production and substrate acetate concentration during the affinity of the digester sludge test at different temperatures $35,25,15$ and $10^{\circ} \mathrm{C}$ 
Lag phase, $E_{a}, K_{s}$ and SMA of different types of sludge at different temperatures were shown in Table 6.1. Lag phase was found when performing SMA tests using sludge from low temperature anaerobic reactors (Kettunen \& Rintala, 1997a; Luostarinen \& Rintala, 2005). The temperature dependence of the SMA can be well fitted by an Arrhenius equation (Fey \& Conrad, 2000; Kettunen \& Rintala, 1997a; McKeown et al., 2009b; Rebac et al., 1999a; Rebac et al., 1995), and $\mathrm{E}_{\mathrm{a}}$ was between 52-68 kJ/mol. SMA of the anaerobic sludge under mesophilic conditions were higher than psychrophilic conditions. Therewith, the anaerobic sludge was still mesophilic after treating low temperature wastewater for a long term operation.

$\mathrm{K}_{\mathrm{s}}$ value varied due to different conditions as shown in Table 6.1. Affinity of the digester sludge for acetate in this study was high between $10-35^{\circ} \mathrm{C}$. The methanogens with a high affinity for acetate could be enriched as they were mainly grown under a low acetate concentration in the UASB-digester. The methanogenic capacity of the low temperature UASB reactor calculated using SMA and sludge quantity in the UASB reactor matched with the measured methane production (Zhang et al., 2013), and this equality supports that the sludge had a high affinity for acetate. Methanogenic community revealed an overall dominance of the Methanosaeta in the UASB-digester sludge operated between $10-20^{\circ} \mathrm{C}$ (Zhang et al., 2016b). Methanosaeta was categorized as acetoclastic methanogens and had a minimum threshold concentration of 0.5-5.0 mg COD/L (Jetten et al., 1992) and a high affinity. $\mathrm{K}_{\mathrm{s}}$ of the Methanosaeta dominating sludge and Methanosaeta soehngenii was $45 \mathrm{mg}$ COD/L and $30 \mathrm{mg}$ COD/L, respectively (Fukuzaki et al. (1990); Pavlostathis \& Giraldo-Gomez, 1991a). At low temperatures, bacteria can change the membrane lipid composition, e.g. increase fatty acid unsaturation and decrease average chain length. The change improves the fluidity of the membrane and compensates the difficult transition of substrate at low temperatures (Nedwell, 1999). Therewith, they can maintain the high affinity as temperature dropped.

\subsection{Conclusions}

Sludge from an UASB-digester process treating municipal wastewater and continuously exposed to temperature changes from 35 to $12.5^{\circ} \mathrm{C}$ was shown to have:

- no lag phase in methane production after a sudden temperature drop from 35 to 20 , 15 or $10^{\circ} \mathrm{C}$

- temperature dependence of SMA of the digester sludge with a sudden temperature drop was similar to that at constant temperatures, and $E_{a}$ was $62 \mathrm{~kJ} / \mathrm{mol}$

- a high affinity for acetate at low temperatures of $35,25,15$ and $10^{\circ} \mathrm{C}$, and $\mathrm{K}_{\mathrm{s}}$ was $6.5 \mathrm{mg} \mathrm{COD} / \mathrm{L}$ for $35^{\circ} \mathrm{C}$ and almost 0 for the rest temperatures.

The results play an important role in understanding the performance of a UASBdigester progress treating low temperature municipal wastewater, and optimizing its design. 


\section{Acknowledgements}

The authors thank STOWA (Foundation for Applied Water Research), Paques BV, RVO (Netherlands Enterprise Agency), Hoogheemraadschap de Stichtse Rijnlanden, Hoogheemraadschap van Rijnland, Waterschapsbedrijf Limburg, Waterschap Drents Overijsselse Delta, Waterschap Rivierenland en Waternet for supporting this research. 


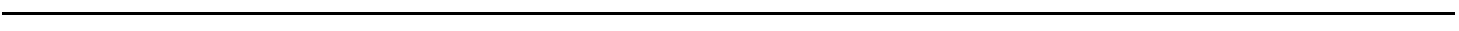




\section{General Discussion}




\subsection{Introduction}

Municipal wastewater must be well treated before being discharged into receiving water thus reducing its impact on the environment. Conventionally, municipal wastewater is treated aerobically, applying the activated sludge process, which consumes a lot of energy for aeration, and produces large amounts of biomass in the form of excess sludge. At the larger treatment plants, this produced sludge is in most cases anaerobically treated for biogas production. The formed biogas generally covers only a fraction of the energy needed for the aeration and other processes in the treatment. Therefore, other more energy efficient, waste water treatment processes are needed. Especially, at higher (tropical) temperatures, anaerobic treatment offers a good and energy effective alternative. However, at moderate temperature conditions, i.e. when in winter time sewage temperatures are as low as $10^{\circ} \mathrm{C}$, such an anaerobic treatment method is not yet available. For this reason, within this thesis, a new concept is studied and developed, that allows direct anaerobic treatment to municipal wastewater with temperatures as low as $10^{\circ} \mathrm{C}$. Direct anaerobic treatment increases the overall biogas yield and decreases energy cost for the treatment as compared to conventional aerobic treatment of municipal wastewater. The chemical energy of organic matter in the municipal wastewater is recovered in the form of methane. The effluent of the anaerobic treatment contains nitrogen and phosphorus which have to be removed to reach discharge standards. In (sub) tropical countries reuse of the nutrient (nitrogen, potassium and phosphorus) rich effluents can be applied for agricultural purposes, prevailing that pathogens are taken into account (Chernicharo et al., 2015). For low temperature climates reuse in agriculture is in general not attractive due to the relatively short crop seasons and removal of nitrogen and phosphorus from the anaerobic effluent is required. Anaerobic ammonium oxidation processes (Anammox) or denitrifying processes coupled to anaerobic methane oxidation (DAMO) could be applied for autotrophic nitrogen removal following the anaerobic pre-treatment of domestic wastewater (Hendrickx et al., 2012; Kampman et al., 2012).

In this thesis, anaerobic treatment of municipal wastewater at low temperatures applying a UASB-digester system was studied. The UASB reactor was operated at a short hydraulic retention time ( 6 hours) and low temperature varying between $10-20^{\circ} \mathrm{C}$. The high organic load results in accumulation of non-stabilized suspended solids in the UASB sludge bed. The accumulated sludge is, therefore, recycled over a mesophilic digester, in order to convert the suspended solids to biogas and produce methanogenic and other relevant anaerobic biomass for converting dissolved COD in the low temperature UASB reactor. Sludge recirculation rate, sludge transfer point, co-digestion and operation of the UASB-digester at $10-20^{\circ} \mathrm{C}$ were investigated. The imposed recirculation of the sludge from the UASB reactor to the digester and back, results in the exposure of the sludge to varying temperature conditions. Therefore, the effects of changing temperatures on hydrolysis and methanogenesis were also studied. This chapter finally discusses the potential application of the new municipal wastewater treatment concept including post-treatment for nitrogen and phosphorus removal. 


\subsection{Operation of a UASB-digester treating municipal}

\section{wastewater}

\subsubsection{Sludge recirculation rate and the sludge transfer point}

The sludge recirculation rate between the UASB reactor and the digester influences the performance of the UASB-digester system e.g. COD removal and methane production. The recirculation rate should be sufficiently high for transferring the largest portion of the fresh suspended solids to the digester for production of biogas and anaerobic biomass. However, the recirculation of the UASB sludge to the digester consumes energy for pumping and heating. The balance between energy production (related to the generated methane gas) and consumption (pumping and heating) is a key factor for application.

Increasing sludge recirculation rate improves the COD removal efficiency, mainly as a result of the increased dissolved COD efficiency, of a UASB-digester system (chapter 2). Biogas production of the digester clearly increased from 0.06 to $0.15 \mathrm{~m}^{3}$ biogas $/\left(\mathrm{m}^{3}\right.$ wastewater $\left.\mathrm{d}\right)$ as the sludge recirculation rate increased from 0.9 to $2.6 \%$ of the influent flow rate. This increase of biogas production was attributed to an increased transfer of fresh influent organic solids to the digester. Increasing sludge recirculation further, from $2.6 \%$ to $12.5 \%$, didn't result in a significant rise in methane production by the digester. This indicated that a recirculation rate of $2.6 \%$ of the influent flow rate should be sufficient for transferring the influent fresh organic solids from the UASB reactor to the digester (Chapter 2). The stability and specific methanogenic activity (SMA) of the UASB sludge increased with an increased SRR from 0.9 to $2.6 \%$ due to less accumulation of influent organic solids in the UASB reactor. COD removal efficiency and methane recovery increased correspondingly.

The sludge recirculation rate needed for adequate functioning of the combined system is strongly depending on the distribution of the solids in the UASB sludge bed and the sludge concentration. When the sludge bed approaches a CSTR, the required sludge recirculation rate will be high, while a plug flow behavior of the sludge bed could allow for a reduced sludge recirculation rate. The UASB reactor in the UASB-digester system described in this thesis behaved like a CSTR reactor as the SMA and stability of the UASB sludge was similar along the sludge bed. However, the sludge concentrations decrease with the height of the sludge bed in the reactor due to gravity. Therefore, the sludge transfer point should be chosen at a sludge bed height where the VSS concentration is adequate.

A high VSS concentration of the transferred sludge would benefit a low sludge recirculation rate and save heating and pumping energy. In chapter 2 , it is described that in our approach the transfer point was placed at the bottom of the sludge bed $(27 \mathrm{~cm}$ from the bottom), while Álvarez et al. (2004) and Mahmoud et al. (2004) applied a 
sludge transfer point at the top of the sludge bed. The appropriate height of the sludge transfer point for optimal suspended sludge (SS) recirculation in practice should be again determined under full scale conditions. This is because sludge distribution over the height of the reactor can substantially differ between laboratory and full scale applications.

\subsubsection{Co-digestion}

Co-digestion, adding extra organic matter to the digester of a UASB-digester, clearly improved methanogenic capacity of the low temperature UASB reactor and therewith increased its soluble COD removal efficiency (chapter 3). Co-digestion can be applied for municipal wastewater that has a high ratio in influent soluble COD to suspended $\mathrm{COD}$, to increase the biomass yield in the digester for transfer to the UASB reactor. Glucose was used in this study as a model substrate to investigate the feasibility of codigestion. The addition of the co-substrate was about $16 \%$ of the influent organic loading rate (36\% of the biodegradable influent organic load). However, this amount of co-substrate addition was not optimized yet.

When a higher soluble COD load on the aerobic posttreatment and a lower biogas production rate are not desired at times of low waste water temperatures, co-digestion is suggested as a method to mitigate UASB instability when temperature falls below critical levels and/or soluble COD loads increase. This will increase the methanogenic capacity of the UASB reactor at low temperature, which would otherwise not be sufficient for complete conversion of biodegradable dissolved COD. For application in practice, a low nitrogen and phosphorus containing co-substrate is recommended in order to limit the additional nitrogen and phosphorus loading on the post-treatment steps.

\subsubsection{Operation at temperatures decreasing from 20 to $10^{\circ} \mathrm{C}$}

Anaerobic treatment of municipal wastewater using a UASB-digester achieved an average COD removal of $60 \pm 4.6 \%$ at temperatures of $12.5-20^{\circ} \mathrm{C}$ (chapter 4 ). The UASB reactor was operated at an HRT of 6 hours, the digester was operated at an HRT of $15 \mathrm{~h}$, a temperature of $35^{\circ} \mathrm{C}$ and a sludge recirculation rate of $16 \%$ of the influent flow rate was applied. The ratio between the UASB reactor and digester volume is $130 / 50$ (L). A high sludge recirculation rate is applied to show the 'proof of principle' and can be further optimized.

COD removal efficiency was lower $(51.5 \pm 5.5 \%)$ at $10^{\circ} \mathrm{C}$ in comparison to that at a temperature of $12.5-20^{\circ} \mathrm{C}$. The decrease in COD removal efficiency at $10^{\circ} \mathrm{C}$ coincided with an increased influent COD concentration. The increased effluent VFA concentration shows a limited methanogenic capacity of the UASB sludge to cope with the combination of a decreased temperature and an increased loading rate. Yet, codigestion could be applied under such conditions to enhance the methanogenic capacity of the low temperature UASB reactor. 
At temperatures between $10-20^{\circ} \mathrm{C}$ a mean suspended COD removal of $76.0 \pm 9.1 \%$ can be achieved in a UASB-digester system treating municipal wastewater. This is similar to the results of Mahmoud et al. (2004) achieved at a UASB temperature of $15^{\circ} \mathrm{C}$. The results are similar as reported by Chernicharo (2006) who studied the application of the UASB reactor for municipal wastewater treatment at tropical conditions.

Colloidal COD removal efficiency is limited to $42.8 \pm 17.5 \%$ at $12.5-20^{\circ} \mathrm{C}$. Colloidal COD can be removed by bio flocculation in aerobic reactors (Li et al., 2011). Removal of colloidal COD is in general low when applying anaerobic treatment of municipal sewage at low temperatures (Álvarez et al., 2008).

$\mathrm{COD}_{\text {soluble }}$ removal efficiency fluctuated probably due to the difference in influent BMP

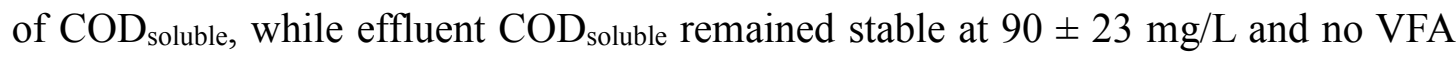
could be determined in the effluent at temperatures between $12.5-20^{\circ} \mathrm{C}$. The effluent $\mathrm{COD}_{\text {soluble }}$ concentration was similar as reported by (Hülsen et al., 2016). Chernicharo et al. (2015) achieved a lower effluent COD $_{\text {soluble }}$ of $30 \pm 36 \mathrm{mg} / \mathrm{L}$ using a UASBdigester system, which in those cases was mainly due to a low influent $\mathrm{COD}_{\text {soluble }}$ concentration of $50 \pm 10 \mathrm{mg} / \mathrm{L}$.

Methane production accounts for $39.7 \pm 4.4 \%$ of the influent $\mathrm{COD}$ at $10-20^{\circ} \mathrm{C}$, which is $80 \%$ of influent BMP. In the UASB reactor, $49 \%$ of the total methane production is produced of which $63 \%$ leaves the UASB dissolved in the effluent and $37 \%$ as biogas. This high amount of dissolved methane may offer an opportunity in future to introduce DAMO for further nitrogen removal from the effluent (Kampman et al., 2012). However, although the principle of DAMO has been proven (Hendrickx et al., 2012), the technology needs still extensive developments to reach practical full scale application. The high amounts of methane in effluents pose a problem of greenhouse gas emission to the atmosphere. To make anaerobic wastewater treatments climate change neutral, methane recovery or removal from effluents is an important issue that needs to be addressed in future. Given that $25 \%$ of the influent COD can be converted to methane gas, excluding the dissolved methane lost with the effluent, the generated energy is sufficient for the heating of about $3 \%$ of the influent flow from $10^{\circ} \mathrm{C}$ to $35^{\circ} \mathrm{C}$. At a recirculation rate of $2.6 \%$ (Chapter 2), the produced energy is sufficient for sludge heating. To improve the energy balance, the following methods can be applied: a) optimize sludge recirculation: b) concentrate the recirculated UASB sludge by sludge sedimentation/filtration prior to transfer to the digester; c) run the digester at $30^{\circ} \mathrm{C}$; d) apply a heat exchanger for the recirculated sludge. These items are therefore proposed for further optimization of the UASB-digester system towards full scale application, and briefly elaborated at the end of this chapter.

\subsubsection{Effect of temperature fluctuation on methanogenesis}

No lag phase was found for methanogenic activity of the digester sludge after suddenly decreasing the temperature from mesophilic conditions $\left(35^{\circ} \mathrm{C}\right)$ to temperatures of 10 , 15 and $25^{\circ} \mathrm{C}$ (chapter 5). The temperature dependency of the SMA is the same at constant temperatures and fluctuating temperature conditions. The sludge in a UASB- 
digester system recirculates between a low temperature $\left(10-20^{\circ} \mathrm{C}\right)$ and a high temperature $\left(35^{\circ} \mathrm{C}\right)$ environment. Given the high SMA at $35^{\circ} \mathrm{C}$, in comparison to the lower temperatures, of the digester and the UASB sludge, the sludge can be characterized as mesophilic.

The affinity of the digester sludge for acetate was high at temperatures of $10-35^{\circ} \mathrm{C}$. The dominant methanogens in the digester and the UASB sludge were Methanosaetaceae and Methanomicrobiales methanogens (Chapter 4). These methanogens have a high affinity for acetate and a high methanogenic activity even at minimum substrate concentrations between $0.5-5 \mathrm{mg} \mathrm{COD} / \mathrm{L}$ at $35^{\circ} \mathrm{C}$ (Álvarez et al., 2008). The UASB sludge had, as expected, a similar microbial structure as the digester sludge and therefore also a high affinity for acetate. This was confirmed by the fact that the methane production of the UASB reactor (including dissolved methane) matched well with the methanogenic capacity at $12.5-20^{\circ} \mathrm{C}$ (Chapter 3 and 4 ).

\subsubsection{Short-term pre-hydrolysis at mesophilic condition enhances low}

\section{temperature hydrolysis}

The recirculated sludge was exposed to temperatures, fluctuating between the low temperature in the UASB reactor and the mesophilic temperature in the digester. Therefore, effects of a pre-hydrolysis of organic matter at mesophilic conditions on hydrolysis at low temperature was studied. Hydrolysis tests were executed, applying granular sludge as inoculum from a paper industry in Eerbeek, the Netherlands at low temperatures $\left(10-25^{\circ} \mathrm{C}\right)$ with and without a short pre-hydrolysis at mesophilic conditions, using cellulose and tributyrin as substrate (Chapter 6). A short prehydrolysis step at $35^{\circ} \mathrm{C}$ clearly increases the first order hydrolysis rate constant for cellulose at low temperatures $\left(10-25^{\circ} \mathrm{C}\right)$. A long lag phase of 40-60 days is occurring when applying cellulose hydrolysis at $10-15^{\circ} \mathrm{C}$. The latter indicates that cellulase production is limiting hydrolysis during start-up. No lag phase is occurring at low temperature conditions when pre-hydrolysis at $35^{\circ} \mathrm{C}$ is applied. This increased hydrolysis rate constant of cellulose at low temperatures is hypothesized to be due to an excess cellulase production during pre-hydrolysis at $35^{\circ} \mathrm{C}$.

For cellulose, hydrolysis yield clearly decreases from $100 \%$ to $9.6 \%$ as temperature decreased from 35 to $10^{\circ} \mathrm{C}$. This decrease in yield with temperature decrease can be due to the crystalline structure of cellulose. The yield at $10^{\circ} \mathrm{C}$, after a short prehydrolysis period at $35^{\circ} \mathrm{C}$ amounts to $40 \%$ in 9.1 days, while that at $10^{\circ} \mathrm{C}$ without prehydrolysis is only $9.6 \%$, achieved in 62 days. This clearly shows that hydrolysis of cellulose, initiated at high temperatures (in our system, the digester) can remain active at low temperatures (in our system, the UASB reactor).

Hydrolysis tests were executed at $35^{\circ} \mathrm{C}$, using the supernatant of the digestate after batch digestion of cellulose and tributyrin at $10-35^{\circ} \mathrm{C}$ to test abovementioned hypothesis. The higher determined hydrolytic activity of the supernatant collected from the digestate at $35^{\circ} \mathrm{C}$ as compared to that of the supernatants collected at low 
temperatures $\left(\leq 25^{\circ} \mathrm{C}\right)$ digestates confirms the hypothesis that excess cellulases are excreted during pre-digestion at $35^{\circ} \mathrm{C}$ and can remain active at lower temperatures.

These excess cellulases accelerate the hydrolysis when temperature decreases after a period of high temperature. The increased production of dissolved COD in the UASB reactor as compared to the influent dissolved COD, as observed in the present research (Chapter 4), can be ascribed to the extra hydrolysis as a result of the transferred excess enzymes from the digester to the UASB, in a UASB-digester system. The UASB reactor needs to be designed based on this extra dissolved COD load.

\subsection{Outlook}

\subsubsection{New municipal wastewater treatment}

A new concept of municipal wastewater treatment can be achieved using anaerobic treatment as the core biological unit as shown in Fig. 7.1. A UASB-digester is proposed for moderate temperature climate zones, to convert organic material from municipal wastewater into energy, in the form of methane. Bio-flocculation followed by anaerobic sludge digestion, as applied in the AB process, is referred to as another alternative for activated sludge treatment (Faust et al., 2014; Verstraete et al., 2009). Main advantage as compared to direct anaerobic treatment of domestic sewage is the absence of dissolved methane in the liquid anaerobic effluent. However, it needs an energy input of $0.03 \mathrm{kWh} / \mathrm{m}^{3}$ (wastewater) for aeration (Khiewwijit et al. 2015). Chemical energy of $1.5-1.9 \mathrm{kWh}$ per $\mathrm{m}^{3}$ of wastewater can be recovered from municipal wastewater with an COD concentration of 400-500 mg/L (Owen, 1982).

Based on the new concept for upgrading the conventional municipal wastewater treatment plant, the primary sludge sedimentation tank and aeration basins can be replaced by a UASB reactor. Anammox or after further development DAMO processes can be used for autotrophic nitrogen removal (Hendrickx et al., 2012; Kampman et al., 2012).

Phosphorus is a limited resource, which used to be considered as pollutant in conventional wastewater treatment. Iron precipitation is often applied for the removal of phosphorus in conventional wastewater treatment (Parsons \& Smith, 2008). The product is however not suitable for reuse in agriculture (De-Bashan \& Bashan, 2004), therefore other techniques are required. Recently, (Drenkova-Tuhtan et al., 2016) published on the recovery of phosphate via a sorption/desorption technique, making use of phosphate specific absorbents viz. advanced nanocomposite magnetic particles. The pilot scale experiments results showed a 25-38 times higher phosphate concentration in the desorption as compared to the start solution. 


\section{Energy self-sufficient Wastewater Treatment process}

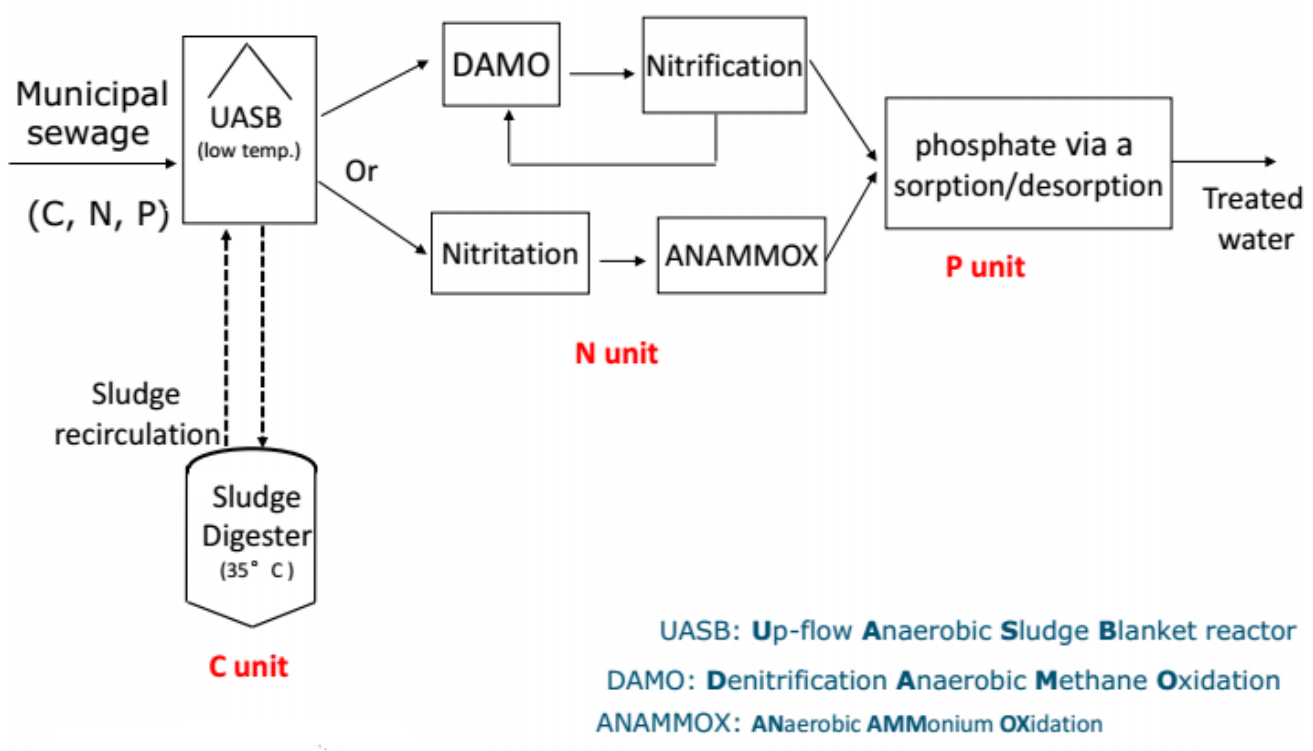

Fig.7.1 New concept of a wastewater treatment plant

The public, government, institutes and companies are involved in or affected by the upgrading of a municipal wastewater treatment plant. It would be fair when representatives of the public, who will pay for the chosen plan, get a chance to give their opinion about these plans. Design of a wastewater treatment plant can be assessed on cost-benefit analysis, safety and function (Guest et al., 2009). The plans should be accepted by the representatives of the public; otherwise new plans should be conceived. However, the interaction between different stakeholders, to decide upon the wastewater treatment process is insufficient or deficient in many countries e.g. China. In China, for a metropolitan area like Beijing, the government did choose the anaerobic anoxic oxic (A2O) process coupled with membrane filtration for municipal wastewater treatment for meeting the stringent standard. The government has to increase the wastewater disposal fee year by year due to the energy and cost consuming wastewater treatment plants, and this will reduce public acceptance. Therefore, a societal drive to reach energy and cost effective waste water treatment can be expected to also arise in China over time, and will create in China and elsewhere in the world a new market for these.

\subsubsection{Costs}

The operational costs of the new wastewater treatment concept using an anaerobic reactor for organic materials removal is much lower than a conventional wastewater treatment plant. No aeration is needed in the operation of anaerobic reactors, therewith saving electricity consumption. Complete aerobic BOD removal consumes $0.45 \mathrm{kWh}$, whereas complete anaerobic treatment produces $0.25 \mathrm{kWh}$ (Scherson \& Criddle, 2014). The produced heating energy and electricity can be utilized in the wastewater treatment 
plant itself, for controlling the temperature of the mesophilic sludge digester and for providing electricity for denitrification, aiming at an energy neutral process.

The excess sludge of a UASB-digester in this study was $8 \pm 5 \%$ of the influent COD, which is much lower than that of a conventional wastewater treatment plant (Chapter 4). The operational cost of excess sludge processing can be significantly reduced using anaerobic reactors due to the low amounts of sludge produced. In further developments, the sludge production due to chemical phosphorus removal and nitrogen removal should also be taken into account. E.g, the operational and maintenance costs are 1.21.7 euros /(inhabitant - year) for a Brazilian wastewater treatment plant applying a UASB reactor (Chernicharo et al., 2015), while the average costs for a conventional wastewater treatment plant was 40 euros/p.e/year in 2006 in the Netherlands (UVW, 2006). The absolute difference of the cost between these two case examples can be smaller considering the different sludge disposal and labor costs, and the different effluent discharge standard.

When applying a UASB-digester with a recirculation rate of $16 \%$ of the influent flow rate, methane production can compensate for only $20 \%$ of the heating energy of the digester, when operating the UASB at $10^{\circ} \mathrm{C}$ (Chapter 4). Strategies for saving energy are discussed in paragraph 7.2.3. The duration of winter time in countries with moderate climates is generally 3 months, and the time that the wastewater temperature decreases to $10^{\circ} \mathrm{C}$ is shorter. For different climatic conditions an energy balance over the year is to be established, to make a full feasibility evaluation of our proposed sewage treatment concept.

Another item is the resilience of the UASB-digester system to fluctuations in COD and flow of the sewage. Although in many countries rainwater collection will be uncoupled from sewage infrastructure (Arnaldos et al., 2015), which will be highly beneficial for anaerobic treatment technologies since the COD levels in sewage will significantly increase and fluctuate less, significant daily and seasonal fluctuations can still be expected (Agudelo-Vera et al., 2013). In this study, the UASB-digester approach was developed at constant flow and reduced fluctuation in influent COD concentration. In further optimization towards full application, these flow and COD fluctuations also need to be taken into account.

\subsubsection{Recommendations for further research}

This research showed that anaerobic treatment of municipal wastewater at $10-20^{\circ} \mathrm{C}$ using a UASB-digester system can achieve a robust COD removal and methane recovery. In a UASB-digester system, the major operational cost is energy consumption for heating the recirculated sludge. The mitigation methods for saving this energy have been discussed in paragraph 7.2.3 (operation at $20-10^{\circ} \mathrm{C}$ ) and chapter 4 .

The efficiency of the UASB-digester system treating municipal wastewater is mainly depending on COD composition ( $\mathrm{CODs}_{\text {uspended }} / \mathrm{COD}_{\text {soluble}}$ ), sludge retention and sludge recirculation rate. Operational parameters such as sludge recirculation rate and sludge 
recirculation point, HRT of the UASB reactor, temperature of the digester or codigestion should be adjusted according to the influent quality.

Separate collection and transport of rainwater and municipal wastewater will decrease hydraulic loading rate, increase COD concentration of the wastewater and reduce its variation. This definitely benefits the application of anaerobic wastewater treatment. There is a large potential for new sewer systems in countries with growing urbanization, where wastewater treatment plants are not present yet. Within so called 'New Sanitation' concepts, not only rainwater, but also black water (toilet water) and grey water are separately collected, transported and treated. So far, vacuum collection and transport is applied for the black water to achieve a sufficiently high concentration to allow for energy efficient mesophilic anaerobic treatment in countries with moderate climates. The here presented new treatment system would also allow for the collection and anaerobic treatment of less concentrated black water. The latter could enhance the implementation of 'New Sanitation'. In these concepts, technology robustness is important, and therefore the resilience of the UASB-digester system to fluctuations in flow, COD, and temperature is an important item for future full scale optimization.

The here proposed nitrogen removal processes, coupled to a UASB-digester system can save energy and do not require organic resources. ANAMMOX and DAMO processes are already studied individually (Kampman et al., 2012; Laureni et al., 2016; Lotti et al., 2015). The volumetric nitrite consumption rate of the DAMO process was shown to be not sufficient yet, and applying a membrane was suggested to increase the biomass retention (Kampman et al., 2012). The performance of ANAMMOX or DAMO, integrated with a UASB-digester system is suggested in further studies.

Pathogen removal should also be concerned for the post-treatment of the UASBdigester system to avoid the spreading of diseases. A downflow hanging sponge reactor can be used to remove pathogens, and guarantees the effluent COD concentration to comply with effluent discharge standards. The UASB-DHS system was tested in a demonstration-scale of $1000 \mathrm{~m}^{3} / \mathrm{d}$ capacity in India, where the system has been operated since 2003 (Tandukar et al., 2005).

The fate and the risks of micro-pollutants like pharmaceuticals in the effluent of wastewater treatment plants should be assessed due to a long term consideration of environmental safety. Due to its micro amount, it would be more effective to control from the source rather than the end. E.g. expired pharmaceutical or medicine waste should be collected separately. Still, most pharmaceuticals come from feces and urine (Butkovskyi et al., 2015). Butkovskyi et al. (2015) reported that the removal of pharmaceuticals in a UASB reactor can be better or similar, depending on specific pharmaceuticals, compared to conventional wastewater treatment plants. Poor pharmaceutical removal is expected using a UASB-digester system for sewage treatment, due to the low activity of the UASB sludge at low temperatures. Proper posttreatment, like activated carbon is required (Hernández-Leal et al., 2011), while the energy, costs and removal performance needs to be balanced.

Methane is a greenhouse gas and is emission that should be prevented within the new 
wastewater treatment concept. The dissolved methane increases when temperature decreases, which is a key issue for application of anaerobic treatment in moderate countries. The DAMO process is suggested as it can remove dissolved methane and nitrogen together. Besides, a membrane technology such as hollow-fiber membranes and a poly-di-methyl-siloxane (PDMS) membrane contactor can be used for degasification and to strip the dissolved methane respectively (Cookney et al., 2012; Hatamoto et al., 2010). Two subsequent stages of DHS were applied to successfully aerobically oxidize the remaining effluent dissolved methane (Matsuura et al., 2015). Besides, vacuum degasification was studied to transfer dissolved gas in the liquid of the UASB reactor inside the membrane, and COD removal efficiency was increased from $83 \%$ to $90 \%$ (Bandara et al., 2013). However, the economic assessment and energy consumption should be considered before applying these technologies.

Demonstration is the most effective and strongest way to spread the new wastewater treatment concept. Operation experience can be gained through the demonstration which benefits the dissemination of the knowledge of the UASB-digester system. For example, energy recovery from waste-water treatment is considered as one of alternative energy supply technologies in Canada (Cuddihy et al., 2005). The same argument is applicable to China and other parts of the world, where energy friendly wastewater treatment plants are attractive also for rural areas where low operational costs are an important societal boundary condition for effective waste water technology innovation and implementation. 


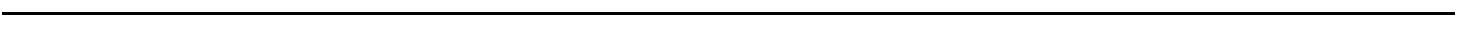


Summary 


\section{Summary}

A new wastewater treatment concept, applying direct anaerobic treatment of low temperature municipal wastewater is studied within this thesis. The treatment concept results in an increased biogas yield and decreased energy consumption as compared to conventional treatment of municipal wastewater. Chemical energy of organic matter in the municipal wastewater is recovered in the form of methane. The dissolved methane in the effluent could, concurrently with nitrogen, be removed via the denitrifying anaerobic methane oxidation (DAMO) process. Alternatively, the anaerobic ammonium oxidation process (ANAMMOX) could be applied for autotrophic nitrogen removal following the anaerobic treatment of domestic wastewater. Applying such a chain of different biological conversion technologies, can change the treatment of municipal wastewater from energy consuming to energy self-sufficient. In this study, anaerobic treatment of municipal wastewater at low temperatures applying a system of a combination of an upflow anaerobic sludge bed (UASB) reactor and a sludge-digester (UASB-digester) was studied.

Chapter 1 gives a literature review on anaerobic wastewater treatment. Municipal wastewater, as one of the main pollution sources of water systems, must be treated before being discharged into receiving surface waters, to avoid water resource pollution. Anaerobic wastewater treatment can be an alternative to reduce energy consumption and operational costs. However, low temperature is still a challenge for anaerobic wastewater treatment of municipal wastewater due to the low hydrolysis rate of organic solids and the low growth rate of methanogenic biomass needed for biogas production.

Among the anaerobic reactors, designed for low temperature treatment, a UASBdigester is a promising system as, next to removal of dissolved and particulate organics, also biodegradable organic particles are entrapped and converted to methane. Therefore, it provides stabilized excess sludge unlike other anaerobic two phase systems, like the anaerobic filter $(\mathrm{AF})$ - anaerobic hybrid $(\mathrm{AH})$ reactor or hydrolytic upflow sludge bed (HUSB) reactor - UASB (or expanded granular sludge bed EGSB) system, that produce sludge that needs further stabilization. The temperature of domestic wastewater in moderate climate zones can be as low as $10^{\circ} \mathrm{C}$ and therefore the feasibility of the UASB-digester also needs to be assessed at temperatures below $15^{\circ} \mathrm{C}$, which has not been done prior to this study. For this purpose, a pilot-scale UASB-digester was studied, and the temperature was subsequently decreased in steps to $10^{\circ} \mathrm{C}$.

A pilot scale UASB-digester system was applied to treat real domestic sewage of Bennekom, the Netherlands. Effects of sludge recirculation rate and height of the UASB sludge transfer point were studied in Chapter 2. A sludge recirculation rate of $1 \%, 2.6 \%$ and $12.5 \%$ of the influent flow rate was investigated. The total COD removal efficiency increases with the sludge recirculation rate. A sludge recirculation rate of $1 \%$ of the influent flow rate leads to organic solids accumulation in the UASB reactor. The stability of the UASB sludge and the biogas production in the digester substantially improve when increasing the recirculation from $1 \%$ to $2.6 \%$, from 0.37 to $0.15 \mathrm{~g} \mathrm{CH}_{4}$ $\mathrm{COD} / \mathrm{g}$ COD and from 2.9 to $7.4 \mathrm{~L} / \mathrm{d}$, respectively. No further improvement is shown 
at a recirculation rate of $12.5 \%$ of the influent flow rate, but the biogas production in the UASB increases from $0.37 \mathrm{~L} / \mathrm{d}$ to $1.2 \mathrm{~L} / \mathrm{d}$. A sludge recirculation rate of approximately $3 \%$ of the influent flow rate is recommended. Additionally, different sludge transfer points were studied. A higher sludge transfer point results in an increased suspended COD removal efficiency and VSS concentration of the UASB sludge bed.

Co-digestion in the digester of the UASB-digester was studied, to enable efficient treatment of municipal wastewater with a high dissolved/suspended COD ratio at low temperatures. (Chapter 3). Glucose was chosen as a model co-substrate. Co-substrate was added in the sludge digester to produce additional methanogenic biomass, which was continuously recycled to inoculate the UASB reactor. Soluble COD removal efficiency increases from 6 to $23 \%$, when applying co-substrate $16 \%$ of influent organic loading rate to the digester. The soluble COD removal equals the biodegradability of the influent dissolved COD. Specific methanogenic activity (SMA) of the UASB and of the digester sludge at $15^{\circ} \mathrm{C}$ triples to a value of respectively 43 and $39 \mathrm{mg} \mathrm{CH}_{4}$ $\mathrm{COD} /(\mathrm{g}$ VSS $\cdot \mathrm{d})$. Methane production in the UASB reactor almost doubled due to a twofold increase in methanogenic capacity.

A pilot scale UASB-digester was studied to treat domestic wastewater at temperatures of $10-20^{\circ} \mathrm{C}$ and an HRT of $6 \mathrm{~h}$ in the UASB reactor and an HRT of $15 \mathrm{~h}$ in the digester (Chapter 4). The COD removal efficiency remains stable at $60 \pm 4.6 \%$ when decreasing the temperature from 20 to $12.5^{\circ} \mathrm{C}$; it decreases to $51.5 \pm 5.5 \%$ at $10^{\circ} \mathrm{C}$. The decreased COD removal efficiency at $10^{\circ} \mathrm{C}$ is attributed to an increased influent COD load, leading to insufficient methanogenic capacity of the UASB reactor. Suspended COD $\left(\mathrm{COD}_{\text {sus }}\right)$ removal efficiency is $76.0 \pm 9.1 \%$ at temperatures of $10-20^{\circ} \mathrm{C}$. Soluble COD removal $\left(\mathrm{COD}_{\mathrm{sol}}\right)$ fluctuates due to variation of the influent $\mathrm{COD}$ concentration, but the average effluent COD concentration is $90 \pm 23 \mathrm{mg} / \mathrm{L}$ at temperatures between 12.5 and $20^{\circ} \mathrm{C}$. The methane production is $39.7 \pm 4.4 \%$ of the influent COD, which is $80 \%$ of influent biological methane potential (BMP); $49 \%$ is produced in the UASB reactor and $51 \%$ in the digester; $31 \%$ of the produced methane is dissolved in the UASB effluent. Discharged sludge accounts for $8 \pm 5 \%$ of the influent COD. The methanogenic community is dominated by the acetoclastic Methanosaetaceae and the hydrogenotrophic Methanomicrobiales during the operation of a UASB $\left(10-20^{\circ} \mathrm{C}\right)-$ digester $\left(35^{\circ} \mathrm{C}\right)$ for domestic sewage treatment.

In Chapter 5 low temperature $\left(10-25^{\circ} \mathrm{C}\right)$ hydrolysis was investigated with and without application of a short pre-hydrolysis step at $35^{\circ} \mathrm{C}$. Batch experiments were executed using cellulose and tributyrin as model substrates for carbohydrates and lipids. The low temperature anaerobic hydrolysis rate constant increases by a factor of 1.5 to 10 , when a short anaerobic pre-hydrolysis step at $35^{\circ} \mathrm{C}$ is applied. After the pre-hydrolysis step at $35^{\circ} \mathrm{C}$, no lag phase occurs at temperatures between 10 and $25^{\circ} \mathrm{C}$. Without prehydrolysis, the lag phase for cellulose hydrolysis at $35-10^{\circ} \mathrm{C}$ is $4-30$ days. Tributyrin hydrolysis shows no lag phase at any temperature. The hydrolysis efficiency of cellulose, after 9.1 days batch digestion at 15 and $10^{\circ} \mathrm{C}$, increases from 40 to $62 \%$ and from 9.6 to $40 \%$, respectively, when pre-hydrolysis at $35^{\circ} \mathrm{C}$ is applied. Pre-hydrolysis 
does not affect the hydrolysis efficiency of tributyrin. The hydrolytic activity of the supernatant, collected from the digestate after batch digestion of cellulose and tributyrin at $35^{\circ} \mathrm{C}$, is higher than that of the supernatants collected from low temperature $\left(\leq 25^{\circ} \mathrm{C}\right)$ digestates. This effect of pre-hydrolysis at $35^{\circ} \mathrm{C}$ should be taken into account in the design of a UASB-digester system, as it may increase the soluble COD load on the UASB reactor.

In a UASB-digester system, the sludge is continuously exposed to changing temperatures, as the sludge is recirculated from the low temperature UASB reactor to the warm digester and back. Effects of an immediate temperature drop from $35^{\circ} \mathrm{C}$ to 25 , 15 or $10^{\circ} \mathrm{C}$ on the methanogenic activity and the effects of temperature $\left(10-35^{\circ} \mathrm{C}\right)$ on affinity constant for acetate using the digester sludge from a UASB-digester process, were studied in batch experiments in Chapter 6. Digester sludge of a UASB $\left(12.5^{\circ} \mathrm{C}\right)$ sludge digester $\left(35^{\circ} \mathrm{C}\right)$ was fed with acetate at constant temperatures of $10-35^{\circ} \mathrm{C}$ and at varying temperatures from $35^{\circ} \mathrm{C}$ to 25 , to 15 to $10^{\circ} \mathrm{C}$. No lag phase in methane production rate occurs when applying temperature shocks from $35^{\circ} \mathrm{C}$ to 25,15 , and $10^{\circ} \mathrm{C}$. The temperature dependency of the specific methanogenic activity (SMA) of the digester sludge after the temperature shocks is similar to that at constant temperatures. The activation energy for the SMA of the digester sludge is $62 \mathrm{~kJ} / \mathrm{mol}$. Acetate affinity of the digester sludge is high at temperatures between 10 and $35^{\circ} \mathrm{C}$ with apparent affinity constants $\leq 6 \mathrm{mg} \mathrm{COD} / \mathrm{L}$.

The results of this research are discussed in Chapter 7. The results of the present research show that anaerobic treatment of municipal wastewater at $10-20^{\circ} \mathrm{C}$ using a UASB-digester system can achieve a robust COD removal and methane recovery. Especially the good performance at $10^{\circ} \mathrm{C}$ had not been shown previously. This was achieved when applying a UASB-digester with a recirculation rate of $16 \%$ of the influent flow rate. At this recirculation rate, methane production can compensate for only $20 \%$ of the heating energy of the digester, when operating the UASB at $10^{\circ} \mathrm{C}$ (Chapter 4). Strategies for saving energy are a) optimize sludge recirculation: b) concentrate the recirculated UASB sludge by sludge sedimentation prior to the digester; c) run the digester at $30^{\circ} \mathrm{C}$; d) apply a heat exchanger for the recirculated sludge.

The integration of nitrogen removal with ANAMMOX or DAMO, with a UASBdigester is suggested for further research. Also, the recovery or conversion of dissolved methane in the effluent is suggested for further research, as its emission to the atmosphere should be avoided, given its high global warming potential. Furthermore, the recovery of phosphate after anaerobic treatment should be considered, as it is a finite resource. Although recovery technologies are available for concentrated phosphate solution, recovery from diluted sewage still requires further research. Demonstration of the UASB-digester system at a larger scale is required for gaining more real operational experience. 
Literature 
Literature

1. Adney, W.S., Rivard, C.J., Shiang, M., Himmel, M.E. 1991. Anaerobic digestion of lignocellulosic biomass and wastes - Cellulases and related enzymes. Applied Biochemistry and Biotechnology, 30(2), 165-183.

2. Agudelo-Vera, C.M., Keesman, K.J., Mels, A.R., Rijnaarts, H.H.M. 2013. Evaluating the potential of improving residential water balance at building scale. Water Research, 47(20), 7287-7299.

3. Ahmed, F., Siwar, C., Begum, R.A. 2014. Water resources in Malaysia: Issues and challenges. Journal of Food, Agriculture and Environment, 12(2), 1100-1104.

4. Aiyuk, S., Forrez, I., Lieven, D.K., van Haandel, A., Verstraete, W. 2006. Anaerobic and complementary treatment of domestic sewage in regions with hot climates-A review. Bioresource Technology, 97(17), 2225-2241.

5. Álvarez, J.A., Armstrong, E., Gómez, M., Soto, M. 2008. Anaerobic treatment of low-strength municipal wastewater by a two-stage pilot plant under psychrophilic conditions. Bioresource Technology, 99(15), 7051-7062.

6. Álvarez, J.A., Armstrong, E., Presas, J., Gómez, M., Soto, M. 2004. Performance of a UASB-digester system treating domestic wastewater. Environmental Technology, 25(10), 1189-1199.

7. Angenent, L.T., Abel, S.J., Sung, S. 2002. Effect of an organic shock load on the stability of an anaerobic migrating blanket reactor. Journal of Environmental Engineering, 128(12), 1109-1120.

8. Angenent, L.T., Banik, G.C., Sung, S. 2001. Anaerobic migrating blanket reactor treatment of low-strength wastewater at low temperatures. Water Environment Research, 73(5), 567-574.

9. APHA. 1998. Standard Methods for the Examination of Water and Wastewater. American Public Health Association, Washington, DC.

10. Arnaldos, M., Amerlinck, Y., Rehman, U., Maere, T., Van Hoey, S., Naessens, W., Nopens, I. 2015. From the affinity constant to the half-saturation index: Understanding conventional modeling concepts in novel wastewater treatment processes. Water Research, 70, 458-470.

11. Arnell, N.W. 2004. Climate change and global water resources: SRES emissions and socio-economic scenarios. Global Environmental Change, 14(1), 31-52.

12. Azman, S., Khadem, A.F., Van Lier, J.B., Zeeman, G., Plugge, C.M. 2015. Presence and role of anaerobic hydrolytic microbes in conversion of lignocellulosic biomass for biogas production. Critical Reviews in Environmental Science and Technology, 45(23), 2523-2564.

13. Bandara, W.M.K.R.T.W., Ikeda, M., Satoh, H., Sasakawa, M., Nakahara, Y., Takahashi, M., Okabe, S. 2013. Introduction of a degassing membrane technology into anaerobic wastewater treatment. Water Environment Research, 85(5), 387-390.

14. Bandara, W.M.K.R.T.W., Kindaichi, T., Satoh, H., Sasakawa, M., Nakahara, Y., Takahashi, M., Okabe, S. 2012. Anaerobic treatment of municipal wastewater at ambient temperature: Analysis of archaeal community structure and recovery of dissolved methane. Water Research, 46(17), 5756-5764.

15. Banik, G.C., Viraraghavan, T., Dague, R.R. 1998. Low temperature effects on 
anaerobic microbial kinetic parameters. Environmental Technology, 19(5), 503512.

16. Barber, W.P., Stuckey, D.C. 1999. The use of the anaerobic baffled reactor (ABR) for wastewater treatment: A review. Water Research, 33(7), 1559-1578.

17. Batstone, D.J., Keller, J., Angelidaki, I., Kalyuzhnyi, S.V., Pavlostathis, S.G., Rozzi, A., Sanders, W.T., Siegrist, H., Vavilin, V.A. 2002. The IWA Anaerobic Digestion Model No 1 (ADM1). Water Science and Technology, 45(10), 65-73.

18. Beas, R.E.Y., Kujawa-Roeleveld, K., Zeeman, G., Van Lier, J.B. 2015. A downflow hanging sponge (DHS) reactor for faecal coliform removal from an upflow anaerobic sludge blanket (UASB) effluent. Water Science and Technology, 72(11), 2034-2044.

19. Bialek, K., Cysneiros, D., O'Flaherty, V. 2014. Hydrolysis, acidification and methanogenesis during low-temperature anaerobic digestion of dilute dairy wastewater in an inverted fluidised bioreactor. Applied Microbiology and Biotechnology, 98(20), 8737-8750.

20. Bohn, I., Björnsson, L., Mattiasson, B. 2007. Effect of temperature decrease on the microbial population and process performance of a mesophilic anaerobic bioreactor. Environmental Technology, 28(8), 943-952.

21. Boon, N., De Windt, W., Verstraete, W., Top, E.M. 2002. Evaluation of nested PCRDGGE (denaturing gradient gel electrophoresis) with group-specific 16S rRNA primers for the analysis of bacterial communities from different wastewater treatment plants. Fems Microbiology Ecology, 39(2), 101-112.

22. Butkovskyi, A., Hernandez Leal, L., Rijnaarts, H.H.M., Zeeman, G. 2015. Fate of pharmaceuticals in full-scale source separated sanitation system. Water Research, 85, 384-392.

23. Chernicharo, C.A.L. 2006. Post-treatment options for the anaerobic treatment of domestic wastewater. Reviews in Environmental Science and Biotechnology, 5(1), 73-92.

24. Chernicharo, C.A.L., Almeida, P.G.S., Lobato, L.C.S., Couto, T.C., Borges, J.M., Lacerda, Y.S. 2009. Experience with the design and start up of two full-scale UASB plants in Brazil: Enhancements and drawbacks, Vol. 60, pp. 507-515.

25. Chernicharo, C.A.L., van Lier, J.B., Noyola, A., Bressani Ribeiro, T. 2015. Anaerobic sewage treatment: state of the art, constraints and challenges. Reviews in Environmental Science and Biotechnology, 14(4), 649-679.

26. Chong, S., Sen, T.K., Kayaalp, A., Ang, H.M. 2012. The performance enhancements of upflow anaerobic sludge blanket (UASB) reactors for domestic sludge treatment - A State-of-the-art review. Water Research, 46(11), 3434-3470.

27. Chu, L.B., Yang, F.L., Zhang, X.W. 2005. Anaerobic treatment of domestic wastewater in a membrane-coupled expended granular sludge bed (EGSB) reactor under moderate to low temperature. Process Biochemistry, 40(3-4), 1063-1070.

28. Connaughton, S., Collins, G., O'Flaherty, V. 2006. Development of microbial community structure and actvity in a high-rate anaerobic bioreactor at $18^{\circ} \mathrm{C}$. Water Research, 40(5), 1009-1017.

29. Cookney, J., Cartmell, E., Jefferson, B., McAdam, E.J. 2012. Recovery of methane 
from anaerobic process effluent using poly-di-methyl-siloxane membrane contactors. Water Science and Technology, 65(4), 604-610.

30. Cuddihy, J., Kennedy, C., Byer, P. 2005. Energy use in Canada: Environmental impacts and opportunities in relationship to infrastructure systems. Canadian Journal of Civil Engineering, 32(1), 1-15.

31. Cysneiros, D., Thuillier, A., Villemont, R., Littlestone, A., Mahony, T., O'Flaherty, V. 2011. Temperature effects on the trophic stages of perennial rye grass anaerobic digestion. Water Science and Technology, 64(1), 70-76.

32. Da Silva, F.J.A., Lima, M.G.S., Mendonça, L.A.R., Gomes, M.J.T.L. 2013. Septic tank combined with Anaerobic filter and conventional UASB - Results from full scale plants. Brazilian Journal of Chemical Engineering, 30(1), 133-140.

33. De-Bashan, L.E., Bashan, Y. 2004. Recent advances in removing phosphorus from wastewater and its future use as fertilizer (1997-2003). Water Research, 38(19), 4222-4246.

34. De Almeida, P.G.S., Chernicharo, C.A.L., Souza, C.L. 2009. Development of compact UASB/trickling filter systems for treating domestic wastewater in small communities in Brazil. in: Water Science and Technology, Vol. 59, pp. 1431-1439.

35. De Sousa, J.T., Foresti, E. 1996. Domestic sewage treatment in an upflow anaerobic sludge blanket - Sequencing batch reactor system. in: Proceedings of the 1995 International Technology Transfer Symposium on High-Performance LowCost Environmental and Sanitation Control Systems, Vol. 33. Bahia, Braz, pp. 7384.

36. De Vries, G.E., Lopez, A. 2013. Wastewaters are not wastes. in: Living with Water: Targeting Quality in a Dynamic World, Springer New York, pp. 101-141.

37. Demirel, B., Scherer, P. 2008. The roles of acetotrophic and hydrogenotrophic methanogens during anaerobic conversion of biomass to methane: A review. Reviews in Environmental Science and Biotechnology, 7(2), 173-190.

38. Deng, L.W., Zheng, P., Chen, Z.A. 2006. Anaerobic digestion and post-treatment of swine wastewater using IC-SBR process with bypass of raw wastewater. Process Biochemistry, 41(4), 965-969.

39. Desloover, J., De Vrieze, J., de Vijver, M.V., Mortelmans, J., Rozendal, R., Rabaey, K. 2015. Electrochemical Nutrient Recovery Enables Ammonia Toxicity Control and Biogas Desulfurization in Anaerobic Digestion. Environmental Science \& Technology, 49(2), 948-955.

40. Drenkova-Tuhtan, A., Meyer, C., Schneider, M., Mandel, K., Gellermann, C., Franzreb, M., Steinmetz, H. 2016. Application of magnetic microsorbents for seperation, concentration and recovery of phosphate from wastewater streams. in: The 13th IWA Leading Edge Conference on Water and wastewater Technologies Jerez de la Frontera, Spain.

41. Duran, M., Tepe, N. 2004. Co-digestion with waste activated sludge for improved methanogenesis from high solids industrial waste. Environmental Technology, 25(8), 919-927.

42. El-Mashad, H.M., Zeeman, G., Van Loon, W.K.P., Bot, G.P.A., Lettinga, G. 2004. Effect of temperature and temperature fluctuation on thermophilic anaerobic 
digestion of cattle manure. Bioresource Technology, 95(2), 191-201.

43. Elmitwalli, T.A., Oahn, K.L.T., Zeeman, G., Lettinga, G. 2002a. Treatment of domestic sewage in a two-step anaerobic filter/anaerobic hybrid system at low temperature. Water Research, 36(9), 2225-2232.

44. Elmitwalli, T.A., Sklyar, V., Zeeman, G., Lettinga, G. 2002b. Low temperature pretreatment of domestic sewage in an anaerobic hybrid or an anaerobic filter reactor. Bioresource Technology, 82(3), 233-239.

45. EPA. 2006. Wastewater Management Fact Sheet, Energy Conservation. U.S. Environmental Protection Agency. EPA 832-F-06-024.

46. Fang, H.H.P., Chung, D.W.C. 1999. Anaerobic treatment of proteinaceous wastewater under mesophilic and thermophilic conditions. Trans. R. Turkish Nat. Committee on Water Pollution, Control, Q. International Association on Water. in: Proceedings of the 1998 4th International Symposium on Waste Management Problems in Agro-Industries, Vol. 40, Elsevier Science Ltd. Exeter, United Kingdom Istanbul, Turkey, pp. 77-84.

47. Faust, L., Temmink, H., Zwijnenburg, A., Kemperman, A.J.B., Rijnaarts, H.H.M. 2014. High loaded MBRs for organic matter recovery fromsewage: Effect of solids retention time on bioflocculation and on the role of extracellular polymers. Water Research, 56, 258-266.

48. Fey, A., Conrad, R. 2000. Effect of temperature on carbon and electron flow and on the archaeal community in methanogenic rice field soil. Applied and Environmental Microbiology, 66(11), 4790-4797.

49. Florencio, L., Takayuki Kato, M., Cardoso De Morais, J. 2001. Domestic sewage treatment in full-scale UASBB plant at Mangueira, Recife, Pernambuco. in: Water Science and Technology, Vol. 44, pp. 71-77.

50. Fukuzaki, S., Nishio, N., Nagai, S. 1990. Kinetics of the methanogenic fermentation of acetate. Applied and Environmental Microbiology, 56(10), 31583163.

51. Gao, W.J., Leung, K.T., Qin, W.S., Liao, B.Q. 2011. Effects of temperature and temperature shock on the performance and microbial community structure of a submerged anaerobic membrane bioreactor. Bioresource Technology, 102(19), 8733-8740.

52. Garcia-Calderon, D., Buffiere, P., Moletta, R., Elmaleh, S. 1998. Anaerobic digestion of wine distillery wastewater in down-flow fluidized bed. Water Research, 32(12), 3593-3600.

53. Garrote, L., Granados, A., Iglesias, A. 2016. Strategies to reduce water stress in Euro-Mediterranean river basins. Science of the Total Environment, 543, 997-1009.

54. Goel, R., Mino, T., Satoh, H., Matsuo, T. 1998. Enzyme activities under anaerobic and aerobic conditions in activated sludge sequencing batch reactor. Water Research, 32(7), 2081-2088.

55. Gomec, C.Y. 2010. High-rate anaerobic treatment of domestic wastewater at ambient operating temperatures: A review on benefits and drawbacks. Journal of Environmental Science and Health - Part A Toxic/Hazardous Substances and Environmental Engineering, 45(10), 1169-1184. 
56. Gouveia, J., Plaza, F., Garralon, G., Fdz-Polanco, F., Peña, M. 2015. Long-term operation of a pilot scale anaerobic membrane bioreactor (AnMBR) for the treatment of municipal wastewater under psychrophilic conditions. Bioresource Technology, 185, 225-233.

57. Guest, J.S., Skerlos, S.J., Barnard, J.L., Beck, M.B., Daigger, G.T., Hilger, H., Jackson, S.J., Karvazy, K., Kelly, L., Macpherson, L., Mihelcic, J.R., Pramanik, A., Raskin, L., Van Loosdrecht, M.C.M., Yeh, D., Love, N.G. 2009. A new planning and design paradigm to achieve sustainable resource recovery from wastewater. Environmental Science and Technology, 43(16), 6126-6130.

58. Hülsen, T., Barry, E.M., Lu, Y., Puyol, D., Batstone, D.J. 2016. Low temperature treatment of domestic wastewater by purple phototrophic bacteria: Performance, activity, and community. Water Research, 100, 537-545.

59. Hahn, M.J., Figueroa, L.A. 2015. Pilot scale application of anaerobic baffled reactor for biologically enhanced primary treatment of raw municipal wastewater. Water Research, 87, 494-502.

60. Halalsheh, M., Sawajneh, Z., Zu'bi, M., Zeeman, G., Lier, J., Fayyad, M., Lettinga, G. 2005. Treatment of strong domestic sewage in a $96 \mathrm{~m} 3$ UASB reactor operated at ambient temperatures: Two-stage versus single-stage reactor. Bioresource Technology, 96(5), 577-585.

61. Hatamoto, M., Yamamoto, H., Kindaichi, T., Ozaki, N., Ohashi, A. 2010. Biological oxidation of dissolved methane in effluents from anaerobic reactors using a down-flow hanging sponge reactor. Water Research, 44(5), 1409-1418.

62. Hendrickx, T.L.G., Wang, Y., Kampman, C., Zeeman, G., Temmink, H., Buisman, C.J.N. 2012. Autotrophic nitrogen removal from low strength waste water at low temperature. Water Research, 46(7), 2187-2193.

63. Hendriks, A.T.W.M., Zeeman, G. 2008. Pretreatments to enhance the digestibility of lignocellulosic biomass. Bioresource Technology, 100(1), 10-18.

64. Hernández-Leal, L., Temmink, H., Zeeman, G., Buisman, C.J.N. 2011. Removal of micropollutants from aerobically treated grey water via ozone and activated carbon. Water Research, 45(9), 2887-2896.

65. Ho, J., Sung, S. 2009. Anaerobic membrane bioreactor treatment of synthetic municipal wastewater at ambient temperature. Water Environment Research, 81(9), 922-928.

66. Ho, J., Sung, S. 2010. Methanogenic activities in anaerobic membrane bioreactors (AnMBR) treating synthetic municipal wastewater. Bioresource Technology, 101(7), 2191-2196.

67. Hulshoff Pol, L., Lettinga, G. 1986. New technologies for anaerobic wastewater treatment. Anaerob Treat in Trop Countries, Proc of an IAWPRC Int Semin, 18(12), 41-53.

68. Kampman, C., Hendrickx, T.L.G., Luesken, F.A., van Alen, T.A., Op den Camp, H.J.M., Jetten, M.S.M., Zeeman, G., Buisman, C.J.N., Temmink, H. 2012. Enrichment of denitrifying methanotrophic bacteria for application after direct low-temperature anaerobic sewage treatment. Journal of Hazardous materials, 227-228, 164-171. 
69. Kassab, G., Halalsheh, M., Klapwijk, A., Fayyad, M., van Lier, J.B. 2010. Sequential anaerobic-aerobic treatment for domestic wastewater - A review. Bioresource Technology, 101(10), 3299-3310.

70. Kettunen, R.H., Rintala, J.A. 1997a. The effect of low temperature $\left(5-29^{\circ} \mathrm{C}\right)$ and adaptation on the methanogenic activity of biomass. Applied Microbiology and Biotechnology, 48(4), 570-576.

71. Kettunen, R.H., Rintala, J.A. 1997b. The effect of low temperature (5-29 degrees C) and adaptation on the methanogenic activity of biomass. Applied Microbiology and Biotechnology, 48(4), 570-576.

72. Langenhoff, A.A.M., Stuckey, D.C. 2000. Treatment of dilute wastewater using an anaerobic baffled reactor: Effect of low temperature. Water Research, 34(15), 3867-3875.

73. Lau, I.W.C., Fang, H.H.P. 1997. Effect of temperature shock to thermophilic granules. Water Research, 31(10), 2626-2632.

74. Laureni, M., Falås, P., Robin, O., Wick, A., Weissbrodt, D.G., Nielsen, J.L., Ternes, T.A., Morgenroth, E., Joss, A. 2016. Mainstream partial nitritation and anammox: Long-term process stability and effluent quality at low temperatures. Water Research, 101, 628-639.

75. LeitÃ£o, R.C., Van Haandel, A.C., Zeeman, G., Lettinga, G. 2006. The effects of operational and environmental variations on anaerobic wastewater treatment systems: A review. Bioresource Technology, 97(9), 1105-1118.

76. Lettinga, G. 1995. Anaerobic digestion and wastewater treatment systems. Antonie van Leeuwenhoek, 67(1), 3-28.

77. Lettinga, G., De Man, A., Van der Last, A.R.M., Wiegant, W., Van Knippenberg, K., Frijns, J., Van Buuren, J.C.L. 1993. Anaerobic treatment of domestic sewage and wastewater. Proceedings of the IAWPRC first Middle East Conference, 27(9), 67-73.

78. Lettinga, G., Field, J., Van Lier, J., Zeeman, G., Hulshoff Pol, L.W. 1997. Advanced anaerobic wastewater treatment in the near future. in: Proceedings of the 1996 IAWQ International Conference on Advanced Wastewater Treatment: Nutrient Removal and Anaerobic Processes, AQUATECH'96, Vol. 35, Elsevier Science Ltd. Oxford, United Kingdom, Amsterdam, Neth, pp. 5-12.

79. Lettinga, G., Rebac, S., Parshina, S., Nozhevnikova, A., Van Lier, J.B., Stams, A.J.M. 1999. High-rate anaerobic treatment of wastewater at low temperatures. Applied and Environmental Microbiology, 65(4), 1696-1702.

80. Lettinga, G., Rebac, S., Zeeman, G. 2001. Challenge of psychrophilic anaerobic wastewater treatment. Trends in Biotechnology, 19(9), 363-370.

81. Levenspiel, O. 2013. Chemical Reactor Omnibook Lulu.com, corvallis, Oregon.

82. Li, Y., Park, S.Y., Zhu, J. 2011. Solid-state anaerobic digestion for methane production from organic waste. Renewable and Sustainable Energy Reviews, 15(1), 821-826.

83. Liao, B.Q., Kraemer, J.T., Bagley, D.M. 2006. Anaerobic membrane bioreactors: Applications and research directions. Critical Reviews in Environmental Science and Technology, 36(6), 489-530. 
84. Lier, J.B.v., Mahmoud, N., Zeeman, G. 2008. Anaerobic biological wastewater treatment. Chapter 16. In Biological Wastewater Treatment; Principles, Modelling and Design. IWA publishing.

85. Lokshina, L.Y., Vavilin, V.A., Kettunen, R.H., Rintala, J.A., Holliger, C., Nozhevnikova, A.N. 2001. Evaluation of kinetic coefficients using integrated monod and haldane models for low-temperature acetoclastic methanogenesis. Water Research, 35(12), 2913-2922.

86. Lotti, T., Kleerebezem, R., Hu, Z., Kartal, B., De Kreuk, M.K., Van Erp Taalman Kip, C., Kruit, J., Hendrickx, T.L.G., Van Loosdrecht, M.C.M. 2015. Pilot-scale evaluation of anammox-based mainstream nitrogen removal from municipal wastewater. Environmental Technology (United Kingdom), 36(9), 1167-1177.

87. Lowe, K.S., Siegrist, R.L. 2008. Controlled field experiment for performance evaluation of septic tank effluent treatment during soil infiltration. Journal of Environmental Engineering, 134(2), 93-101.

88. Luostarinen, S., Sanders, W., Kujawa-Roeleveld, K., Zeeman, G. 2007. Effect of temperature on anaerobic treatment of black water in UASB-septic tank systems. Bioresource Technology, 98(5), 980-986.

89. Luostarinen, S.A., Rintala, J.A. 2005. Anaerobic on-site treatment of black water and dairy parlour wastewater in UASB-septic tanks at low temperatures. Water Research, 39(2-3), 436-448.

90. Mahmoud, N. 2008. High strength sewage treatment in a UASB reactor and an integrated UASB-digester system. Bioresource Technology, 99(16), 7531-7538.

91. Mahmoud, N., Zeeman, G., Gijzen, H., Lettinga, G. 2004. Anaerobic sewage treatment in a one-stage UASB reactor and a combined UASB-Digester system. Water Research, 38(9), 2347-2357.

92. Mahmoud, N., Zeeman, G., van Lier, J.B. 2008. Adapting UASB technology for sewage treatment in Palestine and Jordan. in: Water Science and Technology, Vol. 57, pp. 361-366.

93. Manariotis, I.D., Grigoropoulos, S.G. 2002. Low-strength wastewater treatment using an anaerobic baffled reactor. Water Environment Research, 74(2), 170-176.

94. Mara, D. 1987. WASTE STABILIZATION PONDS: PROBLEMS AND CONTROVERSIES. Water Quality International(1), 20-22.

95. Martinez-Sosa, D., Helmreich, B., Netter, T., Paris, S., Bischof, F., Horn, H. 2011. Anaerobic submerged membrane bioreactor (AnSMBR) for municipal wastewater treatment under mesophilic and psychrophilic temperature conditions. Bioresource Technology, 102(22), 10377-10385.

96. Matsuura, N., Hatamoto, M., Sumino, H., Syutsubo, K., Yamaguchi, T., Ohashi, A. 2015. Recovery and biological oxidation of dissolved methane in effluent from UASB treatment of municipal sewage using a two-stage closed downflow hanging sponge system. Journal of Environmental Management, 151, 200-209.

97. McCarty, P.L., Bae, J., Kim, J. 2011. Domestic wastewater treatment as a net energy producer-can this be achieved? Environmental Science and Technology, 45(17), 7100-7106.

98. McKeown, R.M., Hughes, D., Collins, G., Mahony, T., O'Flaherty, V. 2012. Low- 
temperature anaerobic digestion for wastewater treatment. Current Opinion in Biotechnology, 23(3), 444-451.

99. McKeown, R.M., Scully, C., Enright, A.M., Chinalia, F.A., Lee, C., Mahony, T., Collins, G., O'Flaherty, V. 2009a. Psychrophilic methanogenic community development during long-term cultivation of anaerobic granular biofilms. ISME Journal, 3(11), 1231-1242.

100.McKeown, R.M., Scully, C., Mahony, T., Collins, G., O'Flaherty, V. 2009b. Longterm (1243 days), low-temperature $\left(4-15^{\circ} \mathrm{C}\right)$, anaerobic biotreatment of acidified wastewaters: Bioprocess performance and physiological characteristics. Water Research, 43(6), 1611-1620.

101.Miqueleto, A.P., Dolosic, C.C., Pozzi, E., Foresti, E., Zaiat, M. 2010. Influence of carbon sources and $\mathrm{C} / \mathrm{N}$ ratio on EPS production in anaerobic sequencing batch biofilm reactors for wastewater treatment. Bioresource Technology, 101(4), 13241330 .

102.Miqueleto, A.P., Rodrigues, J.A.D., Ratusznei, S.M., Foresti, E., Zaiat, M. 2005. Treatment of easily degradable wastewater in a stirred anaerobic sequencing batch biofilm reactor. Water Research, 39(11), 2376-2384.

103.Monroy, O., Famá, G., Meraz, M., Montoya, L., MacArie, H. 2000. Anaerobic digestion for wastewater treatment in Mexico: State of the technology. Water Research, 34(6), 1803-1816.

104.Mungray, A.K., Patel, K. 2011. Coliforms removal in two UASB + ASP based systems. International Biodeterioration and Biodegradation, 65(1), 23-28.

105.Muyzer, G., Dewaal, E.C., Uitterlinden, A.G. 1993. PROFILING OF COMPLEX MICROBIAL-POPULATIONS BY DENATURING GRADIENT GELELECTROPHORESIS ANALYSIS OF POLYMERASE CHAIN REACTIONAMPLIFIED GENES-CODING FOR 16S RIBOSOMAL-RNA. Applied and Environmental Microbiology, 59(3), 695-700.

106.Nada, T., Moawad, A., El-Gohary, F.A., Farid, M.N. 2011. Full-scale municipal wastewater treatment by up-flow anaerobic sludge blanket UASB) in Egypt. Desalination and Water Treatment, 30(1-3), 134-145.

107.Noyola, A., Capdeville, B., Roques, H. 1988. Anaerobic treatment of domestic sewage with a rotating stationary fixed-film reactor. Water Research, 22(12), 15851592.

108.Noyola, A., Padilla-Rivera, A., Morgan-Sagastume, J.M., Güereca, L.P., Hernández-Padilla, F. 2012. Typology of Municipal Wastewater Treatment Technologies in Latin America. Clean - Soil, Air, Water, 40(9), 926-932.

109.O'Reilly, J., Lee, C., Collins, G., Chinalia, F., Mahony, T., O'Flaherty, V. 2009. Quantitative and qualitative analysis of methanogenic communities in mesophilically and psychrophilically cultivated anaerobic granular biofilims. Water Research, 43(14), 3365-3374.

110.Oliveira, S.C., von Sperling, M. 2011. Performance evaluation of different wastewater treatment technologies operating in a developing country. Journal of Water Sanitation and Hygiene for Development, 1(1), 37-56.

111.Owen, W.F. 1982. Energy in Wastewater Treatment. Prentice-Hall, Inc., Englewood 
Cliffs, NJ.

112.Ozgun, H., Tao, Y., Ersahin, M.E., Zhou, Z., Gimenez, J.B., Spanjers, H., van Lier, J.B. 2015. Impact of temperature on feed-flow characteristics and filtration performance of an upflow anaerobic sludge blanket coupled ultrafiltration membrane treating municipal wastewater. Water Research, 83, 71-83.

113.Parsons, S.A., Smith, J.A. 2008. Phosphorus removal and recovery from municipal wastewaters. Elements, 4(2), 109-112.

114.Pavlostathis, S.G., Giraldo-Gomez, E. 1991a. Kinetics of anaerobic treatment. Water Science and Technology, 24(8), 35-59.

115.Pavlostathis, S.G., Giraldo-Gomez, E. 1991b. Kinetics of anaerobic treatment: A critical review. Critical Reviews in Environmental Control, 21(5-6), 411-490.

116.Peña, M.R., Rodriguéz, J., Mara, D.D., Sepulveda, M. 2000. UASBs or anaerobic ponds in warm climates? A preliminary answer from Colombia. in: 4th International Specialist Conference on Waste Stabilization Ponds: Technology and the Environment, Vol. 42, Int Water Assoc. United Kingdom

117.Marrakech, Morocco, pp. 59-65.

118.Pereboom, J.H.F. 1994. Size distribution model for methanogenic granules from full scale UASB and IC reactors. Proceedings of the IAWQ 7th International Symposium on Anaerobic Digestion, 30(12), 211-221.

119.Pereboom, J.H.F., Vereijken, T.L.F.M. 1994. Methanogenic granule development in full scale internal circulation reactors. Proceedings of the 17th Biennial Conference of the International Association on Water Quality. Part 8, 30(8 pt 8), 9-21.

120.Polito Braga, C.M., von Sperling, M., Braga, A.R., Pena, R.T. 2005. Control strategies for a combined anaerobic (UASB) - Aerobic (activated sludge) wastewater treatment system. Environmental Technology, 26(12), 1393-1401.

121.Rebac, S., Gerbens, S., Lens, P., Van Lier, J.B., Stams, A.J.M., Keesman, K.J., Lettinga, G. 1999a. Kinetics of fatty acid degradation by psychrophilically grown anaerobic granular sludge. Bioresource Technology, 69(3), 241-248.

122.Rebac, S., Ruskova, J., Gerbens, S., van Lier, J.B., Stams, A.J.M., Lettinga, G. 1995. High-rate anaerobic treatment of wastewater under psychrophilic conditions. Journal of Fermentation and Bioengineering, 80(5), 499-506.

123.Rebac, S., Van Lier, J.B., Lens, P., Stams, A.J.M., Dekkers, F., Swinkels, K.T.M., Lettinga, G. 1999b. Psychrophilic anaerobic treatment of low strength wastewaters. Water Science and Technology, 39(5), 203-210.

124.Rebac, S., Van Lier, J.B., Lens, P., Stams, A.J.M., Dekkers, F., Swinkels, K.T.M., Lettinga, G. 1999c. Psychrophilic anaerobic treatment of low strength wastewaters. in: Proceedings of the 1998 International Congress on Options for Closed Water Systems - Sustainable Water Management, Vol. 39. Wageningen, NLD, pp. 203210.

125.Resende, J.A., Godon, J.J., Bonnafous, A., Arcuri, P.B., Silva, V.L., Otenio, M.H., Diniz, C.G. 2015. Seasonal Variation on Microbial Community and Methane Production during Anaerobic Digestion of Cattle Manure in Brazil. Microbial Ecology. 
126.Rijsberman, F.R. 2006. Water scarcity: Fact or fiction? Agricultural Water Management, 80(1-3 SPEC. ISS.), 5-22.

127.Rosa, A.P., Lobato, L.C.S., Chernicharo, C.A.L., Martins, D.C.R.B., Maciel, F.M., Borges, J.M. 2012. Improving performance and operational control of UASB reactors via proper sludge and scum discharge routines. Water Practice and Technology, 7(3).

128.Saha, S., Badhe, N., De Vrieze, J., Biswas, R., Nandy, T. 2015. Methanol induces low temperature resilient methanogens and improves methane generation from domestic wastewater at low to moderate temperatures. Bioresource Technology, 189, 370-378.

129.Sanders, W.T.M., Geerink, M., Zeeman, G., Lettinga, G. 2000. Anaerobic hydrolysis kinetics of particulate substrates. Water Science and Technology, 41(8), 115-122.

130.Schellinkhout, A., Collazos, C.J. 1992. Full-scale application of the UASB technology for sewage treatment. Proceedings of the 6th International Symposium on Anaerobic Digestion, 25(7), 159-166.

131.Scherson, Y.D., Criddle, C.S. 2014. Recovery of freshwater from wastewater: Upgrading process configurations to maximize energy recovery and minimize residuals. Environmental Science and Technology, 48(15), 8420-8432.

132.Schwarz, W.H. 2001. The cellulosome and cellulose degradation by anaerobic bacteria. Applied Microbiology and Biotechnology, 56(5-6), 634-649.

133.Seghezzo, L., Cuevas, C.M., Trupiano, A.P., Guerra, R.G., González, S.M., Zeeman, G., Lettinga, G. 2006. Stability and activity of anaerobic sludge from UASB reactors treating sewage in subtropical regions. in: Water Science and Technology, Vol. 54, pp. 223-229.

134.Seghezzo, L., Zeeman, G., Van Lier, J.B., Hamelers, H.V.M., Lettinga, G. 1998. A review: The anaerobic treatment of sewage in UASB and EGSB reactors. Bioresource Technology, 65(3), 175-190.

135.Şen, S., Demirer, G.N. 2003. Anaerobic treatment of real textile wastewater with a fluidized bed reactor. Water Research, 37(8), 1868-1878.

136.Shiklomanov, I.A. 2000. Appraisal and assessment of world water resources. Water International, 25(1), 11-32.

137.Siegrist, H., Salzgeber, D., Eugster, J., Joss, A. 2008. Anammox brings WWTP closer to energy autarky due to increased biogas production and reduced aeration energy for N-removal. in: Water Science and Technology, Vol. 57, pp. 383-388.

138.Singh, K.S., Viraraghavan, T. 2003. Impact of temperature on performance, microbiological, and hydrodynamic aspects of UASB reactors treating municipal wastewater. in: Water Science and Technology, Vol. 48, pp. 211-217.

139.Singh, K.S., Viraraghavan, T. 2000. Performance of UASB reactors at 6 to $32^{\circ} \mathrm{C}$ in municipal wastewater treatment. Water Quality Research Journal of Canada, 35(1), 113-124.

140.Smith, A.L., Skerlos, S.J., Raskin, L. 2013. Psychrophilic anaerobic membrane bioreactor treatment of domestic wastewater. Water Research, 47(4), 1655-1665.

141.Souza, C.L., Chernicharo, C.A.L., Aquino, S.F. 2011. Quantification of dissolved 
methane in UASB reactors treating domestic wastewater under different operating conditions. Water Science and Technology, 64(11), 2259-2264.

142.Speece, R.E. 2008. Anaerobic Biotechnology and Odor/Corrosion Control for Municipalities and Industries. Archae Press, Nashville.

143.Sperling, M.v., Chernicharo, C.A.d.L. 2005. Biological Wastewater Treatment in Warm Climate Regions. IWA Publishing, Alliance House, 12 Caxton Street, London SW1H 0QS, UK.

144.Springer, N.P., Duchin, F. 2014. Feeding nine billion people sustainably: Conserving land and water through shifting diets and changes in technologies. Environmental Science and Technology, 48(8), 4444-4451.

145.Switzenbaum, M.S., Jewell, W.J. 1980. Anaerobic attached-film expanded-bed reactor treatment. Journal of the Water Pollution Control Federation, 52(7), 19531965.

146.Tawfik, A., Zeeman, G., Klapwijk, A., Sanders, W., El-Gohary, F., Lettinga, G. 2003. Treatment of domestic sewage in a combined UASB/RBC system. Process optimization for irrigation purposes. in: Water Science and Technology, Vol. 48, pp. 131-138.

147.Torres, P., Foresti, E. 2001. Domestic sewage treatment in a pilot system composed of UASB and SBR reactors. in: Water Science and Technology, Vol. 44, pp. 247253.

148.Uemura, S., Harada, H. 2000. Treatment of sewage by a UASB reactor under moderate to low temperature conditions. Bioresource Technology, 72(3), 275-282.

149.UVW. 2006. Landelijke bedrijfsvergelijking van de waterschappen over het zuiveringsbeheer, In Dutch: Zuiver Afvalwater, pp. available from: http://www.uvw.nl/TRIBAL tsNews/atts/1659bvz rapport def.pdf.

150.van den Brink, P., Satpradit, O.A., van Bentem, A., Zwijnenburg, A., Temmink, H., van Loosdrecht, M. 2011. Effect of temperature shocks on membrane fouling in membrane bioreactors. Water Research, 45(15), 4491-4500.

151.Van der Last, A.R.M., Lettinga, G. 1992. Anaerobic treatment of domestic sewage under moderate climatic (Dutch) conditions using upflow reactors at increased superficial velocities. Proceedings of the 6th International Symposium on Anaerobic Digestion, 25(7), 167-178.

152.Van Lier, J.B., Rebac, S., Lettinga, G. 1997. High-rate anaerobic wastewater treatment under psychrophilic and thermophilic conditions. in: Water Science and Technology, Vol. 35, Elsevier Science Ltd. Oxford, United Kingdom

153.Amsterdam, Neth, pp. 199-206.

154.van Lier, J.B., van der Zee, F.P., Frijters, C.T.M.J., Ersahin, M.E. 2015. Celebrating 40 years anaerobic sludge bed reactors for industrial wastewater treatment. Reviews in Environmental Science and Biotechnology, 14(4), 681-702.

155.Vavilin, V.A., Fernandez, B., Palatsi, J., Flotats, X. 2008. Hydrolysis kinetics in anaerobic degradation of particulate organic material: An overview. Waste Management, 28(6), 939-951.

156.Vavilin, V.A., Rytov, S.V., Lokshina, L.Y. 1996. A description of hydrolysis kinetics in anaerobic degradation of particulate organic matter. Bioresource Technology, 
56(2-3), 229-237.

157.Veeken, A., Hamelers, B. 1999. Effect of temperature on hydrolysis rates of selected biowaste components. Bioresource Technology, 69(3), 249-254.

158.Verstraete, W., Van de Caveye, P., Diamantis, V. 2009. Maximum use of resources present in domestic "used water". Bioresource Technology, 100(23), 5537-5545.

159.Verstraete, W., Vandevivere, P. 1999. New and broader applications of anaerobic digestion. Critical Reviews in Environmental Science and Technology, 29(2), 151173.

160.Vilchez-Vargas, R., Geffers, R., Suarez-Diez, M., Conte, I., Waliczek, A., Kaser, V.S., Kralova, M., Junca, H., Pieper, D.H. 2013. Analysis of the microbial gene landscape and transcriptome for aromatic pollutants and alkane degradation using a novel internally calibrated microarray system. Environmental Microbiology, 15(4), 1016-1039.

161.Walia, R., Kumar, P., Mehrotra, I. 2011. Performance of UASB based sewage treatment plant in India: Polishing by diffusers an alternative. Water Science and Technology, 63(4), 680-688.

162.Yamamoto, S., Alcauskas, J.B., Crozier, T.E. 1976. SOLUBILITY OF METHANE IN DISTILLED WATER AND SEAWATER. Journal of Chemical and Engineering Data, 21(1), 78-80.

163.Yasui, H., Goel, R., Li, Y.Y., Noike, T. 2008. Modified ADM1 structure for modelling municipal primary sludge hydrolysis. Water Research, 42(1-2), 249-259.

164.Yaya-Beas, R.E., Cadillo-La-Torre, E.A., Kujawa-Roeleveld, K., van Lier, J.B., Zeeman, G. 2016. Presence of helminth eggs in domestic wastewater and its removal at low temperature UASB reactors in Peruvian highlands. Water Research, 90, 286-293.

165.Young, J.C., McCarty, P.L. 1969. The anaerobic filter for waste treatment. Journal of the Water Pollution Control Federation, 41.

166.Zeeman, G. 1991a. Mesophilic and psychrophilic digestion of liquid manure, Wageningen University. the Netherlands.

167.Zeeman, G. 1991b. Mesophilic and psychrophilic digestion of liquid manure. in: Department of Environmental Technology, Vol. PhD., Wageningen University. the Netherlands.

168.Zeeman, G. 1994. Methane production/emission in storages for animal manure. Fertilizer Research, 37(3), 207-211.

169.Zeeman, G., Kujawa-Roeleveld, K. 2011. Resource recovery from source separated domestic waste(water) streams; full scale results. Water Science and Technology, 64(10), 1987-1992.

170.Zeeman, G., Sanders, W.T.M., Wang, K.Y., Lettinga, G. 1997. Anaerobic treatment of complex wastewater and waste activated sludge - Application of an upflow anaerobic solid removal (UASR) reactor for the removal and pre-hydrolysis of suspended COD. Water Science and Technology, 35, 121-128.

171.Zeng, Z., Liu, J., Koeneman, P.H., Zarate, E., Hoekstra, A.Y. 2012. Assessing water footprint at river basin level: A case study for the Heihe River Basin in northwest China. Hydrology and Earth System Sciences, 16(8), 2771-2781. 
172.Zhang, L., Gao, R., Naka, A., Hendrickx, T.L.G., Rijnaarts, H.H.M., Zeeman, G. 2016a. Hydrolysis rate constants at $10-25^{\circ} \mathrm{C}$ can be more than doubled by a short anaerobic pre-hydrolysis at $35^{\circ} \mathrm{C}$. Water Research, 104, 283-291.

173.Zhang, L., Hendrickx, T.L.G., Kampman, C., Temmink, H., Zeeman, G. 2013. Codigestion to support low temperature anaerobic pretreatment of municipal sewage in a UASB-digester. Bioresource Technology, 148, 560-566.

174.Zhang, L., Hendrickx, T.L.G., Kampman, C., Zeeman, G., Temmink, H., Li, W., Buisman, C.J.N. 2012. The effect of sludge recirculation rate on a UASB-digester treating domestic sewage at $15{ }^{\circ} \mathrm{C}$. Water Science and Technology, 66(12), 25972603.

175.Zhang, L., Vrieze, J.D., Hendrickx, T.L.G., Wei, W., Temmink, H., Rijnaarts, H., Zeeman, G. 2016b. Anaerobic treatment of domestic wastewater in a UASBdigester demonstrated at a temperature of $10^{\circ} \mathrm{C}$. not published.

176.Zhang L., Hendrickx, T.L.G., Kampman, C., Zeeman, G., Temmink, B.G., Weiguang Li, Buisman, C.J.N. 2011. The effect of sludge recirculation rate on a UASB-digester treating domestic sewage at $15{ }^{\circ} \mathrm{C}$. in: X latin American Workshop and Symposium on Anaerobic Digestion. Brazil.

177.Zhang, Y., Zhang, J., Tang, G., Chen, M., Wang, L. 2016c. Virtual water flows in the international trade of agricultural products of China. Science of the Total Environment, 557-558, 1-11.

178.Zhou, Y., Khu, S.T., Xi, B., Su, J., Hao, F., Wu, J., Huo, S. 2014. Status and challenges of water pollution problems in China: Learning from the European experience. Environmental Earth Sciences, 72(4), 1243-1254.

179.Zinia, N.J., Kroeze, C. 2015. Future trends in urbanization and coastal water pollution in the Bay of Bengal: the lived experience. Environment, Development and Sustainability, 17(3), 531-546. 
Annex 


\section{Annex 1 Quality control of the parameters for real-time PCR analysis}

Table 1 gives quality control of the parameters for real-time PCR analysis. These parameters were obtained during analysis with the StepOnePlus V2.3 software. The detection limit was calculated as copies of the target 16S rRNA gene fragment per gram wet sludge, and was determined taking both dilution and extraction efficiency into account.

Table 1 Quality control of the parameters for real-time PCR analysis.

\begin{tabular}{ccccc}
\hline Parameter & Slope & $\mathrm{R}^{2}$ & Efficiency $(\%)$ & Detection limit (copies g-1) \\
\hline Methanosaetaceae & -3.7 & 0.99 & 85 & $1.53 \times 10^{4}$ \\
Methanosarcinaceae & -4.6 & 1.00 & 64 & $1.45 \times 10^{4}$ \\
Methanobacteriales & -4.1 & 1.00 & 75 & $1.18 \times 10^{4}$ \\
Methanomicrobiales & -4.1 & 1.00 & 76 & $1.08 \times 10^{4}$ \\
Total bacteria & -3.2 & 1.00 & 104 & $2.76 \times 10^{4}$ \\
\hline
\end{tabular}

\section{Annex 2 Effluent VSS concentration and COD suspended $_{\text {concentration }}$}

Table 2 gives effluent VSS concentration and $\mathrm{COD}_{\text {suspended }}$ concentration, and the ratio

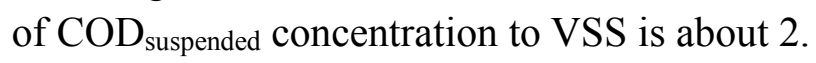

Table 2 Effluent VSS concentration and COD suspended $_{\text {concentration }}$

(sample numbers:8, unit: $\mathrm{mg} / \mathrm{L}$ )

\begin{tabular}{cc}
\hline $\begin{array}{c}\text { Effluent VSS } \\
\text { concentration }\end{array}$ & $\begin{array}{c}\text { Effluent COD } \\
\text { suspended } \\
\text { concentration }\end{array}$ \\
\hline $40 \pm 5$ & $82 \pm 20$ \\
\hline
\end{tabular}




\section{Annex 3 Equations used for assessment of Energy consumption at $10^{\circ} \mathrm{C}$}

Major energy consumption of the UASB-digester system treating low temperature sewage is heating of the sludge that is transferred from the UASB reactor to the digester. The energy consumption depends on the sludge recirculation rate. So far, applying the proof of principle, a high sludge recirculation rate (16\% of influent flow rate) is applied to test the feasibility of the system for the treatment of sewage at $10^{\circ} \mathrm{C}$. The sludge recirculation rate can be decreased after optimization. At present a model is model is developed to predict, making use of the collected data, the optimal sludge recirculation rate.

- Heating consumption

$\Delta$ Temperature $\times$ Specific heat capacity of water $\times$ Sludge recirculation rate

$$
=25 \times 4.2 \times 0.16 \times 1000=16800(\mathrm{KJ} / \mathrm{m} 3 \text { treated sewage })
$$

- Energy production of methane

Based on the COD balance, about $40 \%$ of influent COD can be converted to methane. Given the influent COD concentration of $600 \mathrm{mg} / \mathrm{L}$. Heat production of methane is calculated:

Heating production:

Heat value of methane $\times$ methane production

$=$ Heat value of methane $\times($ influent COD concentration $\times 40 \% \times 0.35)$

$=40 \times(600 \times 40 \% \times 0.35)=3360(\mathrm{KJ} / \mathrm{m} 3$ treated sewage $)$

- Energy balance

Energy balance $=$ energy consumption- energy production $=16800-3360=13440(\mathrm{KJ} /$ $\mathrm{m} 3$ treated sewage)

- Portion of heating energy compensated by methane

$$
\text { Portion }_{\text {methane }}=100 \times \text { Heating }_{\text {methane }} / \text { Heating } \text { consumption }=3360 / 16800=20 \% \text {. }
$$




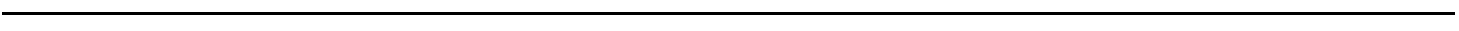




\section{Publications}

- Zhang, L., Hendrickx, T.L.G., Kampman, C., Temmink, H., Zeeman, G. 2013. Co-digestion to support low temperature anaerobic pretreatment of municipal sewage in a UASB-digester. Bioresource Technology, 148, 560-566.

- Zhang, L., Hendrickx, T.L.G., Kampman, C., Zeeman, G., Temmink, H., Li, W., Buisman, C.J.N. 2012. The effect of sludge recirculation rate on a UASB-digester treating domestic sewage at $15^{\circ} \mathrm{C}$. Water Science and Technology, 66(12), 2597-2603.

- Zhang, L., Naka, A., Hendrickx, T.L.G., Zeeman, G., Rijnaarts, H.H.M. 2015. Short anaerobic pre-hydrolysis at $35^{\circ} \mathrm{C}$ more than doubled hydrolysis rate constants at $10^{\circ} \mathrm{C}$. Water research 104, 283-291.

- Dandan Liu, Zhang, L., Si Chen, Annemiek ter Heijne, Cees Buisman. 2015. Bioelectrochemical enhancement of methane production from low temperature anaerobic digestion at $10^{\circ} \mathrm{C}$. Water Research, 99, 281-287.

- Zhang, L., Hendrickx, T.L.G., Zeeman, G., Rijnaarts, H.H.M. Effects of changing temperature on methanogenisis and effects of temperature on affinity of anaerobic floc sludge. in preparation

- Zhang, L., Hendrickx, T.L.G., Zeeman, G., Rijnaarts, H.H.M. Anaerobic treatment of domestic wastewater in a UASB-digester demonstrated at a temperature of $10^{\circ} \mathrm{C}$. summited

\section{Oral presentations:}

- Zhang, L., Hendrickx, T.L.G., Kampman, C., Zeeman, G., Temmink, H., Li W. and Buisman, C.J.N. The effect of sludge recirculation rate on a UASB-digester treating domestic sewage at $15{ }^{\circ} \mathrm{C}$. Conference proceedings of $X$ Latin American Workshop and Symposium on Anaerobic Digestion, Brazil, 2011, October 23-27.

- Hendrickx, T. L.G., Kampman, C., Zhang, L., Zeeman, G., Temmink, H. and Buisman, C. J.N. Energy balance for direct anaerobic waste water treatment. Conference proceedings IWA World Congress on Water Climate and Energy, Dublin, Ireland, 2012, May 13-18.

- Kampman, C., Hendrickx, T.L.G., Zhang, L., et al. Denitrification with dissolved methane from anaerobic wastewater treatment: a novel opportunity for wastewater treatment. Conference proceedings Water and Innovation - Water technology, Amsterdam, The Netherlands, 2011, November 3-4.

- Zhang, L., Hendrickx, T.L.G., Kampman, C., Zeeman, G., Temmink, H., Weiguang L. and Buisman, C.J.N. Sludge transfer point of a UASB-digester system: key to efficient low temperature anaerobic sewage treatment. 13th World Congress on Anaerobic Digestion: Recovering (bio) Resources for the World. Santiago de Compostela, Spain, 2013, June 2528.

- Zhang, L., Hendrickx, T.L.G., Kampman, C., Zeeman, G., Temmink, H. and Buisman, C.J.N. 
Co-digestion: a method to support a UASB-digester for treating low temperature domestic sewage treatment. The Technical Commission Anaerobic processes, Wageningen, The Netherlands, 2013, September 26.

\section{Poster presentation}

- Zhang, L., Li, W., Wang, K. Enhancement of tannery wastewater treatment at low temperature by coagulation coupled with cationic polyacrylamide. International Conference on Energy and Environment Technology, Guilin, China, 2009, October 16-18.

- Zhang, L., Hendrickx, T.L.G., Zeeman, G., Rijnaarts, H.H.M. Applying a UASB-digester for low temperature domestic sewage treatment. Environmental Technology for Impact ETEI2015, The Netherlands, 2015, April 29-30. 
Acknowledgement 
Finally, I am starting to write the last pages of my PhD thesis. At this moment, all the memories related to the study, work and life these years in the Netherlands are like showing movies in my mind. I appreciate all the people providing kind help to me, and I will never come to this step of my PhD study without these great friends.

Difficulties are normal issues involved the PhD study journey, such as leaving from family, technical problems and time difference. Once I thought that I was deeply in the dark and almost lost. Luckily, Grietje and Huub's offered me the great help in the aspects of directing research and proceeding the project. I am proud that I have two professors to be my promotors, which at least shows that I am not too bad.

Firstly, I would like to thank Grietje. You offered me this amazing opportunity to peruse my dream in the research of "anaerobic world". It is the most valuable experience in my life to learn doing research in the department of Environmental technology of Wageningen University. The experience of the $\mathrm{PhD}$ study here is the treasure in my whole life, and I am so lucky to be one of your students. The guidance is a marine lighting for my future career. This opportunity changes my view of doing research, supervising students and attitude to life. From you, I learn how to be critical which is the most difficult thing due to my personality; I learn how to write and think through all the comments into very details for each research article and the thesis. You show me a target of a great scientist to follow and catch in the future. Thank you for your patience, kindness, encourage, and trust for the young scientist like me to grow up.

Huub, really appreciate for your great help. The map of my $\mathrm{PhD}$ study process becomes much clearer when you take part in. I know exactly what a plan for a whole year should be, what the expectation is, and what the contribution to science and companies means through discussion in each meeting. You provide key and effective power to proceed the project, so that I don't need to be frustrated due to the annoying and endless technical problems. You put effort to break the hinder obstacle of communication among people involved in the project. I feel like that I am back to the right path to the research because of your magic power. Now, I don't dare to imagine the $\mathrm{PhD}$ life without your help. Your care for us can be seen everywhere, e.g. you always ask "is everything going well?" and always reply the emails fast no matter how busy you are. We feel more comfortable, confident and would like to contribute more to the research and department due to your strong support. You provide me a target of a great professor to follow as I see your pure focus, effort and achievement in the career.

Tim, I feel lucky that I could start work together with your guidance, otherwise the story ended when I finished the guest researcher contract. I remember the days we talked and discussed about the project. I would have not continued the study without your recommendation and help. Thank you for all the trust and patience. You helped to deal with lots of troubles in my work and life. I can realize, after I supervised some master students, how headache you had when you faced my first several 'draft' papers. The journey that we work together is a treasure for my life.

Hardy, thank you for the great help when I started to work in your project. I still 
remember the awkward moment when we first met. I was so surprised that you knew so much about the project I worked on, and hadn't realized that you were the project manager until you told me. You have many interesting ideas and great suggestions. Your suggestion about the buffer tank almost saved my research life. Besides, your contribution on writing the discussion part and managing the whole paper impressed me.

Thank you for the project committees: Cora, Arne, Piron, Vlot, Marcel, Jeffrey, Frijters, Verhoeven and A.W.A.de Man, thank you for the trust, effort and contribution into my project. Especially for Cora, your communication with me during each meeting makes me feel comfortable. It gives signal that the work is interesting and understandable. I know that we still have much work to do to put it into practice. I will continue the work in my career and I expect to cooperate with you in the close future.

Liesbeth, I appreciate that you always give patient help for many trivial matters for all the people in the department. I will never forget your help for housing, registration and suggestion etc.., when I just arrived in the Netherlands, and all the help related to study, work and life in the Netherlands. Gea, your kind greetings make me feel warm and close, which is so important for people working in a completely different culture apart from family. Katja, thank you very much for introducing me to the world of anaerobic experiments, and your guidance when I felt upset. Harry, Hans, Young, Ilse, else, thank you for the great help for technical support. Nora, the suggestions on my CV help me to open the door of positions abroad. It shows a great example of a good CV and makes me know the difference of $\mathrm{CV}$ in different culture. Pim, your great job provides me a good opportunity to continue my research interest. Vinnie, thank you for the kind help and consideration for all the troubles in the lab. Your support is the guarantee for the good work. Bert, the project can't be finished without your help in practical work. It is a pity that many problems happened.

Many thanks to my colleagues in Wageningen University, so many people are passed by before I really started the $\mathrm{PhD}$ study (2009.09-2011.12) and after I continued the $\mathrm{PhD}$ study from 2013.1. My life and work became hopeful due to the funny friends. Christel, nice to work with you in the same project. Your great work makes our systems promising for the future of wastewater treatment. Mieke, Raph, Tim, and Diego, thank you for the running team members, and we had a lot of fun together. Sharuru and Indra thank you for the guidance for the belief. Annemiek, your thesis is inspiring and the cooperation with you helps a lot. Arnoud, you are funny and always show up to give a hand when I met problems. DanDan, Shokou, Bruna, Justine, Sophie, Kanjana, thank you for the time sharing the same office. Thank all my colleges: Harry, Katarzyna, Alette, Marc, Andrii, Miriam, Leire, Lucia, Rosanne, David, Miram, Engo, Abiodun, Delaram, Koen, Sanne, Samet, Dannie, Mark, Nurul, Livio and Marjo.

Thank all the students I supervised in this project: Yongzhi, Jose, Grace, Binhe, Santtu, Agathi, Rui and Wei. You all contributed a lot to the research and I appreciate to your courage to challenge yourself in our project. I know that the research work is not easy for most of you. We had the tallest and biggest reactors running in the department; We 
had the most technical problems, which you know. I think that these must be from the trial of god. Thank you for sharing the trial with me together for the operation: Yongzhi, Binhe and Wei. Even for the batch experiments, it is difficult due to the large number of tests, new try of calculation and design. I can see that Grace, Agathi, and Rui suffered a lot, especially for Santtu. You know that the tough experiments, dirty materials, and unknown pressure. Well, the most painful thing is the writing and let's let it go. I really learned a lot and grew with you together, my friends.

Thank you for my Paranymphs Weishan and Yin, and I can imagine that we are going to have a nice graduation party. Now, Weishan (MoMo), you become No. 1 in Chinese community after my leaving. Congratulations, and I feel so released. Time flies and many things change. I still remember the first time we met, when you introduced that you were from Taiwan, and afterwards we rarely talked. Things start to change since more good Chinese students come to our department joining our research, and we communicate more. Our interaction became more and more since a landmark person came, and I know that all of you get it. It identifies that the Chinese strategies for study aboard are successful from this point. It does promote the commutation. Yin, I wish that you complete the thesis soon and get together with you wife soon. I know the feeling away from home, especially far away from home university. The darkness before dawn is deep, cold, lonely but should be short.

Jose Manuel and Vidal, thank you very much, my best friends. You impressed me how friendly Spanish people are, and how interesting and beautiful Spain is. You surprised me that how you like party and how many interesting games there are. I never have such fun after you leave, and miss you so much. Don't forget, come to China and let me show you around my hometown and good food.

Yingdi, Chen, Tianyi, Feng, you are my family in the Netherlands, thank god for sharing the same house with you. We are the best Dota2 team in B7. I would remember the DOTA night, the delicious food we prepare for the weekend, the Mahjong we played and the movies we watched together. I did not feel lonely when we are together. However, all go things must go to an end. There will never be such a chance to share a house with good friends like you. I hope that we often keep in touch and have parties if we have a chance to meet.

Thank you for all my friends living in the Netherlands. I can't count all of you, but in particular, Chen Zhang, Xu Cheng, Si Chen, Yuan He, Dong Peng, Ang Li, Jiao Long, Yueying Zhang, Guo Yu, Gang Wu, Qian Zhang, Lingmin Tian, Chen Sun, Lina Zhang, Jinfeng Peng, Jiawen Xiang, Mingtian Yao, Jinxin Wang, Shengle, Wei Qin, Yuang Zhang, Haizhen Mo, Jie Bai, Shengnan Xu, Hongming Zhang, Haoran Yang, Teng Li, Libo Niu, Yifan Yang.

Great credits to my family. To my wife, Xin, the dream started from you. To my son, now I can spend more time together with you. To my parents and parents in law, you give me the greatest support. 


\section{About the author}

Lei Zhang was born on $21^{\text {st }}$, 1983, in Harbin, China. In September 2005, he graduated from Engineering in Civil Engineering at Harbin Institute of Technology (HIT), China. From 2005 to 2007, he continued the master study. He started the

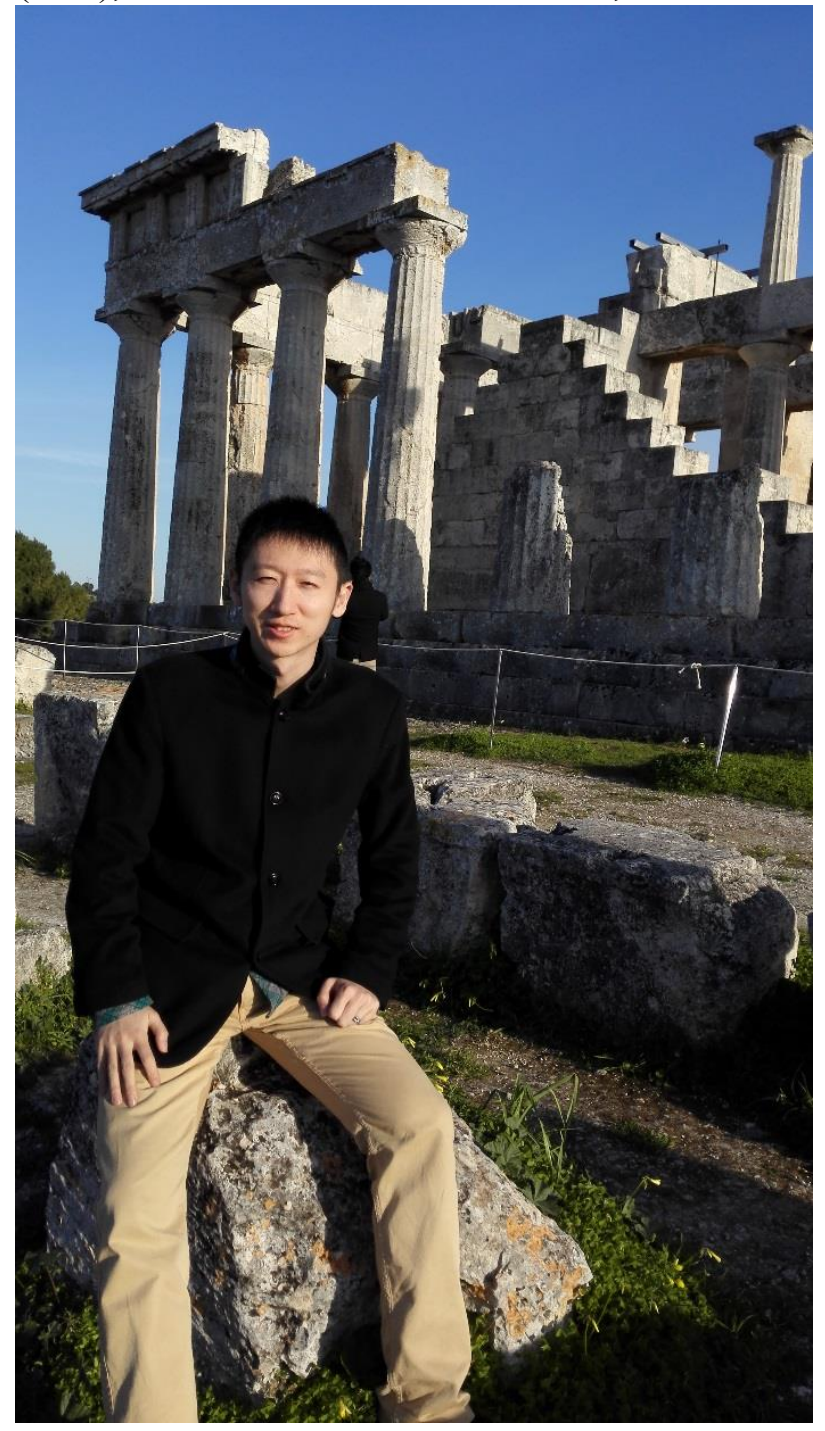
research career as a research assistant at home university. From 2009.09 to 2010.12, he got scholarship from China Scholarship Council to work as a research guest at Sub-department of Environmental Technology in Wageningen University (WUR) in the Netherlands, and continued the research work from 2011.01 to 2011.12 with scholarship from the department. From 2012.01 to 2012.12, he finished research work in HIT. In January 2013, he started the $\mathrm{PhD}$ project at Sub-department of Environmental technology in WUR, the Netherlands. From November 2016, he works at School of Mining and Petroleum Engineering, Alberta University, Canada as a postdoc working on the theme of anaerobic wastewater treatment. 


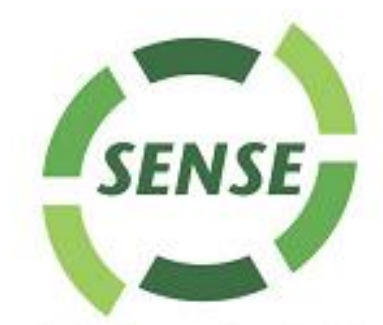

Netherlands Research School for the

Socio-Economic and Natural Sciences of the Environment

\section{I P L O M A}

For specialised PhD training

The Netherlands Research School for the Socio-Economic and Natural Sciences of the Environment

(SENSE) declares that

\section{Lei Zhang}

born on 21 February 1983 in Harbin, China

has successfully fulfilled all requirements of the

Educational Programme of SENSE.

Wageningen, 23 November 2016

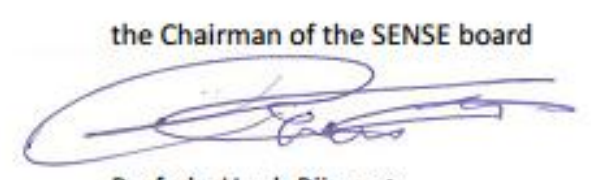

Prof. dr. Huub Rijnaarts the SENSE Director of Education

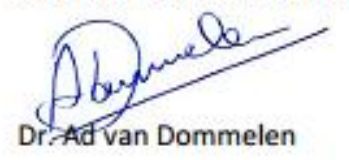

The SENSE Research School has been accredited by the Royal Netheriands Acaderny of Arts and Sciences (KNAW)

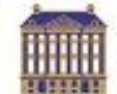

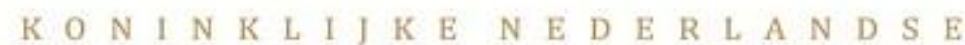

A K A D E M I E $V$ C A $N$ W 


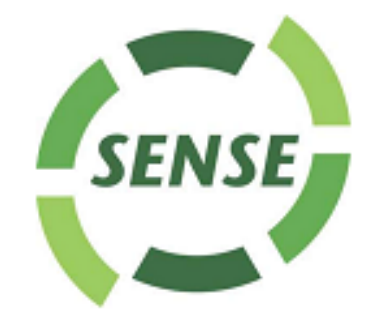

The SENSE Research School declares that Mr Lei Zhang has successfully fulfilled all requirements of the Educational PhD Programme of SENSE with a work load of $40.5 \mathrm{EC}$, including the following activities:

\section{SENSE PhD Courses}

- Environmental research in context (2013)

- Research in context activity: 'Preparing and creating Wikipedia pages on "A UASBdigester system: Option for anaerobic treatment of low temperature municipal wastewater" in English and Chinese' (2016)

\section{Other PhD and Advanced MSc Courses}

- Scientific writing, Wageningen University (2013)

- Reviewing a scientific paper, Wageningen University (2013)

- Effective behaviour in your professional surroundings, Wageningen University (2013)

- Writing grant proposals, Wageningen University (2014)

- Techniques for writing and presenting a scientific paper, Wageningen University (2014)

- Career orientation, Wageningen University (2015)

\section{Management and Didactic Skills Training}

- Member of the Wageningen University PhD Council (WPC) (2013-2015)

- Supervising four MSc theses (2013-2016)

\section{Oral Presentations}

- The effect of sludge recirculation rate on a UASB-digester treating domestic sewage at $15^{\circ} \mathrm{C}$, X Latin American Workshop and Symposium on Anaerobic Digestion (DAAL), 23-27 October 2011, Minas Gerais, Brazil

- Sludge tronsfer point of a UASB-digester system: key to efficient low temperature anaerobic sewage treatment. $13^{\text {th }}$ World Congress on Anaerobic Digestion: Recovering (bio) Resources for the World, 25-28 June 2013, Santiago de Compostela, Spain

\section{SENSE Coordinator PhD Education}


The research described in this thesis was financially supported by STOWA (Foundation for Applied Water Research), Paques BV, RVO (Netherlands Enterprise Agency), Hoogheemraadschap de Stichtse Rijnlanden, Hoogheemraadschap van Rijnland, Waterschapsbedrijf Limburg, Waterschap Drents Overijsselse Delta, Waterschap Rivierenland en Waternet, project number 432629.

Financial support from Wagningen University for printing this thesis is gratefully acknowledged.

Cover picture is provided by Xin Ma. 


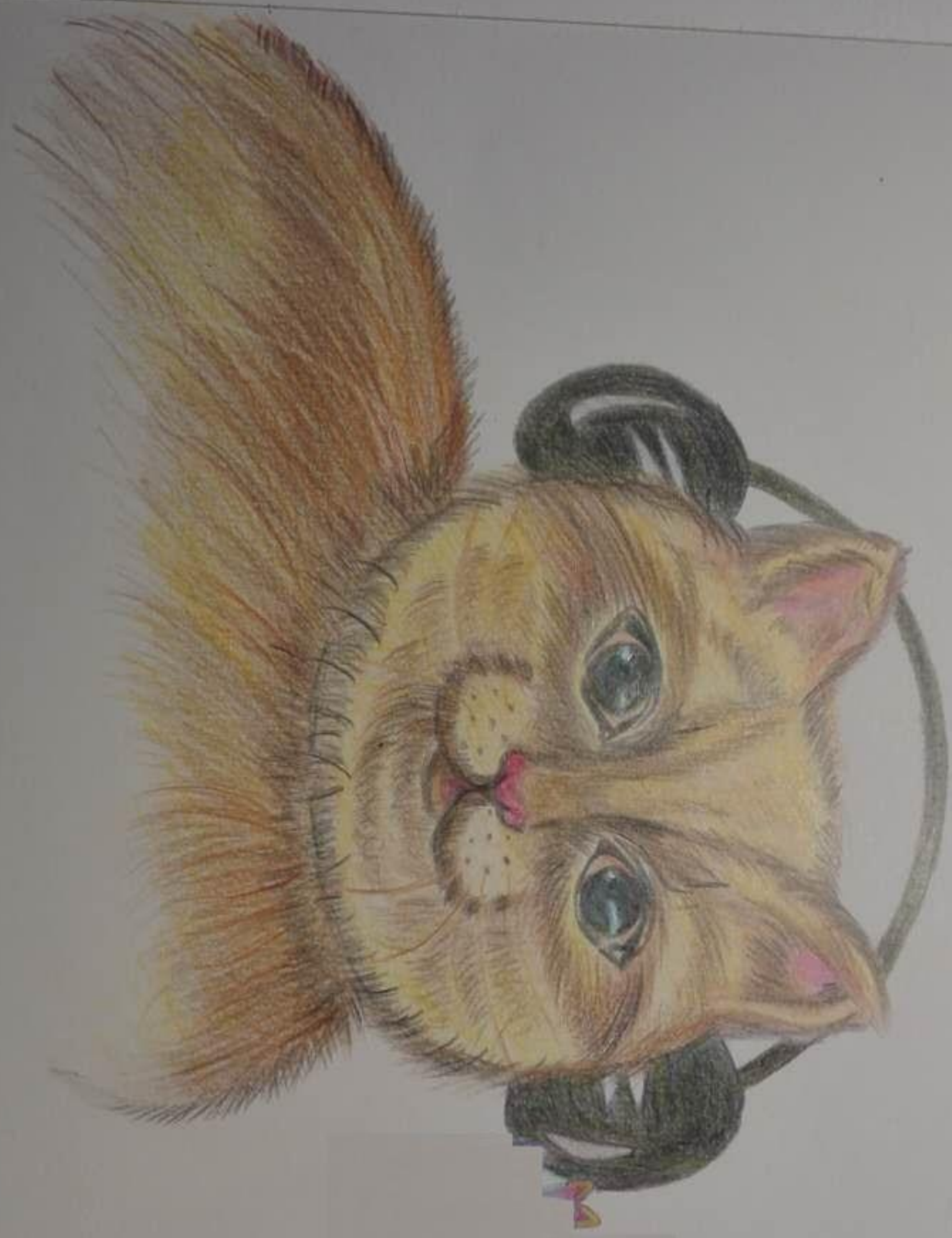

